RAUL JORGE DE PINHO CURRO

\title{
MERCOSUL: A MOEDA ÚNICA E SUAS CONSEQÜÊNCIAS NO COMÉRCIO INTERNACIONAL
}

\author{
Tese de Doutorado
}

Orientador: Professor Doutor Masato Ninomiya

Faculdade de Direito da Universidade de São Paulo

São Paulo 


\title{
MERCOSUL: A MOEDA ÚNICA E SUAS CONSEQÜÊNCIAS NO COMÉRCIO INTERNACIONAL
}

\author{
Tese apresentada à Faculdade de \\ Direito da Universidade de São Paulo \\ (USP) como requisito parcial para a \\ obtenção do título de Doutor em \\ Direito, sob a orientação do Professor \\ Doutor Masato Ninomiya.
}

Candidato: Raul Jorge de Pinho Curro

Faculdade de Direito da Universidade de São Paulo São Paulo 
Banca Examinadora 


\section{AGRADECIMENTOS}

Agradeço, em primeiro lugar, ao Professor Doutor Masato Ninomiya, nosso orientador, que, com paciência e abnegação, além de nos mostrar e corrigir os erros que cometemos ao longo do presente estudo, mostrou-nos novos rumos a seguir e, principalmente, ajudou-nos a melhor compreender e aplicar os princípios norteadores do Direito Internacional.

Aos colegas de trabalho Fábio, José Manoel, Ricardo, Otávio, Samuel Victor, Marina, Raquel, Daniel, Marcos, Galileu, Johan, Marco Antonio, Darwin, Marcelo, Felisberto, Margareth, Osmar, Ney, Flávia, Nelson, Idervânio, Luciana, Wannine, Euler, Luiz, Targino, Sergio, Rodrigo, Rita e Carlos Alberto, cujo apoio tornou menos difícil e árduo concluir o presente trabalho.

Aos nossos saudosos pais (in memoriam), cujo exemplo de vida sempre foi, e continua sendo, nossa fonte de inspiração e luta.

Aos queridos filhos Luís César, Carlos Augusto e Ana Cláudia, bem como à Sandra e aos adoráveis netos Linda e Luigi, pelo carinho de sempre.

Aos queridos amigos Emiliano, Emilio, Luiz Primolan, Paulo Ney, Rui Araújo, José Roberto, Luiz Augusto, Jorge e Willy, que foram fonte de estímulo e apoio.

E, por último, mas nem por isso menos importante, agradeço, do fundo do coração, a Maria Regina, por ter concordado em abrir mão de alguns dos melhores momentos que poderíamos ter desfrutado juntos, ao compreender que tal sacrifício foi necessário, a fim de que esta importante tarefa fosse concluída. A ela, a minha afeição e eterna gratidão. 


\section{SUMÁRIO}

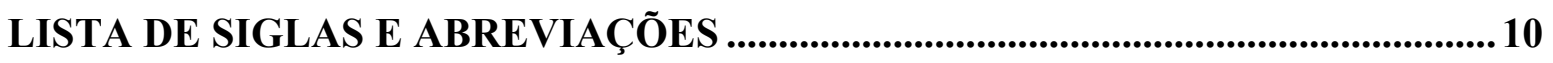

INTRODUÇÃ

CAPÍTULO I - A MOEDA..................................................................................... 17

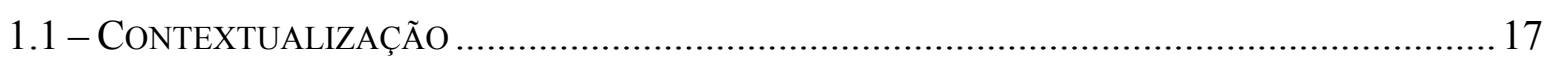

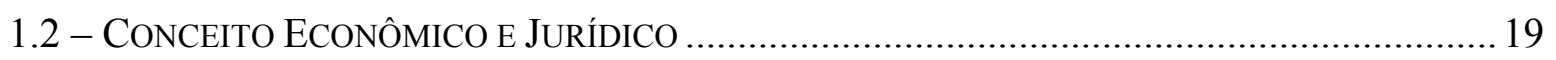

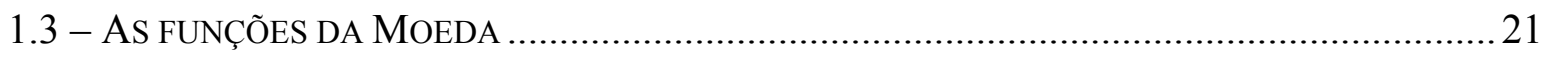

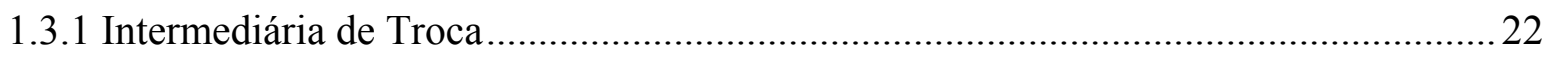

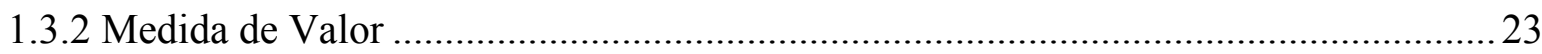

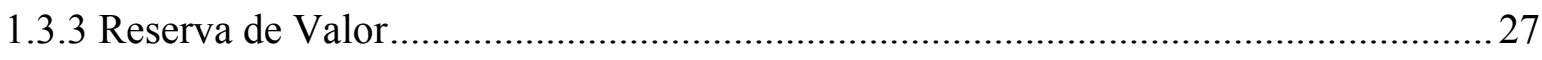

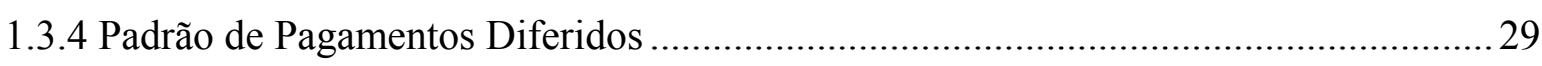

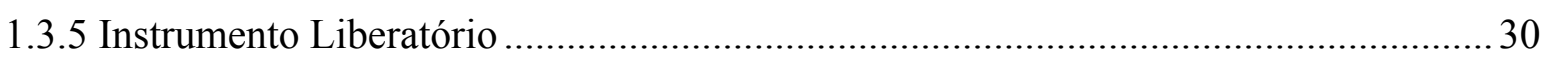

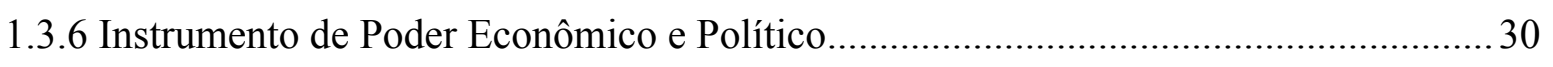

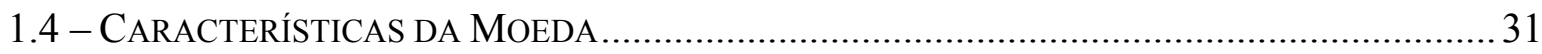

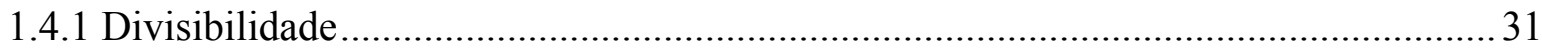

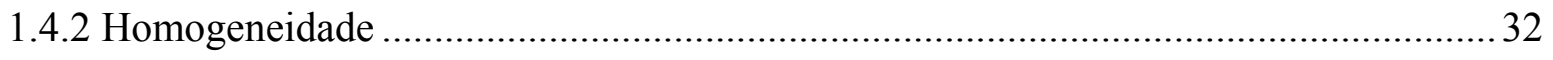

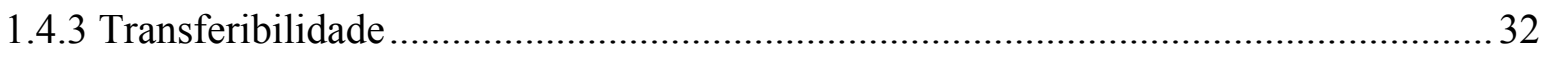

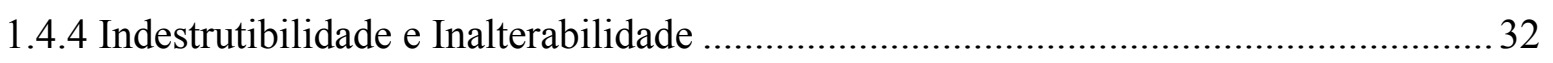

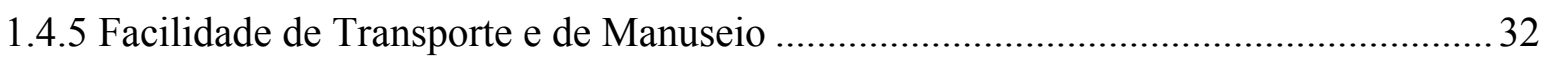

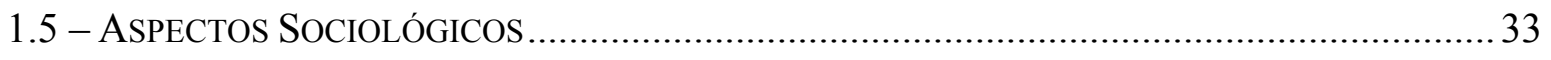

1.6 - Evolução Histórica dos Primeiros Subsistemas Monetários Existentes. O

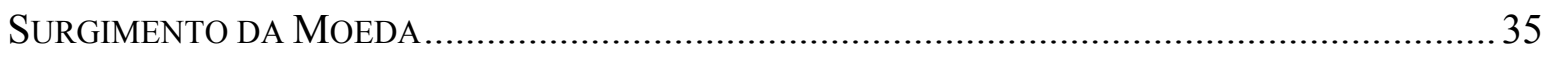

CAPÍTULO II - A MOEDA NO MUNDO .................................................................40 40

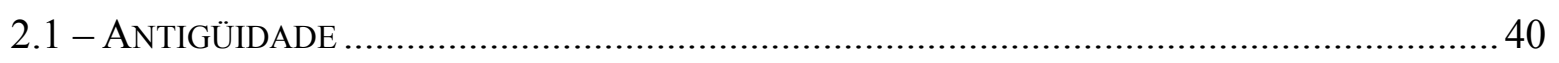

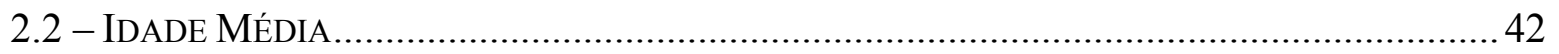

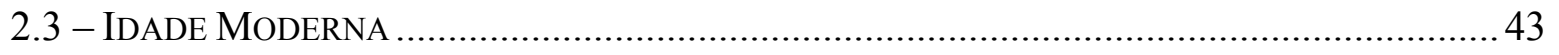

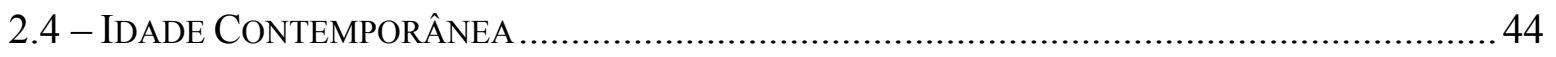

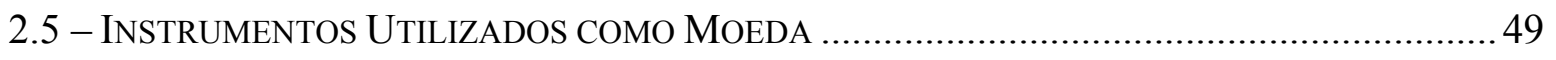

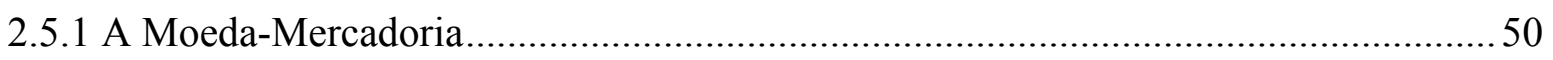

2.5.2 A Moeda Metálica .............................................................................................. 52 


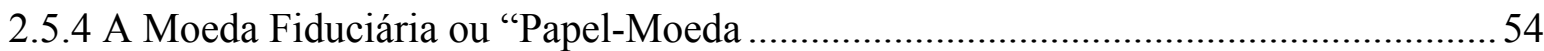

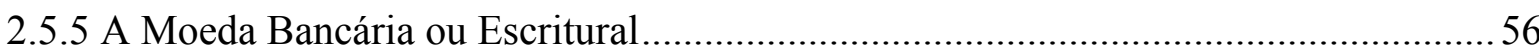

2.6 - O Sistema MonetÁrio InTERnACIONAL E SUA RELAÇÃo COM O OURO E AS MOEDAS

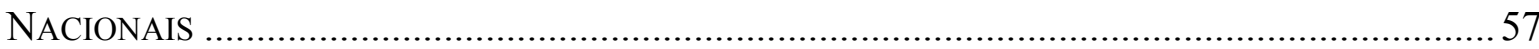

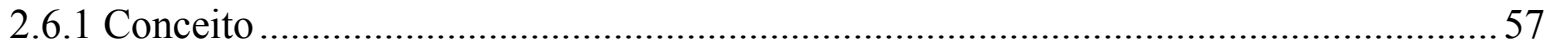

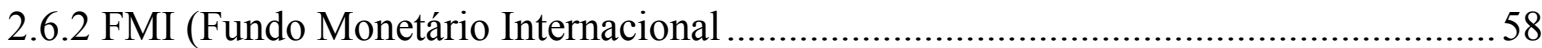

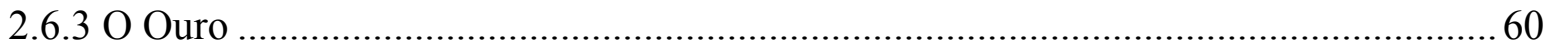

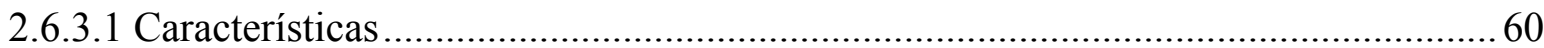

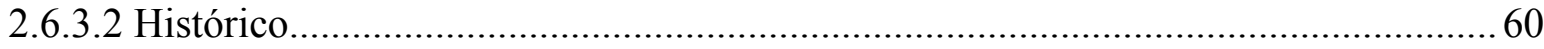

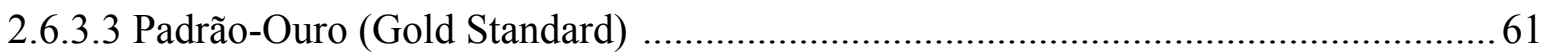

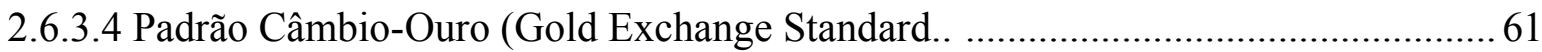

2.6.3.5 Circulação do Ouro nos Países Fundadores do Mercosul......................................... 62

CAPÍTULO III - A MOEDA NO BRASIL ......................................................................64

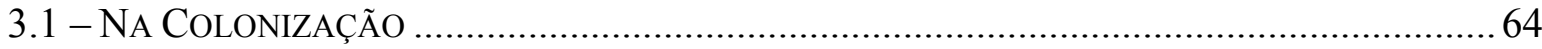

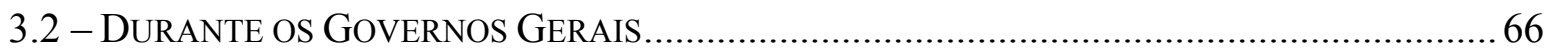

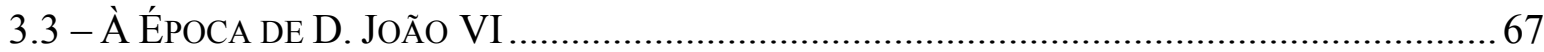

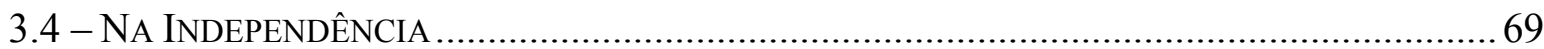

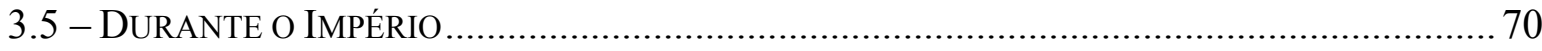

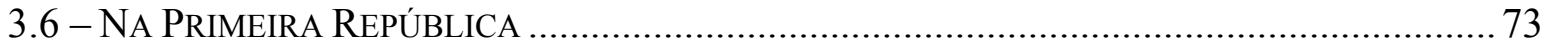

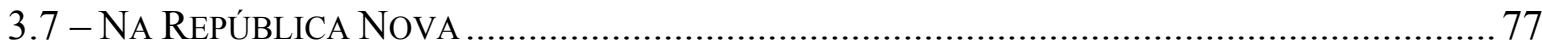

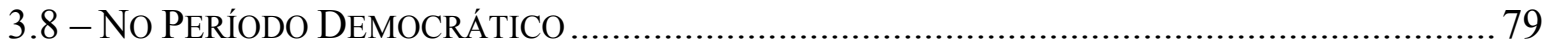

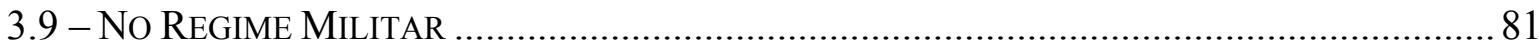

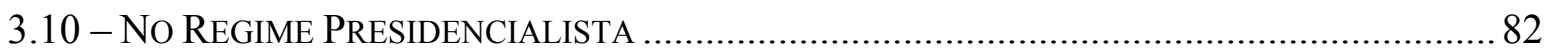

3.11 - REFORMAS MONETÁRIAS E OS PlANOS ECONÔMICOS ................................................. 86

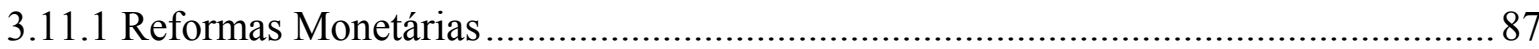

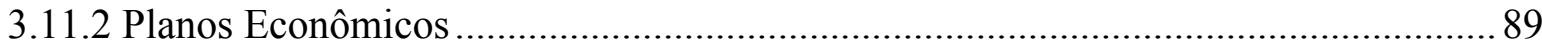

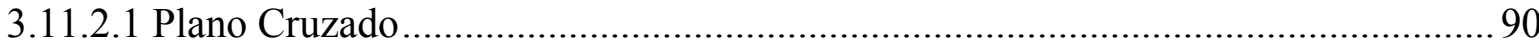

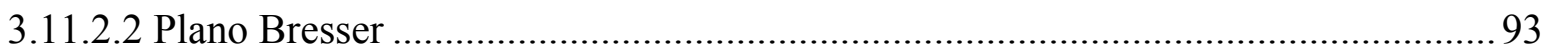

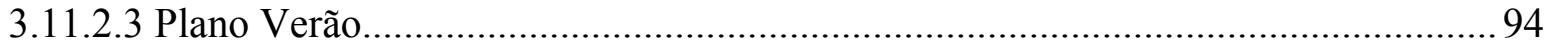

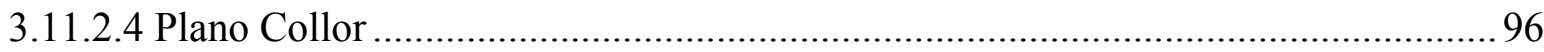

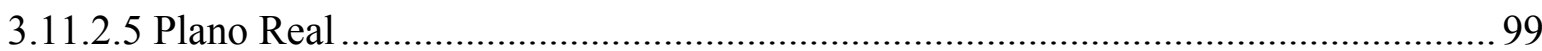

3.12 - O MERCADO DE CÂMBIO NO BRASIL......................................................................... 104 
CAPÍTULO IV - A EXPERIÊNCIA DA MOEDA ÚNICA NA UNIÃO EUROPÉIA

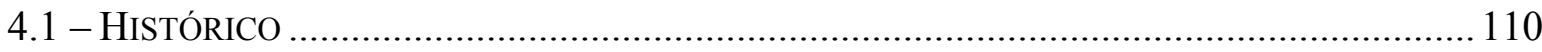

4.2 - O Tratado de MaAstricht e o Aprofundamento da IntegraÇão Via União EUROPÉIA 117

4.3 - ETAPAS E CRONOGRAMA DA IMPLANTAÇÃO DO EURO ............................................... 122

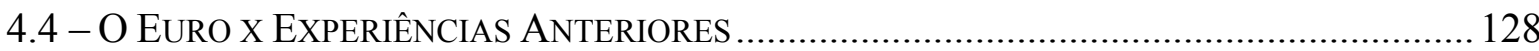

4.5 - RESISTÊNCIAS E DIFICULDADES NA IMPLANTAÇÃO DO EURO ….................................... 131

CAPÍTULO V - ANÁLISE DA POSSIBILIDADE DE ADOÇÃO DE UMA MOEDA

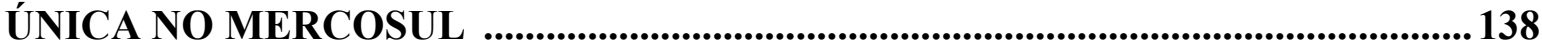

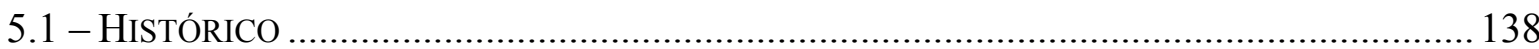

5.2 - A Possibilidade DE UMA Moeda ÂNCORA E A INFluÊNCIA DO Brasil NO

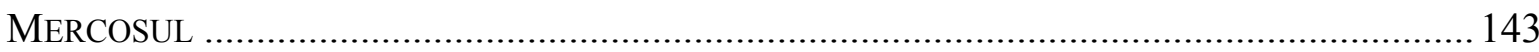

5.3 - A FleXIBILIZAÇÃo dA Soberania COM A AdoÇão DE UMA MoEdA ÚNICA .............. 145

CAPÍTULO VI - A BUSCA DA INTEGRAÇÃO NO MERCOSUL ............................. 151

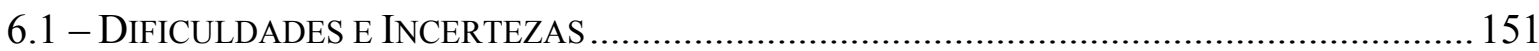

6.1.1 A Estrutura Institucional Minimalista do Mercosul e a Metodologia de Integração. 151

6.1.2 O Mercosul ainda é meramente uma União Aduaneira Imperfeita .......................... 155

6.1.3 A Irrealística Divisão Igualitária de Poder entre os Estados Partes do Mercosul...... 157

6.1.4 A Relação entre os Dois Principais Parceiros do Mercosul..................................... 160

6.1.5 O Fluxo Comercial no Mercosul Especialmente Centrado em Determinantes da

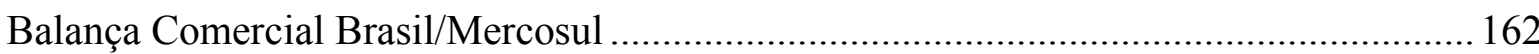

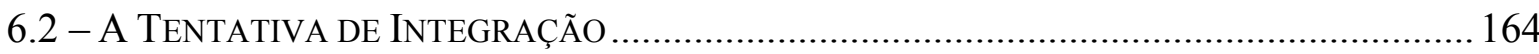

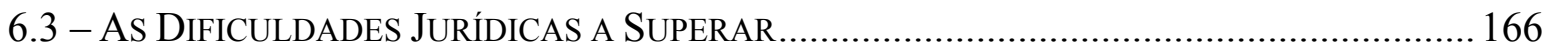

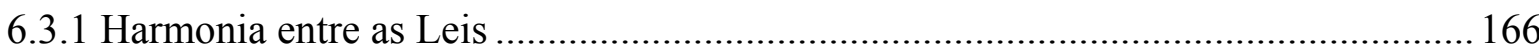

6.3.2 A Imprevisão Constitucional da Supranacionalidade .............................................. 168

6.3.3 A Necessária Continuidade da Segurança jurídica ................................................... 171

CAPÍTULO VII - PRESSUPOSTOS E CRITÉRIOS PARA A ADOÇÃO DE UMA MOEDA ÚNICA NO MERCOSUL .................................................................................... 172

7.1 - CONDIÇÕES PARA A IMPLEMENTAÇ̃̃O DE UMA ZONA MONETÁRIA ÓTIMA...................174

7.1.1 Harmonização das Legislações Nacionais - Direito Comprado no Mercosul............ 179 
7.1.2 Exercício Temporário de um Sistema de Taxas Cambiais com Limites de Oscilação. 185

7.1.3 Criação de um Banco Central Único: O Banco Central do Mercosul 187

7.2 - Análise Crítica das Vantagens e Desvantagens da Adoção de uma Moeda ÚNICA 190

7.2.1 Vantagens. 190

7.2.1.1 Maior Estabilidade a partir da Elaboração Conjunta de Políticas Econômicas ...... 190

7.2.1.2 Ganho de Credibilidade e Reputação para os Estados Partes e para o Mercosul ... 192

7.2.1.3 Menor Exposição a Choques Externos 192

7.2.1.4 Maior Poder de Negociação frente a Credores Externos e Organismos Multilaterais 193

7.2.1.5 Ganhos de Escala de Produção e Investimentos 194

7.2.1.6 Possibilidade de Inserção de Políticas de Diminuição das Disparidades entre Membros 195

7.2.2 Desvantagens 196

7.2.2.1 Perda de Parte da Soberania e Conseqüente Autonomia sobre Certas Políticas Governamentais

7.2.2.2 Altos Custos para a Transição Monetária ............................................................... 197

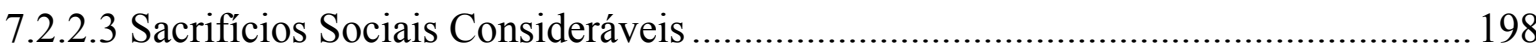

7.2.2.4 Precária Flexibilização da Legislação Trabalhista resultando em Aumento da Inflação e Diminuição dos Empregos 198

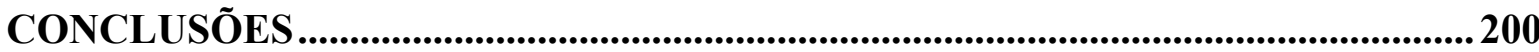

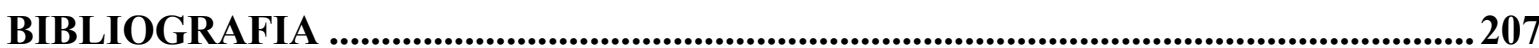

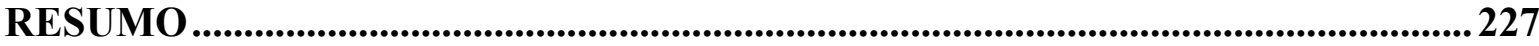

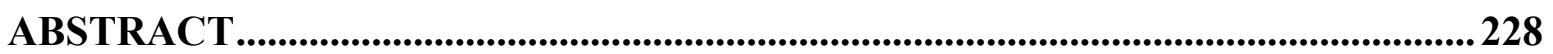

RÉSUMÉ 


\section{LISTA DE SIGLAS E ABREVIAÇÕES}

ALALC - Associação Latino-Americana de Livre Comércio

AMO - Área Monetária Ótima

BACEN - Banco Central do Brasil

BB - Banco do Brasil

BCE - Banco Central Europeu

BENELUX -Belgium (Bélgica), Netherlands (Holanda) e Luxembourg (Luxemburgo)

BCN - Bancos Centrais Nacionais

BID - Banco Interamericano de Desenvolvimento

BIRD - Banco Internacional para a Reconstrução e o Desenvolvimento

BNH - Banco Nacional da Habitação

BRIC - Conjunto de países: Brasil, Rússia, Índia e China

BTN - Bônus do Tesouro Nacional

CCM - Comissão de Comércio do Mercosul

CCR - Convênio de Pagamentos e Créditos Recíprocos

$\mathrm{CE}$ - Comunidade Européia

CECA - Comunidade Européia do Carvão e do Aço

CEE - Comunidade Econômica Européia

CEEA - Comunidade Européia de Energia Atômica (Euratom)

CMC - Conselho do Mercado Comum

CMN - Conselho Monetário Nacional

COREPER - Comitê de Representantes Permanentes

CPC - Comissão Parlamentar Conjunta

ECU - European Currency Unit (Unidade Monetária Européia)

EMU -Economic and Monetary Union

EMS - European Monetary System

EU - European Union

EUA - Estados Unidos da América

FCES - Foro Consultivo Econômico-Social

FED - Federal Reserve Bank

FGTS - Fundo de Garantia por Tempo de Serviço

FIPE - Fundação Instituto de Pesquisas Econômicas

FMI - Fundo Monetário Internacional

GMC - Grupo Mercado Comum

IBGE - Instituto Brasileiro de Geografia e Estatística

IGP-M - Índice Geral de Preços do Mercado

IME - Instituto Monetário Europeu

INCC - Índice Nacional da Construção Civil

IPA - Indíce de Preços no Atacado

IPC - Índice de Preços ao Consumidor

MTC - Mecanismo de Taxas de Câmbio

MERCOSUL - Mercado Comum do Sul

MDIC - Ministério do Desenvolvimento, Indústria e Comércio Exterior

NCM - Nomenclatura Comum do Mercosul 
OCA - Optimum Currency Area

OMC - Organização Mundial do Comércio

PEC - Pacto de Estabilidade e Crescimento

PIB - Produto Interno Bruto

POP - Protocolo de Ouro Preto

PROER - Programa de Estímulo à Reestruturação e ao Fortalecimento do Sistema

Financeiro Nacional

SAM - Secretaria Administrativa do Mercosul

SEBC - Sistema Europeu de Bancos Centrais

SECEX - Secretaria de Comércio Exterior (órgão integrante do MDIC)

SFN- Sistema Financeiro Nacional

SME - Sistema Monetário Europeu

SMI - Sistema Monetário Internacional

SUMOC - Superintendência da Moeda e do Crédito

TAs - Tratado de Assunção

TEC - Tarifa Externa Comum

UE - União Européia

UEM - União Econômica e Monetária

UEP - União Européia de Pagamentos

UME - União Monetária Européia

UFIR - Unidade Fiscal de Referência

URP - Unidade de Referência de Preços

URV - Unidade Real de Valor 


\section{INTRODUÇÃO}

À primeira vista, parece que o fenômeno da moeda única tende, de forma cada vez mais acelerada e inexorável, a se tornar um processo irreversível no âmbito mundial, a partir do aparente sucesso que o euro vem obtendo como unidade monetária na União Européia.

Dizemos aparente sucesso, porque, em nossa opinião, ainda é prematuro poder afirmar, com absoluta certeza, que o euro, seja, realmente, um exemplo de união monetária bem sucedida, haja vista a sua impotência ou incapacidade para enfrentar a recente crise mundial, cujos efeitos mais nefastos estão, justamente, sendo sentidos pela Europa, aí incluída a denominada área do euro.

Diante disso, então, seria razoável admitir que o Mercosul (Mercado Comum do Sul) poderia ser um dos próximos alvos a enfrentar a experiência de uma moeda única, a exemplo da União Européia?

Primeiramente, é importante relembrar que a coexistência do internacionalismo do comércio internacional e do nacionalismo das moedas sempre implicou, inevitavelmente, como conseqüência natural, a necessidade de se criarem mercados de câmbio para atender às respectivas conversões das moedas estrangeiras para a respectiva moeda nacional, e sob a égide de um arcabouço jurídico complexo, especialmente no caso do Brasil. Evidentemente, se num determinado momento, talvez jamais atingível, tivermos uma única moeda circulando por todos os países do mundo, os mercados de câmbio serão totalmente inúteis.

É, pois, bastante intuitivo imaginarmos o impacto, tanto na dimensão jurídica como na econômica, que essa mudança - passagem do advento da multiplicidade de moedas nacionais, atualmente existentes, para uma única moeda -, traria, não apenas no que tange ao comércio de divisas e nas transações envolvendo o comércio exterior, como também no mercado de trabalho.

Note-se que, ao longo desta década, nada menos que quinze moedas deixaram de existir na União Européia (constituída, até o final de 2008, de 27 Estados-Membros), sendo 
certo que outras irão desaparecer nesse mesmo bloco, na medida em que outros países europeus atendam aos critérios de convergência estabelecidos e adiram à moeda única.

E o que poderá acontecer no comércio internacional em razão dessa mudança? Será que a adoção de uma moeda única nos blocos econômicos existentes e a se formarem, virá a facilitar as transações comerciais de mercadorias e serviços, ou, ao contrário, trará mais prejuízos que benefícios?

Dentro desse contexto, o nosso trabalho terá, como foco, a análise e o debate quanto à (in)viabilidade da adoção de uma moeda única no âmbito do Mercosul e suas conseqüências no comércio internacional, com destaque para os seus aspectos jurídicos e o contexto político e econômico atual.

O objetivo central desse trabalho é, portanto, apresentar uma análise crítica, com destaque para o enfoque jurídico, quanto à impossibilidade da união monetária no âmbito do Mercosul, diversamente do que ocorreu no seio da União Européia, com a introdução do euro em 1999, na forma escritural, e a partir de 2002, em sentido amplo, com o curso habitual de todas as formas de circulação da moeda (escritural, cédula e moeda metálica). Ao mesmo tempo, examinam-se as conseqüências para o comércio internacional relativamente à adoção ou não da união monetária no âmbito do Mercosul.

Cumpre-nos antecipar, desde já, que, em nossa opinião, a adoção de uma moeda única no Mercosul, no presente contexto, nos parece inviável, como demonstraremos ao longo da fundamentação exposta nesse estudo. Ressaltamos que a nossa posição nesse sentido é sustentada, não só porque constatamos que é precoce utilizar como espelho para o Mercosul o modelo europeu - que, a nosso ver, e a despeito do aparente sucesso até então alcançado, ainda está muito longe de se consolidar e comprovar a eficácia da união monetária implementada -, mas ainda porque as condições jurídicas, políticas, econômicas, socioculturais e históricas do Mercosul são completamente distintas das ocorridas no continente europeu.

Para fundamentar nossas conclusões, o presente trabalho leva em conta a análise e os fundamentos expostos em doutrina dos mais renomados estudiosos do tema, aliada à nossa própria experiência no mercado de câmbio (no Brasil e no exterior) ao longo de cerca de 40 anos.

Um outro aspecto que mereceu nossa atenção foi no tocante à delimitação deste estudo, isto é, no tempo e no espaço, sob pena de, em deixando de fazê-lo, tornar-se impossível concluí-lo, ante a amplitude do tema. Assim, temporalmente, no tocante ao 
estudo da moeda em geral, estendemos nossa análise, embora de forma o mais sintética e resumidamente possível, desde os primórdios de que se tem notícia do aparecimento da moeda metálica (século VII a.C.) até o momento atual. Quanto ao histórico do Mercosul, analisamos o período que vai desde a constituição do bloco (Tratado de Assunção), em 1991, até o final do ano 2008. Em termos espaciais, percorremos os cenários geográficos, ao redor do mundo, que nos pareceram mais relevantes, com destaque especial para o espaço abrangido pelos quatro países fundadores do Mercosul: Argentina, Brasil, Paraguai e Uruguai.

Será possível observar, nesse particular, que as histórias da moeda e do direito guardam muitos pontos em comum. Ou seja, tanto a moeda como o direito sempre permearam e ainda permeiam todas as grandes mudanças históricas pelas quais a humanidade vem passando. Realmente, ambos, dentro de sua esfera específica de atuação, visam a facilitar as multifacetadas transações, cujo número cresce exponencialmente, no mundo dos negócios nacionais e internacionais, além de acelerar as soluções dos muitos conflitos que acabam por acontecer entre os agentes econômicos.

Assim, a moeda acelera as trocas de mercadorias e serviços, facilitando o comércio entre pessoas, países e blocos econômicos. O direito, a seu turno, acelera os procedimentos envolvidos numa lide, fazendo que se encurte o tempo de sua duração e, dessa forma, fazendo justiça mais efetivamente, pois a pior injustiça é a demora em se resolver uma pendência judicial. Infelizmente, ocorre que, com freqüência, o direito resolve a lide, mas o conflito permanece.

Observamos, então, que, de certa forma, tanto o direito como a moeda se revestem, pelo menos, de uma característica comum: a luta contra o tempo, cada um dentro de sua esfera de atuação, mas visando sempre o interesse da sociedade.

Mas há ainda um outro fato a ser observado: o direito é o precursor de efetividade e eficácia para a existência, quer de uma moeda nacional, em relação a um determinado país, quer de uma moeda única, no âmbito de um determinado bloco econômico.

Nossas conclusões quanto à inviabilidade monetária no Mercosul, objeto central desta pesquisa, passam essencialmente pelas seguintes razões: (i) o modelo europeu ainda está longe de ser considerado um sucesso, pois a zona monetária do euro foi fortemente impactada pela recente crise mundial (originada a partir de 2007, nos Estados Unidos da América, com o assim denominado risco "subprime"); e (ii) ausência, no âmbito do Mercosul, dos pressupostos e critérios observados na união monetária européia, tais como 
a homogeneização das legislações nacionais dos países componentes do bloco, experiência temporária de um sistema de taxas cambiais com limites de oscilação pré-fixados, criação de um Banco Central único, e, por fim, a adoção de uma Constituição supranacional, a fim de embasar a existência de uma efetiva união política.

O trabalho está dividido em sete capítulos.

Preliminarmente, no capítulo I, abordaremos o conceito jurídico e econômico da moeda. Analisar-se-ão, aqui, as funções e características da Moeda, de uma maneira geral, com destaque para o entendimento de Tullio Ascarelli, Keynes e Nussbaum. Em apertada síntese, destacar-se-ão, ainda, alguns aspectos sociológicos da moeda, a evolução histórica dos primeiros subsistemas, além de um breve panorama da origem da moeda, que prenunciou a sua transmutação de moeda-mercadoria para moeda-metal e, em seguida para moeda-papel, e, assim, sucessivamente, passando para papel-moeda, e, finalmente, atingir a atual moeda escritural, também conhecida por moeda bancária ou invisível.

No Capítulo II, ao tratarmos da moeda no mundo, far-se-á uma rápida incursão histórica até à Antigüidade Clássica, onde será ressaltada a evolução da moeda até a Idade Contemporânea, passando por diversos subsistemas monetários mais complexos e elaborados, principalmente a partir da Primeira e Segunda Guerras Mundiais, que alteraram, indiscutivelmente, as relações entre os Estados e empresas multilaterais, quando a moeda passou a ser, notadamente, o principal instrumento a mediar as relações socioeconômicas entre os povos. Abordar-se-ão, ainda, os vários instrumentos utilizados como moeda, a partir da necessidade da construção de sistemas e subsistemas monetários estruturados em pilares jurídicos e econômicos, com o fim de assegurar a manutenção das negociações às partes envolvidas. O sistema monetário internacional será destacado, de forma a enfocar o papel do FMI (Fundo Monetário Internacional), criado na Conferência de Bretton Woods, bem como o ouro (considerada uma "relíquia bárbara" para alguns) ao longo de seu papel como padrão monetário, além serem mencionadas as condições em que circula nos Estados Partes do Mercosul.

No Capítulo III, será feita uma avaliação da evolução da moeda no Brasil, desde o período colonial até a atualidade, ressaltando as reformas monetárias, os planos econômicos, bem como o regime jurídico da moeda brasileira. O mercado de câmbio será objeto de análise, ao final do capítulo, com especial atenção no que toca à realidade brasileira. 
No Capítulo IV, será analisada a experiência da moeda única na União Européia, abordando-se, especificamente, o Tratado de Maastricht, o cronograma de implantação da moeda única, as experiências anteriores, as resistências e dificuldades enfrentadas na sua implantação.

O Capítulo V, por sua vez, já adentra a questão central desta tese quando se discute a (im)possibilidade de adoção de moeda única no Mercosul, com destaque para a influência do Brasil, inclusive quanto ao eventual uso do real como moeda-âncora, bem como a resistência que os Estados Partes fazem à perda de soberania, ainda que parcial, caso fosse adotada a moeda única .

O Capítulo VI analisará e avaliará as dificuldades, principalmente nos seus aspectos jurídicos, que os países do Mercosul enfrentarão para atingir uma integração regional, com especial destaque para os tratados e sua inserção nos ordenamentos nacionais.

No último Capítulo, serão apreciados os pressupostos e critérios que seriam indispensáveis para a adoção da moeda única no Mercosul, especificamente sob o aspecto jurídico, fazendo-se um paralelo com o longo e não menos difícil caminho seguido pela União Européia.

Nas Conclusões, diante de tudo que será exposto e debatido, defenderemos a nossa proposta, previamente anunciada, quanto à inviabilidade de adoção de uma moeda única no Mercosul, bem como as conseqüências dessa medida no comércio internacional.

Cabe-nos, por fim, alertar que, por ocasião da apresentação do presente estudo, provavelmente outros trabalhos, mais bem elaborados e com maior brilho, versando sobre algumas (ou até mesmo a totalidade) das questões aqui ventiladas, já tenham sido examinados e/ou publicados. 


\section{CAPÍTULO I}

\section{A MOEDA}

\section{2 - Contextualização}

Desde o seu surgimento ${ }^{1}$, a moeda constituiu-se como meio de troca, primeiro exclusivamente no âmbito nacional para, posteriormente, expandir-se ao internacional. $\mathrm{Na}$ Idade Contemporânea, através de sua concretização, adquiriu caráter financeiro, comercial e/ou monetário. No sentido financeiro, a troca ocorre entre certa quantidade de moeda e um ativo financeiro, de forma a configurar uma compra ou uma venda de títulos de propriedade ou de crédito; no sentido comercial, visualiza-se a troca da moeda por um bem ou serviço; já no sentido monetário, observa-se a troca de uma moeda por outra moeda ${ }^{2}$.

As relações econômicas internacionais empreendidas no século XXI, cujo processo de regulamentação segue a lógica do mercado, desencadeiam suas negociações e interações pecuniárias entre os indivíduos por meio da moeda, método instrumental capaz de coordenar o cenário econômico e social, seja sob a interferência exclusiva das regras de mercado, seja sob a ingerência do Estado na economia, ou até mesmo, sob a influência de ambos, mercado e Estado.

Nesse sentido, para cumprir o seu papel, a moeda desempenha algumas funções de amplo alcance na ordem econômica: (i) intermediária de troca; (ii) medida de valor; (iii) reserva de valor; (iv) padrão de pagamentos diferidos; (v) instrumento liberatório; e, (vi) instrumento de poder econômico e social ${ }^{3}$. Ao exercer essas funções, a moeda preserva e exercita sua função institucional e contribui para a coesão das ordens social e monetária.

\footnotetext{
1 “A moeda é uma invenção social que vem de muito longe na história da humanidade e dela achamos vestígios na maioria das sociedades, não importando sua forma de constituição e de organização, sejam elas associadas ou não a um Estado." THÉRET, Bruno. Os três estados da moeda. Abordagem interdisciplinar do fato monetário economia e sociedade, Campinas, vol. 17, $\mathrm{n}^{\circ} 1$ (32), abr. 2008, p. 2.

${ }^{2}$ DINH, Nguyen Quoc; DAILLIER, Patrick; PELLET, Alain. Direito internacional público. Tradução do original intitulado Droit international public. 7. édition. Lisboa: Fundação Calouste Gulbenkian, 2003, p. 1.095 .

3 "Fruto de uma longa evolução sociológica, a moeda cumpre uma infinidade de papéis na economia. Os economistas usualmente classificam esses papéis em quatro grandes categorias: unidade de conta; meio de troca; reserva de valor e liquidez." OLIVEIRA, Marcos. Moeda, juros e instituições financeiras: regime
} 
Observamos, assim, a influência da moeda nas relações de caráter econômico, em âmbito interno e internacional, desempenhadas por um Estado, e o seu imediato reflexo no padrão social e cultural da população nacional. Ilustração disso pode ser encontrada na esfera jurídica, onde a relação entre o Estado e a moeda assume um significado peculiar, na medida em que o direito constitucionalmente reconhece a relação de complementaridade entre a ordem monetária e a ordem jurídica ${ }^{4}$.

Nesse sentido, importante ressaltar que é a regulação jurídica da moeda que possibilita uma harmonização entre o poder estatal de controle da moeda e os desígnios e aspirações de uma sociedade livre. Segundo FRIEDMAN:

O problema é estabelecer acordos institucionais que permitirão ao governo ter responsabilidade pela moeda, e, ao mesmo tempo, limitar o poder assim dado ao governo e prevenir o uso deste poder quando tende a enfraquecer ao invés de fortalecer uma sociedade livre ${ }^{5}$. (tradução livre)

No entanto, apesar da significativa influência exercida pelo Estado na manutenção das relações monetárias, a eficácia das normas monetárias e a utilização da moeda apenas encontram amparo a partir da aceitação e da confiança depositadas nela pela sociedade. Somente o preenchimento do requisito da aceitação social a manutenção das trocas internas e internacionais garante e preserva a estabilidade do sistema monetário do país ${ }^{6}$. A moeda extravasa o âmbito jurídico ${ }^{7}$.

BUITONI acompanha a idéia ao avaliar a execução e planejamento dos Planos de Estabilização Econômica no Brasil, sentindo-se seguro ao final de sua análise para afirmar que:

1. A moeda é um símbolo de grande significação para a economia e para o direito sendo que sua regulamentação jurídica deve respeitar sua função no mercado; 2 . A eficiência da moeda reside na sua interação qualitativa

\footnotetext{
jurídico. Rio de Janeiro: Forense, 2006, p. 122.

${ }^{4}$ CORTEZ, Tiago Machado. Moeda, estado e direito. O papel do Estado na ordem monetária e seu controle. São Paulo: EDUSP, 2004. Tese - USP, São Paulo, 2004, p. 4.

5 The problem is to establish institutional arrangements that will enable government to exercise responsibility for money, yet at the same time, limit the power thereby given to government and prevent this power from being used in ways that will tend to weaken rather than strengthen a free society. FRIEDMAN, Milton. Capitalism and Freedom. Chicago: University of Chicago Press. 2002, p. 39.

${ }^{6}$ CORTEZ, Tiago Machado (2004). Op. cit., p. 4.

${ }^{7}$ Há, no entanto, no universo do Direito uma crença generalizada de que a moeda é uma criação do Estado e de que a sua aceitação por ele decorre da autoridade legal dos instrumentos monetários, porque esses legitimam a livre circulação da moeda, conferindo-lhe autoridade de meio de troca reconhecido pelo próprio ordenamento jurídico estatal.
} 
com a realidade econômica e não, isoladamente, na sua expressão jurídica; 3. Planos de Estabilização Econômica devem levar em conta fatores racionais e também acasos, pois o controle da inflação não se dá unicamente pela imposição de normas jurídicas; 4. É possível a intervenção do Estado na ordem econômica para combater a inflação, devendo o Estado atuar dentro dos princípios constitucionais vigentes ${ }^{8}$.

Deve-se, na verdade, entender que a moeda contemporânea foi construída juridicamente sem significar com isso que ela deva a sua existência ao Direito. Enquanto instituição social, a moeda é o resultado da ação de indivíduos que estabelecem relações econômicas baseadas na troca de mercadorias. MENGER ${ }^{9}$, nesse sentido, afirma somente ser verdadeiramente possível entender a origem da moeda caso seja considerada como uma instituição social, como o resultado espontâneo, o produto não planejado dos esforços especificamente individuais dos membros da sociedade.

\section{2 - Conceito Econômico e Jurídico}

Não é tarefa fácil definir o que vem a ser a moeda, sem correr o risco de incidir em suas funções, ou mesmo na caracterização das várias espécies ou modalidades de moedas em circulação na economia. Assim, para bem compreender o papel desempenhado por ela, é de suma importância investigar a sua natureza e a forma dos mercados em que é utilizada.

A "aceitabilidade" por parte da sociedade representa um dos fatores essenciais para a sua existência e circulação, motivo pelo qual o cheque não é considerado uma moeda. A aceitabilidade do cheque é limitada, havendo, inclusive, estabelecimentos comerciais que se recusam a recebê-lo como forma de pagamento.

Segundo SANT'ANA ${ }^{10}$, a moeda corresponde a um conjunto de ativos financeiros, como, por exemplo, o papel-moeda, os depósitos bancários, os cheques de viagem, e outros, devendo, no entanto, apresentar uma característica especial que a diferencie de tais ativos. De acordo com o autor, a moeda, como todo ativo, possibilita a obtenção de recursos, mas, distintamente dos ativos, pode ser utilizada para as transações de compra e venda, como meio de pagamento.

\footnotetext{
${ }^{8}$ BUITONI, Ademir. Moeda, Inflação e Planos de Estabilização Econômica no Brasil. Revista dos Tribunais, vol. 713, ano 84, mar. 1995, p. 277.

${ }^{9}$ MENGER, Karl. On the origin of money. In: The economic journal, vol. 2, nº 6, June, 1982, p. 239-255.

${ }^{10}$ SANT'ANA, José Antonio. Economia monetária: a moeda em uma economia globalizada. Brasília: Universidade de Brasília, 1997, p. 12.
} 
Percebe-se que, em regra, a moeda é classificada pelos economistas de acordo com a sua liquidez, ou seja, de acordo com a possibilidade de conversão do ativo financeiro em dinheiro, sem qualquer perda do valor inicial. Assim, a moeda pode receber inúmeras denominações, como "M1", "M2", "M3" etc., baseando-se em seu grau de liquidez. No entanto, quando a moeda atinge liquidez absoluta, é em geral conceituada como a soma das moedas metálicas e do papel-moeda em poder do público, acrescida dos depósitos à vista nos bancos ${ }^{11}$.

No que se refere ao conceito jurídico da moeda, tem-se que este guarda uma estreita vinculação com os aspectos e considerações de natureza econômica, concernentes às funções da moeda e suas características ${ }^{12}$. O regime legal deve orientar-se de modo a prover uma adequada realização das funções e um cabal reconhecimento das condições idôneas a esse fim. Deve, pois, destacar claramente quais são os bens que o Estado reconhece como moeda outorgando-lhes tal caráter ${ }^{13}$.

PALLARES afirmava que no ordenamento jurídico a moeda é um fragmento de metal cunhado com o selo oficial do Estado para garantir sua forma, peso, legalidade e cujo poder liberatório ou emprego no pagamento de dívidas é obrigatório ${ }^{14}$.

O Direito Positivo contém uma série de dispositivos referindo-se à moeda através da utilização de diferentes termos, entre os quais se pode destacar, pela freqüência do emprego, "soma”, “quantidade”, “numerário", "valor” e o próprio termo "dinheiro". O uso dessas diferentes terminologias empregadas todas como sinônimo de moeda obedecem, em considerável medida, tanto às diversas épocas em que foram expedidas as respectivas disposições como à terminologia empregada usualmente nas operações a que os textos normativos se referem ${ }^{15}$.

A atividade empresarial gera moeda para utilização nas relações de mercado, constituindo, assim, o parâmetro do sistema ao fornecer-lhe a unidade e, ao mesmo tempo, é elemento do sistema que regula sua disciplina, pois permite que se exercitem os direitos

\footnotetext{
${ }^{11}$ SANT'ANA, José Antonio (1997). Op. cit., p. 12.

12 "Para desempenhar suas funções, as moedas devem apresentar algumas características que são essenciais. Características físicas e econômicas são necessárias ao desempenho das funções meio de troca, reserva de valor, unidade de conta e pagamentos diferidos. (...) Quando uma moeda possui as características físicas e econômicas que são imprescindíveis e essenciais (tal como denotado), pode-se dizer que ela está apta e que está habilitada a desempenhar as suas funções." GREMAUD, Amaury Patrick; VASCONCELLOS, Marco Antonio Sandoval de; TONETO JR., Rudinei. Economia Brasileira Contemporânea. 4. ed. São Paulo: Atlas, 2002, p. 617 e ss.

13 MARTINEZ, Francisco. El sistema monetário mexicano, p. 188. Disponível em: $<$ http://www.juridicas.unam.mx/publica/librev/rev/jurid/cont/16/pr/pr13.pdf >. Acesso em: 5 dez. 2008.

${ }^{14}$ PALLARES, Jacinto. El bimetalismo. Foro de México. $n^{\circ} 30,1^{\circ}$ set. 1955, p. 66.

${ }^{15}$ MARTINEZ. Op. cit., p. 189.
} 
em qualquer quadrante da sociedade, gerando liquidez e, com isso, permitindo exercitar todos os direitos subjetivos individuais. Por outro lado, afirma PALLARES ${ }^{16}$ que o crédito financeiro de moeda, prestação e contraprestação se cumprem com bens de mesma natureza, e isso distingue o negócio de crédito bancário do crédito comercial, porquanto neste há apenas o diferimento no pagamento.

O Estado tem competências, que não são prerrogativas, mas que definem deveres ${ }^{17}$. Entre esses deveres, está o de controlar o fluxo e manter o valor da moeda. Todas as decisões nesse sentido, inclusive, devem ser pautadas pelos princípios constitucionais. Ora, se dentre as funções que a moeda exerce, estiver a função de medida de valor, isto é, constituir reserva de valor, razão pela qual eram usados metais preciosos e daí passando-se para a progressiva substituição por recibos (notas de bancos), clara fica a necessidade de o Estado intervir em seu controle quando levado em conta o como a realidade econômica seria caso não trabalhasse nesse sentido, e o como deve ser, o que é buscado justamente através dessa regulação.

\section{3 - Funções da Moeda}

Dentre as funções desempenhadas pela moeda, desde o seu surgimento até os dias atuais, de acordo, entre outros, com LOPES e ROSSETTI ${ }^{18}$, merecem destaque: (i) de intermediária de troca; (ii) medida de valor; (iii) reserva de valor; (iv) padrão de pagamento diferido; (v) instrumento liberatório; e, (vi) instrumento de poder econômico e social.

\footnotetext{
${ }^{16}$ PALLARES, Jacinto. Op. cit., p. 66.

17 "É aconselhável chegarmos, desde logo, à compreensão daquilo que se entende por moeda, quanto às suas funções e às suas características. E sem abdicar, evidentemente, de promover a devida relação que há entre tais entendimento e conceituação e o papel que o Estado representa na política monetária (...)".ROBERTSON, Sir Dennis. A moeda. 3. ed. Rio de Janeiro: Zahar, 1969, p. 2.

${ }^{18}$ LOPES, João do Carmo; ROSSETTI, José Paschoal. Economia Monetária. 7. ed. São Paulo: Atlas, 1998, p. 19.
} 


\subsubsection{Intermediária de Troca}

Por meio da função de intermediária de troca, a moeda é inserida na economia monetária, substituindo a anterior e primitiva prática do escambo. O aumento da complexidade das trocas, que de diretas passaram a ser indiretas - com o surgimento do instrumento monetário - gerou um aumento da eficiência econômica e da diversidade de bens e serviços comercializados pelos indivíduos.

Com efeito, a função de meio geral de troca exercida pela moeda se relaciona ao conceito de troca indireta. Segundo $\mathrm{CORTEZ}^{19}$, na economia, as transações de troca ocorrem de duas formas distintas: (i) por meio do escambo, ou troca direta; e (ii) por meio de troca indireta. Assim, no escambo as duas partes envolvidas na relação recebem em contrapartida à sua prestação, mercadorias que serão utilizadas, em geral, para o seu consumo final.

De outro lado, na troca indireta, os agentes comercializadores não recebem em troca do produto do seu trabalho uma mercadoria a ser consumida, e sim, algo que lhes assegura condições de adquirir posteriormente os bens que necessitam para o seu consumo, ou seja, a moeda.

A função de intermediária de troca fez com que a moeda fosse considerada um instrumento facilitador da produção e da distribuição de bens e serviços necessários às exigências da sociedade. Ademais, com a conseqüente especialização das funções econômicas e de divisão do trabalho, houve uma elevação da produção por unidade de tempo e de fator, e um conseqüente aumento do bem-estar e da liberdade de escolha da sociedade e dos agentes econômicos.

Sem esgotar a esfera de possibilidades decorrentes da função de intermediária de troca da moeda, devemos ainda mencionar a promoção de condições necessárias à maior competitividade e racionalidade do sistema econômico em sua integralidade.

Resumidamente, são três os principais benefícios trazidos por esta função: (i) a especialização e divisão do trabalho, que apenas alcançam graus elevados se estiverem condicionados a uma economia monetária; (ii) a redução do custo e do tempo empregado nas transações, que também possibilita maior dinâmica das atividades humanas e mais atividades em menor demanda de tempo, e por fim (iii) a eliminação dos entraves inerentes ao processo de negociação e coincidência de vontades.

\footnotetext{
${ }^{19}$ CORTEZ, Tiago Machado (2004). Op. cit., p. 36.
} 
Relevante mencionar ainda, que para a efetiva concretização da função da moeda como meio de troca no mercado, necessário se faz que todas as demais funções sejam exercidas de forma coordenada e interligada, pois uma função influencia e determina o exercício da outra.

\subsubsection{Medida de Valor}

A moeda concentra em si uma unidade de medida, padronizada, e utilizada como referência para a conversão dos valores de todos os bens e serviços, comercializáveis ou não, em uma economia.

Ao incorporar a prerrogativa de medida de valor, foi a responsável pela substituição das trocas diretas, - vigentes nas sociedades primitivas -, pelas trocas indiretas, pois, enquanto nas trocas diretas os valores dos bens e serviços eram expressos em relação aos valores de outros bens e serviços, nas trocas indiretas, o valor da mercadoria ou do serviço passou a ser mensurado com base na unidade de valor instrumentalizada pela moeda. Assim, a moeda passou a concentrar em si a função de unidade de conta, ou seja, de medida padrão de valor.

Quando exerce a prerrogativa de unidade de valor, ou de unidade de conta, a moeda possibilita:

(i) a contabilização da atividade econômica e a administração racional das unidades de produção;

(ii) o aumento e a racionalização das informações de natureza econômica, por meio do sistema de preços;

(iii) a racionalização da atuação de produtores e consumidores, de forma a aumentar a eficiência do sistema econômico; e,

(iv) a criação de sistemas de contabilidade social, voltados ao cálculo dos valores agregados da produção e do consumo, dos investimentos, da poupança, e dos demais fluxos macroeconômicos relevantes à administração e ao planejamento da economia monetária.

Com efeito, a unidade monetária detém em si uma medida com base na qual o valor de qualquer outra mercadoria pode ser calculado. Portanto, o preço de uma 
mercadoria à venda no mercado, ou seja, o valor de troca da mercadoria calculado em unidades monetárias, corresponde à quantidade de moedas pela qual a mercadoria pode ser substituída nas condições normais de mercado.

Conforme pontua $\mathrm{CORTEZ}^{20}$, a relevância da função de medida de valor inerente à moeda para o funcionamento da economia de mercado não se restringe à possibilidade de atribuição de valor financeiro às mercadorias, pois, o fato de todas as mercadorias serem precificadas com base na moeda é o que permite aos agentes econômicos tomarem decisões econômicas racionais. Segundo o autor, o fato da economia de mercado se caracterizar por uma gestão racional formal da atividade econômica, faz com que os agentes orientem a sua atuação econômica com base em um cálculo de custos e benefícios voltado a maximizar suas utilidades.

A função de unidade de valor, ou de unidade de conta, exercida pela moeda, e também desempenhada pela URV ou pela $\mathrm{UFIR}^{21}$, está ligada à existência de uma unidade ideal, responsável pelo estabelecimento de relações de valor. Na prática corresponde à função da unidade monetária, que pode ser, por exemplo, o dólar, a libra esterlina, o marco alemão, ou o real, todas elas bases de sistemas monetários distintos.

Consoante o entendimento de ASCARELLI ${ }^{22}$, KEYNES $^{23}$ e $\operatorname{NUSSBAUM}^{24}$, a moeda é composta por dois elementos: os ativos que são o instrumento de pagamento e configuram a unidade monetária; e a unidade monetária propriamente dita. O que diferencia um e outro, portanto, é o fato de que a unidade monetária é um dos elementos da moeda, e se encontra intrinsecamente ligada aos ativos que a compõem.

Assim, as notas de papel que representam determinado valor em moeda corporificam a unidade monetária; e as demais unidades de conta, como o UFIR ou a URV, simbolizam uma medida de valor, que deverá ser convertida em uma unidade monetária, como por exemplo, o real, para efeito de pagamento de um débito.

A unidade monetária, diferentemente das demais unidades de conta, corresponde a um padrão geral de valor de troca, que, por sua vez, não é um conceito absoluto, e sim relativo. Ou seja, não havemos de encontrar nenhum bem ou serviço detentor de um valor

\footnotetext{
${ }^{20}$ CORTEZ, Tiago Machado (2004). Op. cit., p. 45.

${ }^{21}$ A URV e a UFIR serão mais detalhadamente estudadas no item 3.11.2.5 do presente trabalho, onde se trata do Plano Real.

${ }^{22}$ ASCARELLI, Tullio. Obbligazioni pecuniarie. Roma e Bolonha: Nicola Zanichelli, 1959, p. 13-15.

${ }^{23}$ KEYNES, John Maynard. A treatise on money. Vol. I. Londres: MacMillan and Co., 1950, p. 2-5.

${ }^{24}$ NUSSBAUM, Arthur. Money in the law national and international. A comparative study in the Borderline of law and economics. Brooklyn: The Foundation Press, 1950, p. 12-20.
} 
intrínseco. Portanto, o valor, por ser um conceito relativo, apenas pode ser mensurado com base na comparação entre mais de um bem, serviço ou mercadoria. Assim, um bem imóvel apenas terá o seu valor fixado em unidade monetária após ser comparado com outros bens imóveis similares, ou possuidores de melhoramentos distintos. Não é possível atribuir um valor a um bem ou serviço considerado de forma isolada.

Com base nos ensinamentos de $\mathrm{NUSDEO}^{25}$, doutrinador contemporâneo do direito econômico internacional, o valor de uma mercadoria ou de um serviço obtido com base na comparação com outras mercadorias e serviços, decorre da utilidade marginal do bem em questão, ou seja, de sua utilidade somada à escassez do bem.

Nesse sentido, a utilidade do bem depende de uma avaliação por um indivíduo ou grupo de indivíduos, e oscilará de acordo com o entendimento e as necessidades de cada um dos grupos. Configura, assim, um conceito relativo, ou subjetivo. E, aliado à idéia de utilidade, para que um bem tenha valor econômico, é essencial que agregue a esse conceito a qualidade de ser escasso no mercado, ou seja, de ser encontrado em quantidade insuficiente para satisfazer a toda a demanda da sociedade.

Para que uma relação de troca entre a moeda e um bem se efetive, necessário se faz o estabelecimento de uma relação de equivalência quantitativa entre os dois fatores, a mercadoria e a moeda. Assim, a moeda exerce o papel de denominador do sistema de preços, facilitando o funcionamento da economia de mercado.

Por sua vez, o sistema de preços exerce a função de mecanismo informacional, na medida em que informa à economia de mercado o valor ou a importância monetária de determinado bem, transformando bens qualitativamente distintos, em bens quantitativamente comparáveis.

De acordo com o valor atribuído a um bem, e com base nas condições de pagamento possibilitadas ao adquirente interessado, o processo de negociação e aquisição da mercadoria ou do serviço desenvolve-se, consolidando-se ou não. Nesse sentido, o preço das mercadorias corresponde à quantidade de moeda por meio da qual este bem pode ser substituído, possibilitando às pessoas adquirirem os bens que desejam a partir do pagamento com a moeda.

\footnotetext{
${ }^{25}$ NUSDEO, Fábio. Curso de economia. Introdução ao direito econômico. 2. ed. São Paulo: Revista dos Tribunais, 2000, p. 40-52.
} 
Segundo CORTEZ ${ }^{26}$, a moeda corresponde a uma instituição que viabiliza a relação entre os agentes nos mercados, na medida em que: (i) assegura a transmissão de informações necessárias para a sua interação, superando o problema da distinção qualitativa entre as mercadorias; e (ii) atua como instrumento que viabiliza as relações de troca.

Para o autor anteriormente $\operatorname{citado}^{27}$, a moeda exerce a função de um código comum entre os agentes econômicos nas suas relações comerciais, pois, de um lado, ao ser utilizada como uma medida para a definição dos preços no mercado, passa a transmitir informações relevantes à interação dos agentes na economia; e de outro lado, ao atuar como instrumento intermediário das trocas que corporifica todos os interesses dos agentes, ela confere segurança, agilidade e dinamismo ao mercado.

Ao explorar os requisitos inerentes à moeda, como instrumento modulador das trocas desenvolvidas no mercado, CORTEZ $^{28}$ nos chama a atenção para os seguintes aspectos a serem considerados:

Para que a moeda exerça esse papel institucional na economia de mercado ela deve, contudo, cumprir dois requisitos que the são essenciais: (i) ser objeto de desejo de todos os agentes; e (ii) ser um mecanismo de limitação das incertezas.

(...)

O que faz da moeda um objeto de desejo não é, pois, o proveito direto que alguém dela possa tirar, mas sim o benefício indireto que ela pode lhe trazer ao servir como instrumento para adquirir outros bens no mercado. Isto é, todos aceitam a moeda na medida em que têm certeza de que poderão exercer, futuramente, o poder de compra que nela está contido.

(...)

Por outro lado, a moeda só poderá atuar para limitar as incertezas dos agentes, caso ela continue a ser o objeto de desejo de todos, ou seja, na medida em que a moeda continue a ser amplamente aceita pela sociedade.

Observamos, assim, que a demanda excessiva sobre um bem, por parte da sociedade, faz com que ele alcance uma condição de valorização econômica no mercado superior àquela em que deteria caso existisse em quantidade suficiente para atender a toda a procura sobre ele. Portanto, o valor de um bem é mensurado com base na sua utilidade,

\footnotetext{
${ }^{26}$ CORTEZ, Tiago Machado (2004). Op. cit., p. 33.

${ }^{27}$ CORTEZ, Tiago Machado (2004). Op. cit., p. 33-34.

${ }^{28}$ CORTEZ, Tiago Machado (2004). Op. cit., p. 34.
} 
na sua escassez, e demanda por parte da sociedade, o que não raro, oscila de um momento para outro.

\subsubsection{Reserva de Valor}

A função de reserva de valor corresponde à faculdade da moeda de armazenar valor, ou riqueza, desde o momento em que é recebida até o momento em que é gasta ou empregada pelo seu titular. Há, no entanto, outros instrumentos financeiros, denominados “ativos", capazes de exercer esta função, não sendo considerada atribuição exclusiva da moeda. A única diferença reside, provavelmente, no fato de que, enquanto para os ativos financeiros a liquidez é sempre muito variável, a moeda detém liquidez certa e garantida.

A certeza da liquidez monetária decorre da facilidade com que é trocada, de forma direta, por outro bem, sem qualquer custo ao seu titular. Trata-se de característica ligada à noção de "vendabilidade", que confere ao ativo a facilidade e rapidez na sua venda por um valor mais próximo do seu valor de compra.

A liquidez, segundo DE CHIARA, relaciona-se à capacidade de circulação da moeda na economia como meio geral de troca, e é construída a partir da atuação conjunta da moeda nas suas funções de meio geral de troca e de reserva de valor. Para o autor:

(...) a situação de liquidez é uma situação jurídica de que se investe o sujeito em razão da titularidade da moeda. Essa situação jurídica lhe confere a prerrogativa de atuar nos mercados, segundo os níveis do poder de compra que decorrem das disponibilidades monetárias e conforme as permissões do ordenamento jurídico, como também lhe impõe ônus, ao manter a disponibilidade em moeda, notadamente o de correr o risco da desvalorização do padrão monetário ${ }^{29}$.

Ao deter a moeda, considerada o ativo de maior liquidez na economia, o seu titular passa a interagir com todo o mercado, influenciando comportamentos, impondo condições nas negociações, e alterando os preços dos produtos.

No entanto, em que pese a posição de dominação assumida no mercado pelo titular da moeda, DE CHIARA ${ }^{30}$ chama a atenção para o fato de que ao ser investido da situação de liquidez, o indivíduo se expõe para a sociedade, demonstrando uma fraqueza que não possuía anteriormente, na medida em deixa de depender apenas de si e passa a

${ }^{29}$ DE CHIARA, José Tadeu. Moeda e ordem jurídica. Tese de doutorado apresentada à Faculdade de Direito da Universidade de São Paulo, São Paulo, 1986, p. 60-72.

${ }^{30}$ DE CHIARA, José Tadeu. Op. cit., p. 70-81. 
depender de outras variáveis sobre as quais não tem controle, como por exemplo, o comportamento dos demais agentes do mercado, e a variação geral do índice geral de preços. Por certo, a situação de liquidez assumida pelo titular da moeda, configura situação relativa, diante da quantidade de moeda restante disponível na economia.

Concretamente, a situação de liquidez expõe a interdependência entre as funções de meio geral de troca e de reserva de valor desempenhadas pela moeda, e apesar de ser comumente considerada um instrumento de troca, para que essa função possa ser desempenhada em toda sua plenitude, necessário se faz que a moeda sirva como reserva de valor, pois na medida em que assume essa condição, passa a ser utilizada como um instrumento intertemporal do poder de compra ${ }^{31}$.

Em razão disso, a titularidade da moeda confere ao agente a opção de antecipar ou postergar sua decisão de compra, de forma a obter o maior benefício possível desta disponibilidade da moeda, seja planejando os próprios gastos, seja aguardando a queda do preço do produto a ser adquirido ${ }^{32}$.

Assim, a função de reserva de valor da moeda é definida como a capacidade de transmitir o poder de compra no tempo e no espaço, e a manutenção desse poder equivale à constância do seu valor frente ao valor de todos os demais produtos da sociedade considerados em conjunto ${ }^{33}$.

Ainda que previamente constatada, a função de reserva de valor inerente à moeda foi, pela primeira vez, estudada com maior profundidade por KEYNES, em sua Teoria Geral, publicada em $1936^{34}$.

De acordo com LOPES e ROSSETTI, a preferência pela utilização da moeda como reserva de valor, em detrimento dos demais ativos financeiros existentes, deve-se, em primeiro lugar, à ampla e imediata aceitação da moeda, e à sua possível conversão em outros ativos financeiros ou reais em vasto espaço geográfico. Em segundo lugar, deve-se à ausência de previsibilidade do valor futuro dos demais ativos financeiros e não financeiros, o que gera uma constante incerteza ao mercado financeiro ${ }^{35}$.

Por conseguinte, a reserva de valor tem como razões principais a pronta e imediata aceitação da moeda, condicionada à região à qual está em vigor, e a imprevisibilidade dos

\footnotetext{
${ }^{31}$ CORTEZ, Tiago Machado (2004). Op. cit., p. 44.

${ }^{32}$ CORTEZ, Tiago Machado (2004). Op. cit., p. 39.

${ }_{33}$ CORTEZ, Tiago Machado (2004). Op. cit., p. 39.

34 Ver: KEYNES, John Maynard. General theory of employment, interest and money. Londres: MacMillan, 1977. Original, 1936.

${ }^{35}$ LOPES, João do Carmo; ROSSETTI, José Paschoal. Op. cit., p. 22.
} 
demais ativos, visto que muitos perdem sua reversibilidade, como os bens de uso durável que não podem voltar ao preço original com que foram adquiridos.

Em que pese o fato da função de reserva de valor da moeda representar condição fundamental para a ocorrência das trocas indiretas na economia, a perda do poder de compra desta acarreta um custo àqueles que a armazenam entre os momentos da venda de um bem e da compra de um outro produto. Segundo Cortez ${ }^{36}$ :

(...) a manutenção do poder de compra da moeda não pode ser verificada diante da estabilidade do preço de um único produto, mas sim de todos os bens e serviços disponíveis no mercado. Ademais, há a alteração nos preços relativos desses produtos e serviços, o que faz com que a moeda, como qualquer outro ativo, nunca possa servir como um instrumento de reserva de valor perfeito. No entanto (...) a desvalorização do valor da própria moeda frente ao valor dos demais produtos, quanto causada por fatores de ordem exclusivamente monetária, impõe um custo para que os agentes econômicos realizem trocas indiretas.

Com efeito, observamos que a perda do poder de compra da moeda é diretamente proporcional ao ônus sofrido pelos agentes econômicos que realizam as trocas utilizando-a como instrumento de reserva de valor, e sua desvalorização em um curto espaço de tempo fará com que as trocas indiretas se tornem ineficientes aos agentes econômicos.

\subsubsection{Padrão de Pagamentos Diferidos}

Em razão de seu caráter de reserva de valor, e de sua capacidade de liquidar débitos a partir do pagamento ao credor, a moeda também é considerada padrão de pagamentos diferidos, por possibilitar a negociação dos pagamentos ao longo do tempo, facilitando-os assim ao devedor e ao credor. Tal prerrogativa decorre da concessão de créditos ou de outras formas de adiantamentos pecuniários ou não-pecuniários, e têm caráter de promessas de liquidação financeira.

Os salários configuram uma forma de pagamento diferido, ou ainda, uma espécie de adiantamento, capaz de, além de remunerar o trabalho prestado, viabilizar os fluxos de produção e a circulação da renda, que por vezes decorrem da concessão de créditos ou da antecipação de pagamentos.

\footnotetext{
${ }^{36}$ CORTEZ, Tiago Machado (2004). Op. cit., p. 40-41.
} 
Dessa forma, ainda que a produção de um determinado montante de bens por uma empresa não esteja concluída no final do mês, a empresa tem o compromisso de remunerar seus funcionários e de arcar com todos os ônus relativos ao processo produtivo, como impostos, compra antecipada de matéria-prima, manutenção das despesas do estabelecimento, entre outros encargos.

Sem dúvida uma função de alta relevância para a economia contemporânea, sobretudo por facilitar as atividades de produção, consumo e investimento.

\subsubsection{Instrumento Liberatório}

A função liberatória confere à moeda a capacidade de livrar o seu titular de uma dívida, de um débito, ou de qualquer outra situação de inadimplência, pois a moeda detém o poder de liquidar débitos, por ser uma unidade de valor instrumentalizada.

$\mathrm{O}$ ordenamento jurídico, por meio de suas normas, e o sistema financeiro nacional, por meio de órgãos especializados e corporificadores da figura do Estado, asseguram a utilização da moeda como forma de pagamento, por representar unidade de valor monetário.

No entanto, a aceitação geral da moeda não compete exclusivamente ao Estado, pois esta depende muito mais da própria disposição social onde a moeda circula. Exemplos citados por LOPES e ROSSETTI ${ }^{37}$ - como a hiperinflação dos assignats na Revolução Francesa e a hiperinflação alemã entre as duas Guerras Mundiais - mostram que a imposição estatal muitas vezes não consegue quebrar a barreira da desconfiança sobre o valor da moeda, fator determinante para a impossibilidade de efetivar-se a função liberatória da moeda.

\subsubsection{Instrumento de Poder Econômico e Político}

A moeda é considerada instrumento de poder econômico e político ao assumir a função de título de crédito, o que confere ao seu titular a prerrogativa de decidir sobre a aquisição de bens e serviços disponíveis no mercado. Há doutrinadores, como KEYNES, que observam a possibilidade desse poder ser utilizado pelo homem de maneira desenfreada, ou como forma de engrandecimento pessoal ${ }^{38}$.

\footnotetext{
${ }^{37}$ LOPES, João do Carmo; ROSSETTI, José Paschoal. Op. cit., p. 23.

${ }^{38}$ KEYNES, John Maynard.(1977). Op. cit., p. 370-380.
} 
Nesse sentido, Bruno THÉRET afirma o seguinte ${ }^{39}$ :

Através da representação da dívida de vida ${ }^{40}$, moeda e soberania mantêm, portanto, uma relação constitutiva estreita até mesmo em suas ambivalências respectivas. Pois é pela circulação da moeda e um ciclo interrompido de pagamentos que a sociedade se reproduz e aparece aos olhos de seus membros como eterna, imortal, e, portanto, autoridade soberana.

É notório que tal poder, atribuído à moeda, confere ao seu titular a capacidade de influenciar as decisões e estratégias de seu próprio negócio, ou ainda, de auxiliar no desenvolvimento e crescimento econômico de seu país.

\section{4 - Características da Moeda}

Ao longo da evolução histórica dos povos e da construção de um sistema econômico com certo grau de organização e efetividade nas transações monetárias e financeiras, a moeda adquiriu fundamental relevância como instrumento capaz de concentrar em si um padrão de valor e de poder econômico, voltado a direcionar as decisões sobre os investimentos nas esferas pública e privada. Assim, evoluiu e se adequou às necessidades da sociedade moderna, agregando novos formatos e funções, e se tornando o instrumento fundamental do sistema monetário.

Dentre as características mais marcantes da moeda pontuadas por $\mathrm{SMITH}^{41}$, encontram-se: (i) divisibilidade; (ii) homogeneidade; (iii) transferibilidade; (iv) indestrutibilidade e inalterabilidade; e por fim, (v) facilidade de transporte e de manuseio.

\subsubsection{Divisibilidade}

Devido ao elevado número de transações econômicas efetuadas diariamente, seja em âmbito nacional, seja no internacional, e à diversidade de valores envolvidos nas negociações, é de suma relevância que a moeda seja produzida e circule detendo diversos

\footnotetext{
39 THÉRET, Bruno. Op. cit., p. 6.

40 “A vida é, portanto, o objeto de uma dádiva que está na origem de relações de endividamento específicas, que podemos qualificar de dívida de vida: cada ser humano se vê de fato reconhecido socialmente como dotado de um capital de vida ("reserva de vida") mais ou menos importante e mais ou menos valorizado segundo o status social, podendo ser apropriado de diversas formas e ser o objeto de diversas transações que levem à criação e circulação de dívidas". In: THÉRET, Bruno. Op. cit., p. 6.

${ }^{41}$ SMITH, Adam. Riqueza das nações. Rio de Janeiro: Ediouro, 1986, p. 65.
} 
valores, ou seja, que possua múltiplos e submúltiplos em vasta quantidade e variedade, a fim de garantir a concretização de transações envolvendo elevados ou reduzidos valores pecuniários.

\subsubsection{Homogeneidade}

Para que a moeda possa cumprir as funções de instrumento de troca e de instrumento de valor, é essencial que duas ou mais unidades monetárias distintas, de idêntico valor, sejam rigorosamente iguais.

\subsubsection{Transferibilidade}

Com o intuito de facilitar a sua transferência de um titular a outro, é necessário que a moeda não detenha qualquer registro ou sinal, quando materializada em uma mercadoria, de forma a vincular-se ao titular anterior. A moeda configura apenas um instrumento de valor, um meio para se obter determinado bem ou serviço, motivo pelo qual, não deve estar vinculada ao seu possuidor ou ao Estado emissor.

\subsubsection{Indestrutibilidade e Inalterabilidade}

A indestrutibilidade e a capacidade de não sofrer alterações de conteúdo e de materialidade configuram requisitos necessários à aceitação e à confiabilidade da moeda pela sociedade. A durabilidade garante a intermediação das trocas e a certeza de que não se trata de instrumento perecível e passível de ser destruído ou falsificado por qualquer indivíduo que a detenha.

\subsubsection{Facilidade de Transporte e de Manuseio}

A moeda, desde seu primeiro formato até hoje, vem se adaptando às exigências de transporte pela sociedade. A cunhagem da moeda em metal facilitou sobremaneira o seu transporte e manuseio nas transações econômicas, e a utilização de metais preciosos, como o ouro e a prata, garantiram à moeda, durante o seu período de vigência, um pequeno volume e um elevado valor. 


\section{5 - Aspectos Sociológicos}

A moeda é, ao mesmo tempo, uma linguagem específica (o sistema de contas), um objeto (os instrumentos de pagamento), e uma instituição (as regras de moedagem). Ela não é somente um objeto, uma mercadoria-meio de troca mercantil. Tampouco, é somente uma simples linguagem especial de comunicação. Por fim, ela extrapola o mero entendimento de ser uma instituição, um sistema de regras. A moeda é um fato social total que tem simultaneamente estas três dimensões, sendo um fenômeno ao mesmo tempo econômico, político e simbólico ${ }^{42}$.

É de considerar-se, ainda, a moeda como um elemento de mediação social. Nesse sentido, a moeda constitui uma das três grandes formas de mediação social que recompõem a sociedade e que em conseqüência fazem com que os homens sigam vinculados entre si.

As relações de troca somente se dão entre os homens, que se distinguem dos animais por serem os únicos que podem estabelecer transações de troca. Além disso, o homem e a sociedade mudaram quando transcenderam a troca de mercadorias, adotando a troca por intermédio da moeda, já que estas transações estreitaram a convivência dos seres em um determinado espaço econômico ao estabelecer uma equivalência (padrão geral), ao mesmo tempo em que se desenvolvia a unidade de conta, o crédito, que não somente agiliza as transações de mercadorias entre os comerciantes, mas também os circuitos da esfera produtiva e financeira.

A moeda é mais que uma concepção abstrata pertencente ao homem e à sociedade em uma relação dialética uma vez existente um processo de maturação do desenvolvimento das civilizações. A moeda é poder nas mãos da autoridade. Assim, o poder sobre os meios de troca da sociedade é determinado pela autoridade e exercido por meio da da moeda. Em acréscimo, o exercício do poder monetário determina o espaço econômico e o fortalecimento das trocas. As sociedades maduras que exercem o poder monetário promovem o bem estar econômico do povo e o povo, por sua vez, logra o bem estar pelo crédito outorgado pelo Estado ${ }^{43}$.

Em uma economia de mercado, como a sob a qual vivemos, a troca é verificada com base em uma orientação racional das decisões dos agentes, o que difere da troca

\footnotetext{
42 THERET, Bruno. Op. cit, p. 20.

${ }^{43}$ GIRON, Alicia. Moneda, poder y sociedad. Disponível em: <http://es.pekea-fr.org/sr-mx/Giron.pdf>. Acesso em: 5 dez. 2008, p. 9.
} 
encontrada em outros sistemas econômicos, concretizada em razão dos costumes ou da tradição. Conforme WEBER, a racionalidade que conduz a ação econômica de troca pode ser subdividida em: (i) racionalidade formal, em que a tomada de uma decisão se baseia em critérios quantitativos e técnicos; e, (ii) racionalidade material, em que a ação econômica se orienta por critérios de valor, conquanto formalmente racional ${ }^{44}$.

A ação econômica racional formal consiste na consideração pelo agente, de um ponto de vista técnico, da relação entre meios e fins envolvidos na relação, com o intuito de ponderar qual a melhor decisão a ser tomada. Por outro lado, na racionalidade material a ação econômica não utiliza como critério de avaliação a relação entre meios e fins, e sim os valores de ordem política, moral, ética, psicológica, religiosa e outros, envolvidos nas conseqüências decorrentes da ação econômica ${ }^{45}$.

Nesse sentido, observamos que em uma economia de mercado há a predominância da racionalidade formal nas relações econômicas individuais dos atores. Na medida em que o mercado atua como instância integradora do processo econômico, um conseqüente aumento da relevância da racionalidade formal é constatado na tomada de decisões econômicas, e o principal instrumento capaz de viabilizar nesse processo econômico instaurado em uma economia de mercado é a moeda.

Conforme pontua CORTEZ, a moeda é instrumento que torna viáveis as múltiplas relações de troca que o mercado potencializa ${ }^{46}$. De acordo com o pesquisador, a moeda representa um código, verdadeiro instrumento de comunicação entre os agentes econômicos em uma economia de mercado, sendo utilizada como denominador comum do sistema de preços, e como objeto geral de corporificação da riqueza individual, que acentua do sentimento de antagonismo subjacente ao mercado ${ }^{47}$.

Nas relações de mercado, baseadas na troca, os agentes econômicos individuais se relacionam uns com os outros em igualdade. Os produtos conquistados a partir do trabalho de um indivíduo são trocados por bens que o agente necessita e o sucesso das trocas comerciais consiste na obtenção pelos agentes, individualmente considerados, dos maiores ganhos possíveis em suas negociações ${ }^{48}$.

\footnotetext{
${ }^{44}$ WEBER, Max. Economía y sociedad. Esbozo de sociologia comprensiva. México: Fondo de Cultura Econômica, 1994, p. 64.

${ }^{45}$ Idem.

${ }^{46}$ CORTEZ, Tiago Machado (2004). Op. cit., p. 23.

${ }^{47}$ CORTEZ, Tiago Machado (2004). Op. cit., p. 24.

${ }^{48}$ FERRAZ JÚNIOR, Tercio Sampaio; MAGLIANO FILHO, Raymundo. A bolsa de valores como sistema de poder. Revista de Direito Econômico, nº 14, maio/agos. 1980, p. 7-20.
} 
Segundo aponta $\mathrm{WEBER}^{49}$, em uma sociedade de mercado, em que a troca é elemento integrador, dois institutos são observados: a liberdade de contratar e a propriedade privada, postulados garantidos constitucionalmente no ordenamento jurídico brasileiro, notadamente tutelador de um sistema econômico de mercado.

Deste modo, a liberdade de contratar permite ao agente particular negociar as melhores condições para si, com base em seus próprios interesses e possibilidades de troca. A propriedade privada, por sua vez, assegura a titularidade do bem ao indivíduo, conferindo-lhe os limites de seus direitos e deveres na negociação da mercadoria.

\section{6 - Evolução Histórica dos Primeiros Subsistemas Monetários Existentes. O Surgimento da Moeda}

Ao longo da história da civilização, a moeda passou de instrumento de troca, como moeda-mercadoria, para as condições de reserva de valor e de meio de pagamento ${ }^{50}$. A economia de mercado, fruto da sociedade contemporânea, não existia nas economias antigas e primitivas.

Assim, imagine-se uma comunidade na qual inexista qualquer tipo de moeda. Agora, suponhamos que um indivíduo "A”, proprietário da mercadoria "a”, queira trocá-la pela mercadoria "b", que é produzida pelo indivíduo "B". Se, por hipótese, este último estiver de acordo em trocar uma ou algumas unidades de sua mercadoria "b" por uma ou algumas unidades do produto "a", a transação ocorrerá. Caso contrário, o indivíduo "A" terá que procurar um outro, que também seja produtor do artigo "b" e, o que é mais importante, esteja disposto a trocá-lo pelo produto de " $\mathrm{A}$ " 51 .

\footnotetext{
${ }^{49}$ WEBER, Max (1994). Op. cit., p. 67.

${ }^{50}$ No princípio, a troca de mercadorias por mercadorias, o escambo, foi a verdadeira natureza da atividade comercial. Com o aumento do volume de transações e a inclusão de bens imóveis no comércio, o escambo tornou-se excessivamente complicado. Institui-se então um padrão de valor, eixo organizador das trocas. Nesse sentido, MALYNES, Gerrard. A treatise of the canker of England's common wealth, London, edição fac-símile, 1601, p. 6-7; MISSELDEN, Edward. Free trade or the meanes to make trade flourish, London, edição fac-símile, 1622, p. 20-21.

51 “Até os povos nômades se tornarem sedentários, com o surgimento da agricultura, da criação de animais domésticos e de aldeias, no chamado período neolítico, o que no Oriente Médio e na China ocorreu entre 9000 e 7500 antes de Cristo (a.C.), eventuais 'transações comerciais' ocorriam através da troca direta ou escambo de bens. Ou seja, um produto pelo outro, sem que um bem específico servisse de padrão de referência ou meio de pagamento exclusivo." LAGO, Luiz Aranha Corrêa do. A moeda metálica em perspectiva histórica: notas em torno de uma exposição. Departamento de Economia - PUC, 2004, p. 6 Disponível em: <http://www.econ.puc-rio.br/pdf/td481.pdf>. Acesso em: 4 dez. 2008.
} 
Considere-se, ainda, a existência de uma mercadoria aleatória (conchas, por exemplo) $)^{52}$, e que seja livremente aceita por todos os indivíduos da comunidade. Então, o esquema de trocas assume uma nova feição: "A" trocará seu produtos por conchas e com elas adquirirá de "B" a mercadoria de que necessita.

Dessa forma, as mercadorias mais aceitas foram se tornando cada vez mais procuradas, passando a ser utilizadas como intermediárias de troca. Entretanto, pouco a pouco, a preferência dos indivíduos foi se concentrando naquela que fosse mais facilmente permutável, surgindo, com isso, um padrão de trocas e de comparação dos valores dos demais produtos. A escolha dependia das condições sociais e econômicas de cada grupamento humano. Esse produto-padrão passou a constituir, então, a moeda da comunidade $^{53}$.

Por aí, verifica-se que as causas que deram origem ao surgimento da moeda foram: a necessidade de facilitação das trocas e a necessidade de se obter uma base para a comparação de valores.

Contudo, outro problema se apresentou: que mercadoria poderia ser aceita como moeda? No início, eram consideradas aquelas que apresentavam maior valor para os indivíduos. Conforme a época e o grupo, tivemos conchas, sal, peles, cereais, gado etc. Evidentemente, essas "moedas" apresentavam diversos inconvenientes, especialmente com relação ao transporte das mesmas. Imagine-se, por exemplo, o caso do gado.

Depois de muito refletir, chegou-se à conclusão de que a melhor moeda era a metálica. Era mais fácil de transportar. Não se estragava facilmente. Podia ser dividida em "fatias" para os pequenos pagamentos etc. Assim, foram adquirindo grande uso, para fins monetários, os metais preciosos, como o ouro e a prata ${ }^{54}$. O cobre e o ferro também foram utilizados com a mesma finalidade, porém, como passaram a ser descobertos em grande quantidade, acabaram por perder uma característica relevante - a sua raridade relativa -, condição indispensável para a sua utilização como moeda.

Acontece que o ser humano como animal comodista que é e objetivando proteger-se de possíveis roubos, depositava essas moedas, bem como barras de ouro e de

\footnotetext{
${ }^{52}$ A troca em que a unidade de valor de uma dada mercadoria era aceite e reconhecida por toda a comunidade (moeda-mercadoria) - por exemplo as conchas na África, o chá no Tibete, cabeças de gado dos pastores, etc.

${ }^{53}$ OLIVEIRA, Marcos. Moeda, juros e instituições financeiras: regime jurídico. Rio de Janeiro: Forense, 2006, p. 113.

${ }^{54}$ As moedas de prata, de menor valor, constituíam o principal instrumento de trocas, ao passo que as moedas de ouro eram reservadas para transações de grande porte, em especial aquelas que envolviam o transporte de moeda por longas distâncias. Cada região adotava uma taxa de conversão entre ouro e prata, que variava razoavelmente de acordo com a oferta e demanda relativas de cada metal.
} 
prata, junto aos ourives (que eram os banqueiros da época), em troca de um recibo comprobatório desse depósito. Assim, ao efetuar um pagamento, em lugar de se dirigir ao ourives e retirar o depósito em metal, o que representava trabalho e implicava perda de tempo, além do risco de roubo, o depositante passou a se utilizar desses recibos para saldar seus compromissos. Eis aí o surgimento das primeiras notas bancárias ${ }^{55}$.

Nota-se, conseqüentemente, que a moeda foi submetida a um processo contínuo de desmaterialização: Passou de moeda-mercadoria para moeda metálica; depois para moeda-papel e, por fim, para moeda escritural, que constitui o ponto alto desse processo de desmaterialização.

Mas o que vem a ser, então, esse fascinante e cobiçado objeto chamado moeda?

Segundo os economistas clássicos, como Thomas Malthus, David Ricardo e John Stuart Mill, que escreveram entre 1770 a 1870, a moeda seria uma mercadoria dotada de valor de troca e de uso, de aceitação geral e de fácil conservação, utilizável como instrumento para facilitação das trocas ${ }^{56}$.

Interessante observar que os registros de moedas datam do século VII a.C., quando já eram cunhadas na Lídia, reino da Ásia Menor, e também no Peloponeso, no sul da Grécia $^{57}$. Na verdade, sua história coincide com a descoberta do uso dos metais e o domínio das técnicas de mineração e fundição. Assim, as moedas de cobre - metal mole e pouco adequado ao manuseio -, cederam lugar às duráveis moedas de bronze feitas a partir de uma liga de cobre com estanho ou zinco ${ }^{58}$.

Posteriormente, porém, a moeda passou a não ser mais metálica, mas sim simbólica: tornou-se apenas um pedaço de papel $^{59}$ (com exceção das pequenas moedas para troco).

\footnotetext{
55 "Em 1338, um carregamento de moedas requeria três semanas para fazer seu caminho de Rouen, no norte da França, a Avignon, no sul, uma distância de aproximadamente $700 \mathrm{~km}$, e o carregamento ainda corria o risco de ser perdido, roubado ou apropriado pelas próprias pessoas contratadas para transportá-lo." WEATHERFORD, J. McIver. The history of money. New York: Three Rivers Press, 1997, p. 75.

${ }^{56}$ BLAUG, Mark. Classical Economics. The New Palgrave: A Dictionary of Economics, vol. 1, 1987, p. 434435.

57 "Na Grécia, no século VIII a.C. faziam-se as contas tomando o boi como parâmetro: uma mulher valia de vinte a quarenta cabeças de gado; um homem, cem" KAMINSKI, N.; MAUCH Palmeira, E.. A política econômica e o sistema monetário. In: Observatorio de la Economía Latinoamericana, n ${ }^{\circ}$ 85, 2007. Disponível em: <http://www.eumed.net/cursecon/ecolat/br/>. Acesso em: 4 dez. 2008.

${ }^{58}$ GAROFALO FILHO, Emilio. Dicionário de comércio exterior e câmbio. São Paulo: Saraiva, 2004, p. 174.

59 "No início, eram certificados de depósito ou letras de câmbio emitidas por comerciantes, normalmente ourives, que rapidamente vieram a se tornar os banqueiros da Idade Média, que os entregavam como garantia dos metais recebidos em depósito. A letra de câmbio era um instrumento bastante criativo que permitia a uma pessoa - o doador - fornecer a outra - o tomador - certa quantidade de moedas emitidas por uma cidade,
} 
Dissertando acerca dos motivos para essa transição, assim escreve FRIEDMAN:

Padrões-mercadoria verdadeiros se desviaram enormemente deste simples padrão que não necessita de intervenção governamental. Historicamente, um padrão de commodities - como o padrão-ouro ou o padrão-prata - tem sido acompanhado pelo desenvolvimento de moeda fiduciária de um tipo ou de outro, aparentemente conversível na "mercadoria" monetária em termos fixos. Houve uma boa razão para esse desenvolvimento. A falha fundamental como um todo, é que isso exige o uso de recursos reais para adicionar ao estoque de moeda. Pessoas precisam trabalhar duro para cavar ouro do solo da África do Sul, a fim de reenterrá-lo no Fort Knox ou algum lugar similar. A necessidade de usar recursos reais para a operação de um padrão de commodities cria um forte incentivo para as pessoas encontrarem meios de atingir o mesmo resultado sem empregar esses recursos. Se as pessoas vão aceitar como dinheiro pedaços de papel em que conste impresso: "Eu prometo pagar unidades do padrão-mercadoria", estes pedaços de papel podem cumprir a mesma função que as peças físicas de ouro ou prata, e demandam muito menos em recursos para produzir. Este ponto (...) parece a mim a dificuldade fundamental de um padrão-mercadoria ${ }^{60}$ (Tradução livre)

Por esse motivo, a doutrina moderna ${ }^{61}$ prefere definir a moeda apenas pelas suas funções ${ }^{62}$, dizendo que: "Moeda é um bem instrumental que facilita as trocas e permite a medida ou a comparação de valores" "63 ou, ainda, que é "bem econômico qualquer que desempenha as funções básicas de intermediário de trocas, que serve como medida de valor e que tem aceitação geral" ${ }^{\text {64 }}$. Nesse sentido, é interessante atentar que a função

recebendo em troca o compromisso do tomador de entregar, em uma data futura, uma dada quantidade de moedas emitidas por outra cidade. Assim, as letras serviram simultaneamente como instrumentos de câmbio de moedas e de crédito." OLIVEIRA, Marcos. Moeda, juros e instituições financeiras: regime jurídico. Rio de Janeiro: Editora Forense. 2006, p. 118.

${ }_{60}$ Actual commodity standards have deviated very far from this simple pattern which requires no governmental intervention. Historically, a commodity standard - such as a gold standard or a silver standard - has been accompanied by the development of fiduciary money of one kind or another, ostensibly convertible into the monetary commodity on fixed terms. There was a very good reason for this development. The fundamental defect, as a whole, is that it requires the use of real resources to add to the stock of money. People must work hard to dig gold out of the ground in South Africa, in order to rebury it in the Fort Knox or some similar place. The necessity of using real resources for the operation of a commodity standard establishes a strong incentive for people to find ways to achieve the same result without employing these resources. If people will accept as money pieces of paper on which is printed "I promise to pay ------ units of the commodity standard", these pieces of paper can perform the same function as the physical pieces of gold or silver, and they require very much less in resources to produce. This point, (...), seems to me the fundamental difficulty with a commodity standard. FRIEDMAN, Milton. Op. cit., p. 40.

${ }^{61}$ Para maiores detalhes, consultar: GREMAUD, Amaury Patyrick; et al. Manual de economia. 4. edição. São Paulo: Saraiva, 2004; SCHEINER, Andrei. História da moeda. Textos, Artigos e Análises. Disponível em: <http:// www.bancocentral.gov.br.htm>. em: 3 dez. 2008.

62 "Na realidade, a noção de função só pode servir para definir a moeda se ela remete a formas operacionais de seu funcionamento próprio como relação social específica. É a única maneira de conceber as atribuições da moeda coerente com a idéia de que o conceito geral abstrato de moeda corresponde a uma invariante antropológica e é conseqüentemente o pressuposto de toda economia monetária.” THERET. Op. cit., p. 1-28.

${ }^{63}$ RATTI, Bruno. Comércio internacional e câmbio. São Paulo: Aduaneiras, 2006, p. 22.

${ }^{64}$ Ibid., p. 18. 
somente servirá para a definição do termo "moeda" caso remeta a formas operacionais de funcionamento próprio como relação social específica ${ }^{65}$.

${ }^{65}$ THERET. Op. cit., p. 1-28. 


\section{CAPÍTULO II}

\section{A MOEDA NO MUNDO}

\section{1 - Antigüidade}

Partindo do princípio de que a moeda assumiu um papel de extrema significância para a manutenção das relações econômicas e sociais modernas, não é tão simples imaginar que, nos primórdios da civilização humana, não havia qualquer sistema ou organização semelhante ao sistema monetário, e as poucas relações de interação humana se sustentavam nas trocas diretas de mercadorias, o denominado escambo ${ }^{66}$.

Não há de se falar em diversidade e sofisticação das necessidades dos povos primitivos. Estes apenas se preocupavam com a manutenção das condições básicas de sobrevivência, como a alimentação e o vestuário, apenas com o fim de assegurar a proteção contra as mudanças climáticas e as doenças existentes. Os grupos humanos primitivos, em sua essência, caracterizavam-se pelo nomadismo, e exerciam atividades de caça, pesca e coleta de alimentos disponibilizados pela natureza, o que lhes conferia uma condição rudimentar de sobrevivência.

Para bem assegurar a sua proteção contra as intempéries da natureza e garantir a alimentação e a manutenção das necessidades básicas dos demais membros da família, os grupos humanos tinham o hábito de armazenar alimentos para um momento futuro de possível escassez. Nas sociedades econômica e culturalmente mais desenvolvidas os indivíduos efetuavam pequenas trocas de alimentos e vestuários uns com os outros, o que se dava diretamente em espécie, através de operações denominadas escambo, destituídas de qualquer instrumento monetário.

A partir da chamada "revolução agrícola"67, as formas de relacionamento entre os povos atingiram um desenvolvimento maior, possibilitando aos grupos humanos uma mais

\footnotetext{
${ }^{66}$ De acordo com MISHKIN, escambo é uma espécie de economia onde não há moeda e na qual bens e serviços são trocados diretamente por outros bens e serviços. (MISHKIN, Frederic S. Moedas, bancos e mercados financeiros. 5. ed. Trad. STUART, Christine Pinto Ferreira. Rio de Janeiro: LTC, 2000, p. 32).

${ }^{67}$ É no período Neolítico, por volta de 10 mil anos a.C., que a terra passa por uma grande mudança no clima, ocasionando uma serie de modificações na vegetação e nos hábitos dos animais Conseqüentemente os seres
} 
completa interação social e econômica, em decorrência da fixação dos indivíduos dos indivíduos em locais próximos às regiões drenadas pelos rios Eufrates, Tigre e Nilo ${ }^{68}$, e o conseqüente desenvolvimento de atividades ligadas à agricultura, à pesca e à domesticação de animais.

Desta maneira, nas imediações do crescente fértil ${ }^{69}$, os grupos humanos foram substituindo pouco a pouco o caráter nômade de vida pelo "sedentarismo", e as comunidades estreitaram seus laços de relacionamento social. Os povos, a partir de uma vida em comunidade, passaram a buscar novas alternativas de produção, de integração, de relacionamento laboral, social e de divisão de poderes no interior da comunidade.

Observamos, assim, ao longo da Idade Antiga, um crescente aumento da complexidade das relações humanas e econômicas, bem como uma sensível evolução do número de bens e serviços necessários à satisfação das necessidades dos indivíduos e dos grupos humanos. A troca, que no início era praticada apenas pelos grupos mais desenvolvidos, passa a ser condição essencial à sobrevivência das comunidades como um todo.

Com o aumento da interação econômica, as trocas diretas são substituídas por trocas indiretas, ou seja, o escambo, em grande parte, é substituído por processos indiretos de pagamentos.

Conquanto as comunidades antigas não possuíssem um sistema monetário, ou mesmo um conjunto de regras próprias às relações monetárias, o processo de aceitação de determinados bens como pagamento de transações e negociações econômicas efetuadas, pode ser considerado o passo inicial para a constituição ou o nascimento da moeda, ainda que não instrumentalizada. Tais produtos negociados e aceitos como pagamento, figuravam como intermediários das trocas, e eram aceitos pelos grupos, como pagamento, sem restrições.

À medida que as relações de troca foram sendo substituídas por relações de compra e venda e determinados produtos alcançaram a condição de "produtos-padrão", ou

humanos tiveram de se ajustar a um novo ambiente. Essa adaptação caracterizou-se pelo cultivo de plantas e a domesticação de animais. Nos milênios que se seguiram houve um aumento significativo da população humana .A descoberta da agricultura(aprendizado do cultivo de plantas) pelo homem explica esse aumento.Esse fato foi denominado por muitos estudiosos de Revolução Agrícola. Para maiores informações, consultar TITIEV, Misha. Introdução à antropologia cultural. 8. ed., Fundação Calouste Gulbenkian, p. 134-137 e Reed, Charles in "The Origins of Agriculture".

${ }^{68}$ Região ocupada, atualmente, pelo Iraque, Síria, Turquia, Uganda, Sudão e Egito.

${ }^{69}$ Região do Oriente Médio que compreende, na atualidade, o Líbano, Cisjordânia e Israel, bem como partes da Jordânia, Iraque, Egito, Síria e sudeste da Turquia. 
intermediários de troca, por contarem com a aceitação geral das comunidades na intermediação das transações econômicas, as relações monetárias, ainda que primitivas, atingiram um grau inicial de sofisticação. A moeda utilizada nesse período é denominada moeda-mercadoria, pois assumia a forma de um determinado objeto passível de troca, que variava de comunidade para comunidade.

Observa-se, então, que, ao longo desse período, foram utilizados como moedasmercadorias: o sal, as pedras, o gado, o cigarro, as conchas, e outros. Contudo, a adoção do gado como meio de troca prevaleceu sobre os demais bens, configurando o motivo da utilização da palavra "pecúnia” para as relações monetárias, cuja origem remonta ao termo pecus, que no latim significa gado ${ }^{70}$.

\section{2 - Idade Média}

Durante a Idade Média, não há propriamente que se falar em uma evolução da utilização da moeda, que se subordinava às deliberações dos reis e príncipes. Estes lhe atribuíam e alteravam valor de acordo com os interesses fiscais ou de arrecadação do reino.

Mesmo sem muito padrão científico e matemático, já nesse período, Nicolau Oresme $^{71}$, doutrinador escolástico, defendia a estabilidade monetária como a única forma de oferecer segurança econômica ao Estado e à população, em contraposição à arbitrária

\footnotetext{
70 "pecus : a single head of cattle, especially a sheep/ a herd" LATIN DICTIONARY AND GRAMMAR AID. University of Notre Dame. Disponível em: <http://www.archives.nd.edu/cgi-bin/lookit.pl?latin=pecus>. Acesso em: 6 dez. 2008.

${ }^{71}$ Nicoulau Oresme (1323-1382), cujo nome aparece, frequentemente, nas seguintes formas: Nicole d' Oresme, Nicole Oresme, ou Nicolas de Oresme; foi matemático, economista, físico, astrônomo, filósofo, psicólogo, musicólogo, teólogo, bispo e tradutor, tendo atuado como Conselheiro do Rei Carlos V, da França. Nicolau Oresme dedicou-se a questões de filosofia política, das quais resultaram, entre 1355-1360, a produção de um trado de política monetária, conhecido como "De moneta". Segundo TURSI, nessa obra, Nicolau Oresme buscou, entre outras coisas, "establecer todo lo relativo a la política monetaria; fabricar moneda. Legislar sobre ella, ejecutar la legislación y observar el cumprimiento (caps. 5-21, passim), y lo que la comunidad decida es una 'cierta ley y firme ordenanza' (cap. 8). Incluso puede delegar en una persona pública, el príncipe, p.e., esa su función ejecutiva, reservándose para si la legislativa y de control. El príncipe, en este caso, es solo un ejecutor de una orden pública emanada de la comunidad (cap. 24). Este proceder es próprio, pues, de una comunidad que conoce sus derechos, naturalmente libre y que, por ello, nunca a sabiendas se sometería al yogo de un poder tiránico (cap. 24). (...) Brevemente, entonces, según el De moneta, hay en la comunidad una base privada de propietarios-trabajadores de desiguales recursos económicos. Gracias a esta desigualdad se da para Oresme una cierta armonía em la república, como en un coro se necesita una proporcionada y mesurada desigualdad de voces (cap. 25). Estos propietarios, por derecho natural, deciden y controlan sea ellos mismos sea sus representantes o su parte de mayor valia la legislación en política monetaria, la cual bien podría ser ejecutada por el príncipe. TURSI, Antonio D. La idea de representación en la obra política de Nicolas de Oresme. Veritas. Porto Alegre, vol. 43, no 3, set. 1998, p. 665-669.
} 
ingerência no sistema monetário perpetrada pelos governantes durante o período, o que resultava em constantes incertezas e inseguranças à economia local.

\section{3 - Idade Moderna}

Durante o período conhecido como Idade Moderna, LOCKE$^{72}$ e $\mathrm{HUME}^{73}$ elaboraram a "lei do valor da moeda", que estabeleceu relação direta entre o valor total da moeda em circulação e o montante dos bens passíveis de serem comercializados no interior do Estado. Posteriormente, RICARDO ${ }^{74}$ aperfeiçoou os ensinamentos desses autores, ao instituir a "teoria econômica quantitativa da moeda", relacionando os preços das mercadorias ao volume disponível da moeda.

Após a introdução de aspectos psicológicos, por VON WIESER ${ }^{75}$, na análise da relação entre as mercadorias e o volume disponível da moeda no mercado, e a consideração de fatores como: (i) o lapso de tempo necessário para o encadeamento dos movimentos de oferta e da demanda, capazes de promover o ajuste dos preços das mercadorias ao volume da moeda; e, (ii) as expectativas da população nacional, - a teoria

\footnotetext{
72 "Locke sucede a Hobbes como figura dominante da filosofia inglesa do século XVII. (...) Seria equívoco ver em Locke o simples precursor do empirismo associacionista de Hume. Porque, para Locke, se nosso saber começa pela experiência, desemboca sempre na razão; e inversamente, a razão encontra na experiência o fundamento de sua ascendência sobre o real e a garantia contra qualquer deriva metafísica verbal. A relação entre experiência e razão permite-nos compreender a passagem do Ensaio sobre o Entendimento Humano aos Dois Tratados sobre o Governo." HUISMAN, Denis. Dicionário dos filósofos. São Paulo: Martins Fontes, 2001, p. 604-610.

73 "David Hume is primarily known as a philosopher and chronicler of English history. Less well known is his work on economic theory and several political economy issues, some of which remain salient today. Studying his economic work enables us to see how he reshaped John Locke's quantity theory of money and how he influenced the great Adam Smith, Hume's close friend and fellow Scottish Enlightenment philosopher. Hume is one of the pillars of the classical school of economics, primarily founded by Smith. This issue of Economic Insights offers some of Hume's economic theorizing for those who want to pursue the intellectual history of modern economic theory." MCTEER, Bob. David Hume Foundations of the Classical School of Economics. Economic Insights. Federal Reserve Bank of Dallas, vol. 8, no 1, p. 10.

74 "Few ideas have been as widely accepted by economists and as roundly rejected by many other people as the doctrine of free international trade. Economists base their acceptance of the mutual benefits from such trade on a concept called comparative advantage. The theory is most closely associated with the writings of the great English classical school economist David Ricardo. Although his career in the field of political economy was brief, Ricardo became one of the most influential—and financially successful — practitioners the discipline has ever known." MCTEER, Bob. David Ricardo Theory of Free International Trade. Economic Insights. Federal Reserve Bank Of Dallas, vol. 9, n 2, p. 1.

75 “Menger's first important successor as an 'Austrian' economist was Friedrich von Wieser, who, beginning in 1884, published several books elaborating, rounding out, and refining Menger's theory of value, clarifying especially problems of cost, 'imputation', and distribution." HAZLITT, Henry. Understanding "Austrian" economics. Ideas on Liberty. October, 2003, p. 33. Disponível em: < http://www.fee.org/pdf/thefreeman/hazlitt1003.pdf>. Acesso em: 6 dez. 2008.
} 
quantitativa da moeda passou a ser considerada um dado fundamental para as equações do equilíbrio monetário.

Com a evolução dos estudos em torno da teoria quantitativa da moeda, verificouse que, para a configuração dos preços seria necessário não apenas as quantidades de metais disponíveis no mercado, na condição de reserva de valor, como também, os volumes de moeda-cunhada, de papel-moeda e de depósitos bancários efetuados.

\section{4 - Idade Contemporânea}

A partir da constatação da relação direta entre a quantidade da moeda em circulação e os preços das mercadorias e serviços disponíveis, a teoria quantitativa da moeda passou a se preocupar com os processos de construção dos meios de pagamento e suas conseqüências.

Os metais foram aceitos como meios de pagamento, tendo-lhes sido atribuído valor limitado e determinado, com base em sua capacidade de produção e extração na natureza. Assim, a moeda passou a existir e a circular na economia sob a forma cunhada e de "moeda-papel"76.

Conforme nos relata VIDIGAL, a moeda cunhada podia utilizar-se de um metal padrão, ou de outros materiais. Enquanto o metal padrão apenas modificava a composição dos quadros da moeda metálica, a moeda cunhada sob outros materiais representava um significativo acréscimo no montante dos meios de pagamento ${ }^{77}$.

A "moeda escritural", como será visto de forma mais aprofundada em tópico específico (tópico "2.5.5”, mais adiante, neste mesmo Capítulo), foi instituída pelo sistema bancário contemporâneo com a finalidade de concessão de créditos a empresários e consumidores, para que esses pudessem gerir e manter os seus negócios. De acordo com a

\footnotetext{
76 "O desenvolvimento seguinte no sistema de pagamentos foi o papel-moeda (pedaços de papel que funcionam como um meio de pagamento). Inicialmente, o papel-moeda incorporou uma promessa de que seria conversível em moedas ou em uma quantidade de metal precioso. Na maioria dos países, no entanto, o dinheiro evoluiu para papel-moeda sem lastro, papel-moeda decretado pelos governos como moeda corrente (significando que legalmente ele deve ser aceito como pagamento de dívidas) mas não conversível em moedas ou metal precioso. O papel-moeda tem a vantagem de ser muito mais leve do que moedas ou metalprecioso, mas só pode ser aceito como meio de pagamento se houver alguma confiança nas autoridades que $\mathrm{o}$ emitem e a impressão já alcançou um estágio suficientemente avançado, tornando a falsificação extremamente difícil. Como o papel-moeda evoluiu para um acordo legal, os países podem trocar o dinheiro que eles utilizam à vontade." MISHKIN, Frederic S. (2000) Op. cit., p. 33.

${ }_{77}$ VIDIGAL, Geraldo de Camargo. Disciplina dos órgãos de direção monetária. São Paulo, 1964, p. 25.
} 
demanda por crédito, este passou a ser fornecido pelos bancos sob a forma de um depósito correspondente, cuja função seria servir de lastro para a abertura de novos créditos ${ }^{78}$.

Após a Primeira Grande Guerra Mundial ${ }^{79}$, a Conferência Internacional de Bruxelas, ocorrida em 1920, recomendou a criação de um Banco Central em cada país, com a finalidade de restaurar e preservar a estabilidade monetária abalada pelo conflito bélico. Os membros da Conferência agiram sob a influência do Federal Reserve System ${ }^{80}$, responsável pelo fornecimento de créditos para a aquisição de armamentos e pelo financiamento das despesas provenientes da Primeira Guerra. Assim, foram criados Bancos Centrais em Estados que antes não o possuíam, a exemplo do Chile (1925), Equador (1927), Bolívia (1929), Turquia (1932) e Nova Zelândia (1935). No Brasil, o Banco Central $^{81}$ foi criado somente em 1965, após a experiência preparatória obtida nos anos de existência da Superintendência da Moeda e do Crédito (SUMOC), em $1945^{82}$.

Tendo os bancos centrais, desde sua origem, especial importância na regulação econômica através do controle da moeda, influenciando na própria evolução do conceito e na praticidade desse instrumento econômico, cabe atentar para seu processo formativo e para a estrutura que vieram a adquirir. O desenvolvimento histórico dos bancos centrais se confunde, em parte, com o da moeda. Sobre eles, VERÇOSA informa que:

(...) surgiram para emitir moeda, principalmente como contrapartida do desconto de letras de câmbio, para o fim de ajudar o comércio e a indústria. Mas seus fundadores não tiveram à época, a idéia de instituir um banco central como tal. Na sua história, não foram, sequer, os primeiros a emitir moeda e nem os únicos. ${ }^{83}$

\footnotetext{
${ }^{78}$ VIDIGAL, Geraldo de Camargo (1964). Op. cit., p. 26.

${ }^{79}$ A Primeira Guerra Mundial estendeu-se de 1914 até 1918.

${ }^{80}$ Sobre o Federal Reserve System, FRIEDMAN: The establishment of the Federal Reserve System was the most notable change in United States monetary institutions since at least the Civil War National Banking Act. For the first time since the expiration of the charter of the Second Bank of the United States in 1836, it established a separate official body charged with explicit responsibility for monetary conditions, and supposedly clothed with adequate power to achieve monetary stability or, at least, to prevent pronounced instability. Tradução livre: "O estabelecimento do Federal Reserve System foi a mais notável mudança nas instituições monetárias dos Estados Unidos desde pelo menos a Guerra Civil, com a Lei Bancária Nacional. Pela primeira vez desde a o fim da vigência da carta do Second Bank of the United States em 1836, foi estabelecido um órgão oficial autônomo com responsabilidade explícita pelas condições monetárias, e supostamente dotado de poder adequado para alcançar estabilidade monetária, ou, pelo menos, prevenir forte instabilidade”. FRIEDMAN, Milton. Op. cit., p. 44.

${ }^{81} \mathrm{O}$ Banco Central do Brasil, autarquia federal integrante do Sistema Financeiro Nacional, foi criado em 31.12.64, através da Lei n ${ }^{\circ} 4.595 / 64$.

${ }^{82}$ VERÇOSA, Haroldo Malheiros. Bancos centrais no direito comparado: o sistema financeiro nacional e o banco central do brasil (o regime vigente e as propostas de reformulação). São Paulo: Malheiros, 2005, p. 29-30

${ }^{83}$ Ibidem, p. 28.
} 
Continuando, afirma que:

Duas etapas foram superadas de maneira que tais organismos se caracterizassem como bancos centrais:

a) o reconhecimento da exclusividade do privilégio de emissão de moeda, assumindo a conversibilidade em ouro do papel-moeda em circulação, encerrando em seus cofres, por isso, a maior parte do estoque de metal precioso do seu respectivo país; e

b) a caracterização do perfil moderno dos bancos centrais, surgido de maneira plena apos a I Grande Guerra, quando se deixou de permitir aos portadores de papel-moeda a conversão automática e imediata em ouro, tomando-se o papel-moeda, por conseguinte, na moeda por excelência (I'ultime monnaie), estabelecendo-se que a moeda emitida por aquele banco era obrigatória no sistema nacional de pagamentos. ${ }^{84}$

Tem-se, assim, que (i) a adoção definitiva do papel-moeda como moeda por excelência; (ii) o tornar-se o papel-moeda emitido pelo banco em questão obrigatório no sistema nacional de pagamentos; e (iii) o reconhecimento da exclusividade do privilégio de emissão de moeda por parte desse banco vieram a constituir-se nos fatores formativos e determinantes da estrutura dos bancos centrais que nasceram desse processo.

É levando isso em conta que PATAT define bancos centrais como:

(...) organismos que eram já bancos do Estado e aos quais se concedeu o direito exclusivo de emitir moeda - tornado o meio de pagamento por excelência - deu-lhes um lugar preponderante no seio do sistema bancário, erigindo-os em bancos dos bancos. ${ }^{85}$ (Tradução livre de autoria de VERÇOSA)

Dessa forma, acrescentam-se às características já listadas as de serem os bancos centrais (iv) órgãos estatais que, por sua relevância, (v) passaram a ocupar posição hierárquica superior às demais instituições do sistema financeiro. No entanto, como não se pode deixar de mencionar que as funções dos bancos centrais também são fatores formativos e determinantes da estrutura de tais órgãos reguladores do sistema financeiro, cabendo, nesse aspecto, tecer as observações e esclarecimentos que se seguem.

Classicamente a função dos bancos centrais é garantir a estabilidade do valor da moeda, o que objetivam alcançar "harmonizando-se o nível adequado de aquisição de moeda

\footnotetext{
${ }^{84}$ Ibidem, p. 28-29.

${ }^{85}$ (...) organismes qui étaient déjà des banques de 1'Etat et à qui le droit exclusif d'émettre des billets, devenus les ultimes moyens de paiement, a donné une place préponderante au sein du systéme bancaire, les érigeant en banques des banques. PATAT, apud VERÇOSA. Op. cit., p. 36.
} 
no país pelos seus residentes, com o valor favorável do câmbio, para efeito do bom desenvolvimento do intercâmbio comercial" ${ }^{\prime 86}$.

Para tanto, servem como depositários de valor das reservas oficiais em ouro e moeda estrangeira, buscando o controle da base monetária, do comércio internacional, e de crédito perante a comunidade financeira internacional. A título de exemplo, entre essas práticas pode-se encontrar a atuação no mercado aberto, a manipulação da taxa de juros no redesconto de títulos, as limitações ao crédito, o depósito compulsório, entre outros. Além disso, precisam praticar políticas restritivas quanto aos bancos, a fim de impedir a criação livre de moeda escritural.

Quanto às funções dos bancos centrais quando em relação com os bancos a eles subordinados, resume VERÇOSA:

(...) os bancos centrais exercem competência normativa, preventiva, fiscalizadora e repressiva delegada (na área administrativa e dentro dos limites determinados em lei), autorizando o funcionamento dos bancos; regulando e fiscalizando suas atividades; e julgando os atos irregulares e aplicando as penalidades cabíveis. ${ }^{87}$

Feitos os devidos esclarecimentos, clara fica a importância dos bancos centrais para a adoção e manutenção do papel-moeda como moeda por excelência. Aliás, são os bancos centrais instituições que devem sua razão de ser à gerência possibilitada pela fluidez e impactos econômicos do papel-moeda no mercado. Compreende-se, pois, os efeitos que seu surgimento ocasionou nas noções e aplicações da moeda no período posterior à I Grande Guerra, o que possibilita a continuação devida do estudo histórico estrito da evolução da moeda, tendo como enfoque o âmbito mundial.

Especialmente após a Segunda Guerra Mundial, as relações comerciais, financeiras e monetárias entre os Estados e as empresas multilaterais e transnacionais foram aperfeiçoadas. Com o aumento da interdependência entre as nações, a moeda passou a ser, manifestamente, o principal instrumento a mediar as relações socioeconômicas entre os povos.

Conforme assinala NASSER ${ }^{88}$, dentre os fatores de estímulo à interdependência entre as nações no século XXI, encontram-se:

\footnotetext{
${ }^{86}$ Ibidem, p. 39.

${ }^{87}$ Ibidem, p. 72.

${ }^{88}$ NASSER, Rabih Ali. A OMC e os países em desenvolvimento. São Paulo: Aduaneiras, 2002, p. 76 apud WORLD TRADE ORGANISATION. International trade statistics 2000. Geneva, 2000, p. 28.
} 
(i) o aumento do fluxo comercial de mercadorias e serviços entre os países; ${ }^{89}$

(ii) o aumento dos fluxos financeiros, na forma de investimentos diretos (produtivos ou especulativos) ou empréstimos, seja diretamente entre os países, entre agentes privados (instituições financeiras, empresas multinacionais e transnacionais) e os países, ou dos organismos internacionais surgidos com os Acordos de Bretton Woods para os países, principalmente os menos desenvolvidos;

(iii) a adoção quase generalizada a partir da década de 80 de políticas de liberalização econômica pelos países em desenvolvimento e pelos países integrantes do bloco comunista (incluindo a abertura às importações e aos investimentos estrangeiros, o abandono das medidas de proteção à indústria nacional, como a política de substituição de importações, entre outras ${ }^{90}$.

Assim, para NASSER ${ }^{91}$, o ingresso de recursos em nosso país, em elevado montante nos últimos anos, está diretamente vinculado a fatores como a exigência de proteção a esses investimentos, o que significa para o Brasil e para os demais países receptores dos investimentos, a adoção de normas jurídicas adequadas, capazes de assegurar aos investidores uma segurança de expectativas com relação à propriedade do seu investimento e dos conseqüentes frutos da aplicação no país.

Nesse sentido, VERÇOSA traz contribuição relevante ao asseverar que:

(...) é extremamente importante a existência de mercados financeiro e de capitais fortes e organizados, a partir da estruturação dos sistemas próprios, objetivo que, entre nós, foi iniciado com a reforma bancária de 1964 (Lei no 4.595/1964), organizadora do Sistema Financeiro Nacional (SFN); com a edição da chamada Lei do Mercado de Capitais (Lei $\mathrm{n}^{\circ}$ 4.728/1965); e com a criação da Comissão de Valores Mobiliários (CVM) e substituição da lei das sociedades anônimas por outra mais moderna (Leis ns. 6.385/76 e 6.404/76, esta modificada posteriormente pelas Leis ns. 9.447, de 5.5.1997 e 10.303, de 31.10.2001) ${ }^{92}$.

\footnotetext{
${ }^{89}$ Segundo dados fornecidos por Ali Nasser, a evolução do total de importações e exportações no mundo, durante os últimos 50 anos, bem demonstra o aumento da interdependência entre as nações. Com base em relatório fornecido pela Organização Mundial do Comércio (OMC), em 2000, relata: "As exportações evoluíram da seguinte forma (sempre em bilhões de dólares): 83 em 1953; 157 em 1963; 578 em 1973; 1.835 em 1983; 3.639 em 1993 e 5.473 em 1999. As importações tiveram aumento equivalente: 84 em 1953; 163 em 1963; 589 em 1973; 1.880 em 1983; 3.752 em 1993 e 5.729 em 1999." Acrescentamos que, para a concretização de tais importações e exportações - fenômenos estes que, somados a tantos outros aspectos decorrentes da globalização econômica, desconhecem distâncias físicas -, a moeda é o principal instrumento monetário e financeiro utilizado, seja como meio de troca, como reserva de valor, ou como meio para o financiamento de investimentos estrangeiros nos países em desenvolvimento e de menor desenvolvimento relativo.

${ }^{90}$ NASSER, Rabih Ali (2002). Op. cit., p.76.

${ }^{91}$ Idem.

${ }^{92}$ VERÇOSA. Op. cit., p. 42.
} 
Com o intuito de propiciar um melhor desenvolvimento econômico interno e um aumento da confiança e segurança dos investimentos estrangeiros no país, no entanto, o Brasil vem promovendo uma progressiva liberalização e flexibilização das normas do Conselho Monetário Nacional ${ }^{93}$ e do Banco Central do Brasil, em matéria de registro de empréstimos ou investimentos estrangeiros e sua repatriação. Nessa direção, foi aprovada a Resolução n ${ }^{\circ}$ 2.770, de 30 de agosto de 2000, do Banco Central do Brasil, com o fim de alterar e consolidar as normas sobre as operações de empréstimos estrangeiros.

Assim, também, tantos outros países e blocos econômicos vêm agindo na seara econômica interna e internacional, no sentido de promover o seu desenvolvimento econômico interno e aperfeiçoar a sua inserção no mercado internacional. Aliam a produção normativa nacional, e a adesão a tratados e a acordos internacionais, aos seus interesses comerciais, monetários e financeiros, decorrentes das políticas econômicofinanceiro-monetárias seguidas pelo Sistema Financeiro Nacional e pelo Banco Central nacional.

\section{5 - Instrumentos Utilizados como Moeda}

Em razão do aumento da complexidade das negociações comerciais intra e extrafronteiras, as relações de compra e venda de bens e serviços, entre nacionais e estrangeiros, passaram a necessitar de uma maior sustentabilidade econômica e aparato normativo para serem empreendidas. Assim, surgiu a necessidade da construção de sistemas monetários, estruturados em pilares econômicos e jurídicos, com o fim de assegurar a manutenção das negociações e oferecer segurança às partes envolvidas.

A segurança jurídica e a previsibilidade normativa configuram princípios basilares da teoria geral do direito, e são constitucionalmente protegidos pela Constituição brasileira de 1988, em seu artigo 5 $5^{\circ}$, caput e incisos. Entretanto, em se tratando de sistema monetário, e propriamente, de um sistema econômico de mercado, em que a moeda configura o instrumento fundamental de trocas, de pagamentos e de transações financeiras, a “incerteza" representa o elemento basilar que permeia todas as relações monetárias.

\footnotetext{
${ }^{93}$ O Conselho Monetário Nacional (CMN) é o órgão deliberativo máximo do Sistema Financeiro Nacional e foi criado pela Lei $\mathrm{n}^{\circ}$ 4595, de 31 de dezembro de 1964.
} 
A moeda perfaz, assim, o elemento de redução das incertezas do sistema monetário e financeiro, pois, possibilita o cumprimento das obrigações pecuniárias assumidas, representando o meio de pagamento. Conforme consigna SANT'ANA "a moeda é um ativo cuja própria existência depende da incerteza e dos custos de transação. $\mathrm{O}$ uso da moeda como meio de pagamento permite que as transações nas quais ela é usada sejam finais" $" 94$.

O elevado grau de incerteza presente nas economias de mercado decorre da falta de informações sobre os agentes atuantes nas negociações. Com efeito, a utilização da moeda confere às relações econômicas o grau de segurança e confiabilidade que lhes faltava. Como bem examina SANT'ANA:

\begin{abstract}
Na medida em que a economia se desenvolve, as transações monetárias aumentam porque também aumenta a falta de informação sobre os compradores. As transações monetárias declinarão na medida em que haja mais informação. Cartões de crédito, cheques especiais, cartões de garantia de cheques etc. são instrumentos que aumentam as informações e reduzem as incertezas; portanto levam à redução nas transações que usam papel-moeda. Daí que, na medida em que aumentam as informações sobre os agentes, há uma redução das incertezas e, portanto, um declínio no uso da moeda como meio de pagamento ${ }^{95}$.
\end{abstract}

A moeda é, portanto, essencialmente um fator de segurança, mas que pode ser preterida quando idealizada sob a forma de papel-moeda, em razão do aumento das informações disponibilizadas na atualidade através dos mais diversos mecanismos, como os bancos de dados e as informações digitais de segurança que mais facilmente identificam os agentes, dando-lhes credibilidade nos negócios de forma global.

\title{
2.5.1 A Moeda-Mercadoria
}

Conforme já referido, em um primeiro momento, mercadorias como tecidos, utensílios domésticos, gado, sal, e outros elementos materiais, exerceram o papel de moeda na economia, cumprindo, assim, algumas das funções inerentes a ela, como a de meio de troca e de unidade de pagamento. A moeda-mercadoria, como foi denominada, tinha por finalidade garantir a manutenção das trocas indiretas entre os cidadãos e grupos de comerciantes, nacionais e estrangeiros.

\footnotetext{
${ }^{94}$ SANT'ANA, José Antonio (1997). Op. cit., p. 19.

${ }^{95}$ Idem.
} 
O "valor de uso" da moeda-mercadoria, decorrente de sua utilidade e da capacidade de atender às necessidades dos indivíduos, e o seu caráter material, pouco a pouco foram perdendo espaço, e sendo substituídos por uma moeda que priorizava o seu "valor de troca", - um aspecto desmaterializado -, e a aceitabilidade generalizada da sociedade.

Há evidências de que as moedas-mercadorias foram utilizadas não só na Idade Antiga, como também na Idade Média e na Idade Moderna, conforme estudos efetuados por LOPES e ROSSETTI ${ }^{96}$. De acordo com os autores, durante a Idade Antiga, regiões como o Egito, a Babilônia, a Assíria, a Líbia, a Pérsia, a Bretanha, a Índia e a China utilizaram como moedas-mercadorias os seguintes bens: cobre, prata, cevada, peças metálicas cunhadas, gado bovino e ovino, barras de ferro, espadas de ferro, escravos, animais domésticos, arroz, ouro, conchas, seda, metais, instrumentos agrícolas, cereais e sal.

Durante a Idade Média, localidades como as Ilhas Britânicas, a Alemanha, a Islândia, a Noruega, a Rússia, a China e o Japão adotaram como moedas-mercadorias: moedas de couro - precursoras das cédulas de papel -, gado, ouro, prata, cereais (sobretudo aveia e centeio), mel, moedas cunhadas em ouro e prata, tecidos, manteiga, pele curtida, peixes secos, peles de esquilo, arroz, chá, estanho, pérolas e ágatas ${ }^{97}$.

Nesse diapasão, durante a Idade Moderna, os Estados Unidos da América (EUA), a Austrália, o Canadá, a França, a Alemanha, a Áustria, e o Japão, adotaram em seu comércio as seguintes moedas-mercadorias: fumo, cereais, carnes-secas, madeira, gado, rum, trigo, pele de animais, a terra, o arroz, e warrants - quando emitidos pelo depósito de $\operatorname{arroz}^{98}$.

Apesar da utilização da moeda-mercadoria em tempos mais recentes, e por civilizações com elevado grau de desenvolvimento sócio-econômico, conforme apontado por LOPES e ROSSETTI, não havemos de discordar que esta modalidade de moeda alcançou sua plenitude de utilização na Idade Antiga, em que as trocas compunham a base de sustentação das relações comerciais.

Concordamos, no entanto, com os autores sobre as razões que levaram à substituição da moeda-mercadoria por outras formas de moeda, como por exemplo, a confusão gerada a partir da relação muito próxima entre o "valor de uso" e o "valor de

\footnotetext{
${ }^{96}$ LOPES, João do Carmo; ROSSETTI, José Paschoal. Op. cit., p. 30.

${ }^{97}$ Idem.

${ }^{98}$ LOPES, João do Carmo; ROSSETTI, José Paschoal. Op. cit., p. 31.
} 
troca" da moeda, o que acabou por prejudicar a sua credibilidade e aceitação como instrumento de troca, pois, a partir do momento em que a moeda era utilizada como bem de consumo ou instrumento de trabalho, as relações se assemelhavam ao escambo.

Por fim, segundo os mesmos autores enfatizam, a confiança sobre a moeda era prejudicada nas situações em que: (i) o tempo destruía as características essenciais do produto; (ii) o instrumento era de difícil manuseio ou transporte; e, (iii) quando se notava a facilidade com que a moeda poderia ser divisível ou transferível a outrem ${ }^{99}$.

\subsubsection{A Moeda Metálica}

Diante da multiplicação do número de intercâmbios comerciais entre nacionais europeus e cidadãos estrangeiros, a utilização da moeda como intermediadora das trocas e unidade de valor se tornou aceita universalmente. No entanto, os inconvenientes percebidos ao longo das negociações e trocas, em razão da utilização da moedamercadoria, incentivaram os Estados a buscarem uma nova modalidade de instrumento monetário para ser utilizado como unidade de valor.

Este novo instrumento deveria, no entanto, ser capaz de atender às necessidades condizentes com o crescimento do comércio: (i) ser aceito pela população; (ii) ser de fácil transporte e manuseio; e (iii) ser escasso no mercado, para garantir a sua permanente valorização.

Por todos esses motivos, aliados ao preenchimento dos requisitos necessários a uma unidade de valor, e, inclusive, devido à possibilidade de um maior controle por parte dos governantes sobre as emissões de moeda, os metais se tornaram o objeto preferido dos comerciantes e do próprio Estado, que, por meio do processo de cunhagem, os transformavam em moeda, com peso e volume predefinidos.

Para o governo, não havia solução melhor, capaz de conciliar os seus anseios às necessidades da população. Como se não bastasse tamanha descoberta, a moeda cunhada ainda possibilitou aos governantes a cobrança de tributos sobre o processo de cunhagem. Durante a Idade Média, os senhores feudais monopolizaram o processo de cunhagem e de atribuição de valor à moeda, uma prática denominada "senhoriagem"100, que lhes garantiu um aumento de suas próprias riquezas.

\footnotetext{
${ }^{99}$ Ibidem, p. 29.

100 “(...) não há na literatura uma definição clara do conceito moderno de senhoriagem. (...) ora é definida como o lucro do governo derivado da emissão de moeda, ora como a receita do governo resultante do poder
} 
Os primeiros metais a serem cunhados e a circular como moeda foram o cobre, o bronze e o ferro. Mas, devido à abundância na natureza e ao fácil acesso a quaisquer pessoas, o potencial de reserva de valor desses metais restou comprometido, e logo o governo iniciou um processo de substituição por outros metais.

Desta vez, o ouro e a prata foram os metais escolhidos, devido a sua escassez, preciosidade e aceitação irrestrita pela população. Ademais, o ouro e a prata sempre foram considerados metais nobres, e a sua posse desde os tempos mais remotos já denotava prestígio, riqueza e prosperidade àqueles que os detinham em seu poder.

\subsubsection{A Moeda-Papel}

A utilização da moeda metálica se alastrou entre os comerciantes, adquirindo ampla respeitabilidade e aceitação nas feiras de comércio européias, e em especial, nas feiras italianas. Naquele período, o comércio florescia na região norte da Itália, em meio às conhecidas feiras instauradas após o Renascimento, nas cidades italianas e nas regiões de Flandres e de Champagne.

Com o rompimento das fronteiras entre os Estados, e até entre os continentes, como fruto das grandes navegações e da política colonialista de importação e exportação de mercadorias, a moeda passou a circular como instrumento monetário internacionalmente reconhecido e aceito.

Mesmo diante da irrestrita aceitação da moeda-metálica, com a multiplicação das viagens de longa distância e a constante necessidade de transportar elevados volumes de moeda, sob riscos de roubo durante as viagens, com o tempo, os governos passaram a buscar uma nova forma para a representação monetária. O novo instrumento deveria

de monopólio de emissão de moeda. Dada essa falta de definição clara, as pessoas são tentadas a estabelecer uma analogia entre o conceito moderno de senhoriagem (que seria apropriado à nova concepção de moeda fiduciária) com o conceito de taxa de senhoriagem vigente na Idade Média (apropriado à concepção de moeda mercadoria). De fato, a taxa de senhoriagem podia ser calculada, naquela época, como a diferença entre o valor de face da moeda e o custo do metal utilizado na cunhagem, menos o custo de produção. Como a moeda fiduciária não tem valor intrínseco, a senhoriagem é definida, então, simplesmente como o aumento do volume de moeda doméstica menos o custo de produção (geralmente insignificante). Por outro lado, podemos considerar que o uso de papel moeda em lugar de moeda intrínseca gera uma poupança social muito grande no uso dos recursos que, de outra forma, deveriam ser gastos na mineração e fundição de grandes quantidades de metal. Essa poupança, medida considerando a curva de demanda agregada por moeda em função da taxa de juros, também pode ser definida como senhoriagem. Assim, o custo social de manter moeda é medido pelo custo de oportunidade dos recursos utilizados para produzir moeda. É também freqüente a associação entre senhoriagem e imposto inflacionário, ou seja, a senhoriagem seria o rendimento real que o Estado obtém através da inflação (Lipietz [1991]). Dito de outra forma, a inflação é uma forma de tributação, é um imposto sobre a manutenção de encaixe monetário (Mankiw [1987])." Cf. Senhoriagem e financiamento do setor público no Brasil. Disponível em: <http://www.tesouro.fazenda.gov.br/ Premio_TN/XIPremio/divida/MHafdpXIPTN/mh_premio_afdp.pdf>. Acesso em: 12 nov. 2008. 
agregar os benefícios concentrados no metal, e ainda ser capaz de oferecer maior segurança aos usuários, maior flexibilidade aos inconvenientes trazidos pela moeda-metálica, e não deter um peso tão elevado quanto o metal - que passou a ser considerado um verdadeiro inconveniente nas viagens de longa distância.

Deste modo, em meio às tentativas para solucionar a questão, os comerciantes passaram a deixar os metais preciosos em lugares que mais tarde receberam o nome de “Casas de Custódia", responsáveis por armazenar, sob garantia, os valores monetários depositados sob a sua guarda.

A moeda negociada nas feiras de comércio era, em grande parte, depositada nas casas bancárias italianas, ou "Casas de Custódia", em troca dos chamados "Certificados de Depósito", entregues pelos bancos aos depositantes, como garantia do ouro e da prata custodiados. Por representarem uma garantia documental dos valores armazenados nos bancos, tais certificados passaram a circular como verdadeiros instrumentos de valor. Como decorrência da confiabilidade que adquiriram por parte da sociedade, em especial, e dos comerciantes, transformaram-se na nova moeda, desta vez uma de papel, ou a "moedapapel", como ficou conhecida ${ }^{101}$.

Em conformidade com o relato de LOPES e ROSSETTI, a moeda-papel detinha um lastro de $100 \%$, e garantia de plena conversibilidade, uma vez que aos seus detentores era facultada a troca, a qualquer tempo, dos certificados pelo montante de metais preciosos armazenados nas casas bancárias, o que lhes conferia uma ampla credibilidade ${ }^{102}$.

Nesse contexto, uma nova modalidade de moeda passou a circular no mercado, conquistando a confiança geral e suprindo as deficiências localizadas nos metais preciosos.

\subsubsection{A Moeda Fiduciária ou "Papel-Moeda"}

A moeda fiduciária, ou simplesmente, "papel-moeda", originou-se a partir da percepção das casas bancárias ${ }^{103}$ de que todas as garantias oferecidas aos depositantes, como a total conversibilidade dos "certificados de depósito" no montante equivalente ao ouro e à prata depositados, e, o lastro integral da moeda metálica, - eram desnecessárias para assegurar a confiabilidade dos certificados, ou da moeda-papel, como instrumento monetário em circulação.

\footnotetext{
${ }^{101}$ LOPES, João do Carmo; ROSSETTI, José Paschoal. Op. cit., p. 32.

102 Ibidem, p. 33.

${ }^{103}$ As casas bancárias, ou "Casas de Custódia" eram verdadeiros armazéns destinados à guarda e proteção da moeda-metálica em ouro e prata.
} 
Nesse sentido, graças à conquista da confiança da população, novamente se fez possível adotar um instrumento diverso daqueles existentes para desempenhar a função de moeda. A nova unidade de valor, emitida pelas casas bancárias em forma de "certificados", passou a não dispor da garantia de conversibilidade absoluta e imediata, e a não contar com lastro integral (100\%), com relação ao montante de ouro e prata armazenados.

Os bancos chegaram, inclusive, a emitir certificados destituídos de qualquer lastro, tamanha a credibilidade da população sobre o novo instrumento monetário. Assim, surgiu a "moeda fiduciária", ou "papel-moeda", em substituição à "moeda-papel", modalidade de moeda representativa.

As emissões de papel-moeda, no início, eram efetuadas por bancos particulares, mas, posteriormente, o seu monopólio foi transferido ao Estado, devido à falência do sistema monetário e financeiro, por ocasião da emissão sem lastro e sem limite de papelmoeda.

Com a função de controlar as emissões, o Estado adotou três sistemas distintos:

(i) o Sistema de Cobertura Integral, em que as emissões eram equivalentes ao montante do encaixe da moeda, adotado inicialmente na Inglaterra e, a partir de 1874, nos EUA;

(ii) o Sistema de Reserva Proporcional, em que havia certo equilíbrio na paridade "emissão versus encaixe da moeda". Nesse caso, o percentual variava de acordo com o sistema monetário adotado pelo país, chegando a alcançar 30\% na Alemanha e na Bélgica, e 40\% na Itália, Suíça e nos EUA e Holanda ${ }^{104}$; e por fim;

(iii) o Sistema de Teto Máximo, baseado no estabelecimento de um teto máximo de emissão, sem relação com o encaixe metálico. Adotado na França, foi considerado o sistema mais flexível e apto para lidar com as necessidades de emissão monetária.

Os três sistemas de emissão de moeda foram seguidos por diversos países, em especial durante períodos de guerra e crises financeiras. Após a I Guerra Mundial, com base na preocupação de resgatar a conversibilidade do papel-moeda, instituíram-se dois sistemas distintos dos anteriores:

\footnotetext{
${ }^{104}$ Cabe observar que o nome oficial (e correto) é Reino dos Países Baixos (ou, resumidamente, Países Baixos). Entretanto, em razão do uso mais popular e generalizado, adota-se, neste estudo, ao nos referirmos àquele país, a denominação Holanda, que, na verdade, se refere a duas províncias (Holanda do Norte e do Sul).
} 
a) o Gold exchange standard: responsável pela garantia da conversibilidade do papel- moeda em uma moeda estrangeira que fosse conversível em ouro; e,

b) o Gold bullion standard: sistema em que o papel-moeda foi convertido em lingotes de ouro, não utilizáveis para pagamentos internos, e sim passíveis de serem entesourados.

Malgrado os esforços para controlar as emissões e a conversibilidade do papelmoeda, com a crise do café, compreendida entre 1929 e 1933, ambos os sistemas de conversão da moeda extinguiram-se, tendo sido abandonada a idéia da conversão. As moedas nacionais deixaram de ter as garantias do lastro em ouro e em prata, e os sistemas monetários passaram a ser fiduciários. Apenas os EUA mantiveram o lastro-metálico por mais tempo, até o ano de 1971.

Ainda hoje, em distinta configuração e aparência, o papel-moeda exerce as funções de meio de pagamento, instrumento de valor, e de meio de troca, inerentes aos instrumentos monetários, sendo um dos meios mais utilizados nas transações econômicas, por deter o maior grau de aceitabilidade pela sociedade sobre qualquer outro instrumento monetário. Sua aceitação é inquestionável, em qualquer local do globo. Atualmente, os sistemas monetários emitem o papel-moeda sem lastro metálico, e sem conversibilidade.

\subsubsection{A Moeda Bancária ou Escritural}

A moeda bancária surgiu para circular paralelamente à moeda fiduciária. Instituída por bancos comerciais, representa o total de depósitos à vista e a curto prazo efetuados por clientes. Por configurar apenas um valor de troca, ou um meio de prestação de serviços, e ser desmaterializada ${ }^{105}$, é também denominada "moeda invisível".

É ainda concebida como uma moeda escritural, por representar lançamentos futuros a débito e a crédito, registrados nas contas correntes. Seu valor é mensurado de acordo com sua liquidez, e sua movimentação ocorre por meio da emissão de cheques ou de ordens de pagamentos.

A moeda bancária, ou escritural, é considerada o meio de pagamento mais utilizado atualmente em todos os países.

\footnotetext{
105 “Aujourd'hui, la monnaie s'est complètement dématérialisée, sauf dans les relations internationales où la dématérialisation n'est que partielle. Sa valeur tient essentiellement à son pouvoir libératoire, confirmé par une decision de la puissance publique et entraînant son acceptation générale par la collectivité. Elle repose ainsi sur une notion juridique doublée d'un phénomène social'". Cf. BERGER, Pierre. La monnaie et ses mécanismes. Presses Universitaires de France. 6. ed., 1975, 13.
} 


\section{6 - O Sistema Monetário Internacional e sua relação com o Ouro e as Moedas Nacionais}

\subsubsection{Conceito}

O Sistema Monetário Internacional ${ }^{106}$ é o conjunto de regras, costumes, instrumentos e organizações que visam regulamentar as relações entre Estados, mercados e moedas ${ }^{107}$. Trata-se de um conjunto de regras comerciais e cambiais estabelecidas em consenso pelos países integrantes do Fundo Monetário Internacional (FMI), criado em 1944, na conferência de Bretton Woods.

As características do sistema monetário internacional (SMI) em cada período da história são: a forma da moeda internacional; o regime de câmbio; e o grau de mobilidade dos capitais $^{108}$.

$\mathrm{Na}$ verdade, a Conferência de Bretton Woods foi o nome pelo qual ficou conhecida a Conferência Monetária e Financeira das Nações Unidas, realizada em julho de 1944, em Bretton Woods, New Hampshire, Estados Unidos, com representantes de 44 países, para planejar a estabilização da economia internacional e das moedas nacionais que haviam sido prejudicadas pela Segunda Guerra Mundial. Os acordos assinados na Conferência tiveram validade para o conjunto das nações capitalistas lideradas pelos Estados Unidos, resultando na criação do Fundo Monetário Internacional - FMI, e do Banco Internacional de Reconstrução e Desenvolvimento - BIRD. Pelo acordo, procurouse ordenar o sistema monetário internacional por meio da conversibilidade do dólar em ouro, à razão de US\$ 35 por onça troy, $31,1 \mathrm{~g}^{109}$. Os demais signatários fixariam as paridades de suas moedas em relação ao dólar ${ }^{110 .}$

\footnotetext{
106 "O sistema monetário internacional consiste em um sistema de regras e convenções que governam as relações financeiras entre os países. Pode ser identificado por três características-chave: a maneira pela qual um mercado de câmbio é organizado, os tipos de ativos usados para financiar ou liquidar desequilíbrios de pagamentos entre países e o mecanismo de ajuste a déficits e superávits de pagamento, o chamado problema da consistência." MENDES, Lívia. Do padrão ouro a Bretton Woods: algumas considerações. Brasília: UNB, 2005. INTRODUÇÃO.

${ }^{107}$ SALVATORE, Dominick. Economia Internacional. 6. ed. Rio de Janeiro: LTC Editora S.A., 2000, p. 430.

${ }^{108}$ PRATES, Daniela. As assimetrias do sistema monetário e financeiro internacional. Revista Economia Contemporânea, Rio de Janeiro: maio/ago 2005, p. 265.

109 "A afirmação dos Estados Unidos como potência hegemônica do capitalismo, transfere para o Dólar norte-americano essa função, cristalizada na famosa conferência de Bretton Woods em 1944, na qual foram estabelecidas regras para o funcionamento no sistema financeiro internacional. Na conferência foi estabelecido o padrão-ouro (US\$ 35 a onça troy) e as demais moedas dos países signatários (44, entre eles o Brasil) teriam uma paridade referencial em relação à moeda norte-americana. Para lastreá-la, os Estados Unidos se comprometiam a manter uma quantidade de ouro equivalente à quantidade de dólar em
} 
O Acordo de Bretton Woods objetivou estabelecer um regime monetário internacional capaz de evitar as instabilidades econômicas dos períodos anteriores. Almejou criar um sistema cambial com taxas fixas das moedas nacionais em relação ao ouro ou dólar; zelar pelo funcionamento das novas regras; e fomentar o comércio internacional.

\subsubsection{FMI (Fundo Monetário Internacional)}

O órgão criado com o intuito de ser responsável pelo bom funcionamento das novas regras adotadas no Acordo de Bretton Woods foi o Fundo Monetário Internacional (FMI).

Dentre os objetivos do FMI, merecem destaque: a promoção da cooperação monetária internacional; a facilitação da expansão e o crescimento equilibrado do comércio internacional; e a promoção da estabilidade comercial. O Acordo de Bretton Woods, assinado em 1944, atribuiu ao FMI a gestão do sistema de taxas fixas de câmbio adotado no acordo ${ }^{111}$.

No entanto, a suspensão, por parte dos Estados Unidos, da conversão de sua moeda, o dólar em ouro, levou ao fim o Acordo de Bretton Woods. As conseqüências do fim desse acordo foram muito negativas com relação à estabilidade monetária. Entretanto, na área comercial, os países desenvolvidos se asseguraram de melhores condições e benefícios em detrimento dos países em desenvolvimento.

A posição do dólar como moeda-chave consolidou-se, após o colapso de Bretton Woods, com o poder financeiro dos Estados Unidos associado à importância das instituições financeiras americanas e à dimensão do seu mercado financeiro interno. ${ }^{112}$

circulação." CHELALA, Charles. Política cambial e mercado de moedas na virada do século. Movendo Idéias, Belém, vol. 5, n . 8, dez. 2000, p. 39-44.

${ }_{110}$ Cf. GAROFALO FILHO (2004). Op. cit., p. 37.

111 "O FMI serviria para manter o novo Sistema Financeiro funcionando, provendo empréstimos para os Estados conseguirem manter o novo padrão cambial adotado. Esses empréstimos eram de curto prazo, para sanar problemas específicos do balanço de pagamentos, mas em vista das dificuldades que todas as nações passavam na época da realização da Conferência, foi requisitada também a criação de um organismo que financiasse o desenvolvimento econômico. Com esse fim seria criado o Banco Internacional de Reconstrução e Desenvolvimento (BIRD), um organismo que ofereceria empréstimos de longo prazo para financiar projetos de desenvolvimento que no futuro, em conjunto com outros organismos, formariam o Grupo Banco Mundial." ROMMINGER, Alfredo. O Grupo Banco Mundial: origem, funcionamento e a influência do desenvolvimento sustentável em suas políticas. Universitas - Relações Int., Brasília, vol. 2, nº 1, p. 269-288, jan./jun. 2004, p. 272.

${ }_{112}$ HELLEINER, E. States and the reemergence of global finance: from Bretton Woods to the 1990's. Ithaca e Londres: Cornell University Press, 1994, p. 137. 
Atualmente, o Fundo Monetário Internacional é composto por 182 PaísesMembros, que possuem cotas-partes. O poder de cada país dentro do órgão é determinado pelo valor de sua quota-parte, ou seja, quanto maior sua quota-parte, maior será seu poder de voto e veto. O Brasil é um dos países fundadores do FMI, e o Presidente do Banco Central substitui o Ministro da Fazenda, nos casos de ausência desse, como governadorrepresentante do FMI.

Nas últimas três crises mundiais, sem contar a atual, o FMI atuou concedendo recursos financeiros. Por ocasião da crise asiática, os principais países daquele continente possuíam, como principal parceiro comercial, o Japão. Em 1996, esses países alinharam suas moedas ao dólar dos Estados Unidos, sofrendo com isso uma depreciação em decorrência da desvalorização da moeda estadunidense e da moeda chinesa. Houve uma crise nos sistemas financeiros em decorrência da falta de credibilidade gerada pelas desvalorizações competitivas das diversas moedas, propiciando a atuação do FMI como fornecedor de empréstimos aos diversos Estados.

Quando o colapso da Rússia, em decorrência da crise internacional, se agravou, a desconfiança se generalizou e o mercado financeiro se afastou daquele país que não conseguiu honrar seus compromissos internacionais. O FMI, em conjunto com o Banco Mundial e o Japão, costurou, então, um pacote que incluía um empréstimo de 22,6 bilhões de dólares dos Estados Unidos.

Ainda, como conseqüência dessas crises, ocorreu uma terceira, localizada, desta vez, na América Latina, agravada, ainda mais, com a saída de capitais. O FMI atuou, nessa ocasião, como nos demais casos, determinando políticas econômicas extremamente recessivas, como condicionante dos empréstimos concedidos.

Merece ser lembrado aqui que, da mesma forma, no âmbito do Acordo de Bretton Woods, em 1944, foi criado o Banco Mundial ${ }^{113}$, com a função, dentre outras, de ofertar capitais de longo prazo, em especial no financiamento de projetos de desenvolvimento econômico.

\footnotetext{
113 “A definição do Banco Mundial é um pouco fora do convencional, já que ele não é um banco no sentido usual da palavra. Essa dificuldade conceitual foi identificada já na época dos debates em Bretton Woods. Naquela ocasião, os delegados dos 44 países não sabiam como nomear tal instituição, mas aparentemente todos achavam adequado omitir a palavra "banco", pois o Banco tinha características mais comuns a um fundo. O Banco Mundial não é realmente um banco, faltam a ele diversas funções ordinárias que cabem a um banco cumprir, como receber depósitos dos seus associados. O que ele faz é oferecer empréstimos a governos, ou a entidades privadas garantidas pelos governos, além disso, seus empréstimos são oferecidos a juros inferiores aos de mercado e não são direcionados a países com condições de fazer empréstimos em termos razoáveis de outras fontes.” ROMMINGER. Op. cit., p. 274.
} 
O Banco Mundial foi uma resposta à necessidade de reconstrução européia no pós Segunda Guerra Mundial. Contudo, os países mais pobres participantes da conferência argumentaram que o Sistema Financeiro Internacional também deveria oferecer condições que promovessem o seu desenvolvimento. Assim, o Banco Mundial deixou de ser uma instituição voltada para reconstrução européia, dedicando-se principalmente à promoção do desenvolvimento e eliminação da pobreza mundial ${ }^{114}$.

\subsubsection{O Ouro}

\subsubsection{Características}

Este metal precioso, amarelo e brilhante, cuja densidade é de $19,3 \mathrm{~g} / \mathrm{cm}^{3}$, é utilizado para fabricação de moedas, ornamentos, jóias e de ampla utilização odontológica e industrial. Metal nobre por excelência, seu ponto de fusão é de $1.064^{\circ} \mathrm{C}$, podendo atuar como condutor de eletricidade ${ }^{115}$.

Explica-se sua classificação como metal precioso devido ao fato de não reagir à maioria dos agentes químicos, o que aumenta consideravelmente a sua durabilidade, tornando-o um metal que pode ser transformado e armazenado sem a perda de suas características. Por este motivo é utilizado na cunhagem de moedas e em ourivesaria.

\subsubsection{Histórico}

O ouro é utilizado com moeda desde as épocas mais remotas. As primeiras cunhagens conhecidas datam da época dos reis da Lídia (568 a.C.). A purificação do ouro consiste no processo de separar o metal das impurezas ou ligas com que é encontrado na natureza. No decorrer de sua história, tem sido encontrado na forma nativa, isto é, em pepitas. Contudo, o ouro ocorre sobretudo na forma de pequenos grãos de metal disseminados em veios de quartzo. Muitas dessas rochas foram erodidas pelo tempo.

O ouro e as rochas decompostas são lavadas e arrastadas para cursos de água, acumulando-se como sedimentos nos leitos dos rios. Nesse caso, os grãos de ouro podem ser separados da areia com auxílio de bateias. O ouro é muito denso, tendo 19,3 gramas por centímetro cúbico, e se sedimenta rapidamente. Com sílica, no entanto, de densidade equivalente a 2,5 gramas por centímetro cúbico, precipita mais lentamente e é desprezado

\footnotetext{
${ }^{114}$ ROMMINGER. Op. cit., p. 285.

${ }^{115}$ GAROFALO FILHO (2004). Op. cit., p. 195.
} 
com a água. Esse procedimento é hoje pouco usado, pois os depósitos de ouro estão quase esgotados. Modernamente, as rochas que contêm traços de ouro são moídas e o ouro é extraído com mercúrio ou cianeto de sódio. A água e a rocha moída são passadas sobre o mercúrio, no qual o ouro se dissolve formando uma amálgama. Após, ele é recuperado destilando-se a amálgama, com o que se separa o mercúrio, que pode ser reaproveitado.

No Brasil esse procedimento tem sido utilizado com água dos rios e areia aurífera. O complexo argentocianeto de sódio é solúvel, separando o ouro do restante da rocha. Dessa solução, o ouro é precipitado, adicionando-se zinco (Zn) em pó. Historicamente, o seu principal uso foi na fabricação de moedas ou seu uso como moeda e quase-moeda, independentemente de ter um emissor oficial.

A quantidade deste presente nas ligas é expressa em quilates. Quando puro tem 24 quilates. As ligas têm geralmente 9 quilates, 18 quilates ou 22 quilates, que contêm respectivamente 9/24, 18/24 e 22/24 de ouro puro. O ouro de 24 quilates também é chamado ouro mil (1.000 partes de ouro por 1.000 partes de metal). Pequenas quantidades de ouro são usadas para fabricar contatos elétricos resistentes à corrosão de aplicação, por exemplo, em computadores. Em galvanoplastia, a douração é utilizada na indústria microeletrônica devido à excelente condutibilidade do ouro, depois da prata e do cobre. Outro uso corrente é em odontologia para fabricação de próteses dentárias ${ }^{116 .}$

\subsubsection{Padrão-Ouro (Gold Standard)}

É um sistema monetário no qual o valor de uma moeda é legalmente definido como uma quantidade fixa de ouro, em termos internacionais, e, em nível interno, o meio circulante sob a forma de moedas de ouro ou notas, papel-moeda, conversíveis a qualquer momento em ouro, de acordo com as taxas de conversão fixadas legalmente. Para que o sistema funcione há duas exigências básicas: a obrigação das autoridades monetárias de converter moeda nacional em ouro de acordo com a taxa de conversão fixada; e a liberdade dos indivíduos de exportar e importar esse metal ${ }^{117}$.

\subsubsection{Padrão Câmbio-Ouro (Gold Exchange Standard)}

Trata-se de uma variante do padrão-ouro, pelo qual um país fixava o valor de sua moeda não diretamente em ouro, mas em outra moeda, como o dólar, por exemplo, cuja

\footnotetext{
${ }^{116}$ GAROFALO FILHO (2004). Op.cit., p. 195/196.

${ }^{117}$ GAROFALO FILHO (2004). Op. cit., p. 199.
} 
cotação, por sua vez, era determinada em termos daquele metal. As autoridades monetárias fixavam a taxa de conversão e mantinham parte ou a totalidade de suas reservas não em ouro, mas em moedas fortes ${ }^{118}$, isto é, moedas vinculadas ao ouro, trocando a moeda nacional pelas reservas de acordo com a taxa de conversão ${ }^{119}$.

Foi extinto nos anos de 1929-1930, em conseqüência da Primeira Guerra Mundial e da desarticulação do mercado internacional na década de 1920-1930.

\subsubsection{Circulação do Ouro nos Países Fundadores do Mercosul}

No Brasil, o ouro pode ser classificado como mercadoria ou ativo financeiro. Em se tratando de mercadoria, sua comercialização externa se processa como a de qualquer outro produto, conforme estabelecido pela $\mathrm{SECEX}^{120}$. Em se tratando de ativo financeiro, o mercado de ouro é regulado pelo Banco Central do Brasil. Nesse caso, este órgão e as instituições autorizadas possuem competência para comprar e vender o metal no mercado internacional.

$\mathrm{Na}$ Argentina, os residentes podem manter ouro no país ou no exterior sob qualquer forma. As instituições financeiras e as casas de câmbio são competentes para comprar ou vender livremente ouro em barra ou em moeda. Não há restrição à importação comercial de ouro, mas, se for destinado para usos industriais, há um imposto de $0,5 \%$. As instituições autorizadas podem exportar ouro para entidades estrangeiras.

No Paraguai, a exportação, assim como a importação, por residentes que não sejam instituições bancárias e por usuários industriais, exceto joalherias, requer prévia autorização do Banco Central do Paraguai. Os pagamentos de importações de ouro para uso industrial devem ser efetuados por bancos comerciais.

\footnotetext{
118 “Designação genérica das moedas mais aceitas nas transações internacionais. Até a Segunda Guerra Mundial, a libra, como moeda forte, era a mais aceita internacionalmente, sendo substituída pelo dólar dos Estados Unidos. De modo geral, qualquer moeda forte, por exemplo, o iene japonês, o Euro, o franco suíço, e outras, pode ser utilizada em pagamentos internacionais, por causa de sua procura e de sua relativa estabilidade." Cf. GAROFALO FILHO (2004). Op. cit., p. 174.

${ }^{119}$ GAROFALO FILHO (2004). Op.cit., 199.

${ }^{120}$ Secretaria de Comércio Exterior. Trata-se de Secretaria integrante da estrutura do MDIC (Ministério do Desenvolvimento, Indústria e Comércio Exterior). Suas funções eram anteriormente exercidas pela CACEX (Carteira de Comércio Exterior), que era, e ainda, é em uma dependência do Banco do Brasil S/A, porém, agora, com outras funções específicas e distintas.
} 
No Uruguai, residentes ou não-residentes podem transacionar livremente com ouro $^{121}$. Para fins industriais, o ouro está sujeito à política governamental de exportação, importação e comércio de mercadorias.

${ }^{121}$ Nesse sentido, é interessante o conteúdo do art. $1^{\circ}$ do Decreto de 11 de agosto de 1952: Artículo $1^{\circ}$.Declárese que las importaciones de oro en monedas barras o lingotes, cualquiera sea su forma de llegada al ppaís, no destinadas a uso industrial, se consideran ingreso de capital y su introducción, comercialización y circulación dentro de la República es completamente libre, sin perjuicio de lo dispuesto en el artículo $9^{\circ}$ del presente decreto. 


\section{CAPÍTULO III}

\section{A MOEDA NO BRASIL}

\section{1 - Na Colonização}

O momento inicial da vida social, política e econômica do Brasil, é fortemente influenciado pelos costumes e valores de seus colonizadores, notadamente dos portugueses e espanhóis. Em um segundo momento, os costumes locais foram sendo construídos sob a influência dos escravos - trazidos da África para servir aos senhores de engenho -, pelos índios que aqui residiam, e, ainda, por gerações decorrentes da mistura de raças entre os nativos e os povos recém chegados.

Conforme ensina FAUSTO ${ }^{122}$, a história do Brasil colonial pode ser dividida em três momentos bem distintos um do outro. Um primeiro período é marcado pela chegada de Pedro Álvares Cabral, e se estende até a instalação dos governos gerais, em 1549; um segundo momento tem início com o advento dos governos gerais e se encerra ao final do século XVIII; e, por sua vez, o terceiro e último período da colonização se inicia no final do século XVIII e se extingue em 1822, com a Proclamação da Independência.

Ao dividir em três fases o período colonial, FAUSTO adota concepções meramente pessoais, distintas, mas complementares, àquelas que seguimos em nossa classificação no presente trabalho. No entanto, acreditamos ser enriquecedora a este estudo a concepção do autor, por destacar a maneira com que o autor visualiza o período de nossa colonização, apresentada de forma didática e centrada nos acontecimentos históricos do período inicial de desenvolvimento do País.

O momento inicial da colonização, compreendido entre a chegada de Cabral e a instalação do governo geral ${ }^{123}$, em 1549 , é caracterizado pelo reconhecimento e posse da

\footnotetext{
${ }^{122}$ FAUSTO, Boris. História do Brasil. 12. edição. São Paulo: Universidade de São Paulo, 2004, p. 41.

123 "Tomé de Souza torna-se governador, assim da povoação de terras da Bahia de Todos os Santos, como das 'outras capitanias e terras da costa'. O Regimento que trazia pode ser mesmo considerado por Serafim Leite um 'documento básico', verdadeira carta magna do Brasil e sua primeira Constituição, tendente à unificação jurisdicional, já com os elementos aptos para uma 'colonização progressiva'. O governo central deveria dar favor e ajuda às mais povoações, ministrar-lhes justiça e prover nas coisas que cumprissem ao serviço de Sua Alteza e aos negócios da Real Fazenda e ao bem das partes, segundo consta textualmente da
} 
terra, e por um escasso comércio. O segundo momento, estendido entre 1549 e o final do século XVIII, foi marcado pela: "montagem da colonização que irá se consolidar ao longo de mais de dois séculos, com marchas e contramarchas".

Já o terceiro período colonial, compreendido entre o fim do século XVIII e a Proclamação da Independência, em 1822, é considerado pelo autor uma referência que indica uma série de transformações, - seja em âmbito mundial, ou nas colônias -, responsável por alavancar a crise do sistema colonial e influenciar os movimentos pela independência nacional ${ }^{124}$.

Em matéria de utilização da moeda, o primeiro período é marcado por muitas trocas de bens e serviços entre os nativos e os povos recém-chegados, especialmente em seu início, no qual os portugueses e espanhóis notaram a existência de pau-brasil, de ouro e de pedras preciosas no território brasileiro. Como os indígenas que aqui habitavam não tinham conhecimento sobre o valor desses bens, eram facilmente ludibriados pelos recém chegados, que lhes entregavam mercadorias de ínfimo valor na permuta, como espelhos, pentes e artigos de vestuário, entre outros utensílios semelhantes, em troca de metais preciosos e pau-brasil.

De todo modo, inexistia um sistema econômico estruturado no Brasil no período inicial da colonização. As moedas em circulação no país eram cunhadas em Portugal, na Espanha, e em outras localidades da Europa. No entanto, predominava a utilização da moeda-mercadoria nas transações entre os povos recém-chegados e os nativos.

Conforme relata $\mathrm{HUGON}^{125}$, a respeito da origem da moeda adotada no período colonial pelo Brasil:

Diversas mercadorias eram utilizadas como moeda nas trocas em regiões de agricultura e de criação; o pó e barras de ouro serviam de moeda em Minas; nas regiões do litoral, do Rio e da Bahia, onde estavam os principais centros comerciais, circulavam várias moedas, cunhadas na colônia, em Portugal, na Espanha e em outras metrópoles européias. As peças trazidas das metrópoles circulavam ao lado das que eram cunhadas em casas de fundição de Minas - desvalorizadas em relação às primeiras. Também circulavam duas outras moedas de prata e de cobre. Cerca de 2/3 desse meio circulante eram de peças monetárias de ouro; o restante

carta régia de 7 de janeiro de 1549.” HOLANDA, Sérgio. A época colonial: do descobrimento à expansão territorial. Rio de Janeiro: Bertrand Brasil, 2000, p. 109.

${ }^{124}$ FAUSTO, Boris (2004), Op. cit., p. 41.

${ }^{125}$ HUGON, Paul. A moeda: introdução à análise e às políticas monetárias e à moeda no Brasil. São Paulo: Pioneiras/Edusp, 1967; São Paulo: Pioneiras/Edusp, 1972, p. 130-144. 
dividia-se entre prata e cobre. Foi isso o que D. João VI encontrou no Brasil à sua chegada, 1808.

Ao longo da História do Brasil, podemos observar que as mudanças na estrutura do poder, assim como no sistema de governo e no desenvolvimento político e social do país (que passou da fase colonial aos governos gerais; da chegada da família real à independência política; do Império à Primeira e Segunda Repúblicas; e do período Democrático e Regime Militar à atual República Presidencialista), estão diretamente ligados, e foram os principais influenciadores das transformações e da evolução do sistema monetário nacional.

\section{2 - Durante os Governos Gerais}

Importante para o estabelecimento de um sistema monetário no Brasil foi a edição das Ordenações Filipinas, que passou a viger, à época, no País e em Portugal. Entrando em vigor em 11 de janeiro de 1603, essas Ordenações só deixaram de operar plenamente no Brasil com o Código Civil de 1916.

JANSEN $^{126}$ destaca algumas das regras do referido conjunto normativo, já que importantes dentro do campo do sistema monetário: do Livro I, Título LXII, § 47, e Título LXXVIII, § 16; do Livro II, Título XXVI, $\S 3^{\circ}$; do Livro IV, Título XXI, Título XXII, Título L; e do Livro V, Título XII. Dentre elas, merecem menção, no nosso entender, as seguintes pela sua relevância.

A norma do $\S 3^{\circ}$ do Título XXVI, do Livro II, impunha o monopólio estatal da emissão da moeda, prerrogativa já anteriormente tutelada em Portugal pelas Ordenações Afonsinas $^{127}$ e Ordenações Manuelinas ${ }^{128}$, salvaguardando para o Estado a "auctoridade para fazer moeda".

Também é digna de nota a norma do Livro IV, Título XXI, que rezava: "Em que moeda se farão os pagamentos do que se compra, ou deve: posto que alguns compradores e vendedores, e outros contratantes se concertem, que se haja de pagar certa moeda de ouro, ou de prata, será o vendedor obrigado a receber qualquer moeda corrente lavrada do nosso cunho, ou dos Reis, que ante nos foram, na valia, que lhe por nos for posta."

\footnotetext{
126 JANSEN, Letácio. A esquizofrenia monetária: Pequena história jurídica do mil réis. Revista Forense, vol. 381, 2005 , p. 87.

${ }^{127}$ No Livro II, Titulo VII, artigo XXIII, combinado com o Livro V, Titulo V, § $7^{\circ}$.

${ }^{128}$ No Livro II, Titulo XV.
} 
Prosseguindo no estudo, por último destacamos a norma do Livro I, Título LXII, § 47, que dizia: "E o preço, que os foreiros hão de pagar dos foros, que houverem per alguma das maneiras atraz declaradas, será declarado nos contratos e será da moeda que correr ao tempo do contracto. E posto que as valias das ditas moedas se mudem, sempre se pagará a respeito da valia da moeda, declarada no contracto."

Sobre essa norma, comparando-a com a antiga disposição do Livro II, Título XXXV, $\S 44$ das Ordenações Manuelinas, a fim de mostrar o progresso que representava no início de sua vigência, JANSEN afirma:

\begin{abstract}
A disposição (...) das Ordenações Manuelinas (...) vinculava a liquidação do débito ao peso e à liga do metal de que se compunha a pega monetária referida no contrato. Já as Ordenações Filipinas, na norma Livro I, Título LXII, § 47, ao vincular a liquidação da dívida não ao peso metal e liga de que se compunha a pega monetária - mas à unidade monetária referida no contrato, positivava o princípio nominalista, e isso, note-se bem, em 1603, data muito próxima àquela em que o mesmo princípio ingressara na ordem jurídica da França (em 1602) e da Inglaterra (em 1604). ${ }^{129}$
\end{abstract}

No entanto, apesar do adiantado da norma, somente em 1688 foi implantado o primeiro sistema monetário no Brasil, ainda que bastante rudimentar. O sistema foi substituído em 1722 pelo bicameralismo, baseado na cunhagem sem limitação das moedas utilizadas, o ouro e a prata. As moedas de cobre, cunhadas em Portugal, na Espanha e em outras metrópoles européias, por deterem menores valores, eram utilizadas para o fracionamento das quantias monetárias ${ }^{130}$.

\title{
3.3 - À Época de D. João VI
}

Com a chegada de D. João VI ao Brasil foi criado o primeiro banco em nosso território, o Banco do Brasil, através do Alvará de 12 de outubro de $1808^{131}$. Dentre suas

\footnotetext{
${ }^{129}$ JANSEN, Letácio. Op. cit., p. 87.

${ }^{130}$ Vide maiores informações em: SOUZA, Carlos Inglez. A anarquia monetária e suas conseqüências. São Paulo: Cia. Monteiro Lobato, 1924.

${ }^{131}$ Criado em 12 de outubro de 1808, pelo Alvará de 12/10, do Príncipe D. João VI, o Banco do Brasil foi o primeiro Banco do País e o quarto Banco emissor de moeda do mundo. Atribui-se a iniciativa de sua criação a D. Rodrigo de Souza Coutinho, que não assinou o alvará por não ser o Ministro da Fazenda. Tinha por finalidades, indicadas no Alvará de criação "em primeiro lugar, conseguir fundos necessários para a manutenção da própria Monarquia; secundàriamente [sic], facilitar o pagamento de soldos, ordenados, juros e pensões, engrandecendo, assim, o crédito público; e, por fim, animar e promover as transações mercantis, erigindo mais uma fonte de riqueza. (...) Em virtude desta terceira finalidade, principiou o primeiro Banco do
} 
funções, figurava a de emissor de notas representativas, com garantia de conversibilidade total em ouro. Praticamente, todo o instrumento monetário circulante era integrado por moedas metálicas.

Havia, ainda, em circulação nesse período, uma espécie de antecessor do papelmoeda, o denominado 'bilhete de permuta', representado por recibos emitidos pela Casa da Moeda $^{132}$, em decorrência do recolhimento de montantes de moedas metálicas. Tais recibos eram emitidos para efeito de liquidação de transações, mediante transferência via endosso. Sua circulação como meio de pagamento foi legalizada, por meio do Alvará de 13 de maio de 1803 expedido pelo governo.

D. João $\mathrm{VI}^{133}$ propôs, desde o início de seu governo, uma série de medidas econômicas liberalizantes, com o intuito de aperfeiçoar as estruturas financeiras e a economia do país ${ }^{134}$. Assim, ordenou a abertura dos portos, a permissão da abertura de

Brasil como um banco de depósitos, depósitos, descontos e emissão, banco misto, portanto. Com a duração prevista de vinte anos, constituía-se em sociedade particular, com um capital de 1200 contos de réis, representado por 1200 ações de um conto de réis e com autorização para aumento de capital. A responsabilidade do acionista era limitada ao montante da ação, o que acarretava a proibição da ação pignoratícia civil ou fiscal, contra qualquer dos acionistas ou membros da diretoria. (...) A administração do nosso primeiro estabelecimento bancário era exercida por uma assembléia de quarenta dos maiores capitalistas portugueses, seus acionistas, uma junta de dez membros, renováveis a metade cada ano, e uma diretoria de quatro membros, também renováveis no mesmo período. A diretoria era representada por quatro membros de Junta encarregando-se cada um dos diretores de uma operação bancária. Só possuía direito de voto deliberativo cada portador de cinco ações ou mais. Como banco comercial, encarregava-se do desconto de letras de câmbio, comissões por cobranças, adiantamentos e hipotecas, depósitos de valores, vencendo juros e venda de produtos monopolizados pela Coroa. Suas operações monetárias constavam de emissão de notas bancárias e letras a vista [sic] ou a prazo fixo, operações cambiais de saque e remessa e operações de compra e venda de ouro e prata. O sistema monetário, que assim se criara, consistia em moeda de papel conversível a vista [sic] em moeda metálica, ouro ou prata, tendo como nota mínima o valor de $30 \$ 000$. Deste modo, evitava-se que as notas circulassem em pequenas transações, limitando-se a pagamentos elevados no comércio atacadista, quase não circulando no comércio varejista, onde as transações, muito pequenas, quase não davam margem ao seu giro" HOLANDA, Sérgio Buarque de (Org.). O Brasil monárquico: o processo de emancipação. Rio de Janeiro: Bertrand Brasil, 2001, p. 109-110.

${ }^{132}$ De acordo com dados oficiais do sítio na internet da Casa do Moeda do Brasil, essa empresa pública foi criada em 08 de março de 1694, pelos governantes portugueses para o fabrico de moedas com o outro proveniente das minerações. A Casa da Moeda hoje tem as funções de: impressão das cédulas do meio circulante nacional; cunhagem de moedas de circulação e de moedas e medalhas comemorativas; e produção de produtos gráficos de segurança, tais como selos fiscais e postais, passaportes, cartões indutivos para telefonia, bilhetes magnetizados para transporte via metrô e ônibus, carteiras de trabalho, selos cartoriais e outros produtos. Sítio oficial da Casa da Moeda do Brasil <http://www.casadamoeda.gov.br>. Acesso em: 22 nov. 2008.

${ }^{133}$ D. João VI veio para o Brasil, juntamente com sua corte, em 1808, pressionado entre Inglaterra e França, que representavam, respectivamente, de um lado o capital que nutria a vida no reino lusitano, e de outro, a força militar rápida e eficiente de Napoleão Bonaparte que ameaçava invadir e conquistar Portugal. Então, para não enfrentar o conquistador francês, D. João VI refugiou-se para terras brasileiras, com auxílio da armada inglesa, tendo chegado à Bahia de Todos os Santos em 24 de janeiro de 1808 e ao Rio de Janeiro em 07 de março de 1808, onde se instalou, permanecendo até o dia 25 de abril de 1821. Para maiores informações, consultar: HOLANDA, Sérgio Buarque de (Org.). O Brasil monárquico: o processo de emancipação. Rio de Janeiro: Bertrand Brasil, 2001, p. 109-110.

${ }^{134}$ SARAIVA, José Hermano. História concisa de Portugal. 20. ed. Portugal: Publicações Europa-Amércia, 1999, p. 273-274. 
indústrias no território nacional, e a livre concessão de franquias comerciais, o que levou à multiplicação das transações comerciais no interior do país e no exterior, e a um aumento do volume de moeda circulante no interior das fronteiras nacionais ${ }^{135}$.

Em que pesem os benefícios econômicos conquistados pelo país durante o governo de D. João VI, os elevados gastos da corte e os investimentos em armamentos, efetuados durante as revoluções na Província do Rio da Prata; em Pernambuco, com a revolução de 1817; e na Bahia, provocaram sérios desajustes no sistema monetário. Em razão desses fatores, o governo passou a autorizar a emissão de moeda destituída de lastro em ouro ${ }^{136}$, o que provocou um descontrole na relação entre a quantidade de moedas em circulação e as reservas nacionais.

Nos anos de 1814 a 1820, os bilhetes em circulação aumentaram de 1.042 mil para 8.070 mil contos de réis, sendo que, em 1920 os depósitos metálicos, ou seja, a reserva do Banco do Brasil era de apenas $1.315 \operatorname{contos}^{137}$.

Assim, não tardou a crise monetária, decorrente da desproporção entre as moedas circulantes, que ultrapassaram em seis vezes o lastro em ouro existente ${ }^{138}$. Com a crise, as jóias da coroa foram oferecidas em garantia. Contudo, o governo suspendeu a convertibilidade das notas representativas em 1821, por ocasião do total desajuste da conversão da moeda em ouro.

\section{4 - Na Independência}

Conforme nos relata FAUSTO, a consolidação da Independência ocorreu em breve espaço de tempo. Contudo, não se fez sem conflitos militares relativamente graves.

\footnotetext{
${ }^{135}$ Dentre os principais diplomas legais elaborados à época, destacam-se: Decreto de 28 de janeiro de 1808 (abertura dos portos); Alvará de 28/5 (de 28 de maio de 1808, abolição da proibição de instalação de fábricas no Brasil e em todos os domínios ultramarinhos); Alvará de 23/8 (Criação da Real Junta do Comércio, Agricultura, Fábricas e Navegação - 23 de agosto de 1808); e Alvará 01/9 (Determinação para circulação de moedas de ouro, prata e cobre e proibição de ouro em pó - 01 de setembro de 1808).

${ }^{136}$ Nos termos do alvará do príncipe regente D. João datado de 12 de outubro de 1808: “(...) Em todos os pagamentos que se fizerem á minha Real Fazenda, serão contemplados e recebidos como dinheiro os bilhetes do dito Banco Publico, pagaveis ao portador ou mostrador à vista; e da mesma fórma se distribuirão pelo Erario Régio nos pagamentos das despezas do Estado (...) 4. Na emissão de letras, ou bilhetes pagaveis ao portador à vista, ou a um certo prazo de tempo, com a necessaria cautela para que jámais estas letras, ou bilhetes deixem de ser pagos no acto da apresentação; sendo a menor quantia por que o Banco poderá emittir uma letra ou bilhete, a de 30\$000.” BRASIL. Leis etc. Colecção das leis do Brazil de 1808. Rio de Janeiro: Imprensa Nacional, 1891, p. 148 e 153.

${ }^{137}$ ANDRADA, Antonio Carlos Ribeiro de. Bancos de emissão no Brasil. Rio de Janeiro: Livraria Leite Ribeiro, 1923, p. 11.

${ }^{138}$ Para maiores detalhes sobre a situação financeira brasileira na época, consultar: FRANCO, Bernardo de Souza. Os bancos do Brasil. (primeira edição de 1848). Brasília: Editora da Universidade de Brasília.
} 
Segundo relatos do autor, os brasileiros favoráveis à independência agregaram forças consideráveis para lutar contra as tropas portuguesas aqui sediadas desde a chegada da família real, em $1808^{139}$.

Já no campo econômico e político, e que pode, também, ter contribuído para acelerar o processo da independência, é de se notar que, em 1821, o balanço das operações do Banco do Brasil revelou seu estado pré-falimentar e um saldo devedor de 6.016 contos de réis. A situação foi agravada quando, ao voltar para Portugal, D. João VI retirou jóias e metais preciosos dos cofres do Banco ${ }^{140}$, levando a uma desvalorização dos bilhetes emitidos pela instituição.

Em conseqüência, a circulação das moedas metálicas diminuiu, pois, além de serem usadas como meio de pagamento nas transações internacionais, as moedas metálicas passaram a valer mais do que os bilhetes do Banco do Brasil.

Sem lastro financeiro, o Banco do Brasil prosseguiu, ao longo dos anos de 1820, a política de emissões subordinadas às exigências impostas pelo financiamento dos gastos públicos.

\section{5 - Durante o Império}

Com a efetiva proclamação da independência do Brasil, em 1822, D. Pedro assumiu o governo brasileiro, e desde o início de seu reinado se propôs a solucionar a crise monetária instalada no país durante o governo de D. João VI, que, em 1821, havia retornado a Portugal, por pressão e exigência das cortes portuguesas.

No que se refere à moeda, a Lei de 20 de outubro de 1823 garantiu a continuação do status de moeda nacional em relação ao mil réis, assim como a manutenção do sistema financeiro anteriormente vigente. Reza o artigo $1^{\circ}$ desta lei, in verbis:

As Ordenações, Leis, Regimentos, Alvarás, Decretos, e Resoluções promulgadas pelos Reis de Portugal, e pelas quaes o Brazil se governava ate o dia 25 de Abril de 1821, em que Sua Magestade Fidelissima, actual Rei de Portugal, e Algarves, se ausentou desta Corte; e todas as que foram promulgadas daquella data em diante pelo Senhor D. Pedro de Alcantara,

\footnotetext{
${ }^{139}$ FAUSTO, Boris (2004), Op. cit., p. 143.

140 "Em 1821, o Banco do Brasil sofreu um duro golpe nos seus cofres, quando da repatriação de D. João VI e de sua imensa comitiva. Com a sua partida, desfalcou o erário e levou todo o depósito metálico existente no banco, deixando-o sem qualquer encaixe." FAVARETTO, Isolde. Releitura do intervencionismo estatal no sistema financeiro nacional. In: Direito \& Justiça, ano XXVII, vol. 31, nº 2, p. 109-153, 2005, p. 122.
} 
como Regente do Brazil, em quanto Reino, e como Imperador Constitucional delle, desde que se erigiu em Império, ficam em inteiro vigor na parte, em que não tiverem sido revogadas, para por ellas se regularem os negocios do interior deste Império, emquanto se não organizar um novo Código, ou não forem especialmente alteradas.

Em 1828, no entanto, já era grande a oposição ao Banco do Brasil, que foi proibido de fazer novas emissões, consideradas uma das principais causas das desvalorizações cambiais. Em meio a um clima de franca acusação aos antigos diretores do Banco do Brasil, o Parlamento decidiu, em 1829, encerrar as atividades da mencionada entidade financeira.

Após o fechamento da instituição, as notas do Banco do Brasil foram trocadas pelas notas inconversíveis do Tesouro Nacional ${ }^{141}$, o qual, naquele momento, passaria a centralizar o poder emissor $^{142}$.

O Banco do Brasil e o Tesouro Nacional haviam perdido a prerrogativa da emissão de moeda, o que provocou sérias dificuldades para saldar as despesas efetuadas pelo reinado.

Assim, para remediar a crise financeira, D. Pedro ordenou a cunhagem de moedas de cobre pela Casa da Moeda, instituindo uma nova modalidade de moeda de valor, juntamente com as notas representativas, ainda em circulação nacional. Entretanto, devido: (i) à flexibilidade das regras de cunhagem; (ii) às exigências de recursos por parte do Tesouro Nacional; e (iii) à facilidade com que a moeda de cobre vinha sendo falsificada, a emissão de tal moeda foi pouco a pouco sendo reduzida, e aquelas ainda em circulação foram convertidas em obrigações do governo, sendo recolhidas e resgatadas posteriormente. Assim, sendo o porto de Salvador o grande centro de entrada e distribuição dessas moedas, o governo, em 1827, determinou o seu recolhimento na província da Bahia, fazendo a troca por cédulas, resgatáveis em 8 ou até 24 meses. A moeda de cobre e as notas representativas, emitidas pelo Banco do Brasil, foram substituídas por papel-moeda, legalmente autorizado, pela primeira vez, e emitido pelo Tesouro Nacional ${ }^{143}$.

\footnotetext{
${ }^{141}$ O Tesouro Público Nacional foi criado pelo Decreto-Lei $\mathrm{n}^{\circ} 22$, de 16 de maio de 1833, substituindo o Erário Régio - Tesouro do Soberano ou do Príncipe. Com este Decreto efetuou-se a separação dos haveres da Nação dos haveres do Soberano e estabeleceu-se, pela primeira vez, a definição clássica do Tesouro Nacional como a união de todos os direitos, rendas e bens da Fazenda Pública.

${ }^{142}$ LISSA, Violo Ídolo. Catálogo do papel - moeda do Brasil 1771- 1986. Brasília: Gráfica Brasiliana Ltda., 1987, p. 14.

${ }^{143}$ LOPES, João do Carmo; ROSSETTI, José Paschoal. Op. cit., p. 38.
} 
Em 1829, o Banco do Brasil passou por liquidação ${ }^{144}$, e como conseqüência, promoveu a substituição das notas representativas de sua emissão por papel-moeda, emitido, de início, pelo Tesouro Nacional, e destituído de conversibilidade em ouro. Antes, porém, da liquidação definitiva se operar, a Regência Permanente, em nome do Imperador, editou a Lei $\mathrm{n}^{\mathrm{o}} 59$, de 8 de outubro de 1833, que estabeleceu a criação de um banco de circulação e de depósitos, que também se denominaria Banco do Brasil, com sede no Rio de Janeiro, fixando um prazo de três anos para ser organizado, o que nunca chegou a ser efetivado $^{145}$.

Em 1846, o sistema monetário brasileiro restaurou o padrão-ouro ${ }^{146}$, voltando a ser o padrão-moeda, portanto, conversível em ouro ${ }^{147}$, e, em 1849 , com a implementação no País do sistema monometálico, a moeda de prata teve sua emissão reduzida, passando à condição de moeda auxiliar. Como conseqüência, o Brasil restabeleceu sua tranqüilidade monetária interna, e pôde desenvolver seu comércio exterior, beneficiando-se do progresso técnico proveniente da Revolução Industrial, implementada na Inglaterra. Pôde ainda fortalecer sua estrutura econômica, em razão de uma balança comercial favorável a partir de 1854 e da possibilidade de acumular ouro como reserva.

Um segundo Banco do Brasil foi instituído em 1851, por meio da fusão do Banco Comercial do Rio de Janeiro e do Banco Mauá ${ }^{148}$, e o monopólio da emissão de moedas lhe foi outorgado pelo governo. O capital do Banco, de 10.000 contos de réis, era considerado grande para os padrões da época e foi dividido em 20 mil ações, de $500 \$$ réis cada uma ${ }^{149}$. O novo banco fixou como limite de emissão da moeda o montante equivalente ao dobro do capital disponível naquele momento.

O governo, através do Decreto $n^{\circ} 3.306$ de 1864, revogou o dispositivo legal que facultava aos bancos a atividade emissora, medida que atingiu até o próprio Banco do Brasil que, a partir de 1866, deixou de ser banco emissor para ser banco de depósitos, descontos e empréstimos sobre hipotecas ${ }^{150}$. A titularidade do direito de emissão da moeda

\footnotetext{
${ }^{144}$ Nos termos do art. $1^{\circ}$ da Lei de 23 de setembro de 1829: "O Banco do Brazil, creado pela Lei de 12 de Outubro de 1808, continua até o dia 11 de Dezembro do corrente anno, em que termina o prazo, que lhe concedêra a dita lei, começando porém desde já a sua liquidação.” Disponível em: <www.camara.gov.br>. Acesso em: 7 dez. 2008.

${ }^{145}$ AZEVEDO, Thales de.; LINS, Edilberto Quintela Vieira. História do banco da Bahia - 1858-1958. Rio de Janeiro: José Olympio, 1969, p.31.

${ }^{146}$ Em 1846, a lei 401, de 11 de setembro de 1846 (regulada pelo Decreto 487, de 28 de novembro de 1846) inseriu o país nas regras do padrão-ouro ao estabelecer a paridade fixa de 27 pences por mil réis.

${ }^{147}$ SANT'ANA, José Antonio (1997). Op. cit., p. 16.

${ }^{148} \mathrm{O}$ Decreto $\mathrm{n}^{\circ} 801$ de 2 de Julho de 1851 autoriza a organização do Banco e aprova o estatuto.

${ }^{149}$ CALDEIRA, Jorge. Mauá. Empresário do império. São Paulo: Companhia das Letras, 1995, p. 226.

${ }^{150} \mathrm{O}$ novo perfil do Banco do Brasil foi definido através do Decreto $\mathrm{n}^{\circ} 3.717$, de 13.10.1866, documento
} 
retornou ao Tesouro Nacional, a partir de 1866. Em cinco anos, o Tesouro lançou no meio circulante, três vezes mais do que a quantidade de papéis existentes no mercado, sem o correspondente aumento das transações no período. Com a entrada de tais papéis em circulação houve elevação de seu valor, causando escassez no meio circulante, fazendo-se necessárias novas emissões para enfrentar a demanda ${ }^{151}$.

Com o fim da guerra do Paraguai, em 1870, a emissão de moeda foi reduzida e as notas em circulação adquiriram lastro, devido à reserva proporcional de ouro acumulado pelo país. Em 1888, o governo restabeleceu a conversibilidade plena da moeda em ouro. ${ }^{152}$

\section{6 - Na Primeira República}

Com a passagem do Império para a República, os vários grupos que disputavam o poder político no país divergiam sobre a linha de conduta político-econômica a ser adotada no Brasil. No plano político, os representantes da classe dominante nas principais províncias - São Paulo, Minas Gerais e Rio Grande do Sul - sustentavam a idéia de construção de uma República Federativa, capaz de assegurar uma ampla autonomia às unidades regionais. Por outro lado, Minas Gerais defendia a instauração de ideais liberais no Brasil. Os representantes políticos do Rio Grande do Sul eram positivistas.

Conquanto a discordância de opiniões partidárias, a idéia de sustentação política da República se pautou na representação dos cidadãos pelo Congresso Nacional e por um Presidente eleito pelo povo ${ }^{153}$.

$\mathrm{Na}$ esfera econômica, as controvérsias entre 'papelistas' e 'metalistas' influenciaram largamente as decisões governamentais com relação às medidas econômicas adotadas no país. O Brasil passou por um período bastante conturbado no campo econômico, como decorrência dos movimentos inflacionários e da busca pela estruturação de um sistema monetário sob ideologias e forças econômicas divergentes.

No início do primeiro período republicano, o Visconde de Ouro Preto ${ }^{154}$, então ministro, propôs uma reestruturação do sistema monetário, tomando por base o resgate do

\footnotetext{
onde foi aprovado o acordo realizado entre essa instituição e o governo.

${ }^{151}$ MAUÁ, Visconde de. Autobiografia. 3. ed. Rio de Janeiro: Topbooks, 1998, p. 306.

${ }^{152}$ Nos termos da Lei ${ }^{\circ} 3.403$, de 24 de novembro de 1888.

${ }^{153}$ Cf. FAUSTO, Boris (2004). Op. cit., p. 245.

154 "O estadista mineiro que fora talvez o mais ativo dos auxiliares de Zacarias de Góis em seu terceiro ministério, tinha todas as virtudes que se podem requerer de um administrador, mas do ponto de vista político tinha qualidades negativas. $\mathrm{O}$ defeito maior estava na sua destemida intransigência. Uma vez traçado um
} 
papel-moeda e a conversibilidade em ouro do papel-moeda circulante ${ }^{155}$. Lançou ainda, a idéia de criação de um Banco Central, responsável pelo controle da emissão de moeda e fiscalização dos demais bancos comerciais em funcionamento. No entanto, não logrou êxito em suas tentativas de implantação das novas medidas.

Durante o período, em especial no ano de 1890, foram criados no Brasil novos bancos de emissão de moeda. No entanto, o que à primeira vista parecia a promoção de um verdadeiro ajuste e estruturação na economia monetária, acabou por revelar-se em uma continuidade de atos de desajustes, a começar pelo descontrole nas emissões de moeda, e ampliação da concessão de créditos às indústrias, responsáveis pelo aumento nos índices de inflação ${ }^{156}$.

Nessa época, ocorreu o chamado 'encilhamento' ${ }^{157}$, em decorrência da elevada especulação na bolsa de valores, e do descrédito da população com relação à moeda circulante. Tendo em vista a crise provocada pelo alto índice de inflação, evasão do ouro, e aumento da especulação na bolsa de valores, como conseqüência do 'encilhamento', o Banco do Brasil faliu, assim como os demais bancos comerciais operantes no País.

No período imediatamente anterior à eclosão da I Guerra Mundial, em meio à crise econômica nacional gerada pela inflação e pela desvalorização do câmbio, o país passou por uma reforma generalizada no sistema monetário, tendo sido, por conseqüência, incineradas as cédulas monetárias em circulação, assim como reduzida a emissão de moeda e valorizada a taxa de câmbio a partir de contra-reforma implementada em 1898 e influenciada por Joaquim Murtinho ${ }^{158}$.

plano de ação, não admitia estorvo que o detivesse, nem risco que o alarmasse. Titular da Fazenda do ministério de 5 de janeiro, reclamou, contra tudo e contra todos, a cobrança do imposto do vintém, e provocou o motim do vintém, que deu por terra com o gabinete." HOLANDA, Sérgio Buarque de (Org.). O Brasil monárquico: do império à república. Rio de Janeiro: Bertrand Brasil, 1997, p. 355.

${ }^{155}$ Em 6 de julho de 1889, o Visconde de Ouro Preto fez aprovar uma nova regulamentação para a Lei $3.403 / 1888$, o Decreto 10.262/1889, estabelecendo a autorização para bancos privados emitirem papel moeda conversível em ouro à paridade de 1846 na razão do triplo do capital subscrito em moeda metálica.

156 “(...) O governo recebeu várias propostas de criação de grandes bancos. Em julho, Ouro Preto fez expedir novo regulamento só para os bancos de fundo metálico (decreto $\mathrm{n}^{\mathrm{o}} 10.262$, de 6 de julho de 1889). O grande banco emissor planejado foi o Banco Nacional do Brasil, com capital de 900 mil contos. Outros bancos, como o Banco de São Paulo e o Banco do Comércio, celebraram contratos para resgate de papel-moeda. Esses bancos emissores, com vários outros, foram os desencadeadores de uma fase de especulação desenfreada no mercado acionário. O decreto de 6 de julho continuou em vigor até o início de 1890, várias instituições foram autorizadas a funcionar no final de 1889." MACHADO, Maria. Rui Barbosa: pensamento e ação. Rio de Janeiro: Fundação Rui Barbosa, 2002, p. 83.

157 "Movimento incomum de especulação na Bolsa que ocorreu durante o começo da República, de que resultaram transtornos econômicos de toda ordem”. AURÉLIO. Dicionário da Língua Portuguesa. Disponível em: $<$ http://houaiss.uol.com.br/busca.jhtm?verbete=encilhamento\&stype=k $>$. Acesso em: 2 maio 2008.

${ }^{158}$ Na vida pública, foi senador da República por três mandatos (1890 a 1896, 1903 a 1906, e 1907 a 1911$)$. 
Durante a Primeira República, ainda permanecia o entendimento de que o padrãoouro era indispensável para a inserção do Brasil, rumo ao crescimento, na economia internacional. $\mathrm{Na}$ tentativa de implantar esse regime monetário, primeiro surgiu o Decreto $\mathrm{n}^{\circ} 1.575$, de 6 de dezembro de 1906, que instituiu a Caixa de Conversão e, após, houve tentativa no mesmo sentido através da criação da Caixa de Estabilização, disciplinada pelos Decretos $\mathrm{n}^{\text {os }} 5.108$, de 18 de dezembro de 1926, e 17.618, de 5 de Janeiro de 1927.

Visualizando-se o primeiro desses decretos, é possível averiguar "a sua vigorosa obediência às regras do padrão-ouro" $" 159$ :

\begin{abstract}
Art. $1^{\circ}$ É instituída uma Caixa de Conversão especialmente destinada a receber moedas de ouro de curso legal e as que constam do art. $5^{\circ}$ desta lei, entregando em troca bilhetes ao portador, representativas de valor igual ao das moedas de ouro recebidas, fixado este valor em 15 dinheiros esterlinos por mil reis.

$\S 1^{\circ}$ Os bilhetes emitidos pela Caixa de Conversão terão curso legal, possuindo assim efeito liberatório para todos os contratos e pagamentos em geral, excetuados os referidos no art. $2^{\circ}$ desta lei, e serão resgatados e pagos, a vista, a quem os entregar, para serem trocados por moeda de ouro na mesma Caixa.

$\S 2^{\circ} \mathrm{O}$ ouro que a Caixa de Conversão receber em troca dos bilhetes que emitir será conservado em depósito e não poderá ser destinado, em caso algum, nem por ordem alguma, a outro fim que não seja o de converter ao tipo de câmbio fixado os bilhetes emitidos, sob a responsabilidade pessoal dos membros da Caixa de Conversão e com a garantia do Tesouro Nacional.

$\S 3^{\circ}$ Os bilhetes que forem apresentados a troco e resgatados não voltarão a circulação e serão incinerados ou, por outra forma, inutilizados.

$\S 4^{\circ}$ Enquanto não forem impressos bilhetes especiaes para serem emitidos pela Caixa de Conversão, poderão ser utilizadas, para este fim, notas do Tesouro não usadas, que serão devidamente assinadas e conterão as necessárias declarações.
\end{abstract}

Sobre o destino da Caixa de Conversão, JANSEN esclarece:

A Caixa de Conversão foi extinta cerca de oito anos depois de sua constituição, por força da Lei $\mathrm{n}^{\circ} 2.862$, de 15 de agosto de 1914, recomeçando, a partir dai, a emissão de moeda inconversível do Tesouro. A Caixa foi sendo gradualmente liquidada e, apesar do reinício intermitente dos pagamentos, fechou em 1920, quando o restante de suas reservas foi transferido para o Tesouro ${ }^{160}$.

Estadista, ganhou fama por restaurar as finanças republicanas. Seus cargos públicos incluem: ministro da Viação, Indústria e Comércio, ministro da Fazenda, professor catedrático da Escola Politécnica e vicepresidente do Senado. (GUIMARÃES ROCHA, Recanto das Letras. Disponível em: $<$ http://recantodasletras.uol.com.br/biografias/130166>. Acesso em: 10 jan. 2009).

159 JANSEN, Letácio. Op. cit., p. 100.

${ }^{160}$ Ibidem. 
Com o advento da I Guerra, novamente a economia nacional se desestruturou, ensejando a redução das reservas nacionais em ouro, déficit comercial sobre a economia, aumento em $88 \%$ das emissões de papel-moeda pelo Tesouro, e a suspensão pelo governo da conversibilidade da moeda em ouro ${ }^{161}$.

No prosseguimento, em 13 de novembro de 1920, com a promulgação no Brasil da Lei $\mathrm{n}^{\circ} 4.182$, complementada a seguir pela Lei $\mathrm{n}^{\circ} 4.230$, foi instituída a Carteira de Emissão e Redesconto do Banco do Brasil ${ }^{162}$, sob a coordenação do diretor do Banco, nomeado pelo Presidente da República do Brasil. A Carteira de Emissão e Redesconto teria a atribuição de fomentar os trabalhos de criação futura do Banco Central do Brasil.

Nesse contexto, o Banco do Brasil acumulou as funções de banco comercial e de órgão financeiro do país, passando a ser considerado uma espécie de antecessor do Banco Central, o banco dos bancos ${ }^{163}$. Atuou diretamente no redesconto dos papéis dos demais bancos nacionais, na manipulação das taxas de desconto, e na atração de investimentos e depósitos.

O diretor da Carteira de Emissão e Redesconto detinha a atribuição de administrar a Caixa de Mobilização Bancária, sob a supervisão do Presidente do Banco do Brasil, do Ministro da Fazenda, e de um Conselho composto por três membros nomeados pelo Ministro da Fazenda.

A Carteira de Emissão e Redesconto foi extinta em 1923, por meio do Decreto ${ }^{\circ}$ 4.635-A, tendo sido substituída pela Carteira de Emissão no Banco do Brasil, o que conferiu a essa instituição a função e o monopólio de órgão emissor de moeda no País ${ }^{164}$. Dessa forma, em 1923 o país passou por nova reforma monetária e as emissões de moeda

\footnotetext{
${ }^{161}$ LOPES, João do Carmo; ROSSETTI, José Paschoal. Op. cit., p. 40.

162 Nos termos do caput do art. $9^{\circ}$ da Lei 4182/1920, "Fica instituida no Banco do Brasil, sob a superintendencia do presidente desse instituto e a cargo de um director de nomeação do Presidente da Republica, uma Carteira de Emissão e Redesconto, com caixa e contabilidade proprias, emquanto não fôr creado um banco especial para esses fins. O limite de operações dessa carteira será de cem mil contos de réis, e não poderá ser excedido sinão, em caso excepcional, por acto do Presidente da Republica, ficando o Banco sujeito, pela emissão que exceder áquelle limite, á taxa que o Governo determinar."

${ }_{163}$ As funções de banco dos bancos e de prestamista, na época, eram exercidas em conjunto pelo Banco do Brasil, Caixa de Mobilização Bancária e pela Superintendência da Moeda e do Crédito (SUMOC).

164 "Em dezembro de 1922, logo após a posse do novo Governo de Artur Bernardes (15-11-1922 a 15-111926), o Deputado Cincinato Braga apresentou uma lei ao Congresso, propondo a transformação do Banco do Brasil em Banco Central, que foi aprovado logo em seguida (Decreto 4.635-A, de 8-1-1923). Com essa medida, haveria a cessação do funcionamento da Carteira de Redesconto20, em 24-4-1923. Sem deixar de ser o maior banco comercial do país, assumia agora as funções de banco central, dotado do monopólio de emissão de papel-moeda." FIGUEIREDO FILHO, João. Políticas Monetária, Cambial e Bancária no Brasil sob a gestão do Conselho da Sumoc de 1945 a 1955. Dissertação de Mestrado em Economia. Niterói: Universidade Federal Fluminense, 2005, p. 28.
} 
voltaram a ser efetuadas pelo Banco do Brasil, assim como a conversão da moeda em ouro. O Banco do Brasil, mais uma vez autorizado a emitir papel-moeda, colocou em circulação (1923-1926) notas próprias impressas nos Estados Unidos, com valores entre 1.000 réis e um conto de réis ${ }^{165}$. Entretanto, devido aos excessos de concessões de crédito, o Brasil passou por um período de grande inflação e a Carteira de Emissão novamente extinguiu-se.

É criada, então, pelos Decretos n ${ }^{\text {os }} 5.108$, de 18 de dezembro de 1926, e 17.618, de 5 de Janeiro de 1927, como já exposto anteriormente, a Caixa de Estabilização ${ }^{166}$, no intuito de manter o lastro ouro da moeda circulante. No entanto, mesmo com a relevância de sua função, a instituição não teve vida longa no país, devido, justamente, ao novo período de instabilidade instaurado na economia brasileira, como reflexo da crise do café, em 1929, que afetou diretamente a balança comercial nacional, tornando-a deficitária com a queda mundial dos preços do café ${ }^{167}$.

Com a crise, mais uma vez o sistema de manutenção do lastro em ouro e de conversibilidade da moeda foi abalado.

\section{7 - Na República Nova}

Em meio à revolução política dos anos 30, caracterizada pela disputa pelo poder entre Minas Gerais (representante dos interesses ruralistas e oligárquicos) e o Rio Grande do Sul (defensor do liberalismo político e econômico), assume o poder Getúlio Vargas, como Presidente da República, iniciando-se assim uma nova era da história do Brasil, a República Nova, que se estende entre os anos de 1930 e 1945.

Conforme dados históricos, ascenderam ao poder político, na condição de líderes e representantes do povo, militares, técnicos diplomados, jovens políticos, e posteriormente, os industriais. Desde o início do novo governo, as decisões econômicofinanceiras e de natureza política foram centralizadas nas mãos do Presidente, sendo reduzido, de certa forma, o poder oligárquico exercido através do Estado. Isso, no entanto, segundo BORIS FAUSTO, não significou o desaparecimento da oligarquia do poder, nem

\footnotetext{
${ }^{165}$ COSTA NETO, Yttrio Corrêa. Bancos oficiais no Brasil: origem e aspectos de seu desenvolvimento. Brasília: Banco Central do Brasil, 2004. p.45.

${ }^{166}$ Criada pelo Decreto $\mathrm{n}^{\circ} 5.108$, de 1926 , com o fito de promover a reforma do sistema monetário, através da adoção do "Cruzeiro Ouro". Deveria efetuar a troca das notas em ouro e deste em notas.

167 Segundo relatam os pesquisadores Lopes e Rossetti a respeito do processo de liquidação da Caixa de Estabilização: “... as reservas em ouro e em divisas da Caixa de Estabilização reduziram-se de 37\% (1926) para menos de 0,5\% (1931) tendo sido absorvidas pelos Países credores ou com superávit nas transações bilaterais.” LOPES, João do Carmo; ROSSETTI, José Paschoal. Op. cit., p. 41.
} 
uma brusca modificação no padrão das relações sociopolíticas, baseado na 'troca de favores $^{168}$.

Segundo o autor, um novo Estado nasceu após 1930, predominantemente distinto do Estado oligárquico em razão da centralização do poder, e da conquista de uma maior autonomia da esfera pública. O novo Estado adotou posturas distintas do anterior governo, passando, na esfera econômica, a fomentar uma crescente industrialização do País; na esfera social, passou a assegurar uma ampla proteção aos trabalhadores urbanos, incorporando-os, inclusive, a uma aliança de classes instituída pelo governo com o fim de lhes garantir direitos trabalhistas e sociais ${ }^{169}$; e, na esfera militar, o governo atribuiu papel central às Forças Armadas, sobretudo ao exército, com o intuito de possibilitar a manutenção da ordem e da segurança internas ${ }^{170}$.

\footnotetext{
${ }^{168}$ FAUSTO, Boris (2004). Op. cit., p. 327.
}

${ }^{169}$ Nesse sentido, é interessante mencionar que a Constituição de 1934 reconheceu a maioria dos direitos sociais mais difundidos, principalmente no tocante ao trabalho, entre eles: a isonomia salarial, o salário mínimo, a jornada de trabalho de 8 horas; a proibição do trabalho de menores, o repouso semanal, as férias remuneradas, a indenização por dispensa sem justa causa, a assistência médica ao trabalhador e à gestante, bem como reconheceu a existência dos sindicatos e associações profissionais, estabeleceu ainda a submissão do direito de propriedade ao interesse social ou coletivo, entre outras medidas. Ver, a título exemplificativo, o art. 121 da Constituição de 1934: "Art 121 - A lei promoverá o amparo da produção e estabelecerá as condições do trabalho, na cidade e nos campos, tendo em vista a proteção social do trabalhador e os interesses econômicos do país. $\S 1^{\circ}$ - A legislação do trabalho observará os seguintes preceitos, além de outros que colimem melhorar as condições do trabalhador: a) proibição de diferença de salário para um mesmo trabalho, por motivo de idade, sexo, nacionalidade ou estado civil; b) salário mínimo, capaz de satisfazer, conforme as condições de cada região, às necessidades normais do trabalhador; c) trabalho diário não excedente de oito horas, reduzíveis, mas só prorrogáveis nos casos previstos em lei; d) proibição de trabalho a menores de 14 anos; de trabalho noturno a menores de 16 e em indústrias insalubres, a menores de 18 anos e a mulheres; e) repouso hebdomadário, de preferência aos domingos; f) férias anuais remuneradas; g) indenização ao trabalhador dispensado sem justa causa; h) assistência médica e sanitária ao trabalhador e à gestante, assegurando a esta descanso antes e depois do parto, sem prejuízo do salário e do emprego, e instituição de previdência, mediante contribuição igual da União, do empregador e do empregado, a favor da velhice, da invalidez, da maternidade e nos casos de acidentes de trabalho ou de morte; i) regulamentação do exercício de todas as profissões; j) reconhecimento das convenções coletivas, de trabalho. $\S 2^{\circ}$ - Para o efeito deste artigo, não há distinção entre o trabalho manual e o trabalho intelectual ou técnico, nem entre os profissionais respectivos. $\S 3^{\circ}$ - Os serviços de amparo à maternidade e à infância, os referentes ao lar e ao trabalho feminino, assim como a fiscalização e a orientação respectivas, serão incumbidos de preferência a mulheres habilitadas. $\S 4^{\circ}-\mathrm{O}$ trabalho agrícola será objeto de regulamentação especial, em que se atenderá, quanto possível, ao disposto neste artigo. Procurar-se-á fixar o homem no campo, cuidar da sua educação rural, e assegurar ao trabalhador nacional a preferência na colonização e aproveitamento das terras públicas. $\S 5^{\circ}$ - A União promoverá, em cooperação com os Estados, a organização de colônias agrícolas, para onde serão encaminhados os habitantes de zonas empobrecidas, que o desejarem, e os sem trabalho. $\S 6^{\circ}-\mathrm{A}$ entrada de imigrantes no território nacional sofrerá as restrições necessárias à garantia da integração étnica e capacidade física e civil do imigrante, não podendo, porém, a corrente imigratória de cada país exceder, anualmente, o limite de dois por cento sobre o número total dos respectivos nacionais fixados no Brasil durante os últimos cinqüenta anos. $\S 7^{\circ}$ - É vedada a concentração de imigrantes em qualquer ponto do território da União, devendo a lei regular a seleção, localização e assimilação do alienígena. $\S 8^{\circ}$ - Nos acidentes do trabalho em obras públicas da União, dos Estados e dos Municípios, a indenização será feita pela folha de pagamento, dentro de quinze dias depois da sentença, da qual não se admitirá recurso ex officio."

${ }^{170}$ FAUSTO, Boris (2004). Op. cit., p. 327. Conforme pondera o estudioso do tema: “(...) o Estado getulista promoveu o capitalismo nacional, tendo dois suportes: no aparelho do Estado, as Forças Armadas; na 
Segundo JANSEN, “a concretização dos ideais da Revolução de 1930, chefiada por Vargas, exigiu duras medidas de caráter monetário, a primeira das quais, e mais importante, foi a decretação do curso forçado do mil réis-papel, pelo Decreto $\mathrm{n}^{\circ} 23.501$, de 1933" ${ }^{\prime 171}$. Acrescenta ainda que:

Além de abolir a cláusula-ouro, o governo Vargas, através do Decreto ${ }^{\circ}$ 22.626, de 7 de abril de 1933, alterou o regime anterior dos juros, que fora estabelecido pela Lei de 24 de outubro de 1832, impondo limitações de caráter geral às suas taxas, que só foram revogadas em definitivo com a edição do novo Código Civil brasileiro instituído pela Lei $\mathrm{n}^{\mathrm{o}} 10.406$, de 10 de Janeiro de $2002^{172}$.

Durante a II Guerra Mundial, compreendida entre 1939 e 1945, o país passou por uma nova reforma monetária, tendo sido substituída a unidade monetária 'mil réis' pelo 'cruzeiro' ${ }^{173}$ através do Decreto-Lei ${ }^{\circ} 4.791$, de 5 de outubro de 1942 . O artigo 11 do mencionado decreto dispunha que "a partir de $1^{\circ}$ de novembro de 1942, todos os atos e fatos relativos a dinheiro farão referência à nova moeda". Assim, depois de cerca de cento e vinte anos de vigência, ficava revogado, entre nós, o mil réis.

Em regra, apenas o percentual de 25\% das emissões da nova moeda deveria estar lastreado em ouro e em divisas. Mas na prática isso não foi observado, o que culminou na autorização governamental, em 1945, da livre emissão do cruzeiro sem lastro, pelo Tesouro. A conseqüência, sem dúvida, restou desastrosa, pois todo o montante de moeda em circulação se encontrava destituída de lastro e de conversibilidade em moeda estrangeira $^{174}$.

\section{8 - No Período Democrático}

Em 2 de fevereiro de 1945, por meio do Decreto-lei $\mathrm{n}^{\mathrm{o}}$ 7.293, criou-se a Superintendência da Moeda e do Crédito (SUMOC), com a função de controlar o fluxo dos

\footnotetext{
sociedade, uma aliança entre a burguesia industrial e setores da classe trabalhadora urbana." Para finalizar sua análise, pontua: "Foi desse modo, e não porque tivesse atuado na Revolução de 1930, que a burguesia industrial foi promovida, passando a ter vez e força no interior do governo. O projeto de industrialização, com exceção de nomes como o de Roberto Simonsen, foi aliás muito mais dos quadros técnicos governamentais do que dos empresários".

${ }^{171}$ JANSEN, Letácio. Op. cit., p. 101.

172 Ibidem, p. 102.

173 Decreto-lei $\mathrm{n}^{\text {o }}$ 4.791, de 05.10.1942 (D.O.U. de 06.10.42), instituiu o CRUZEIRO como unidade monetária brasileira, com equivalência a mil réis. Foi criado o centavo, correspondente à centésima parte do cruzeiro.

${ }^{174}$ SANT'ANA, José Antonio (1997). Op. cit., p. 17.
} 
meios de pagamentos e implementar a política monetária. A SUMOC, na realidade, atuou como uma espécie de Banco Central provisório, destituída, contudo, da independência e autonomia necessárias a um Banco Central.

O Tesouro Nacional conservou a sua função de emissor da moeda, o cruzeiro, ainda que desatrelado do lastro em ouro. As atribuições do Banco do Brasil também foram mantidas, continuando a atuar como agente financeiro do Tesouro Nacional, e como autoridade monetária. Assim, para fins de emissão de moeda, apenas se fazia necessária uma requisição da Superintendência da Moeda e do Crédito (SUMOC) à Carteira de Redesconto, baseada em ordem do Presidente do Banco do Brasil.

Por exercer funções similares às de um Banco Central, sob a supervisão de outros órgãos e mecanismos governamentais, como o Banco do Brasil (banco com atuação fundamentalmente comercial), e o Tesouro Nacional, e não exercer suas funções com autonomia, a SUMOC era alvo de constantes disputas políticas e pressões partidárias. Nesse sentido, com o tempo o governo chegou à conclusão sobre a necessidade de serem preservados princípios básicos para a sustentabilidade, eficiência e autonomia do sistema monetário $^{175}$.

Assim, com a instauração do Banco Central do Brasil ${ }^{176}$, em $1964^{177}$, em substituição à SUMOC, buscou-se garantir sua independência, especialização e autonomia, para que pudesse adotar e manter uma política monetária sem as pressões existentes na esfera privada dos bancos comerciais.

Em apoio à idéia, discorrendo sobre a autonomia do Banco Central e a sua fundamentação, escreve VERÇOSA:

\footnotetext{
${ }^{175}$ Estudo desenvolvido por Geraldo de Camargo Vidigal sobre a necessidade da criação de um Banco Central autônomo e independente no Brasil, aponta em suas conclusões: "A grande extensão territorial do país e a coexistência, em seu seio, de regiões e de setores de atividade em estágios de desenvolvimento os mais diversos, impõem estejam o Conselho Monetário e o Banco Central armados de organização, poderes e instrumentos hábeis para que possam traçar política, editar normas e adotar medidas compatíveis com a realidade regional e setorial". Sustenta ainda o autor, à época, que, a composição do Conselho Monetário e do corpo diretor do Banco Central deveriam espelhar as opções econômico-filosóficas da nação, de forma a manter a dinâmica seguida pelas instituições, fundadas, de um lado, na iniciativa privada, e, de outro, no condicionamento ao interesse social, devendo, assim, continuar representado eqüitativamente os setores público e privado em ambos os órgãos encarregados da manutenção da política monetária. VIDIGAL, Geraldo de Camargo (1964). Op. cit., p. 68.

176 "No Brasil, talvez a característica mais marcante da história do Banco Central tenha sido a forte e permanente resistência à sua criação. Essa história só encontra paralelo na história do Banco Central dos Estados Unidos da América. A diferença reside no fato de que, enquanto o Federal Reserve americano foi criado após a grande crise bancária de 1907, o Brasil foi um dos últimos países do mundo a criar seu Banco Central, o qual ainda teve que ser criado por etapas para que pudessem ser vencidos os interesses contrários à sua criação." CORAZZA, Gentil. O banco central do Brasil: evolução histórica e institucional. São Leopoldo: Revista Perspectiva Econômica. vol. 2, no 1, jan-jun 2006, p. 2

${ }^{177}$ Através da Lei 4.595, de 31 de dezembro de 1964.
} 
Diante de um banco central autônomo, os governos perdem espaço para a execução de políticas meramente eleitorais ou desenvolvimentistas deficitárias, aumentando o cuidado com as contas públicas, uma vez que não poderão ser socorridos pelo banco emissor, dotado de monopólio efetivo nessa área ${ }^{178}$.

\section{9 - No Regime Militar}

Durante o período em que se instaurou o regime militar no Brasil, entre os anos de 1964 e 1985, além da implantação no país de um parque industrial de base, capaz de proporcionar crescimento econômico e gerar um vasto número de empregos à população, a esfera econômica e financeira ainda contou com a criação do Banco Central do Brasil (BACEN), em 1964, conforme já referido.

Ainda que fosse responsável pela emissão de papel-moeda, o Banco Central ainda não exercia esta função com autonomia, como se pretendia, pois dividia o controle das emissões com o Tesouro Nacional. Durante este período, as emissões permaneceram subordinadas às exigências de financiamento dos déficits públicos, controlados pelo Banco do Brasil, ou seja, o Banco do Brasil também se manteve co-responsável pela emissão de moeda.

Ao analisar as linhas ideológicas dos governos socialista, capitalista democrático e do governo militar, JARBAS PASSARINHO expõe o que considera os maiores benefícios implantados no Brasil, nas áreas econômica e social, durante a vigência do regime militar:

\footnotetext{
A modernização constou ora das reformas econômicas, ora das reformas sociais. As primeiras abrangeram todo o sistema fiscal e financeiro, visando à modernização capitalista ("a operacionalização da economia de mercado e a criação do Banco Central, o Estatuto da Terra, a reforma do sistema habitacional-BNH e o Fundo de Garantia do Tempo de Serviço, o FGTS") ${ }^{179}$.
}

\footnotetext{
${ }^{178}$ VERÇOSA, Haroldo Malheiros Duclerc. Op. cit., p. 87.

${ }^{179}$ PASSARINHO, Jarbas. Governos e choques ideológicos. O Estado de São Paulo, São Paulo, terça- feira, 8 de janeiro de 2008, Espaço Aberto, p. A2.
} 


\subsection{0 - No Regime Presidencialista}

Após um longo período de regime militar, o governo convocou eleições diretas para Presidente do Brasil, logrando-se como conseqüência a passagem do regime militar à tão almejada democracia presidencialista, em 1985. O interesse político da transição se concentrava em duas questões centrais: na revogação das leis advindas do regime militar, que expressamente limitavam as liberdades democráticas dos cidadãos; e na elaboração de uma nova Constituição, com clara proteção aos direitos sociais e à participação popular nas decisões político-econômicas.

Com relação à política monetária, embora concentrasse em si a tarefa de emissão de papel-moeda e de moeda-metálica, o Banco Central permanecia atrelado ao Banco do Brasil e ao Tesouro Nacional num processo que envolvia a condução da política monetária e a fiscalização da moeda circulante, o que de certa forma, prejudicava a sua necessária independência.

Em matéria econômica, o país passava por um período de elevado avanço nas exportações, e conseqüente crescimento econômico interno. Por outro lado, as importações estavam enfraquecidas, o que possibilitava um saldo favorável na balança comercial. Nesse contexto, o Brasil acumulava reservas, e isso lhe permitia negociar o pagamento da dívida externa com os credores estrangeiros.

Apesar da conquista de um momento de estabilidade na história econômica do país, um dos seus maiores problemas voltava a assolar a vida da população brasileira em meio aos anos 80. Tratava-se da elevada inflação, que alcançou o patamar de $235,5 \%$ no ano de 1985, uma verdadeira hiperinflação ${ }^{180}$.

Como forma de controlar esse mal, buscou-se combater os gastos públicos, reduzir em $10 \%$ o orçamento da União, e congelar os contratos e os empréstimos, para que o Estado não fosse refém de suas arrecadações, e precisasse lançar mão da emissão de papel-moeda além da quantidade em circulação.

Em fevereiro de 1986, foi implantado, pelo Presidente da República José Sarney, o Plano Cruzado, e, daí em diante, uma série de planos econômicos com o objetivo de vencer a inflação e controlar a emissão desmedida de moeda. Por meio deste primeiro plano, em vigor com base no Decreto-lei no 2.283/1986, o cruzeiro, moeda enfraquecida,

${ }^{180}$ FAUSTO, Boris (2004). Op. cit., p. 520-521. 
foi substituído por uma nova moeda, o cruzado, na razão de $\mathrm{Cr} \$ 1.000$ (mil cruzeiros) por $\mathrm{Cz} \$ 1,00$ (cruzado). À primeira vista, uma moeda extremamente forte.

Sobre os programas de estabilização do governo Sarney, JANSEN:

(...) eram editados, em sua maioria, através de 'pacotes' (do mesmo gênero das medidas de impacto herdadas da ditadura militar) que consistiam em várias normas sobre temas conexos publicados num só dia. O chamado Plano Cruzado II, por exemplo, foi baixado através de 15 (quinze) decretos-leis, todos do dia 21 de novembro de 1986, além de 14 decretos da mesma data, sem contar as normas de nível inferior. O denominado Plano Verão, por sua vez, consistiu em 8 (oito) medidas provisórias, todas de 15 de janeiro de $1989^{181}$.

Dentre as principais alterações promovidas na economia, aboliu-se o sistema baseado na indexação, e houve o congelamento, por prazo indeterminado, dos preços de bens, dos serviços, e da taxa de câmbio. Apenas para ilustrar a situação de hiperinflação pela qual o País passou, em termos práticos, os aluguéis foram congelados pelo período de um ano; e, o salário mínimo passou por um reajuste baseado nos vencimentos dos últimos seis meses, com promessa de futuros reajustes sempre que a inflação atingisse o índice de $20 \%$.

Fato interessante nesse momento de conscientização e busca pela estabilidade econômica do país, ocorreu quando a população, convocada a colaborar com a implementação do plano, passou a atuar como verdadeiro fiscal em supermercados e lojas comerciais, no intuito de controlar a inflação e assegurar que os preços se mantivessem congelados.

Com os preços dos bens inalterados e a concessão de um aumento salarial aos trabalhadores, o plano teve conseqüências totalmente diversas das planejadas, pois, a população passou a consumir como nunca antes, de produtos alimentícios a viagens ao exterior, o que ensejou o retorno da inflação e a cobrança, pelos vendedores ou fornecedores, de forma não declarada, de um custo adicional sobre os preços dos produtos, o chamado 'ágio', responsável por desequilíbrio maior na economia.

Com a valorização artificial da moeda interna, as importações atingiram índices elevados, no entanto, sem o respaldo do ingresso de capital estrangeiro, na forma de investimentos ou no aumento das exportações ${ }^{182}$.

\footnotetext{
${ }^{181}$ JANSEN, Letácio. Op. cit., p. 169-170.

${ }^{182}$ FAUSTO, Boris (2004). Op. cit., p. 523.
} 
Por fim, em 1987, em meio às crises monetária e financeira, o Brasil declarou moratória, suspendendo o pagamento dos juros da dívida externa aos bancos credores, por prazo indeterminado. Planos econômicos, visando debelar tais situações, foram desenhados, tais como: Cruzado, Bresser, Verão, Collor e Real (uma análise pormenorizada desses planos será contemplada, mais adiante, ainda no presente capítulo).

Constatou-se, como veremos a seguir, que, em um espaço de aproximadamente cinco anos, a moeda brasileira ainda passaria por mais quatro denominações distintas (cruzado novo, cruzeiro, cruzeiro real e real). Sem dúvida, um período de grande turbulência na economia interna, e de amplo prejuízo na manutenção da confiança de investidores externos.

Característica da época era, segundo JANSEN, com o qual concordamos, "a elaboração de normas ambíguas, disciplinando, na aparência, a desindexação, mas promovendo, na prática, a reindexação (como ocorreu com as muitas Medidas Provisórias, dentre as quais as de $n^{\circ} 38$, de 3 de fevereiro de 1989, e $n^{\circ} 75$, de 31 de julho de 1989). Pela quantidade de Medidas Provisórias publicadas no semestre inicial de 1989 - 37 (trinta e sete) - percebe-se a confusão reinante" ${ }^{\text {183 }}$.

De início, em 1990, por meio da Lei nº 8.024/1990, uma nova reforma monetária foi implantada no país, sendo reintroduzido o 'Cruzeiro', em substituição ao Cruzado. Na prática, o Cruzeiro não havia sido recolhido do mercado em sua integralidade.

Posteriormente, em 1993, devido aos exorbitantes índices inflacionários, e ao descontrole no orçamento, nova reforma monetária substituiu o 'Cruzeiro' pelo 'Cruzeiro Real' (CR\$). Para não perder o costume, em menos de um ano, sob o governo do Presidente Fernando Henrique Cardoso, o sistema monetário passou por uma nova reforma e a moeda passou a se chamar 'Real' (R\$).

Assim, em 1994, a Medida Provisória ${ }^{\circ} 542$ trouxe algum alento e esperança ao povo, assim como à grande parcela dos economistas e juristas. Por meio de uma reforma monetária, a antiga moeda circulante foi, em sua integralidade, substituída por uma nova moeda, o 'real', com limite de emissão fixado em R $\$$ 9,5 bilhões e taxa de câmbio em razão do dólar estabelecida em R \$ 1,00 (um real) para US\$1.00 (um dólar dos Estados Unidos). A nova moeda passou a ser garantida pelas reservas internacionais ${ }^{184}$.

\footnotetext{
183 JANSEN, Letácio. Op. cit., p. 170.

${ }^{184}$ SANT'ANA, José Antonio (1997). Op. cit., p. 17.
} 
Consoante as ponderações de LOPES e ROSSETTI, a estruturação da reforma que implantou o 'Plano Real' foi o mais bem sucedido empreendimento monetário concretizado no Brasil. Conforme relatam os autores:

A reforma monetária de 1994 foi a mais bem arquitetada entre todas as que antecederam nos anos 80 e 90, tanto pelas medidas preparatórias como pelos resultados. As duas medidas antecedentes mais importantes foram o ajuste das contas públicas, por medidas fiscais de emergência, e a criação de um novo indexador, a URV - unidade real de valor, com paridade fixa em relação ao dólar (1 URV = 1US\$). Introduzia-se, assim, no sistema monetário brasileiro uma nova unidade de conta, à qual todos os preços, começando compulsoriamente pelos salários, passaram a ser convertidos. A unidade de conta que se deteriorava era o cruzeiro real, que seria substituído pelo real, tão $\operatorname{logo}$ o processo de conversão de preços em URV estivesse estabelecido de fato e assimilado pela sociedade. A URV foi, assim, o embrião da nova moeda. Quando os preços "novos" (expressos pela nova denominação) estivessem assimilado, esta nova unidade de conta passaria a denominar-se, simplesmente, real, que então se introduziria como nova moeda, com todos os atributos requeridos de um instrumento monetário completo ter expressão física como meio circulante, ter poder liberatório e servir de meio de pagamento. $O$ tempo entre a criação da URV, sua assimilação como unidade de conta e a criação da nova unidade monetária substituta, o real, foi de apenas quatro meses, final de fevereiro a final de junho de $1994^{185}$. (sem grifo no original)

Os resultados iniciais alcançados com a nova moeda surpreenderam os analistas financeiros e o País entrou em uma nova fase econômica, com a redução, e praticamente eliminação, da inflação ${ }^{186}$. Após o período inicial de trinta dias, a medida provisória passou por uma reedição, e o limite de emissão da moeda foi elevado em $20 \%$. Com o objetivo de assegurar o equilíbrio nos preços internos, o Banco Central logo valorizou ainda mais a nova moeda, atribuindo-lhe a paridade de US\$ 0.84 (oitenta e quatro centavos de dólar dos Estados Unidos) para R \$ 1,00 (um real).

Ainda seguindo a avaliação crítica de LOPES e ROSSETTI, sobre o período de implementação do Plano Real:

Os agentes econômicos conviveram, assim, com um sistema bimonetário, cuja arquitetura conceitual estava fundamentada na convivência entre uma unidade de conta (URV) e um meio de pagamento de curso legal e

\footnotetext{
${ }^{185}$ LOPES, João do Carmo; ROSSETTI, José Paschoal, Op. cit., p. 43.

186 “(...) A taxa mensal de inflação passou de 46\% em junho de 1994 para 24,7\% em julho e atingiu apenas $0,6 \%$ em dezembro." BACHA, Carlos José. Macroeconomia aplicada à análise da economia. São Paulo: EDUSP, 2004, p. 240.
} 
poder liberatório irrecusável (CR\$). A nova moeda que emergiu desse sistema (R\$) reunificou essas funções. Esse engenhoso processo completou-se com uma "operação de guerra". No exato instante em que se suprimiu a URV como unidade de conta e o CR\$ como meio de pagamento, o meio circulante passou a ser substituído pelas moedas metálicas e cédulas da nova moeda, o real, R\$. E não se buscou apenas a substituição de um meio circulante por outro. Mais que isso: a paridade entre o dólar e a URV foi estendida ao real ${ }^{187}$.

Com o sucesso do plano, a moeda nacional resgatou as suas funções de unidade de valor, unidade de conta, reserva de valor, bem como o seu poder liberatório, tão esquecidas durante o período em que esteve desvalorizada e era emitida sem qualquer controle.

\subsection{1 - Reformas Monetárias e os Planos Econômicos}

Inicialmente deve-se entender que "reforma monetária" e "plano econômico" expressam conceitos distintos.

Reforma monetária pode ser conceituada como um movimento ou teoria que propõe um diferente sistema de emissão de dinheiro e financiamento da economia em relação ao sistema vigente. É a mudança do padrão monetário.

Plano econômico pode ser conceituado como uma escolha consciente e deliberada de prioridades econômicas pelas autoridades públicas. Trata-se de um conjunto de ações e diretrizes integradas, que têm como objetivo principal promover o desenvolvimento econômico e social de uma determinada região (cidade, município, estado ou país). Além disso, pode-se afirmar que, de alguma forma, todas as economias atuais envolvem planejamento e, com isso, quer-se dizer, sobretudo, planejamento estatal $^{188}$.

Conquanto normalmente confundam-se planos econômicos e planejamento econômico, vale ressaltar que "ainda que tais planos sejam de estabilização, transitórios, imediatistas, emergenciais, e não de longo prazo como seria o Planejamento Econômico, são válidos e admissíveis na ordem jurídica brasileira" ${ }^{189}$. São, pois, nessas circunstâncias, classificados como planos econômicos, mas não se enquadram como medidas de planejamento econômico, devido, justamente, à natureza das características listadas, todas incompatíveis com qualquer medida de médio e longo prazo.

\footnotetext{
${ }^{187}$ LOPES, João do Carmo; ROSSETTI, José Paschoal, Op. cit., p. 44.

${ }^{188}$ PASTORE, Affonso Celso; PINOTTI, Maria Cristina. Política Econômica, Vulnerabilidade Externa e Crescimento. O Brasil e o Mundo no Limiar do Novo Século. Rio de Janeiro: José Olympio, 1998, p. 91.

${ }^{189}$ BUITONI, Ademir. Op. cit., p. 275.
} 


\subsubsection{Reformas Monetárias}

No que se refere à dramática deterioração pela qual passou a moeda brasileira, apresentamos, a seguir, uma demonstração ${ }^{190}$, das várias reformas e a periódica mudança de padrão monetário pelas quais passou o sistema monetário brasileiro:

- CRUZEIRO, 1000 réis = Cr\$1 (com centavos), 01.11.1942: O Decreto-lei $\mathrm{n}^{\mathrm{o}}$ 4.791, de 05.10.1942 (D.O.U. de 06.10.42), instituiu o CRUZEIRO como unidade monetária brasileira, com equivalência a mil réis. Foi criado o centavo, correspondente à centésima parte do cruzeiro. Exemplo: 4:750\$400 (quatro contos, setecentos e cinqüenta mil e quatrocentos réis) passou a expressar-se Cr\$4.750,40 (quatro mil, setecentos e cinqüenta cruzeiros e quarenta centavos);

- CRUZEIRO (sem centavos) 02.12.1964: A Lei no 4.511, de 01.12.1964 (D.O.U. de 02.12.64), extinguiu a fração do cruzeiro denominada centavo. Por esse motivo, o valor utilizado no exemplo mencionado passou a ser escrito sem centavos: Cr\$4.750 (quatro mil, setecentos e cinqüenta cruzeiros);

- CRUZEIRO NOVO Cr\$1000 = NCr\$1 (com centavos) 13.02.1967: O Decreto-lei $\mathrm{n}^{\mathrm{o}}$ 1, de 13.11.1965 (D.O.U. de 17.11.65), regulamentado pelo Decreto $\mathrm{n}^{\mathrm{o}}$ 60.190, de 08.02.1967 (D.O.U. de 09.02.67), instituiu o Cruzeiro Novo como unidade monetária transitória, equivalente a um mil (sic) cruzeiros antigos, restabelecendo o centavo. O Conselho Monetário Nacional, pela Resolução $n^{\circ}$ 47, de 08.02.1967, estabeleceu a data de 13.02.67 para início de vigência do novo padrão. Exemplo: Cr\$ 4.750 (quatro mil, setecentos e cinqüenta cruzeiros) passou a expressar-se NCr\$ 4,75(quatro cruzeiros novos e setenta e cinco centavos);

- CRUZEIRO de NCr\$ para Cr\$ (com centavos) 15.05.1970: A Resolução $n^{\circ}$ 144, de 31.03.1970 (D.O.U. de 06.04.70), do Conselho Monetário Nacional, restabeleceu a denominação CRUZEIRO, a partir de 15.05.1970, mantendo o centavo. Exemplo: NCr\$4,75 (quatro cruzeiros novos e setenta e cinco centavos) passou a expressar-se $\mathrm{Cr} \$ 4,75$ (quatro cruzeiros e setenta e cinco centavos);

\footnotetext{
${ }^{190}$ Fonte: Banco Central do Brasil. Disponível em: $<$ http://www.bcb.gov.br/?REFSISMON $>$. Acesso em: 2 maio 2007.
} 
- CRUZEIRO (sem centavos) 16.08.1984: A Lei no 7.214, de 15.08.1984 (D.O.U. de 16.08.84), extinguiu a fração do Cruzeiro denominada centavo. Assim, a importância do exemplo, Cr\$ 4,75 (quatro cruzeiros e setenta e cinco centavos), passou a escrever-se $\mathrm{Cr} \$ 4$, eliminando-se a vírgula e os algarismos que a sucediam;

- CRUZADO Cr\$1000 = Cz\$1 (com centavos) 28.02.1986: O Decreto-lei $\mathrm{n}^{\mathrm{o}}$ 2.283, de 27.02.1986 (D.O.U. de 28.02.86), posteriormente substituído pelo Decreto-lei no 2.284, de 10.03.1986 (D.O.U. de 11.03.86), instituiu o CRUZADO como nova unidade monetária, equivalente a mil cruzeiros, restabelecendo o centavo. A mudança de padrão foi disciplinada pela Resolução $\mathrm{n}^{\mathrm{o}}$ 1.100, de 28.02.1986, do Conselho Monetário Nacional. Exemplo: Cr\$ 1.300.500 (um milhão, trezentos mil e quinhentos cruzeiros) passou a expressar-se $\mathrm{Cz} \$ 1.300,50$ (mil e trezentos cruzados e cinqüenta centavos);

- CRUZADO NOVO Cz\$ $1000=\mathrm{NCZ \$ 1}$ (com centavos) 16.01.1989: A Medida Provisória no 32, de 15.01.1989 (D.O.U. de 16.01.89), convertida na Lei $\mathrm{n}^{\mathrm{o}}$ 7.730, de 31.01 .1989 (D.O.U. de 01.02.89), instituiu o CRUZADO NOVO como unidade do sistema monetário, correspondente a um mil (sic) cruzados, mantendo o centavo. A Resolução $\mathrm{n}^{\circ}$ 1.565, de 16.01.1989, do Conselho Monetário Nacional, disciplinou a implantação do novo padrão. Exemplo: Cz\$1.300,50 (mil e trezentos cruzados e cinqüenta centavos) passou a expressar-se NCz\$1,30 (um cruzado novo e trinta centavos);

- CRUZEIRO de NCz\$ para Cr\$ (com centavos) 16.03.1990: A Medida Provisória n ${ }^{\circ} 168$, de 15.03.1990 (D.O.U. de 16.03.90), convertida na Lei $\mathrm{n}^{\mathrm{o}}$ 8.024, de 12.04.1990 (D.O.U. de 13.04.90), restabeleceu a denominação CRUZEIRO para a moeda, correspondendo um cruzeiro a um cruzado novo. Ficou mantido o centavo. A mudança de padrão foi regulamentada pela Resolução $\mathrm{n}^{\mathrm{o}}$ 1.689, de 18.03.1990, do Conselho Monetário Nacional. Exemplo: NCz\$ $1.500,00$ (mil e quinhentos cruzados novos) passou a expressar-se Cr $\$ 1.500,00$ (mil e quinhentos cruzeiros);

- CRUZEIRO REAL Cr\$ $1000=\mathrm{CR} \$ 1$ (com centavos) 01.08.1993: A Medida Provisória no 336, de 28.07.1993 (D.O.U. de 29.07.93), convertida na Lei $\mathrm{n}^{\mathrm{o}}$ 8.697, de 27.08 .1993 (D.O.U. de 28.08.93), instituiu o CRUZEIRO REAL, a partir de 01.08.1993, em substituição ao Cruzeiro, 
equivalendo um cruzeiro real a um mil (sic) cruzeiros, com a manutenção do centavo. A Resolução no 2.010, de 28.07.1993, do Conselho Monetário Nacional, disciplinou a mudança na unidade do sistema monetário. Exemplo: Cr\$ 1.700.500,00 (um milhão, setecentos mil e quinhentos cruzeiros) passou a expressar-se CR\$1.700,50 (mil e setecentos cruzeiros reais e cinqüenta centavos);

- REAL CR\$ $2.750=\mathrm{R} \$ 1$ (com centavos) 01.07.1994: A Medida Provisória n ${ }^{\circ}$ 542, de 30.06.1994 (D.O.U. de 30.06.94), instituiu o REAL como unidade do sistema monetário, a partir de 01.07.1994, com a equivalência de CR\$ 2.750,00 (dois mil, setecentos e cinqüenta cruzeiros reais), igual à paridade entre a URV e o Cruzeiro Real fixada para o dia 30.06.94. Foi mantido o centavo.

Como medida preparatória à implantação do Real, foi criada a URV - Unidade Real de Valor - prevista na Medida Provisória $n^{0}$ 434, publicada no D.O.U. de 28.02.94, reeditada com os números 457 (D.O.U. de 30.03.94) e 482 (D.O.U. de 29.04.94) e convertida na Lei $\mathrm{n}^{\mathrm{o}}$ 8.880, de 27.05.1994 (D.O.U. de 28.05.94). Exemplo: CR\$ 11.000.000,00 (onze milhões de cruzeiros reais) passou a expressar-se R $\$ 4.000,00$ (quatro mil reais).

De fato, pelo que se observa do exposto, é fácil constatar que a moeda atual - o real - é equivalente, hoje, a 2,75 quatrilhões de cruzeiros vigentes em 1964, em razão de quatro sucessivos cortes de três zeros, com base nos normativos mencionados, incluindo a divisão por 2.750 , determinada em $1^{\circ}$ de julho de 1994, o que não deixa de causar perplexidade em termos numéricos.

\subsubsection{Planos Econômicos}

Ao analisar o histórico econômico brasileiro, particularmente na segunda metade do século XX, pode-se afirmar que houve um insucesso das políticas de controle tarifário, de tabelamento de preços e de controle de custos de produção no intuito de reduzir a inflação (à exceção do Plano Real).

Durante os anos de 1970, a inflação esteve em torno de 50 por cento ao ano. Em 1979, elevou-se para 100 por cento e nesse nível permaneceu por três anos. Finalmente, em 1983, elevou-se para 200 por cento, mantendo esse nível nos três anos seguintes ${ }^{191}$.

${ }^{191}$ Dados obtidos em computado de números do IPEADATA. Disponível em: $<$ http://www.ipeadata.gov.br>. 
Na década de 1980, iniciou-se o período dos "planos econômicos", ou pacotes econômicos, que trouxeram novidades tais como o congelamento de preços. Na realidade, tais planos não podem ser assemelhados às técnicas de planejamento, que impõem a projeções de objetivos a médio e longo prazo, com seus respectivos instrumentos (a exceção é o Plano Real, como se verá adiante) ${ }^{192}$.

No presente ponto, serão analisados, em apertada síntese, os planos Cruzado, Bresser, Verão, Collor e Real, visando fortalecer o entendimento que se tem de tais planos econômicos brasileiros, a fim de bem conceber planos futuros, tendo em vista a emanada possibilidade do art. 174 de nossa Constituição ${ }^{193}$.

Houve, é certo, uma grande judicialização de todo esse debate, sobretudo na Justiça Federal do país, reconhecendo-se, em grande medida, como é fato público e notório, um alto grau de ilegalidades em muitos dos planos econômicos editados, especialmente na era pós-democracia ou pós-Constituição de 1988. Até hoje, os planos econômicos são encarados com grande desconfiança pela população brasileira.

\subsubsection{Plano Cruzado}

A aceleração da inflação ${ }^{194}$ na década de 80 ocorreu enquanto a economia brasileira enfrentava uma séria crise industrial. A renda per capita estava estagnada desde o ano de 1980. Um desequilíbrio financeiro estrutural do setor público, dotado de uma enorme dívida pública externa, pairava por trás da crise econômica. A aceleração da inflação e seus altos níveis eram sintomas dessa crise, e eram conseqüências indiretas da crise fiscal do Estado brasileiro ${ }^{195}$.

O Plano Cruzado foi implantado em 10 de março de 1986, através do Decreto-Lei $n^{\circ} 2.284 / 86$.

\footnotetext{
Acesso em: 26 nov. 2008.

192 AGUILLAR, Fernando Herren. Direito econômico: do Direito Nacional ao Direito Supranacional. São Paulo: Atlas, 2006, p. 160-161.

${ }^{193}$ Art. 174. Como agente normativo e regulador da atividade econômica, o Estado exercerá, na forma da lei, as funções de fiscalização, incentivo e planejamento, sendo este determinante para o setor público e indicativo para o setor privado.

${ }^{194}$ Para SANDRONI, a inflação é o aumento persistente dos preços em geral, de que resulta uma contínua perda do poder aquisitivo da moeda. Para maiores detalhes, ver: SANDRONI, Paulo. Novíssimo dicionário de economia. 11. ed. São Paulo: Best Seller, 2003.

${ }^{195}$ BRESSER - PEREIRA, Luiz Carlos. Os Dois Congelamentos de Preços no Brasil. Revista de economia política, vol. 8 , n 4, outubro - dezembro de 1988, p. 48-49.
} 
A instituição do Plano Cruzado por meio do Decreto-Lei $n^{\circ} 2.284 / 86$ foi exercício da competência constitucional atribuída ao Presidente da República por força da previsão do art. 55, II, CF/67, in verbis:

Art. 55. O Presidente da República, em casos de urgência ou de interêsse público relevante, e desde que não haja aumento de despesa, poderá expedir decretos-leis sôbre as seguintes matérias:

(...)

II - finanças públicas, inclusive normas tributárias; e

(...)

$\S 1^{\circ}$ - Publicado o texto, que terá vigência imediata, o decreto-lei será submetido pelo Presidente da República ao Congresso Nacional, que o aprovará ou rejeitará, dentro de sessenta dias a contar do seu recebimento, não podendo emendá-lo, se, nesse prazo, não houver deliberação, aplicar-se-á o disposto no $\S 3^{\circ}$ do art. 51 .

$\S 2^{\circ}$ A rejeição do decreto-lei não implicará a nulidade dos atos praticados durante a sua vigência.

Conforme o art. $1^{\mathrm{o}}$ do referido Decreto-lei, o cruzado passou a ser a moeda oficial Brasil:

Art. $1^{\circ}$ Passa a denominar-se cruzado a unidade do sistema monetário brasileiro, restabelecido o centavo para designar-se a centésima parte da nova moeda.

$\S 1^{\circ} \mathrm{O}$ cruzeiro corresponde a um milésimo do cruzado.

$\S 2^{\circ}$ As importâncias em dinheiro escrever-se-ão precedidas do símbolo CZ\$.

O Plano Cruzado foi a primeira versão de congelamento de preços lançada pelo Governo Federal. Em relação ao congelamento, o art. 35 do Decreto-Lei no 2284/86 dispõe que:

Art. 35. Ficam congelados todos os preços nos níveis do dia 27 de fevereiro de 1986.

$\S 1^{\circ}$ A conversão em cruzados dos preços a que se refere este artigo farse-á de conformidade com o disposto no $\S 1^{\circ}$ do artigo $1^{\circ}$, observando-se estritamente os preços a vista praticados naquela data, não se permitindo, em hipótese alguma, os preços a prazo com base de cálculo.

$\S 2^{\circ} \mathrm{O}$ congelamento previsto neste artigo, que se equipara, para todos os efeitos, a tabelamento oficial de preços, poderá ser suspenso ou revisto, total ou parcialmente, por ato do Poder Executivo, em função da estabilidade da nova moeda ou de fenômeno conjuntural. 
Com o Plano Cruzado adotou-se o entendimento de que o problema central da inflação brasileira, àquela altura, era o componente inercial ${ }^{196}$ : embora os proponentes do plano não desconhecessem a importância de outros fatores inflacionários, admitiam que a influência destes fosse, então, secundária. Essa crença foi reforçada por dois fatos: a constatação de que a inflação, no período anterior, parecia ter-se elevado por patamares; e a escalada de patamares, que em 1980 e 1983, parecia explicável por fenômenos pontuais (exemplos são a alta de juros e dos preços do petróleo e a correção monetária automática de todos os salários a cada seis meses) ${ }^{197}$. Sinteticamente pode-se dizer que visou a combater a inflação inercial por meio do congelamento dos preços e dos contratos. Em adição, suprimiu, pelo período de um ano, o caráter reajustável da Obrigação do Tesouro Nacional.

Durante os primeiros meses, o Plano Cruzado foi muito bem sucedido no controle da inflação. O plano teve um efeito impressionante sobre a economia, sendo que em um primeiro momento os preços chegaram a recuar, registrando uma deflação ${ }^{198}$.

Apesar do sucesso inicial, o plano tornou-se um fracasso, tanto por ter sido incapaz de erradicar a inflação quanto por ter provocado grandes distorções e uma acentuada crise econômica e financeira. O aspecto mais enfatizado do plano, entretanto, foi exatamente seu ponto mais frágil: o congelamento de preços. A euforia do público e a venda política de uma "inflação zero" levaram a uma forte fiscalização dos preços e impediram uma natural correção ${ }^{199}$.

A economia brasileira antes do Cruzado estava totalmente indexada, convivendo com taxas altas, mas quase estáveis de inflação. Com o Cruzado, o sistema de indexação foi eliminado. Quando a inflação reapareceu, em dezembro de 1986, a interdição legal da indexação provocou uma crise financeira. Nunca o número de insolvências e falências havia sido tão grande ${ }^{200}$.

\footnotetext{
${ }^{196}$ Esse componente era a inércia inflacionária, que faria com que o nível de inflação observado num período tendesse a se repetir nos períodos seguintes, mesmo na ausência de outros elementos determinantes de elevação de preços. Um dos primeiros autores a expor esse argumento foi Mário Henrique Simonsen. Nesse sentido, ver: SIMONSEN, Mário Henrique. Inflação: gradualismo x tratamento de choque. Rio de Janeiro: Apec, 1970.

${ }^{197}$ VERSIANO, Flávio Rabelo. Inflação e política antiinflacionária no Brasil. Brasília: Unb. Disponível em: < http://www.unb.br/face/eco/inteco/textosnet/2parte/inflacao_e_pol_inf.pdf >. Acesso em: 26 nov. 2008. ${ }^{198}$ AGUILLAR. Op. cit., p. 161.

199 ANDREZO, Andréa Fernandes; LIMA, Iran Siqueira. Mercado financeiro: aspectos históricos e conceituais. São Paulo: Thomson Learning, 2006, p. 159.

${ }^{200}$ BRESSER-PEREIRA. Op. cit., p. 54.
} 


\subsubsection{Plano Bresser}

Na primeira metade de 1987, a economia brasileira enfrentava novamente um momento de crise. Desde outubro de 1986, a inflação havia voltado a se acelerar significativamente atingindo níveis superiores a 20 por cento mensais; a indústria e o comércio davam sinais de desaceleração em seu crescimento; as contas externas ainda exibiam um comportamento bem abaixo dos padrões alcançados nos anos anteriores; uma aguda crise financeira atingia o setor privado; e uma grave crise fiscal desorganizava o setor público. Esses sinais indicavam forte crise conjuntural e financeira ${ }^{201}$.

O Plano Bresser, ao contrário do Plano Cruzado, não visava atingir inflação zero, nem eliminar a indexação, mas apenas conter o processo inflacionário ${ }^{202}$.

A instituição do Plano Bresser foi decorrência do Decreto-Lei $n^{\circ}$ 2.335/87, exercício da competência constitucional atribuída ao Presidente da República por força da previsão do art. 55, II, CF/67 (já citado e transcrito anteriormente).

O plano recebeu o nome do então Ministro da Fazenda do Governo Sarney, Luiz Carlos Bresser Pereira. Lançado em 12 de junho de 1987, através do Decreto-Lei $\mathrm{n}^{\circ}$ 2.335/87 (ver também os Decretos-Lei no 2.336 e nº 2.337, ambos de 1987).

O principal objetivo do Decreto foi controlar a inflação. Para isso, valeu-se especialmente do congelamento de preços e aluguéis, reajustes mensais de salários e vencimentos, instituindo a Unidade de Referência de Preços (URP) como referência monetária para fim de reajustes dos valores sobre os quais incidiu o congelamento. Nesse sentido, interessante a leitura do art. $1^{\circ}$ do Decreto-Lei $n^{\circ} 2.335 / 87$ :

Art. $1^{\circ}$ Ficam congelados, pelo prazo máximo de 90 (noventa) dias, todos os preços, inclusive os referentes a mercadorias, prestações de serviços e tarifas, nos níveis dos preços já autorizados ou dos preços à vista efetivamente praticados no dia 12 de junho de 1987.

Sobre a URP, o artigo 3. ${ }^{\circ}$ do Decreto-Lei $n^{\circ} 2.335 / 87$ dispõe que:

Art. $3^{\circ}$ Fica instituída a Unidade de Referência de Preços (URP) para fins de reajustes de preços e salários.

201 BRESSER-PEREIRA, Luiz Carlos. Plano de controle macroeconômico. Brasília, 21 jul. 1987, p. 8. Disponível em: <http://www.bresserpereira.org.br/Documents/MFazenda>. Acesso em: 25 nov. 2008.

${ }^{202}$ ANDREZO e LIMA. Op. cit., p. 159. 
$\S 1^{\circ}$ A URP, de que trata este artigo, determinada pela média mensal da variação do IPC ocorrida no trimestre imediatamente anterior, será aplicada a cada mês do trimestre subseqüente.

$\S 2^{\circ}$ Para efeito de cálculos futuros, a URP terá valor igual a 100 (cem) no dia 15 de junho de 1987 e permanecerá inalterada enquanto durar o congelamento.

É interessante atentar para o fato do congelamento objeto do Plano Bresser ter atingido também os negócios jurídicos com efeitos futuros, tal como se depreende da leitura do art. 14 do Decreto-Lei ${ }^{\circ} 2.335 / 87$, in verbis:

Art. 14. A norma de congelamento a que se refere o art. $1^{\circ}$ aplica-se:

I - aos contratos cujo objeto seja a venda de bens para entrega futura;

II - aos contratos de prestação de serviços contínuos ou futuros;

III - aos contratos cujo objeto seja a realização de obras.

O plano foi um fracasso. Dentre os motivos, pode-se mencionar que os comerciantes ressabiados com o primeiro congelamento, haviam desenvolvido metodologias para esquivarem-se dos efeitos dessa técnica de controle de preços. Como já esperavam por uma reedição da medida, fixaram artificialmente seus preços em valores elevados, oferecendo descontos no ato da compra. Assim, no momento do congelamento, as tabelas de comercialização não espelhavam a realidade dos preços, sendo muito superiores ao valor real ${ }^{203}$.

Na realidade, o Plano Bresser teve caráter emergencial. Não desindexou, não fixou a taxa de câmbio, não incluiu uma reforma monetária. A inflação que se seguiu decorreu sobretudo da recomposição de preços relativos que sucederam ao congelamento provisório e do "tarifaço", da "midi-desvalorização", não apresentando um ajuste fiscal suficiente ${ }^{204}$.

\subsubsection{Plano Verão}

Pouco tempo após o Plano Bresser, um outro plano, de meteórica vigência, foi implantado: o Plano Verão.

\footnotetext{
${ }^{203}$ AGUILLAR. Op. cit., p. 163.

${ }^{204}$ BRESSER-PEREIRA, Luiz Carlos. Heterodoxia e Ortodoxia no Plano Bresser. Revista Conjuntura Econômica, fev. 1993, p. 54.
} 
O Plano Verão foi instituído através da Medida Provisória $\mathrm{n}^{\mathrm{o}}$ 32/89, posteriormente convertida na Lei $\mathrm{n}^{\mathrm{o}} 7.730 / 89$. Com esse plano econômico, adotou-se o Cruzado Novo, tal como previsto no art. $1^{\circ}$ da Lei ${ }^{\circ} 7.730 / 89$ :

Art. $1^{\circ}$ Passa a denominar-se cruzado novo a unidade do sistema monetário brasileiro, mantido o centavo para designar a centésima parte da nova moeda.

$\S 1^{\circ} \mathrm{O}$ cruzado novo corresponde a um mil (sic) cruzados.

$\S 2^{\circ}$ As importâncias em dinheiro escrever-se-ão precedidas do símbolo $\mathrm{NCz} \$$.

O congelamento foi mais uma vez adotado, desta vez por prazo indeterminado. Os artigos $8^{\circ}$ e 11 da Lei $n^{\circ} 7.730 / 89$ são esclarecedores nesse sentido:

Art. $8^{\circ}$ Ficam congelados, por prazo indeterminados, todos os preços, inclusive os referentes a mercadorias, prestação de serviços e tarifas, nos níveis dos preços já autorizados pelos órgãos oficiais competentes ou dos preços efetivamente praticados no dia 14 de janeiro de 1989.

$\S 1^{\circ} \mathrm{O}$ congelamento de preços equipara-se, para todos os efeitos, ao tabelamento oficial.

$\S 2^{\circ}$ No caso de produtos sujeitos a controle oficial, os níveis de preços congelados são os autorizados pelos órgãos competentes, constantes das listas de preços oficiais homologadas pelos referidos órgãos.

$\S 3^{\circ}$ Os preços efetivamente praticados em 14 de janeiro de 1989, para venda a prazo, deverão ser ajustados de forma a eliminar a expectativa inflacionária neles contida, conforme dispuser o regulamento.

Art. 11. A norma de congelamento a que se refere o art. $8^{\circ}$ aplica-se:

I - aos contratos cujo objeto seja a venda de bens para entrega futura;

II - aos contratos de prestação de serviços contínuos ou futuros; e

III - aos contratos cujo objeto seja a realização de obras.

$\S 1^{\circ} \mathrm{O}$ preço dos serviços, obras ou fornecimentos realizados durante o mês de janeiro de 1989, relativos aos contratos de que trata este artigo, será reajustado de acordo com as cláusulas contratuais pertinentes.

$\S 2^{\circ}$ Nos contratos de que trata este artigo, a cláusula de reajuste com base na OTN adotará o IPC como índice substitutivo, observado o critério do $\S 2^{\circ}$ do art. 14 desta Lei.

Outras medidas, tais como a desindexação da economia e a proibição de correção monetária para o futuro e para os contratos em curso foram adotadas.

O Plano Verão, como mencionado, teve existência muito curta, tendo em vista o fracasso em que suas medidas redundaram, o que levou o então Presidente Fernando Collor 
de Mello, ao assumir a Presidência da República, em 15 de março de 1990, a optar pela implantação de um novo plano econômico: o Plano Collor.

\subsubsection{Plano Collor}

O Plano Collor é considerado uma das mais drásticas intervenções do Estado na economia no Brasil integrando o grupo de políticas de estabilização que incluíram limitação ou cancelamento da liquidez de haveres monetários ${ }^{205}$ (moeda manual e depósitos à vista) ou da conversibilidade de haveres financeiros em moeda ${ }^{206}$.

O nome oficial do plano é Plano Brasil Novo. Contudo, o nome "Plano Collor" prevaleceu, geralmente designando só o bloqueio dos haveres financeiros, sem referência às amplas medidas ${ }^{207}$ relacionadas com as finanças públicas, política de rendas, política cambial, comércio exterior e administração pública.

Trata-se de um Plano que foi amplamente questionado no Judiciário brasileiro.

Com a Medida Provisória ${ }^{\circ}$ 168/90, o Presidente Collor de Mello, no exercício da atribuição que lhe fora conferida pelo art. 62 da Constituição Federal, instituiu a moeda "cruzeiro" e dispôs sobre a liquidez dos ativos financeiros, dentre outras medidas. Posteriormente, a mencionada medida provisória foi convertida na Lei $n^{\circ} 8.024 / 90$, cujo art. $1^{\mathrm{o}}$ dispõe sobre a adoção do Cruzeiro:

\footnotetext{
Art. $1^{\circ}$ Passa a denominar-se cruzeiro a moeda nacional, configurando a unidade do sistema monetário brasileiro.

$\S 1^{\circ}$ Fica mantido o centavo para designar a centésima parte da nova moeda.

$\S 2^{\circ}$ Um cruzeiro corresponde a um cruzado novo.

$\S 3^{\circ}$ As quantias em dinheiro serão escritas precedidas do símbolo $\mathrm{Cr} \$$.
}

Já em relação à liquidez dos ativos, a título de exemplo das medidas adotadas com o plano, tem-se a restrição de liquidez dos depósitos à vista. O bloqueio dos valores

\footnotetext{
${ }^{205}$ Entende-se como bloqueio de liquidez o cancelamento ou a limitação da liquidez de haveres monetários ou do direito dos titulares de haveres financeiros não-monetários de convertê-los em moeda pelas regras vigentes, ou as duas coisas, restrições estas na forma de desvalorização nominal, alongamento compulsório de prazos de vencimento, repúdio ou anulação, retenção temporária ou confisco. Para maiores informações, consultar: CARVALHO, Carlos Eduardo F. (1996). Bloqueio da liquidez e estabilização: o fracasso do plano Collor. Campinas, Unicamp, Instituto de Economia, tese de doutorado, p. 5-8.

${ }^{206}$ CARVALHO, Carlos Eduardo F. As origens e a gênese do Plano Collor. Nova economia. Belo Horizonte, vol. 1, nº 16, jan./abr. 2006, p.105.

${ }^{207}$ O conjunto das medidas está na edição extra da Gazeta Mercantil de 17/3/1990 (nº 19.299).
} 
seguiria até 16 de setembro de 1991, data a partir da qual seriam devolvidos, em 12 parcelas mensais, tal como é explicitado a partir da leitura do artigo $5^{\circ}$ da Lei $n^{\circ} 8.024 / 90$ :

Art. $5^{\circ}$ Os saldos dos depósitos a vista serão convertidos em cruzeiros, segundo a paridade estabelecida no parágrafo segundo, do artigo $1^{\circ}$, obedecido o limite de $\mathrm{NCz} \$ 50.000,00$ (cinqüenta mil cruzados novos).

$\S 1^{\circ}$ As quantias que excederem o limite fixado no "caput" deste artigo serão convertidas, a partir de 16 de setembro de 1991, em doze parcelas mensais iguais e sucessivas, segundo a paridade estabelecida no $\S 2^{\circ}$ do art. $1^{\circ}$ desta lei. (Redação dada pela Lei $\mathrm{n}^{\circ}$ 8.088, de 1990).

$\S 2^{\circ}$ As quantias mencionadas no parágrafo anterior serão atualizadas monetariamente pela variação do BTN Fiscal, verificada entre o dia 19 de março de 1990 e a data da conversão, acrescida de juros equivalentes a $6 \%$ (seis por cento) ao ano ou fração 'pro rata'. (Redação dada pela Lei $\mathrm{n}^{\circ} 8.088$, de 1990).

$\S 3^{\circ}$ As reservas compulsórias em espécie sobre depósitos a vista, mantidas pelo sistema bancário junto ao Banco Central do Brasil, serão convertidas e ajustadas conforme regulamentação a ser baixada pelo Banco Central do Brasil.

A retenção de valores com o Plano Collor deu-se na proporção de aproximadamente 70 por cento, embora, no caso dos depósitos no overnight a retenção fosse de 80 por cento porque se estabeleceu para todos os depositantes um mínimo que poderiam transformar em cruzeiros através de uma taxa de conversão de 1 para 1 . Essa retenção foi reduzida nos dias seguintes ao plano através da abertura de uma série de possibilidades de conversão de cruzados em $\operatorname{cruzeiros}^{208}$.

A proposta de bloqueio da liquidez foi influenciada por três grandes vetores: primeiro, pelos dilemas da política monetária diante do ritmo de remonetização em programas antiinflacionários nas condições da época, sob influência das análises sobre o fracasso dos choques heterodoxos, especialmente o Plano Cruzado; em segundo; o destaque das implicações da elevada liquidez dos haveres financeiros (moeda indexada), considerada obstáculo para a política monetária pelas dificuldades colocadas para o controle da oferta de moeda e por transformar os juros altos em fator de aumento da liquidez; em terceiro, pela ênfase no rápido crescimento da dívida mobiliária interna e seu precário esquema de refinanciamento diário no mercado monetário ${ }^{209}$.

\footnotetext{
${ }^{208}$ BRESSER-PEREIRA, Luiz Carlos. As Incertezas do Plano Collor. Revista Brasileira de Economia, $\mathrm{n}^{\mathrm{o}}$ 45 (especial), jan. 1991, p. 85.

${ }^{209}$ CARVALHO, Carlos Eduardo. O plano Collor no debate econômico brasileiro. Pesquisa \& Debate, volume $11, \mathrm{n}^{\circ} 1$ (17), 2000, p. 116.
} 
O predomínio do caráter de bloqueio da liquidez é o que dá unidade às medidas adotadas e permite compreender os seus objetivos. O Plano Collor queria derrubar a inflação de imediato. Com o bloqueio se pretendia assegurar que as pressões inflacionárias não fossem repostas logo em seguida, como ocorrera de forma cada vez mais rápida e intensa nos três choques heterodoxos dos anos anteriores ${ }^{210}$.

Em poucos meses, a situação começou a deteriorar-se, visto que não foram criadas condições necessárias para a desindexação e o ajuste econômico. Além disso, devido às fortes pressões, uma parcela do dinheiro bloqueado foi liberada de forma desproporcional entre os setores da economia, o que levou a uma expansão da liquidez ${ }^{211}$.

Aos poucos, foram sendo editadas medidas de exceção ao bloqueio de liquidez para diversas empresas, além de pessoas em situação de saúde precária e idosos, dentre outros casos, aumentando a insatisfação da população que questionava os critérios adotados para as exceções. Mandados de segurança visando ao desbloqueio dos recursos começaram a ser deferidos pelos juízes, sob alegação de confisco ou empréstimo compulsório sem satisfazer às formalidades legais. Em 18 de março de 1990, três dias após a publicação de um pacote de medidas e em meio à enxurrada de ações judiciais, foi editada a Medida Provisória $n^{\circ} 173$, que vedou a concessão de medida liminar em mandado de segurança e em ações ordinárias e cautelares decorrentes de certas medidas provisórias $^{212}$ e, posteriormente, editou as Medidas Provisórias $n^{\circ} 181$ e 182, com conteúdo semelhante a de $\mathrm{n}^{\mathrm{o}} 173$, só que aplicável às leis em que havia se convertido as medidas provisórias $^{213}$.

A mencionada Medida Provisória $n^{\circ} 173$, atualmente sem efeito, em seu art. $1^{\circ}$ dispunha que:

\begin{abstract}
Art. $1^{\circ}$ - Não será concedida medida liminar em mandados de segurança em ações ordinárias e cautelares decorrentes das Medidas Provisórias números 151, 154, 160, 161, 162, 164, 165, 167 e 168, de 15 de março de 1990, aplicando-se-lhes o disposto no parágrafo único do artigo $5^{\circ}$ da Lei 4.348, de 26 de junho de 1964.
\end{abstract}

${ }^{210}$ CARVALHO, Carlos Eduardo. O fracasso do plano Collor: erros de execução ou de concepção? Economia. Niterói (RJ), vol. 4, nº 2, jul./dez. 2003, p. 289.

${ }^{211}$ ANDREZO e LIMA. Op. cit., p. 194.

${ }^{212}$ Referência às Medidas Provisórias números: 151, 154, 158, 160, 161, 162, 164, 165, 167 e 168.

${ }^{213}$ AGUILLAR. Op. cit., p. 165. 
Houve dois períodos distintos na trajetória do Plano Collor. O primeiro, do bloqueio até meados de maio, foi marcado pela rápida monetização, pela volta da inflação para o nível de 10 por cento ao mês e pela passagem do medo de uma recessão catastrófica para o medo de descontrole da oferta de moeda e da inflação. O segundo período começou no final de maio, quando se anunciou uma nova política, dita ortodoxa, com ênfase no controle da oferta de moeda e na supressão dos instrumentos típicos da convivência com a moeda indexada e com a inflação alta. $\mathrm{O}$ abandono desta política em setembro marcou a derrota do Plano Collor e deu lugar à fase de acomodação que se estendeu até o chamado Plano Collor II, no final de janeiro de $1991^{214}$.

Em $1^{\circ}$ de março de 1991, com o fracasso do Plano Collor, um novo pacote foi posto em vigor, através da Lei $\mathrm{n}^{\mathrm{o}} 8.177 / 91$. Tal pacote de medidas logo foi chamado de Plano Collor II. Dentre as medidas adotadas, destacam-se a definição de novas regras para a desindexação, extinguindo o Bônus do Tesouro Nacional (BTN) e outros índices monetários, além do que novas regras foram adotadas para a adaptação dos contratos em curso. Novamente as medidas foram incapazes de conter a elevação desenfreada dos $\operatorname{preços}^{215}$.

$\mathrm{Na}$ análise das determinantes do fracasso do bloqueio da liquidez, prevaleceu na época a interpretação de que o plano falhara devido à liberação descontrolada de valores retidos, provocada por pressões políticas e sociais sobre o governo e por erros de gerenciamento do programa. Decorre daí a tese de que o bloqueio da liquidez poderia ter obtido bons resultados se tivesse sido aplicado com rigor e coerência ${ }^{216}$.

\subsubsection{Plano Real}

Os planos econômicos da década de 1980 e início da década de 1990 caracterizaram-se, basicamente, por duas fases: a fase do controle do processo inflacionário por um período limitado (coerção); e a fase de liberação dos preços com o conseqüente descongelamento dos salários (desmoronamento). Abordando tais fases, SILVA afirma que:

(...) a etapa crítica dessa estrutura é a segunda fase, pois, proporciona o retorno dos índices inflacionários superiores ao período pré-estabilização e revela o desmoronamento do exercício de estabilização aplicado,

\footnotetext{
${ }^{214}$ CARVALHO, Carlos Eduardo. Op. cit., p. 284-285.

${ }^{215}$ AGUILLAR. Op. cit., p. 165.

${ }^{216}$ CARVALHO. Op. cit., p. 285.
} 
exponenciado pela incapacidade governamental de resistir às demandas e pressões sobre o gasto público, "incapacidade que podemos considerar como o fator responsável pelo isolamento e impotência da política monetária, por mais restritiva que ela tenha sido" ${ }^{217}$.

Tal como na década de 1980, comprovando o fracasso dos planos econômicos anteriormente analisados, os primeiros anos da década 1990 foram marcados no Brasil por um forte processo inflacionário ${ }^{218}$, com taxas mensais de dois dígitos (a inflação tinha alcançado níveis de 29,70 por cento ao mês, segundo o IGP-M ${ }^{219}$ de maio de 1993). Os planos anteriormente aplicados na economia brasileira levaram à constatação da total impraticabilidade de terapias convencionais e ortodoxas de combater, de maneira minimamente eficaz, a persistente e crescente inflação, que caracterizou os anos 1980 . Fazia-se necessário um novo e criativo diagnóstico desenvolvido pelas teses inercialistas $^{220}$.

Resumidamente, pode-se afirmar que o Plano Real ${ }^{221}$ foi implementado em três etapas: a primeira, com a aprovação do Fundo Social de Emergência (1993); a segunda, com a implantação da Unidade Real de Valor (URV) ${ }^{222}$ como padrão de valor monetário

${ }^{217}$ SILVA, Antonio Carlos da. O (des)ajuste global e os princípios da nova ordem econômica: o Brasil na Era dos Extremos. Revista Gestão \& Planejamento (G\&P), vol. 1, no 14 (1999). Disponível em: $<$ http://www.revistas.unifacs.br/index.php/rgb/article/viewFile/128/128>. Acesso em: 26 nov. 2008.

218 "Em comparação com outros países de inflação elevada, o Brasil é único em três aspectos. Primeiro, a inflação elevada de 1992-94 não parece ser derivada de um déficit público descontrolado; os dados reportados na Tabela 1 indicam que o déficit operacional consolidado do setor público tem estado próximo de zero desde 1990. Déficits operacionais substantivos foram fatores operativos no início e no prolongamento da inflação elevada (observe que o déficit médio foi de 5,2\% do PIB entre 1986-89), mas objetivamente não podem ser apontados como o principal fator explicativo da inflação elevada dos anos 90. Segundo, o Brasil tem uma inflação inercial particularmente forte, como resultado do uso generalizado da indexação pós-fixada para preços e salários. Terceiro, o estoque de moeda não consegue exercer o papel de uma âncora nominal porque a base monetária (moeda em poder do público mais reservas bancárias depositadas no Banco Central) é uma fração muito pequena do PIB e a regulamentação bancária (regime monetário) permite a expansão endógena da moeda. Assim, mesmo pequenos aumentos na razão base monetária/PIB são condizentes com taxas de inflação bastante elevadas. Nós defendemos neste trabalho que, no passado recente, a expansão da base monetária foi o resultado da inflação, e não uma causa independente dela." SACHS, Jeffrey; ZINI JR., Álvaro. A inflação brasileira e o "plano real". Revista de Economia Política, vol. 15, no 2 (58), abr./ jun. 1995, p .27.

${ }^{219}$ O IGP-M (Índice Geral de Preços do Mercado), calculado pela Fundação Getúlio Vargas, é composto pelo Índice de Preços ao Consumidor (IPC), Índice de Preços no Atacado (IPA) e Índice Nacional da Construção Civil (INCC). Dentre os três índices que compõe o IGP-M, o IPA tem maior influência no calculo, cujo peso é de 60 por cento enquanto que, o IPC tem peso de 30 por cento e o do INCC é de 10 por cento. O IGP-M é um dos índices mais utilizados no reajustes de contratos.

${ }^{220}$ CONCEIÇÃO, Octavio Augusto Camargo (Coord). Reavaliando os objetivos e os resultados do plano real. Análise, Porto Alegre, vol. 16, nº 2, p. 285-300, ago./dez. 2005, p. 286.

${ }^{221}$ A equipe dos criadores do Plano Real contou com a contribuição dos economistas Pedro Malan, Gustavo Franco, André Lara Resende, Edmar Lisboa Bacha e Pérsio Arida. Os três últimos economistas citados foram também formuladores do Plano Cruzado, em 1986, no governo José Sarney (1985-1990).

${ }^{222}$ Unidade Real de Valor (URV), instituída no Brasil em 1994, serviu como moeda de conta, na implantação do Plano Real, sendo usada como referencial para o Cruzeiro Real, até que fosse emitida, quando passou a 
(fevereiro de 1994); e a terceira, com o ganho de poder liberatório pela URV (1994). Além disso, há que se dizer que o plano foi fundado em três princípios básicos: forte apreciação da taxa de câmbio; aumento da taxa de juros real; e superávit fiscal primário.

Abordando as diferenças do Plano Real em relação aos planos econômicos anteriores, JANSEN refere o seguinte:

\begin{abstract}
A estrutura do Piano Real, de 1994, distinguiu-se das anteriores precisamente no que tange a essas normas de conversão e as tablitas. O Real, com efeito, não teve tablita, mas foi precedido por uma imposição compulsória da Unidade Real de Valor - URV, um indexador amplíssimo, tratado, explicitamente, pelo art. $1^{\circ}$ da Lei ${ }^{\circ} 8.880$, de 1994 , como moeda, embora jamais se tenha corporificado em peças monetárias $^{223}$.
\end{abstract}

O início de implementação do Plano Real aconteceu em 1993, conforme já mencionado, quando foi aprovado, no Congresso Federal, o Fundo Social de Emergência, envolvendo uma série de medidas fiscais de contenção dos gastos públicos, com aumento das receitas tributárias ${ }^{224}$.

O ajuste fiscal efetivado visou reduzir os desequilíbrios entre arrecadações e gastos públicos. A desindexação da economia resultou na eliminação da memória inflacionária. Houve um aumento da taxa de juros e dos depósitos compulsórios com a intenção de estabilizar a oferta e demanda por moeda e incentivar a entrada de investimentos estrangeiros. A adoção de um regime de câmbio nominal fixo, com o objetivo de manter a taxa de câmbio valorizada artificialmente, foi um fator que contribuiu para a queda da inflação gerando, porém, outras repercussões econômicas. A diminuição das barreiras tarifárias e não tarifárias acarretou uma acelerada abertura econômica e comercial, expondo o país à concorrência direta internacional. Ao mesmo tempo, observou-se uma forte tendência de desestatização da economia ${ }^{225}$.

Em 1994, a Lei ${ }^{\circ} 8.880$ instituiu a Unidade Real de Valor (URV) ao dispor sobre o Programa de Estabilização Econômica e o Sistema Monetário Nacional, dentre outras providências. $\mathrm{O}$ art. $1^{\circ}$ da Lei $n^{\circ} 8.880 / 94$ esclarece sobre a instituição da URV, in verbis:

\footnotetext{
ser chamada de Real.

223 JANSEN, Letácio. Op. cit., p. 180.

${ }^{224}$ CONCEIÇÃO. Op. cit., p. 289.

225 ARAÚJO, Erilton; DONHA, Talita. Discricionariedade na política monetária brasileira após o plano real: um teste baseado na correlação de longo prazo entre inflação e produto. IBMEC WORKING PAPER WPE - 61 - 2008. Disponível em: <www.ibmecsp.edu.br/pesquisa/download.php?recid=3166>. Acesso em: 26 nov. 2008, p. 2.
} 
Art. $1^{\circ}$ - Fica instituída a Unidade Real de Valor - URV, dotada de curso legal para servir exclusivamente como padrão de valor monetário, de acordo com o disposto nesta Lei.

$\S 1^{\circ}$ - A URV, juntamente com o Cruzeiro Real, integra o Sistema Monetário Nacional, continuando o Cruzeiro Real a ser utilizado como meio de pagamento dotado de poder liberatório, de conformidade com o disposto no art. $3^{\circ}$.

$\S 2^{\circ}$ - A URV, no dia $1^{\circ}$ de março de 1994 , corresponde a CR\$ 647,50 (seiscentos e quarenta e sete cruzeiros reais e cinqüenta centavos).

A URV, média de três índices de preços representativos da economia - IPC/FIPE, IPCA/IBGE e IGP-M/FGV - objetivou "induzir" a economia a encontrar um vetor de preços sustentável, buscando, assim, a desindexação através da indexação geral dos contratos $^{226}$.

A previsão legal do Plano Real encontra-se prevista na Lei $n^{\text {o }}$ 9.069/95 (anteriormente a matéria encontrava-se na Medida Provisória $\left.n^{\circ} 1.027 / 95\right)$, responsável pela conversão da URV em Real a partir de $1 .^{\circ}$ de julho de 1994, tal como disposto no art. 1. ${ }^{\circ}$ da Lei $n^{\circ} 9.069 / 95$, tal como segue:

Art. $1^{\circ}$ A partir de $1^{\circ}$ de julho de 1994, a unidade do Sistema Monetário Nacional passa a ser o REAL, que terá curso legal em todo o território nacional.

$\S 1^{\circ}$ As importâncias em dinheiro serão grafadas precedidas do símbolo $\mathrm{R} \$$.

$\S 2^{\circ}$ A centésima parte do REAL, denominada "centavo", será escrita sob a forma decimal, precedida da vírgula que segue a unidade.

$\S 3^{\circ}$ A paridade entre o REAL e o Cruzeiro Real, a partir de $1^{\circ}$ de julho de 1994, será igual à paridade entre a Unidade Real de Valor - URV e o Cruzeiro Real fixada pelo Banco Central do Brasil para o dia 30 de junho de 1994.

$\S 4^{\circ} \mathrm{A}$ paridade de que trata o parágrafo anterior permanecerá fixa para os fins previstos no art. $3^{\circ}, \S 3^{\circ}$, da Lei $n^{\circ} 8.880$, de 27 de maio de 1994 , e no art. $2^{\circ}$ desta Lei.

$\S 5^{\circ}$ Admitir-se-á fracionamento especial da unidade monetária nos mercados de valores mobiliários e de títulos da dívida pública, na cotação de moedas estrangeiras, na Unidade Fiscal de Referência - UFIR e na determinação da expressão monetária de outros valores que necessitem da avaliação de grandezas inferiores ao centavo, sendo as frações resultantes desprezadas ao final dos cálculos.

${ }^{226}$ FERRARI FILHO, Fernando. O legado do Plano Real: uma estabilização sem crescimento econômico? Revista Análise Econômica da Faculdade de Ciências Econômicas. 35. ed., Porto Alegre, ano 19, mar. 2001, p. 4. 
Com o ganho de poder liberatório pela URV houve a substituição do cruzeiro real pelo real como meio de troca, unidade de conta e reserva de valor. Somou-se a isso, a adoção de medidas que estabeleceram regras de emissão monetária e definiram a paridade máxima entre o real e o dólar, condições imprescindíveis para assegurar a estabilidade monetária.

A política cambial desempenhou papel fundamental no processo de estabilização econômica. Em um primeiro momento, até janeiro de 1995, observou-se uma acentuada valorização do câmbio e uma maior abertura da economia, resultando em maior exposição da produção nacional à oferta de bens e serviços de origem externa. Posteriormente, o regime cambial adotado em resposta à crise mexicana, em 1995, foi marcado por desvalorizações cambiais graduais que visaram à recuperação dos desequilíbrios nas contas externas, causadas pela sobrevalorização do câmbio. Finalmente, adotou-se, em janeiro de 1999, o regime de livre flutuação. Repetindo experiências internacionais de mudanças semelhantes, houve uma imediata e significativa depreciação da taxa de câmbio, seguida de um recuo parcial e, algum tempo depois, de uma relativa acomodação ${ }^{227}$.

Analisando a relação entre o Plano Real e o cenário internacional da época de sua implementação, pode-se afirmar que as mudanças estruturais na ordem internacional (neoliberalismo, reestruturação produtiva e a globalização impulsionados pelas grandes corporações transnacionais, instituições comerciais e financeiras multilaterais tais como o FMI, o BIRD, o BID e a OMC) são parte importante para a compreensão do sucesso dos planos de estabilização na década de 1990, a exemplo do Plano Real ${ }^{228}$.

No âmbito do Mercosul, a valorização do real ajudou a atenuar a grave situação cambial da Argentina que, desde 1991, adotara a paridade cambial entre o peso e o dólar norte-americano. Nesse sentido, LUZ aborda a questão:

Com o plano real, a nossa moeda se tornou mais valorizada do que a moeda argentina. Com isso, nós começamos a inverter o fluxo comercial com a Argentina. Passamos a ser mais compradores do que vendedores. O problema do Balanço de Pagamentos se tornou nosso e deixou de ser deles $^{229}$.

${ }^{227}$ MOTTA, João Ricardo da. Trajetória do plano real. Nota Técnica/Câmara dos Deputados, jul. 2008, p. 4. Disponível em: $<$ http://apache.camara.gov.br/portal/arquivos/Camara/internet/publicacoes $>$. Acesso em: 27 nov. 2008.

${ }^{228}$ NOVELLI, José Marcos Nayme. As teorias sociológicas da inflação e o Plano Real: conflito e coalizão. Revista Política \& Sociedade, $\mathrm{n}^{\circ}$ 6, abr. 2005, p. 122.

${ }^{229}$ LUZ, Rodrigo. Relações econômicas internacionais. São Paulo: Campus, 2005, p. 196. 
O objetivo principal do Plano Real foi reduzir a inflação crônica que persistia por três décadas. Diferentemente das tentativas fracassadas anteriores, o plano obteve êxito no controle da inflação que prejudicava consideravelmente a economia brasileira. O Plano Real é considerado como instrumento de estabilização dos preços para o cenário inflacionário que existia até 1994 e frente à velocidade com que a inflação caiu e se estabilizou.

A novidade a partir de 1999 foi que, após a adoção de um regime de livre flutuação do câmbio - no contexto do mercado de câmbio brasileiro, cujas principais características são analisadas no tópico a seguir -, a estabilidade de preços não mais pode estar vinculada a uma âncora cambial ${ }^{230}$. Assim, implementou-se um sistema de metas da inflação, cujo objetivo é sinalizar a manutenção do compromisso com a estabilização econômica.

A despeito do controle inflacionário, o Plano Real provocou ou acelerou algumas distorções. As principais foram: o crescente aumento do estoque da dívida pública - a razão dívida líquida total do setor público em relação ao PIB cresceu 73,6 por cento, entre 1994 e 2000 - e as dificuldades do sistema financeiro em operar em um cenário sem imposto inflacionário - o que obrigou o governo a lançar o Programa de Estímulo à Reestruturação e ao Fortalecimento do Sistema Financeiro Nacional (PROER), a partir de regras estabelecidas pelo Banco Central. Aliadas a estas distorções recrudesceram questões como desemprego, desnacionalização progressiva da economia brasileira e aumento da vulnerabilidade da economia nacional frente às crises externas ${ }^{231}$.

Sem desconsiderar as carências e dificuldades existentes à época da implementação do Plano Real, pode-se afirmar que esse plano foi o único programa bemsucedido de controle da inflação no país, após décadas de esforços concentrados nesse sentido.

\subsection{2 - O Mercado de Câmbio no Brasil}

Denomina-se taxa de câmbio o preço de uma moeda estrangeira medido em unidades ou frações (centavos) da moeda nacional. Quando se diz, por exemplo, em

\footnotetext{
${ }^{230}$ Âncora cambial é o recurso utilizado pelo governo para brecar a cotação de uma moeda em relação ao dólar, por exemplo. Isso acontece ao se fixar o valor da moeda na taxa cambial. Este foi o instrumento utilizado pela equipe econômica brasileira até 1999 , quando US\$1,00 passou a valer $R \$ 1,21$, taxa definida para a conversão. O objetivo era segurar a inflação.

${ }^{231}$ CONCEIÇÃO. Op. cit., p. 291.
} 
relação ao dólar dos Estados Unidos, que a taxa de câmbio brasileira é 4,00, significa que um dólar dos Estados Unidos custa quatro reais, no caso, porque a moeda estrangeira mais negociada no Brasil é o dólar dos Estados Unidos, fazendo com que a cotação mais comumente utilizada seja a dessa moeda. A taxa de câmbio pode ser separada em taxa de venda e taxa de compra, termos que se aplicam sempre ao banco ou outro agente autorizado a operar pelo Banco Central: a taxa de venda é o preço que o banco cobra para vender a moeda estrangeira (a um importador, por exemplo), enquanto a taxa de compra reflete o preço que o banco aceita pagar pela moeda estrangeira que lhe é ofertada (por um exportador, por exemplo) $)^{232}$.

O Banco Central brasileiro, até, aproximadamente, janeiro de 1999, fixava a taxa de câmbio do País através de bandas estreitas ou "minibandas" dentro de faixas mais largas, sendo que a conversão de outras moedas para o real transitava, necessariamente, pelo dólar dos Estados Unidos ${ }^{233}$.

A taxa de câmbio no Brasil sempre foi conduzida através de "tentativa e erro", como, de certa forma, ainda permanece ainda hoje, quando vista em termos de metas e pontos de referência. Na década de 1970, o objetivo era, prioritariamente, a promoção às exportações, por meio da taxa de câmbio (cruzado/dólar), que permanecia em linha com as taxas de câmbio ponderadas em relação ao comércio externo ${ }^{234}$.

O Banco Central do Brasil, autarquia federal integrante do Sistema Financeiro Nacional (SFN), foi criado de forma a atuar como promotor da estabilidade do poder de compra da moeda pátria, de forma que possui como seus objetivos permanentes a manutenção de adequada liquidez da economia; das reservas internacionais brasileiras sempre em nível adequado; do estímulo à poupança de forma a viabilizar as necessidades de investimento do país; e da estabilidade e promoção de um permanente aperfeiçoamento do Sistema Financeiro Nacional ${ }^{235}$.

Até a criação do Banco Central, tínhamos como autoridades monetárias a Superintendência da Moeda e do Crédito (SUMOC), o Banco do Brasil (BB) e o Tesouro Nacional. Elas acabavam exercendo, conjuntamente, funções típicas de Banco Central, de forma paralela às atividades que regularmente desenvolviam. Mesmo com a criação do Banco Central, que atua na qualidade de banco emissor, inicialmente seguia-se a realização

${ }^{232}$ GAROFALO FILHO (2004). Op. cit., p. 253.

${ }^{233}$ CURRO, Raul Jorge de Pinho. O MERCOSUL e o mercado de câmbio. Dissertação de mestrado, Faculdade de Direito da Universidade de São Paulo, 2004, p. 37.

${ }^{234}$ Idem.

${ }^{235}$ Ibidem, p. 40. 
de emissões em face das necessidades oriundas do Banco do Brasil. Ou seja, o Banco Central não detinha exclusividade dos depósitos das instituições financeiras, as quais faziam o recolhimento de suas reservas voluntárias diretamente no Banco do Brasil, além de outras disfunções ${ }^{236}$.

Aliás, no que tange à emissão de moeda, VERÇOSA ${ }^{237}$ relata e esclarece, com a peculiar autoridade que tem nesta matéria, que "numa primeira etapa da história dos bancos, todos eles emitiam moeda, fato ocorrido até a metade do séc. XIX..." e que "as emissões dizem respeito a certificados de ouro, entregues em troca de metais preciosos depositados nos bancos por comerciantes, desejosos de se prevenir contra roubos. Esse foi o caso, por exemplo, do Banco de Amsterdã, fundado em 1509".

Ainda sobre o assunto abordado, afirma o referido autor o seguinte:

(...) procurando evitar o crescimento indiscriminado da moeda interna, a Constituição Federal, em seu artigo 164, estabeleceu que o Banco Central do Brasil tem a competência privativa para emiti-la, sendo-lhe vedado conceder empréstimos ao Tesouro Nacional, seja direta, seja indiretamente $^{238}$.

Em 1985, buscou-se o reordenamento financeiro governamental, o qual se deu com a separação das contas e funções do $\mathrm{BACEN}^{239}$, Banco do Brasil e Tesouro Nacional. No ano seguinte, deu-se a extinção da conta movimento e o fornecimento de recursos do BACEN ao Banco do Brasil passou a ser identificado nos orçamentos de ambas as instituições, de que se acabou com os suprimentos automáticos que prejudicavam a atuação do Banco Central ${ }^{240}$.

Em relação ao tratamento cambial desempenhado pelo Banco Central, é interessante destacar as seguintes funções:

- a atuação asseguradora do funcionamento regular do mercado de câmbio;

\footnotetext{
236 “Os grandes interesses contrários à criação de um banco central, localizados no Banco do Brasil, transformaram essa instituição no centro do imbróglio monetário, fiscal e financeiro que perpassa longos períodos de nossa história. Por um lado, as relações históricas entre as autoridades monetárias e as autoridades fiscais sempre foram pouco transparentes, e seus canais de comunicação mantiveram-se mais ou menos ocultos. Por outro, as relações das autoridades monetárias e suas políticas com os bancos privados também nunca foram claramente definidas." CORAZZA, Gentil. O Banco Central do Brasil: evolução histórica e institucional. Perspectiva Econômica. vol. 2, n 1, jan./jun. 2006 p. 3.

${ }^{237}$ VERÇOSA, Haroldo Malheiros Duclerc. Op. cit., p. 46.

${ }^{238}$ Ibidem, p. 48.

${ }^{239}$ BANCO CENTRAL DO BRASIL, sendo essa sigla - BACEN - a mais usada ao se referir à Autarquia.

${ }^{240}$ CURRO, Raul Jorge de Pinho. Op. cit., p. 52.
} 
- a estabilidade relativa das taxas de câmbio e o equilíbrio do balanço de pagamentos;

- a administração de reservas cambiais do País;

- a promoção, na qualidade de agente do governo federal, da contratação de empréstimos e emissão de títulos no exterior;

- o acompanhamento e controle do movimento de capitais, incluindo aqueles relativos a acordos com entidades internacionais, e aqueles que se refiram à recuperação de créditos do governo brasileiro no exterior;

- as negociações, em nome do governo brasileiro, com instituições financeiras e organismos financeiros internacionais.

Nesse sentido, dispõe o art. 11 da Lei ${ }^{\circ}$ 4.595/64:

Art. 11. Compete ainda ao Banco Central da República do Brasil;

I - Entender-se, em nome do Governo Brasileiro, com as instituições financeiras estrangeiras e internacionais;

II - Promover, como agente do Governo Federal, a colocação de empréstimos internos ou externos, podendo, também, encarregar-se dos respectivos serviços;

III - Atuar no sentido do funcionamento regular do mercado cambial, da estabilidade relativa das taxas de câmbio e do equilíbrio no balanço de pagamentos, podendo para esse fim comprar e vender ouro e moeda estrangeira, bem como realizar operações de crédito no exterior, inclusive as referentes aos Direitos Especiais de Saque, e separar os mercados de câmbio financeiro e comercial; (Redação dada pelo Decreto-lei $\mathrm{n}^{0} 581$, de $14 / 5 / 1969)$.

IV - Efetuar compra e venda de títulos de sociedades de economia mista e empresas do Estado;

$\mathrm{V}$ - Emitir títulos de responsabilidade própria, de acordo com as condições estabelecidas pelo Conselho Monetário Nacional;

VI - Regular a execução dos serviços de compensação de cheques e outros papéis;

VII - Exercer permanente vigilância nos mercados financeiros e de capitais sobre empresas que, direta ou indiretamente, interfiram nesses mercados e em relação às modalidades ou processos operacionais que utilizem;

VIII - Prover, sob controle do Conselho Monetário Nacional, os serviços de sua Secretaria.

$\S 1^{\circ}$ No exercício das atribuições a que se refere o inciso VIII do artigo 10 desta lei, o Banco Central do Brasil poderá examinar os livros e documentos das pessoas naturais ou jurídicas que detenham o controle acionário de instituição financeira, ficando essas pessoas sujeitas ao disposto no artigo $44, \S 8^{\circ}$, desta lei. (Incluído pelo Decreto-lei $\mathrm{n}^{\circ} 2.321$. de 25/2/1987).

$\S 2^{\circ} \mathrm{O}$ Banco Central da República do Brasil instalará delegacias, com autorização do Conselho Monetário Nacional, nas diferentes regiões geo- 
econômicas do país, tendo em vista a descentralização administrativa para distribuição e recolhimento da moeda e o cumprimento das decisões adotadas pelo mesmo Conselho ou prescritas em lei. (Renumerado pelo Decreto-lei $n^{\circ} 2.321$, de 25/2/1987).

Diante disso, verifica-se que além da execução da política cambial, ao zelar pela sua coerência com a política monetária, o Banco Central busca investir as reservas internacionais utilizando um padrão adequado de segurança, liquidez e rentabilidade. Promove, outrossim, a regulamentação necessária dos fluxos cambiais, relativos ao comércio exterior e ao movimento de capitais financeiros, e viabiliza o relacionamento financeiro global entre o país e os mercados internacionais.

O Tratado de Assunção ${ }^{241}$, estabelece que o Banco Central é um membro do Grupo Mercado Comum, e coordena o trabalho dos subgrupos técnicos na qualidade de Órgão Executivo. A propósito, o art. 14 do Tratado de Assunção refere o seguinte:

Artigo 14 - O Grupo Mercado Comum estará integrado por quatro membros titulares e quatro membros alternos por país, que representem os seguintes órgãos públicos:

- Ministério das Relações Exteriores;

- Ministério da Economia seus equivalentes (áreas de indústria, comércio exterior e ou coordenação econômica);

- Banco Central.

Ao elaborar e propor medidas concretas no desenvolvimento de seus trabalhos, até 31 de dezembro de 1994, o Grupo Mercado Comum poderá convocar, quando julgar conveniente, representantes de outros órgãos da Administração Pública e do setor privado.

A despeito da previsão de grupo de trabalho em área monetária, considera-se o Tratado de Assunção rarefeito de previsões normativas abordando o âmbito monetário, tal como expresso nas esclarecedoras palavras de VERÇOSA:

Apesar de termos diante de nós toda a experiência da construção da União Européia, que segue avante, apesar das grandes dificuldades que se têm apresentado, o Tratado de Assunção é extremamente pobre nas regras sobre política monetária e cambial e, conseqüentemente, praticamente nada se instituiu ainda a respeito das relações entre os bancos centrais dos Estados-membros e da unificação dos seus sistemas bancários. E, quanto à futura existência de um Banco Central do Mercosul, é completamente silente, embora reconheça, em seu preâmbulo, "a evolução dos acontecimentos internacionais, em especial a

${ }^{241}$ Assinado em 26 de março de 1991, pela Argentina, Brasil, Paraguai e Uruguai, prevendo a formação, ocorrida em 31 de dezembro de 1994, de um mercado comum entre esses 4 (quatro) países. 
consolidação de grandes espaços econômicos, e a importância de lograr uma adequada inserção internacional para seus países" ${ }^{\text {,242 }}$.

O Banco Central brasileiro terminou por assumir a coordenação do Subgrupo $\mathrm{n}^{\circ} 4$, o qual possui como atribuições o que tange a políticas monetária e fiscal, quando relacionadas com o comércio. O Subgrupo no 4 está vinculado ao Grupo Mercado Comum, que é responsável por temas que dizem respeito aos bancos centrais, a saber, exemplificativamente, o pertinente a: "regime cambial, movimentos de capitais, sistema financeiro, seguro, mercado de capitais e promoção, e a proteção de investimentos" ${ }^{\text {,243 }}$.

${ }^{242}$ VERÇOSA, Haroldo Malheiros Duclerc. Op. cit., p. 473-474.

${ }^{243}$ CURRO, Raul Jorge de Pinho. Op. cit., p. 48. 


\section{CAPÍTULO IV}

\section{A EXPERIÊNCIA DA MOEDA ÚNICA NA UNIÃO EUROPÉIA}

\section{1 - Histórico}

O símbolo monetário ${ }^{244}$ de um país desempenha, segundo a teoria econômica, as mais variadas funções, as quais foram estudadas, individualmente, no Capítulo I )

Historicamente, a partir do surgimento dos estados nacionais no século XIX, a moeda passou a ser considerada um dos símbolos da unidade nacional, juntamente com a bandeira. A fortaleza e credibilidade do símbolo monetário de um país dependem, intimamente, de seu potencial econômico e da saúde estrutural de seu aparelho produtivo. Uma economia débil e vulnerável terá, como corolário, uma moeda fraca e desprestigiada carreando reflexos negativos à economia nacional.

Desde a queda do Império Romano, e a partir do enfraquecimento do Império dos Francos fundado por Carlos Magno no Século IX, passando pelas Cruzadas na Idade Média, o Renascimento, a Guerra dos Cem Anos, a Revolução Francesa, a Revolução Industrial, o imperialismo do Século XIX e as duas grandes Guerras do Século XX, a Europa não havia conquistado um período de mais de cinqüenta anos ininterruptos de paz como o iniciado a partir da constituição das Comunidades na década de $1950^{245}$.

Compreende-se o sucesso das Comunidades, precursoras da União Européia, por diversos fatores que no decorrer deste capítulo passamos a expor, mas que podem ser resumidos no alcance que tal bloco atingiu no que diz respeito ao que VERÇOSA muito bem expõe no seguinte trecho:

\footnotetext{
244 "Assim como os sinais lingüísticos, os símbolos monetários falam, transmitem informações e criam experiências compartilhadas. A confiança na moeda é desta forma o fruto de uma "comunicação via moeda" que logrou. Daí que nós não podemos esperar compreender o jogo da moeda se nós negligenciarmos seus aspectos comunicacionais". THERET, Bruno. Op. cit., p. 12.

245 “A Europa de 1957 era uma Europa cansada, destruída depois de duas guerras mundiais em menos de 50 anos. Paz, Liberdade e Segurança eram os valores desejados pelos Países. A divisão da Alemanha, através do Muro de Berlim, e a ameaça comunista que vinha do Leste fazia recear o aparecimento de novos conflitos. Daí que, em 1951, tivesse surgido a CECA. Ao pôr-se (sic) em comum as produções de carvão e aço sob a alçada de uma autoridade comum estava a retirar-se da mão dos possíveis estados beligerantes a matériaprima para a guerra." O Futuro da Europa. Instituto de Estudos Estratégicos e Internacionais, $\mathrm{n}^{\mathrm{o}} 3$, mar./abr. de 2007, p. 4. Disponível em: <http://www.ieei.pt/files/070326_boletim_versao2.pdf>. Acesso em: 3 dez. 2008.
} 
A criação de blocos econômicos regionais tem procurado, no campo financeiro, harmonizar os interesses dos Estados participantes e, até mesmo, criar uma única moeda interna. Ainda não há experiência suficiente nessa área para poder-se indicar os caminhos mais aceitáveis, dependendo o tema da elaboração de estudos permanentes, buscando as melhores soluções para o problema, de forma a que se estabeleça um desejável equilíbrio das vontades supranacional e individuais de cada membro da comunidade $^{246}$.

Desde a queda do Império Romano, e a partir do enfraquecimento do Império dos Francos fundado por Carlos Magno no Século IX, passando pelas Cruzadas na Idade Média, o Renascimento, a Guerra dos Cem Anos, a Revolução Francesa, a Revolução Industrial, o imperialismo do Século XIX e as duas grandes Guerras do Século XX, a Europa não havia conquistado um período de mais de cinqüenta anos ininterruptos de paz como o iniciado a partir da constituição das Comunidades na década de $1950^{247}$.

Para entender como a União Européia chegou até seu atual estágio de desenvolvimento e integração econômico-monetária faz-se necessário apresentar a integração desenvolvida na década de 1950 através das "Comunidades". As Comunidades Européias são a base da atual União Européia.

Em 1951, foi assinado o Tratado de Paris, pelo qual se criou a Comunidade Européia do Carvão e do Aço (CECA). Os Estados-Membros foram seis: França, Itália, Alemanha, Bélgica, Holanda e Luxemburgo. A constituição da CECA foi idealizada como forma de impedir futuros conflitos entre a França e a Alemanha, em razão do interesse da indústria alemã de aço sobre os depósitos de minério (em território francês), bem como do interesse da indústria francesa pelas jazidas alemãs de carvão.

Em maio de 1955, os Estados do BENELUX ${ }^{248}$ remeteram um memorando aos demais Estados-Membros da CECA propondo prosseguir com o estabelecimento de uma Europa unida mediante o desenvolvimento de instituições comuns, a fusão progressiva da

\footnotetext{
${ }^{246}$ VERÇOSA, Haroldo Malheiros Duclerc. Op. cit., p. 453.

247 “A Europa de 1957 era uma Europa cansada, destruída depois de duas guerras mundiais em menos de 50 anos. Paz, Liberdade e Segurança eram os valores desejados pelos países. A divisão da Alemanha, através do Muro de Berlim, e a ameaça comunista que vinha do Leste fazia recear o aparecimento de novos conflitos. Daí que, em 1951, tivesse surgido a CECA. Ao pôr-se (sic) em comum as produções de carvão e aço sob a alçada de uma autoridade comum estava a retirar-se da mão dos possíveis estados beligerantes a matériaprima para a guerra." O Futuro da Europa. Instituto de Estudos Estratégicos e Internacionais. $\mathrm{n}^{\circ} 3$, março/abril de 2007, p. 4 Disponível em: <http://www.ieei.pt/files/070326 boletim_versao2.pdf $>$. Acesso em: 3 dez. 2008.

${ }^{248}$ O Benelux é a união de três países, cada um deles representado por parte do nome em apreço: Bélgica (BE), Holanda (NE) e Luxemburgo (LUX).
} 
economia nacional, a criação de um mercado comum e a harmonização progressiva das políticas sociais.

A seguir, o grande destaque foi o Tratado de Roma, em que se definiram regras que ensejaram significativa cessão de parte da soberania dos Estados-Membros em favor da Comunidade, se bem que, desde a CECA, já era perceptível tal tendência. Contudo, a parcela de soberania alienada com a CECA foi significativamente menor do que àquela cedida no Tratado de Roma em favor da Comunidade ${ }^{249}$. O Tratado de Roma é a designação estabelecida para o conjunto formado por dois diferentes tratados: (i) o Tratado Constitutivo da Comunidade Econômica Européia (CEE); e (ii) o Tratado Constitutivo da Comunidade Européia de Energia Atômica (Euratom). Foram, ambos, assinados em 25 de março de 1957, em Roma, pela Alemanha, França, Itália, Bélgica, Holanda e Luxemburgo, entrando em vigor em $1^{\circ}$ de janeiro de 1958.

O Tratado Constitutivo da Comunidade Européia de Energia Atômica (Euratom) buscou criar condições de desenvolvimento de uma indústria nuclear. Obteve sucesso e não sofreu alterações relevantes até hoje, período no qual continua em vigor. A Euratom manteve, desde sempre, personalidade jurídica distinta da União Européia, apesar de compartilhar com ela as mesmas instituições.

O Tratado Constitutivo da Comunidade Econômica Européia, por sua vez, estabeleceu uma união aduaneira entre os Estados-Membros, fixando, em seu art. $8^{\circ}$, um período de 12 anos para que os países se adaptassem às imposições nesse sentido determinadas, tais como promover o desaparecimento das barreiras alfandegárias entre os países partícipes. Além disso, criou uma política agrícola comum através de medidas protecionistas frente a produtos oriundos de países não pertencentes ao bloco e estabelecendo a livre circulação de produtos agrícolas dentro da Comunidade Econômica Européia. Também proibiu monopólios, concedeu benefícios às regiões periféricas da CEE e estabeleceu políticas comuns na área dos transportes.

A maior fluidez dos intercâmbios comerciais proporcionada pelo Tratado gerou um impulso em direção à integração, levando a que, em $1^{\circ}$ de julho de 1968, se suprimissem todos os entraves internos entre os Estados-Membros. Vale ressaltar que este mercado comum buscava somente a livre circulação de mercadorias, pessoas, capitais e

249 LECH, Marcelo; MOREIRA, Luiz Carlos. A Política Externa e de Segurança Comum da União Européia. Canoas: Editora da ULBRA, 2004, p. 13. 
serviços, além de desenvolvimento de políticas comuns nessas áreas e na de transporte, no que obteve sucesso.

A CEE criou diversas instituições supranacionais, que deveriam paulatinamente aumentar em poder no decorrer do processo de integração. São elas: (i) a Comissão Européia; (ii) o Conselho Europeu; (iii) o Parlamento Europeu; (iv) o Tribunal de Justiça da União Européia; e (v) o Comitê Econômico e Social Europeu.

Assim se criaram as bases para que, através de uma progressiva integração econômica se atingisse uma união política. Nesse sentido, o preâmbulo do Tratado que instituía a CEE:

\footnotetext{
- Determinados a estabelecer os fundamentos de uma união cada vez mais estreita entre os povos europeus;

- Decididos a assegurar, mediante uma ação comum, o progresso econômico e social dos seus países eliminando as barreiras que dividem a Europa;

- Fixando como objetivo essencial dos seus esforços a melhoria constante das condições de vida e de trabalho dos seus povos;

- Reconhecendo que a eliminação dos obstáculos existentes requer uma ação concertada tendo em vista garantir a estabilidade na expansão econômica, o equilíbrio nas trocas comerciais e a lealdade na concorrência;

- Preocupados em reforçar a unidade das suas economias e assegurar o seu desenvolvimento harmonioso pela redução das desigualdades entre as diversas regiões e do atraso das menos favorecidas; - Desejosos de contribuir, mercê de uma política comercial comum, para a supressão progressiva das restrições ao comércio internacional; - Pretendendo confirmar a solidariedade que liga a Europa e os países ultramarinos e desejando assegurar o desenvolvimento da prosperidade destes, em conformidade com os princípios da Carta das Nações Unidas;

- Resolvidos a consolidar (...) a defesa da paz e da liberdade e apelando para os outros povos da Europa que partilham dos seus ideais para que se associem aos seus esforços (...)
}

Também nesse sentido, seu art. $2^{\mathrm{o}}$ :

A Comunidade tem como missão, através da criação de um mercado comum e da aproximação progressiva das políticas dos EstadosMembros, promover, em toda a Comunidade, um desenvolvimento harmonioso das atividades econômicas, uma expansão contínua e equilibrada, uma maior estabilidade, um rápido aumento do nível de vida e relações mais estreitas entre os Estados que a integram.

Quanto ao aspecto institucional, o equilíbrio passou a assentar no tripé composto pelo Conselho, pela Comissão e pelo Parlamento Europeu. Conforme o sítio oficial da 
União Européia, "O primeiro elabora as normas, a segunda apresenta propostas e o Parlamento tem um papel consultivo. Acessoriamente, intervém no processo de decisão um outro órgão consultivo, o Comitê Econômico e Social" ${ }^{\text {250. }}$.

A Comissão, independente dos governos e nomeada de comum acordo, zela pelo interesse comum, o que faz pelo campo legislativo. Detém o monopólio da iniciativa legislativa, propõe atos comunitários ao Conselho de Ministros e defende a obediência aos tratados, sendo, para isso conferidos a ela diferentes instrumentos de controle dos EstadosMembros e das empresas.

O Conselho de Ministros é composto por representantes dos governos dos Estados-Membros e detém o poder de decisão. O Comitê de Representantes Permanentes (COREPER), órgão auxiliar ao Conselho, executa-as. Já o Parlamento “só dispunha de poder de emitir pareceres e os seus membros ainda não eram eleitos por sufrágio direto e universal" ${ }^{251}$. Já se previu também, no tratado, a criação de um Tribunal de Justiça comum.

Importante assinalar, neste particular, que foram vários os tratados posteriores que vieram para alterar o constitutivo da CEE até a promulgação do Tratado de Maastricht, a partir do qual analisaremos esse processo de integração no decorrer desta pesquisa. Entre esses tratados podemos destacar os seguintes ${ }^{252}$ :

\section{(i) Tratado de Bruxelas, denominado "Tratado de Fusão" (1965)}

Assinado em 8 de abril de 1965, entrou em vigor em $1^{\circ}$ de julho de 1967. Substitui os três Conselhos de Ministros (CEE, CECA e Euratom), de um lado, e as duas Comissões (CEE, Euratom) e a Alta Autoridade (CECA), de outro, por um Conselho único e uma Comissão única. Para além desta fusão administrativa, verifica-se o estabelecimento de um orçamento de funcionamento único.

\section{(ii) Tratado que altera algumas disposições orçamentais (1970)}

Assinado em 22 de abril de 1970, entrou em vigor em $1^{\text {o }}$ de janeiro de 1971.

Substitui o sistema de financiamento das Comunidades por contribuições dos

\footnotetext{
250 Actividades da União Européia: síntese da lesgislação. A construção européia através dos tratados: Tratado que institui a Comunidade Económica Europeia ou CEE. Disponível em: $<$ http://europa.eu/scadplus/treaties/eec pt.htm>. Acesso em: 19 jan. 2008.

${ }^{251}$ Idem.

252 Ibidem.
} 
Estados-Membros pelo sistema dos recursos próprios. Institui igualmente um orçamento único para as Comunidades.

\section{(iii) Tratado que altera algumas disposições financeiras (1975)}

Assinado em 22 de julho de 1975, entrou em vigor em $1^{\circ}$ de junho de 1977. Confere ao Parlamento Europeu o direito de rejeitar o orçamento e de dar quitação à Comissão no que respeita à sua execução. Institui igualmente um Tribunal de Contas único para as três Comunidades, que constitui um organismo de controle contabilístico e de gestão financeira.

\section{(iv) Ato Único Europeu (1986)}

Assinado em 28 de fevereiro de 1986, entrou em vigor em $1^{\circ}$ de julho de 1987. Constitui a primeira grande reforma dos Tratados. Permite o alargamento dos casos de votação por maioria qualificada no Conselho, o reforço do papel do Parlamento Europeu (procedimento de cooperação) e o alargamento das competências comunitárias. Introduz o objetivo de realização do mercado interno até 1992.

Embora já mencionado anteriormente, deve ser ressaltado, uma vez mais, que, desde a constituição da CECA, se percebe, nitidamente, a cessão de parcela significativa da soberania nacional em favor da Comunidade. Contudo, como também foi afirmado, a parcela de soberania alienada, no âmbito da CECA, foi significativamente menor do que aquela cedida no Tratado de Roma ${ }^{253}$.

Foi dentro desse espírito de integração e cooperação, como se viu, que alguns países cederam parte de sua soberania, o que não fizeram sem, antes, estabelecerem metodologias para que aqueles países, para os quais seria mais difícil a adoção das medidas acordadas, também pudessem se adequar às imposições comunitárias. Surgiu aí o conceito de 'diferenciação'. Sobre esse tema, CUNHA afirma:

O conceito de diferenciação foi primeiramente acolhido na lei primária das comunidades no Single European Act, em consideração ao objetivo da criação do mercado interno: o novo artigo 8-C do Tratado de Roma

${ }^{253}$ LECH, Marcelo; MOREIRA, Luiz Carlos. Op. cit., p. 13. 
estatuiu que devida consideração deveria ser dada pela Comissão, ao apresentar suas propostas, para o esforço de que as medidas propostas deveriam representar para certas economias que não estavam no mesmo nível de desenvolvimento.

Esta é a visão tradicional ou clássica de 'diferenciação', que abrange a concordância de todos os Estados-Membros no que concerne aos objetivos comuns, e à consideração de que alguns deles, ainda não preparados para sustentar o ritmo dos outros, podem ter temporariamente o benefício de uma derrogação.

O mesmo conceito de diferenciação, correspondendo a uma idéia de "Europa de duas velocidades ou multi-velocidades", está na base do precedente inserido no Tratado de Roma pelo Tratado da União Européia em relação à participação no terceiro estágio da união econômica e monetária. Apenas aqueles estados que preencham as condições necessárias para a adoção da moeda comum serão admitidos àquele estágio. O restante aguardará até que seja confirmado que eles alcançaram os critérios de convergência ${ }^{254}$. (Tradução livre)

Dessa forma, com o Tratado de Roma foram estabelecidas regras e procedimentos importantes para melhoras na integração político-econômica entre os Estados-Membros, tais como a cessão de prazos maiores para adequação econômico-monetária dos países com dificuldades nesse âmbito, impedindo-os de ampliarem sua integração em relação ao bloco caso não cumpridas as exigências impostas pelo Tratado e pela Comissão Européia daí instaurada. Havendo interesse dos países, na maior parte, no incremento das relações econômicas, desenvolveu-se sistema de estímulo-resposta adequado o suficiente para incentivá-los a cumprirem com as metas propostas, e maleável na medida correta para pesar a realidade e dificuldades político-econômicas de Estado partícipe específico, a fim de lhe proporcionar prazo maior para adaptação e posterior avanço a um estágio de integração superior.

VERÇOSA, sobre os fins desde sempre almejados com o longo processo de integração europeu, pelos países participantes, assim escreve:

\footnotetext{
${ }^{254}$ The concept of differentiation was first received in the primary communities law in the Single European Act, in regard to the objective of the creation of the internal market: the new article 8-C of the Treaty of Rome stated that due consideration should be given by the Commission, on presenting its proposals, to the effort that the proposed measures would represent to certain economies which were not at the same level of development. This is the classic or traditional view of "differentiation", which involves the agreement of all Member-States in regard to the common objectives, and the consideration that some of them, not yet prepared to sustain the rhythm of the others, may have temporarily the benefit of a derrogation. The same concept of differentiation, corresponding to the idea of "two-speed or multy-speed Europe", is on the basis of the precedent inserted in the Treaty of Rome by the Treaty on European Union in regard to the participation in the third stage of economic and monetary union. Only those States which fulfill the necessary conditions for the adoption of the common currency shall be entitled to enter that stage. The remainder will wait until it is confirmed that they have achieved the convergence criteria. CUNHA, Paulo de Pitta e. Monetary Union and Differentiation. The External Dimension. Revista da Faculdade de Direito da Universidade de Lisboa, Coimbra Editora, Coimbra, 1997, p. 113.
} 
O objetivo final, como resultado do estabelecimento da união, conforme já examinado, depois de percorrido o processo intermediário, viria a ser a supressão dos controles nacionais no campo do câmbio, a liberalização dos movimentos de capitais no seio dos Países-membros, na convergência das políticas econômicas, na criação do instituto monetário europeu, culminando no estabelecimento de um sistema europeu de bancos centrais, tendo como órgão de cúpula o banco central europeu, responsável pela emissão de uma moeda única, o euro, cuja vida já se iniciou, sendo este o período do seu crescimento e fortalecimento ${ }^{255}$.

Após o Ato Único Europeu, de 1986, o próximo passo importante foi dado através do Tratado de Maastricht, a partir do qual se cria, dentre outras instituições, a União Econômica e Monetária. Assim, a primeira lição que extraímos desse panorama histórico é que a União Econômica e Monetária só foi possível graças a um processo laborioso, longo e claramente delineado, com um objetivo específico, estabelecido através de uma autêntica "carta de navegação" que definiu os pontos a serem atingidos e fixou as datas para a sua execução. Constata-se que nada foi improvisado ou decidido abruptamente no seio da União Européia. Assim, a União Econômica e Monetária representa a fase superior e final de um processo de integração econômica que teve início na década de 1950.

\section{2 - O Tratado de Maastricht e o Aprofundamento da Integração via União Européia}

A idéia principal dos fundadores da União Européia foi fortalecer a integração e a pacificação política da Europa. Houve, assim, uma vontade política muito forte nesse sentido.

O Tratado de Maastricht, também conhecido por Tratado da União Européia, assinado, na Holanda, em 7 de fevereiro de 1992, entrou em vigor no dia $1^{\circ}$ de novembro de 1993, consagrando a nova União Européia (UE) com a aprovação e a implantação de um mercado interno único, a instituição de um Banco Central e um sistema financeiro e bancário comum, com moeda própria, o euro, que entrou em circulação no início de $1999^{256}$.

\footnotetext{
${ }^{255}$ VERÇOSA, Haroldo Malheiros Duclerc. Op. cit., p. 471.

${ }^{256}$ RIBEIRO, Maria de Fátima. O Euro e as perspectivas de implantação de uma moeda única no Mercosul. Revista de Direito Constitucional e Internacional, vol. 31. São Paulo: Revista dos Tribunais, 2000, p. 12.
} 
Também ficou garantida a cidadania única aos habitantes dos Estados-Membros. $\mathrm{O}$ acordo lançou, ainda, as bases de uma política externa e de defesa européia. Na questão social, foram definidos quatro direitos básicos dos cidadãos da União Européia: livrecirculação, igualdade entre homens e mulheres, assistência previdenciária e melhores condições de trabalho. Além disso, procedeu-se à unificação da legislação trabalhista, criminal, de imigração e das políticas externas dos Estados-Membros"257.

Em resumo, o Tratado de Maastricht, in verbis:

Congrega numa só entidade, a União Européia, as três Comunidades (Euratom, CECA, CEE) e as cooperações políticas institucionalizadas nos domínios da política externa, da defesa, da polícia e da justiça. A CEE passa a designar-se por CE. Além disso, este tratado cria a União Econômica e Monetária, institui novas políticas comunitárias (educação, cultura) e alarga as competências do Parlamento Europeu (procedimento de co-decisão) $)^{258}$.

A decisão de adotar a moeda única constitui parte integrante do Tratado da União Européia. Nesse sentido é a redação do art. $2^{\circ}$ do tratado, in verbis:

Artigo $2^{\circ}$ A União atribui-se os seguintes objetivos: A promoção do progresso econômico e social e de um elevado nível de emprego e a realização de um desenvolvimento equilibrado e sustentável, nomeadamente mediante a criação de um espaço sem fronteiras internas, o reforço da coesão econômica e social e o estabelecimento de uma união econômica e monetária, que incluirá, a prazo, a adoção de uma moeda única, de acordo com as disposições do presente Tratado;

Sobre as vantagens de um política monetária comum, como a que foi determinada foi pelo Tratado de Maastricht e posteriormente implantada em solo europeu, afirma RIBEIRO:

Os principais benefícios da união monetária podem ser destacados com o aumento da credibilidade da política monetária e redução da inflação interna, eliminando a incerteza cambial; com isso, diminuirão as resistências das indústrias domésticas à integração nacional e à redução dos custos de transação e de conversão de moedas ${ }^{259}$.

${ }^{257}$ GAROFALO FILHO (2004). Op. cit., p. 260.

258 Actividades da União Européia: síntese da lesgislação. A construção européia através dos tratados: Tratado que institui a Comunidade Económica Europeia ou CEE. Disponível em: $<$ http://europa.eu/scadplus/treaties/eec pt.htm>. Acesso em: 19 jan. 2008.

${ }^{259}$ RIBEIRO, Maria de Fátima. Op. cit., p. 11. 
Do mesmo modo, VERÇOSA disserta sobre a União Européia:

(...) a concepção de uma moeda única teve o intuito, justamente, de evitar as grandes flutuações cambiais que freqüentemente têm ocorrido entre os países participantes da União Européia, do que resulta sempre rápida e volumosa movimentação de capitais atrás de lucros imediatos, disso surgindo efeitos perniciosos diversos para a economia em geral ${ }^{260}$.

No Conselho Europeu de Madri, ocorrido em dezembro de 1995, os chefes de Estado e de Governo dos então quinze Estados-Membros decidiram designar por "euro" a moeda única e delinearam um cenário definitivo para a sua introdução.

Nessa linha, a Comissão Européia submeteu à consideração do Conselho Europeu $^{261}$, órgão máximo de decisão política da União, o Informe e Recomendação sobre o Progresso para a Convergência com vistas à Transição para a Terceira Fase da União Econômica e Monetária ${ }^{262}$. O Informe indicava que onze Estados-Membros da União Européia estavam aptos para aderir à moeda única a partir de $1^{\circ}$ de janeiro de 1999 , a saber: Alemanha, Bélgica, Espanha, França, Irlanda, Itália, Luxemburgo, Holanda, Portugal, Áustria e Finlândia.

Cada Estado-Membro teve que respeitar todos os critérios de convergência para poder participar na terceira fase da União Econômica e Monetária (UEM). Os critérios foram especificados no "Protocolo ( $\left.n^{\circ} 21\right)$ relativo aos critérios de convergência a que se refere o artigo $121 .^{\circ}$ do Tratado que institui a União Européia, in verbis:

\section{Artigo 121. ${ }^{\circ}$}

1. A Comissão e o IME apresentarão relatórios ao Conselho sobre os progressos alcançados pelos Estados-Membros no cumprimento das suas obrigações relativas à realização da União Económica e Monetária. Esses relatórios devem conter um estudo da compatibilidade da legislação nacional de cada Estado-Membro, incluindo os estatutos do seu banco central nacional, com o disposto nos artigos $108 .^{\circ}$ e $109 .^{\circ}$ do presente Tratado e nos Estatutos do SEBC. Os relatórios analisarão igualmente a realização de um elevado grau de convergência sustentada,

\footnotetext{
${ }^{260}$ VERÇOSA, Haroldo Malheiros Duclerc. Op. cit., p. 473.

261 “(...) cabe diferenciar o Conselho, enquanto órgão da Comunidade Européia, do Conselho Europeu, composto por Chefes de Estado e de Governo e pelo Presidente da Comissão, ao qual cabe, conforme art. $4^{\circ}$ do Tratado da União Européia, a função de guia” que dá os 'impulsos necessários’ para o desenvolvimento da União. O 'Conselho Europeu' deve ser distinguido do 'Conselho', pois no cumprimento das atribuições do Conselho Europeu expressas no art. $4^{\circ}$ do Tratado da União Européia não se trata de atos do Conselho, tampouco de uma forma de 'empréstimo de órgão' para o segundo e terceiro pilares." AMBOS, Kai; PEREIRA, Ana Cristina. Mercosul e união européia: perspectivas da integração regional. Rio de Janeiro: Lúmen Juris, 2004, p. 24.

${ }^{262}$ Em 25 de março de 1998.
} 
com base na observância, por cada Estado-Membro, dos seguintes critérios:

— a realização de um elevado grau de estabilidade dos preços, que será expresso por uma taxa de inflação que esteja próxima da taxa, no máximo, dos três Estados-Membros com melhores resultados em termos de estabilidade dos preços,

- a sustentabilidade das suas finanças públicas, que será traduzida pelo facto de ter alcançado uma situação orçamental sem défice excessivo, determinado nos termos do $n^{\circ} 6$ do artigo $104^{\circ}$,

- a observância, durante pelo menos dois anos, das margens normais de flutuação previstas no mecanismo de taxas de câmbio do Sistema Monetário Europeu, sem ter procedido a uma desvalorização em relação à moeda de qualquer outro Estado-Membro,

- o carácter duradouro da convergência alcançada pelo Estado-Membro e da sua participação no mecanismo de taxas de câmbio do Sistema Monetário Europeu deve igualmente reflectir-se nos níveis das taxas de juro a longo prazo.

Os quatro critérios a que se refere o presente número e os respectivos períodos durante os quais devem ser respeitados vêm desenvolvidos num Protocolo anexo ao presente Tratado. Os relatórios da Comissão e do IME devem ter, de igual modo, em conta o desenvolvimento do ECU, os resultados da integração dos mercados, o nível e a evolução da balança de transacções correntes e a análise de evolução dos custos unitários de trabalho e de outros índices de preços. (...). ${ }^{263}$

Conforme aponta RIBEIRO, o objetivo desse pacto, com todas as suas exigências, foi dar ao euro status de moeda forte, capaz de competir com o dólar estadunidense e o iene japonês no mercado internacional ${ }^{264}$.

Cabe observar que a Grécia, a Dinamarca, o Reino Unido e a Suécia não aderiram ao euro imediatamente à época de implementação da Terceira Fase da União Econômica e Monetária, mas por razões diversas.

Apenas a Grécia, como veremos logo a seguir, não apresentou as condições macroeconômicas exigidas, em que pese desejasse desde logo aderir ao euro. O Reino Unido, a Suécia (esta, com as observações a serem feitas, também, mais à frente) e a Dinamarca optaram por não participar da união monetária ${ }^{265}$.

A Dinamarca e o Reino Unido notificaram o Conselho de que não participariam da terceira fase da União Econômica e Monetária. Assim, quando das negociações do tratado de Maastricht, tais Estados obtiveram cláusula de opt-out ${ }^{266}$. A previsão legal da

\footnotetext{
${ }^{263}$ Numeração dos artigos em ordinais, de acordo com o texto original da norma legal.

${ }^{264}$ RIBEIRO, Maria de Fátima. Op. cit., p. 13.

${ }^{265}$ TRICHES, Divanildo. Economia Política do Mercosul e aspectos monetários, cambiais e o Euro em perspectiva. Caxias do Sul: Educs, 2003, p. 75.

${ }_{266}$ Introdução do euro: critérios de convergência. 20/06/2006 Disponível em: <http://www.europa.eu $>$.
} 
opção de Reino Unido e Dinamarca de manterem suas moedas originais encontra-se nos respectivos protocolos $\mathrm{n}^{\text {os }} 25^{267}$ e $26^{268}$ anexos ao Tratado de Maastricht.

Levando em consideração que os Estados-Membros Grécia e Suécia não preencheram (o primeira, por fragilidade interna, e o segundo, por opção), à época, as condições necessárias para a adoção da moeda única (critérios de convergência) ${ }^{269}$, tais países foram objeto de uma derrogação, procedimento já explicado em momento anterior e previsto no artigo $122^{\circ}$ do Tratado.

Cabe esclarecer que a Grécia não preencheu os critérios de convergência quanto aos seguintes aspectos:

- taxa média de inflação de 5,2 \%, nível superior ao valor de referência;

- foi objeto de uma decisão do Conselho sobre a existência de um déficit orçamentário excessivo;

- não havia participado no mecanismo de taxas de câmbio durante os dois anos anteriores e a "dracma" grega esteve sujeita a tensões combatidas através de um aumento das taxas de juro e por intervenções no mercado cambial;

- taxas de juro de longo prazo, em média, de 9,8\%, nível superior ao valor de referência.

Acesso em: 29 nov. 2008.

${ }^{267}$ A cláusula de exceção prevista no Protocolo $\left(\mathrm{n}^{\circ} 25\right)$ Relativo a Certas Disposições Relacionadas com o Reino Unido da Grã-Bretanha e Irlanda do Norte (1992) dispõe, basicamente que: "El protocolo estipula que determinados artículos del Tratado no son aplicables al Reino Unido: los poderes del Reino Unido en el ámbito de la política monetaria no son modificados por el Tratado (el Reino Unido conserva los poderes en el ámbito de la política monetaria según el derecho nacional); el Reino Unido no está sometido a las disposiciones del Tratado relativas a los déficits excesivos; al Reino Unido no le atañen las disposiciones del Tratado sobre el Sistema Europeo de Bancos Centrales (SEBC), el Banco Central Europeo (BCE) y los reglamentos y decisiones de estas instituciones. Los derechos de voto del Reino Unido se suspenden para los actos del Consejo relativos a: la decisión sobre la fijación irrevocable de los tipos de cambio entre las monedas de los Estados miembros que pasan a la tercera fase y al euro; el nombramiento del Presidente, del Vicepresidente y de los cuatro miembros restantes del Comité de Dirección del BCE. Para ello los votos ponderados del Reino Unido se excluyen de cualquier cálculo a efectos de una mayoría cualificada." Reino Unido: cláusula de exención de la UEM 30.6.2006. Disponível em: <http://www.europa.eu>. Acesso em: 29 nov. 2008.

${ }^{268}$ A cláusula de exceção prevista no Protocolo $\left(\mathrm{n}^{\circ} \mathrm{XX}\right)$ Relativo a Certas Disposições Relativas à Dinamarca, anexo ao Tratado Constitutivo da Comunidade Européia (1992) aborda basicamente que: "el Gobierno danés notificará al Consejo su posición relativa a la participación en la tercera fase antes de que el Consejo haga su evaluación de los criterios de convergencia; en caso de que Dinamarca notificara que no participa en la tercera fase, Dinamarca disfrutará de una excepción, lo que significa que serán aplicables todas las obligaciones del Tratado y el estatuto del Sistema Europeo de Bancos Centrales (SEBC) que hacen referencia a una excepción; el procedimiento para poner fin a la excepción sólo se iniciará a petición de Dinamarca." Dinamarca: cláusula de exención de la UEM. 16.8.2006. Disponível em: $<$ http://www.europa.eu>. Acesso em: 29 nov. 2008.

${ }^{269}$ Decisión 98/317/CE. 
No caso da Suécia, há controvérsias, pois, apesar de ter optado por não aderir ao euro, pode-se constatar que o país não preencheu os critérios de convergência relativamente aos seguintes pontos:

- sua legislação apresentava incompatibilidade com os artigos $108^{\circ}$ e $109^{\circ}$ do Tratado e com os estatutos do Sistema Europeu de Bancos Centrais (SEBC).

- nunca participou no mecanismo de taxas de câmbio e, durante os dois anos anteriores, a coroa sueca flutuou em relação às moedas do mecanismo de taxas de câmbio.

A adesão da Grécia ao euro ocorreu somente em $1^{\circ}$ de janeiro de 2001, nos termos da decisão do Conselho, de 19 de junho de 2000, em conformidade com a disposição do $\mathrm{n}^{\mathrm{o}}$ 2 do artigo $122^{\circ}$ do Tratado de Maastricht.

\section{3 - Etapas e Cronograma da Implantação do Euro}

A construção do euro envolveu historicamente três etapas principais ${ }^{270}$ :

A primeira delas caracterizou-se por reformas preliminares e início da convergência ( $1^{\text {o }}$ de julho de 1990 - 31 de dezembro de 1993), que envolveram total liberdade de circulação de capitais na UE (supressão dos controles cambiais), aumento dos recursos destinados a corrigir desequilíbrios entre regiões européias (fundos estruturais) e convergência econômica, (através da supervisão multilateral das políticas econômicas dos Estados-Membros) $)^{271}$.

Já a segunda fase evidenciou-se pela preparação dos Estados-Membros à UEM ( $1^{\circ}$ de janeiro de 1994 - 31 de dezembro de 1998), o que envolveu a criação do Instituto Monetário Europeu (IME) em Frankfurt, composto pelos governadores dos bancos centrais dos países da União, a independência dos bancos centrais nacionais e a regulamentação sobre a redução dos déficits orçamentários ${ }^{272}$. Pode-se afirmar que o IME foi precursor do Banco Central Europeu (BCE). Em 1997, o Conselho Europeu de Amsterdã aprovou o Pacto de Estabilidade e Crescimento e criou o MTC II, sucessor do Sistema Monetário Europeu e do MTC após o lançamento do euro ${ }^{273}$. Em 1998, foram selecionados (em

\footnotetext{
${ }^{270}$ Aspectos Práticos da Introdução do Euro. Disponível em: < $\underline{\text { http://europa.eu/scadplus/leg/pt/s01001.htm> }}$. Acesso em: 2 dez. 2008.

${ }^{271}$ A União Econômica e Monetária (UEM) e o Euro. In: A União Européia em 12 Lições. Disponível em: $<$ http://europa.eu/abc/12lessons/lesson_7/index_pt.htm>. Acesso em: 2 dez. 2008.

${ }^{272}$ A União Econômica e Monetária (UEM) e o Euro. Op. cit.

273 EU4JOURNALISTS - Direção Geral de Comunicação da Comissão da União Européia. A União
} 
decorrência do cumprimento dos critérios de convergência) os onze Estados-Membros que adotariam o euro no ano de 1999.

Entre as funções ${ }^{274}$ do IME estavam a supervisão do sistema monetário europeu; reforçar a coordenação das políticas monetárias dos Estados-Membros, com o objetivo de garantir a estabilidade dos preços; proceder a consultas sobre questões da competência dos bancos centrais nacionais, que afetem a estabilidade das instituições e mercados financeiros; assumir as atribuições do Fundo Europeu de Cooperação Monetária, que viria a substituir, por dissolução daquele; promover a utilização do euro e supervisionar a sua evolução, incluindo o bom funcionamento do respectivo sistema de compensação; preparar os instrumentos e procedimentos necessários à execução de uma política monetária única; promover, sempre que necessário, a harmonização das normas e práticas que regulam o levantamento, a organização e a divulgação de estatísticas no domínio de suas atribuições; preparar as normas para as operações a serem realizadas pelos bancos centrais nacionais no quadro do sistema europeu de bancos centrais; promover a eficácia dos pagamentos transacionais; e supervisionar a preparação técnica das notas de banco emitidas em euros.

Sobre sua estrutura, assim se manifesta VERÇOSA:

(...) entidade dotada de personalidade jurídica, administrada por um conselho composto por um presidente e pelos governadores dos bancos centrais nacionais, um dos quais na condição de seu vice-presidente, escolhido pelo conselho do instituto. O presidente, por sua vez, deverá ser nomeado, de comum acordo, pelos governos dos Estados-membros, para tanto representados pelos seus respectivos chefes de governo ou de Estado, sob recomendação do comitê de governadores dos bancos centrais dos Estados-membros, após consulta ao Parlamento Europeu e ao Conselho. O presidente do Instituto deverá ser escolhido entre pessoas de reconhecida competência e com experiência profissional nos domínios monetário ou bancário (art. 109-F, n. 1). O instituto teria o papel de órgão precursor do banco central europeu (arts. 109-F, ns. 8 e 9 e $9^{\circ}$, do Protocolo n. 4).

O presidente será nomeado por um período de três anos, com exercício em regime de tempo integral, a não ser quanto a casos excepcionais, conforme derrogação concedida pelo conselho do instituto (art. $9^{\circ}$ ns. 3 e 4 do Protocolo n. 4).

O instituto terá como membros os bancos centrais nacionais (art. $1^{\circ}$, n. 2 , do Protocolo n. 4). Seu comitê dos governadores foi concebido para

Económica e Monetária e o Euro. Disponível em: $<\underline{\mathrm{http}: / / \text { www.eu4journalists.eu/ }}$ index.php/dossiers/portuguese/C23 >. Acesso em: 3 dez. 2008.

${ }^{274}$ Arts. $109^{\circ}-\mathrm{F}, \mathrm{n}^{\circ} 2$ e $4^{\circ}$ do Protocolo n 4 e art. $109^{\circ}-\mathrm{F}, \mathrm{n}^{\circ} 3$. 
funcionar até o início da segunda fase da implementação da Comunidade Européia, ocasião em que se daria a sua dissolução (art. 109-F, n. 2). Essa dissolução veio a dar-se pelo artigo $1^{\circ}$, n. 3 , do Protocolo n. 4 do Tratado da União Européia.

Sua dissolução foi prevista para a ocasião no início do funcionamento do banco central europeu, para o qual deverão ser transferidas todos os seus ativos e responsabilidades (art. 23 do Protocolo n. 4).

$\mathrm{O}$ instituto era dotado de personalidade jurídica e de patrimônio próprios, devendo o seu conselho fixar o montante dos recursos financeiros que deverão formar este último (arts. 14 e 16 do Protocolo n. 4). ${ }^{275}$

Por fim, ainda na segunda etapa de implementação do euro, vale destacar que houve a criação do BCE, com a missão de dirigir a política monetária da União Européia e fiscalizar as atividades do Sistema Europeu de Bancos Centrais ${ }^{276}$.

Por fim, na terceira fase ocorreu a organização e aplicação da UEM (a partir de $1^{\circ}$ de janeiro de 1999), em que 11 Estados adotaram o euro na forma não-material, com as taxas de câmbio das moedas fixadas pelo seu valor do último dia de $1998^{277}$. O euro passou, assim, a ser a moeda comum da Áustria, da Bélgica, da Finlândia, da França, da Alemanha, da Irlanda, da Itália, do Luxemburgo, da Holanda, de Portugal e da Espanha (aos quais se juntou a Grécia em 1 de janeiro de 2001). A partir desse momento, o Banco Central Europeu substituiu o IME e passou a ser responsável pela política monetária, que é definida e executada em |euros. Em $1^{\circ}$ de janeiro de 2002, entraram em circulação nos 12 Estados-Membros da área do euro as notas e moedas de euros. Dois meses depois, as notas e moedas nacionais tinham sido retiradas. A partir daí, só o euro passou a ter curso legal nos Estados-Membros da área do euro, que representam mais de dois terços da população da União Européia ${ }^{278}$.

A criação da união monetária prevista no Tratado de Maastricht, para a qual houve o estabelecimento de entidades supranacionais, a fim de possibilitar a consecução das políticas monetárias comuns, deve ser encarada tendo em vista o período histórico no qual se insere a prolatação do referido tratado. Além de ser fruto de uma longa e planejada evolução, iniciada nos anos 50, como já anteriormente explanado, precisa-se entender que se vivia, à época, o fim da Guerra Fria.

\footnotetext{
${ }^{275}$ VERÇOSA, Haroldo Malheiros Duclerc. Op. cit., p. 466.

276 TRICHES, Divanildo. Op. cit., p. 80.

${ }^{277}$ EU4JOURNALISTS. Op. cit.

${ }^{278}$ Idem.
} 
Neste cenário, em 1989 a Alemanha se unifica. CUNHA informa que, então:

\begin{abstract}
A França, no período após a unificação da Alemanha, estava ansiosa para submeter o poder monetário de seu vizinho sob a autoridade de instituições supranacionais. A Alemanha, que já estava gozando de soberania monetária 'de facto', não iria desistir de sua moeda nacional sem ser assegurada de que as instituições monetárias européias iriam seguir o modelo alemão - um banco central independente dos governos e outras instituições da União e tendo como objetivo primário a luta contra a inflação ${ }^{279}$.
\end{abstract}

Além disso, houve, desde o início da Comunidade Européia:

(...) uma preocupação com a condução da política econômica dos Estados-membros, que deveria contribuir para a realização dos objetivos maiores daquela, ou seja, $\left(\right.$ art. $102 \mathrm{c} / \mathrm{c}$ o $\left.2^{\circ}\right)$ :

a) promover

- o desenvolvimento harmonioso e equilibrado das atividades econômicas;

- o crescimento sustentável e não inflacionista, respeitado o meio ambiente;

- um alto grau de convergência dos comportamentos das economias;

- um elevado nível de emprego e de proteção social;

- o aumento do nível e da qualidade de vida;

- a coesão econômica e social; e - a solidariedade dos Estadosmembros;

- atuar de acordo com o princípio de uma economia de mercado aberto e de livre concorrência; e

- favorecer uma repartição eficaz dos recursos ${ }^{280}$.

Somados os fatores, e feitos os devidos preparos em relação ao anteriormente explicado IME, instituiu-se um Sistema Europeu de Bancos Centrais (SEBC) e um Banco Central Europeu (BCE) em que todos os bancos centrais, inclusive o europeu, são autônomos. Regula-se, em específico, a autonomia do Banco Central Europeu através do art. 107 (e pelo art. $7^{\circ}$ do Protocolo $n^{\circ} 3$ ).

Assim, com o Tratado de Maastricht e com os protocolos a ele seguidos, o BCE e o Banco Central de cada Estado-Membro ficaram impedidos de, até mesmo, "solicitar ou

\footnotetext{
${ }^{279}$ France, in the aftermath of the unification of Germany, was anxious to subsume the monetary power of its neighbour under the authority of supranational institutions. Germany, who was already enjoying 'de facto' monetary sovereignity, was not about to give up its national currency without being assured that the European monetary institutions would follow the German model - a central bank independent from the governments and the other institutions of the Union and having as primary objective the fight against inflation. CUNHA, Paulo de Pitta e. Op. cit., p. 116.

${ }^{280}$ VERÇOSA, Haroldo Malheiros Duclerc. Op. cit., p. 454-455.
} 
receber instruções das instituições ou organismos comunitários, dos governos dos Estados-membros ou de qualquer outra entidade"281, devendo a legislação dos EstadosMembros adaptar-se a essas exigências até a implantação do novo sistema econômicomonetário (art. 108), o que pode ser compreendido pela forte influência que a Alemanha exerceu durante o processo de integração.

O SEBC é, basicamente, um sistema de regras que abarca os bancos centrais nacionais e o Banco Central Europeu, daí o porquê de seu nome. Busca a estabilidade dos preços, devendo, ainda, apoiar as políticas econômicas gerais na comunidade, tendo em vista contribuir para a realização de seus objetivos (arts. 105, n. 1 e $2^{\circ}$ do Protocolo do Tratado de Maastricht).

Tem como funções ${ }^{282}$ : definir e executar a política monetária da comunidade; realizar as operações cambiais; gerir, na qualidade de depositário, as reservas cambiais oficiais dos Estados-Membros; promover o bom funcionamento do sistema de pagamentos; contribuir para a boa condução das políticas desenvolvidas pelas autoridades competentes, no que se refere à supervisão prudencial das instituições de crédito e a estabilidade do sistema financeiro; e autorizar, com exclusividade, a emissão de notas de banco na comunidade, as quais podem ser emitidas pelo próprio Banco Central Europeu e pelos bancos centrais nacionais, e que serão as únicas com curso legal na comunidade.

Sua direção cabe aos órgãos de decisão do Banco Central Europeu, correspondentes ao Conselho deste órgão e à Comissão Executiva, e sua transparência (accountability) é garantida pelo envio anual de relatório sobre as atividades do sistema e sobre a política monetária do ano anterior e do ano em curso ao Parlamento, Comissão e Conselho europeus. O Banco Central Europeu, hierarquicamente superior no sistema, como entidade supranacional que é, deve enviar, ao menos trimestralmente, "relatórios sobre as atividades do sistema de bancos centrais. Semanalmente, ainda, deverá publicará uma informação sobre a situação financeira consolidada do sistema",283

O BCE é pessoa jurídica que goza "da mais ampla capacidade jurídica reconhecida às pessoas coletivas pelas legislações nacionais, podendo adquirir ou alienar bens de quaisquer espécies e estar em juízo (arts. 106, n. 2 e $9^{\circ}$, n. 1, do

\footnotetext{
${ }^{281}$ Ibidem, p. 456.

${ }^{282}$ Arts. 105 , ns. 2 e 5 e $105-\mathrm{A}$; art. $3^{\circ}$ do Protocolo.

${ }^{283}$ VERÇOSA, Haroldo Malheiros Duclerc. Op. cit., p. 459.
} 
Protocolo)"284. Seus órgãos de decisão são o conselho, a comissão executiva e o conselho geral (arts. 106, n. 3 e 10-1 e 45 do Protocolo).

O BCE desempenha, ainda, as seguintes atividades: apoiar os bancos centrais nacionais; contribuir em benefício do desempenho de funções consultivas desses mesmos bancos; colaborar na compilação de informações estatísticas; dar parecer sobre qualquer proposta de ato comunitário dentro de suas atribuições; e idem, quanto às autoridades nacionais, instituições ou organismos comunitários, sobre qualquer projeto de disposição legal no campo de suas atribuições.

Sobre as operações externas efetuadas pelo BCE, assim explica VERÇOSA:

As operações externas à comunidade poderão ser praticadas pelo banco central e pelos bancos centrais nacionais, quanto a bancos centrais e instituições financeiras de terceiros países, bem como com relação a organizações internacionais. Nesse campo inclui-se a compra e venda de todos os tipos de ativos cambiais e de metais preciosos e de operações bancárias em geral $^{285}$.

Cabe também, por fim, ao BCE, definir princípios gerais para as operações de mercado aberto e de crédito e realizá-las, por si próprio ou pelos bancos centrais nacionais. Ficou, pois, com a implantação do BCE, garantida a união monetária e a implantação do euro. Entidade supranacional, preza por sua autonomia, assim como pela de todos os outros bancos centrais. Com a instituição do SEBC, do BCE e, conseqüentemente, do euro, atingiu-se, no âmbito dos países que cumpriram as imposições comunitárias, o terceiro grau de integração já há tanto tempo almejado pelo processo integracionista europeu.

Em relação à cronologia de implementação do euro, cumpre destacar os seguintes fatos:

- em 1969, na reunião de cúpula de Haia, os seis países-membros da Comunidade Econômica Européia (CEE) estabelecem como objetivo a União Econômica e Monetária (Plano Barre);

- em 1971, o Plano Werner propõe uma convergência das economias nacionais com vistas a dotar a CEE de uma moeda única. A instabilidade das moedas européias faz com que o projeto seja deixado de lado por um tempo;

\footnotetext{
${ }^{284}$ Ibidem, p. 460.

${ }^{285}$ Ibidem, p. 462.
} 
- em 1972, é instaurado um controle da flutuação das moedas européias, com a criação da serpente monetária européia e, em 1979, com o sistema monetário europeu (SME);

- em 1986, o Ato Único inscreve no Tratado de Roma o objetivo da realização progressiva de uma União Econômica e Monetária (UEM);

- em 1990, tem-se a primeira etapa da UEM, com a livre circulação de capitais;

- em 1992, o Tratado de Maastricht define os critérios de convergência entre as economias dos países participantes, etapa prévia para a moeda única;

- em 2 de maio de 1998, o Conselho Europeu estabelece a lista dos países participantes: Alemanha, Áustria, Bélgica, Espanha, Finlândia, França, Irlanda, Itália, Luxemburgo, Holanda e Portugal (adesão da Grécia em 2001);

- em $1^{\circ}$ de junho de 1998, ocorre a criação do Banco Central Europeu (BCE), encarregado da política monetária européia;

- em $1^{\circ}$ de janeiro de 1999, o euro torna-se a moeda única. A taxa de conversão entre o euro e as moedas nacionais) é estabelecida de maneira irrevogável. As transações nos mercados de capitais passam a ser feitas em euros;

- em $1^{\circ}$ de janeiro de 2002, o euro entra definitivamente em vigor em 12 EstadosMembros (área do euro) da União Européia, e torna-se a moeda única de 300 milhões de europeus.

BITTENCOURT ${ }^{286}$ constata, nesse diapasão, que o euro, a partir de $1^{\circ}$ de janeiro de 2002, deixou de ser virtual para tornar-se realidade: três anos depois de ter sido introduzido no mercado financeiro, na condição de moeda abstrata, o euro chegou, finalmente, ao bolso dos consumidores, circulando em 12 Estados-Membros da União Européia.

\section{4 - O Euro x Experiências Anteriores}

Não é a primeira vez que acontece uma união monetária na história mundial, mas o euro é, sem dúvida, a mais importante e ambiciosa delas, sendo que se trata, também, de uma experiência ainda em curso,e, certamente, inacabada.

${ }^{286}$ BITTENCOURT, Silvia. O Euro. São Paulo: Publifolha, 2002. 
A Europa já havia vivido, nos séculos passados, várias uniões monetárias ${ }^{287}$, a destacar:

- a primeira que se tem notícia ocorreu durante o Império Romano ${ }^{288}$, em que nos seus primeiros anos, a nobreza de Roma tomou das novas regiões ocupadas pagamento para suas necessidades. O propósito da conquista foi subsidiar Roma e não os novos territórios conquistados. Os benefícios da introdução de uma moeda única foram bem entendidos pelos comerciantes do mundo antigo. A moeda local foi substituída pela moeda romana onde vigia a Lei Romana ${ }^{289}$. Desse modo, essas moedas oferecem uma visão única da antiga vida romana, porque eram usadas diariamente por todos, do imperador ao mais simples cidadão de Roma ou de alguma Província e Colônia do Império. A expansão romana provocou transformações na economia e com a integração de novos territórios ao Império passou a existir um crescimento progressivo do comércio, havendo um intenso tráfego comercial entre as várias regiões abarcadas pelo poderio romano. Depois do séc. III a.C., a principal atividade econômica dos romanos passou a ser o comércio. O Império Romano, assim, além da unidade centralizada de governo, possuía uma unidade econômica $^{290}$, com apenas uma moeda em circulação ${ }^{291}$;

\footnotetext{
287 "Historically, whenever there has been a superpower in the world, the currency of the superpower plays a central role in the international monetary system. This has been as true for the Babylonian shekel, the Persian daric, the Greek tetradrachma, the Macedonian stater, the Roman denarius, the Islamic dinar, the Italian ducat, the Spanish doubloon and the French livre as it has for the more familiar pounds sterling of the $19^{\text {th }}$ century and the dollar of the 20th century. The superpower typically has a veto over the international monetary system and because it benefits from the international use of its currency, its interest is usually in vetoing any kind of global collaboration that would replace its own currency with an independent international currency." MUNDELL, Robert. The international monetary system in the 21st century: could gold make a comeback? Lecture delivered at St. Vincent College, Letrobe, Pennsylvania, March 12, 1997, p.4.

288 "Neste sentido, conceituamos o Império Romano como uma entidade política centralizada, fundamentada numa estrutura celular e concêntrica, cujo poder hegemônico era exercido através de relações de troca de poder e riqueza entre o centro, áreas integradas, semi-periferias e periferias, cuja existência foi criada e reproduzida historicamente numa dinâmica de exploração, de integração, de interação e de diversidade cultural.” MENDES, Norma Musco. Império e Romanização: 'Estratégias', Dominação e Colapso. Brathair 7 (1), 2007, p. 30. Disponível em: <http://www.brathair.com>. Acesso em: 2 dez. 2008.

${ }^{289}$ EU Watch. A Short History of Single Currencies. A Publication of The Independence/Democracy Group. Issue 3, Oct./Nov. 2006, p 21.

${ }^{290}$ Importante mencionar que o nome da moeda colonial romana, portanto, de cerca de dois milênios atrás, chamava-se "VICTORIATUS". Cf. MENDES, Antonio; NASCIMENTO, Edson Bueno. Estudo de Direito Monetário: a moeda e suas funções; obrigações monetárias; estipulação e indexação de obrigações monetárias. Revista da Procuradoria Geral do Estado de São Paulo, São Paulo, jun. 1991, p.83.

291 "Certainly the Romans controlled the main roads and placed fortified trading stations along them. Trade existed throughout the entire period between this region and the Roman merchants (probably from Aquileia), and as was established by F. Cassola, Romanization was a gradual process, where cultural and economic factors preceded military and administrative ones. (Cassola 1983, 35)." MISKEC, Alenka. The early romanization of the southeastern alpine region in the light of numismatic fins. Arheoloski vestnik (Asc. vest), 54, 2003, p. 373.
} 
- em seguida, tivemos a União Monetária Latina, constituída em 1865 pela França, Bélgica, Suíça e Itália. Em 1866, a Grécia e a Romênia tornaram-se membros. Os EstadosMembros acordaram em cunhar as suas moedas com a mesma padronização e em limitar a sua cunhagem. Moedas em conformidade com os padrões definidos seriam aceitas como legais pelas repartições governamentais em todos os Estados-Membros. A União Monetária Latina perdurou até o início da I Guerra Mundial (1914) ${ }^{292}$. O relativo sucesso da União Monetária Latina influenciou a adoção de uma moeda única além do território dos seis Estados-Membros. Nesse sentido, realizou-se a Conferência Monetária Internacional de 1867 visando estabelecer um padrão monetário único para toda a Europa. As idéias práticas da conferência fracassaram, e nenhuma mudança monetária seguiu à conferência;

- finalmente, a União Monetária Escandinava, datada de 1870, formada pela Suécia, Dinamarca e Noruega através da assinatura em Estocolmo de uma convenção, adotando uma moeda comum, a "krona", baseava-se no ouro. Visou-se com a união que todos os Estados participantes produzissem as moedas com a mesma espessura, ainda que mantivessem a imagem diferente em cada uma delas. A ascensão da União Monetária Escandinava resultou da falha do projeto Parieu e da oposição francesa ao padrão ouro. $\mathrm{O}$ fracasso da União Monetária Escandinava foi determinado pela perda de uma âncora nominal, além de pela pressão inflacionária que seguiu-se ao início da I Guerra Mundial ${ }^{293}$. A União Monetária Escandinava alcançou um grau de integração superior ao da União Monetária Latina e durou até $1924^{294}$.

A introdução do euro busca, desde o início, representar uma profunda transformação histórica. Iniciada a partir da integração promovida na década de 1950, a criação da moeda única européia torna-se agora realidade em um contexto diplomático e econômico bem definido, mas longe ainda de se mostrar consolidado, conquanto construído e alicerçado em premissas muito específicas e não reproduzíveis noutros contextos locais.

\footnotetext{
${ }^{292}$ EU Watch. Op. cit., p. 21.

${ }^{293}$ RAZGALLAH, Brahim. Was the Scandinavian monetary union an optimum currency area? A generalised purchasing-power parity approach p. 2. Disponível em: < http://www.soc.uoc.gr/macro/11 conf/ docs/paper_SMU_razgallah.pdf $>$. Acesso em: 3 dez. 2008.

${ }^{294}$ Uma moeda para a Europa: o caminho para o Euro. Luxemburgo, Serviço de Publicações Européias, 2007, p. 1. Disponível em: <http://ec.europa.eu/economy_finance/publications/publication6730_pt.pdf>. Acesso em: 2 dez. 2008.
} 
Como é sabido, as transformações no cenário internacional tiveram início, no século XX, com o fim da URSS ${ }^{295}$. O euro surgiu como divisa internacional, ao lado do dólar dos Estados Unidos, em uma urgência da Europa em se consolidar como potência política economicamente unificada e geográfica e historicamente bem posicionada. Esse cenário internacional busca, pois, beneficiar não só a própria Europa, mas, notadamente, os países em desenvolvimento como o Brasil, que pelo regime democrático poderá encontrar novas perspectivas, diferentes das traçadas desde a hegemonia norte-americana. $\mathrm{O}$ euro pretende ser um paradigma que se opõe, assim, ao imperialismo norte-americano, mas que, a nosso ver, mormente em face de suas próprias imperfeições estruturais em sua criação e implementação, poderá fracassar nesse seu desiderato.

\section{5 - Resistências e Dificuldades na Implantação do Euro}

A União Européia, estabelecida pelo Tratado de Maastricht, tem mais de 500 milhões de habitantes - a terceira maior população do mundo, após a China e a Índia. O produto interno bruto (PIB) da União Européia - ou seja, a produção de bens e serviços está a aumentar de forma constante. Desde a adesão de novos Estados-Membros em 2004, o PIB da UE é superior ao dos Estados Unidos. Embora a UE represente apenas 7\% da população mundial, o seu comércio com o resto do mundo corresponde a cerca de um quinto do volume global de exportações e importações ${ }^{296}$. No entanto, apesar desses números, o processo de implantação do bloco sofreu algumas dificuldades, em especial no que concerne à implantação da União Política e Monetária.

O euro é uma experiência inédita, talvez a mais ousada da história econômica dos povos. Nunca uma união monetária reunira tantos Estados e, ademais, é decorrência não de uma crise econômica, mas de um processo sistematizado (e pacífico) de integração da Europa $^{297}$.

Deve-se refutar, inicialmente, toda e qualquer tentativa de reduzir o euro (e o processo que representa) a uma mera reforma monetária. No caso atual da Europa, está-se diante de uma união monetária, em que as moedas nacionais dos Estados-Membros foram

\footnotetext{
${ }^{295}$ Em 25 de dezembro de 1991 tem fim a URSS, fazendo surgir 15 novos países.

${ }^{296}$ Informações obtidas em "Fatos e Números Essenciais sobre a Europa e os Europeus". Disponível em: $<$ http://www.europa.eu>. Acesso em: 2 dez. 2008.

${ }^{297}$ PINHO, Diva Benevides. Euro versus Dólar... E o Real? São Paulo: Informações Fipe, n 221, 1999, p. 16.
} 
simplesmente convertidas em euros, não pressupondo perdas no poder de compra, nos salários nem nas economias dos cidadãos, a exemplo do que ocorre com uma reforma monetária, conquanto, na prática, não tenha havido paridade no poder de compra dos Estados-membros. É imprescindível entender a singularidade da União Econômica e Monetária da União Européia ${ }^{298}$.

Ao entendê-la, não se deve confundi-la com meras reformas monetárias, tampouco equipará-la a outras tentativas de união monetária eventualmente realizadas no passado. A UEM é uma unificação monetária, com controle centralizado da oferta de dinheiro no nível da União. Ela decorre de um contexto de profunda integração financeira entre um grupo de Estados. A UEM implica o respeito a um conjunto de regras conhecidas através do Pacto de Estabilidade e Crescimento, conjunto de regras concebidas para garantir a solidez das finanças públicas dos Estados-Membros, sendo um fator importantíssimo para assegurar um crescimento sustentável dos envolvidos.

O euro é resultado de um longo processo de integração política e econômica da Europa que superou, inclusive, crises provocadas, entre outros fatores, pelas políticas divergentes dos países europeus e por uma opinião pública insegura.

O euro contou com entusiastas e opositores (os últimos sendo principalmente economistas). Estes consideravam as economias européias heterogêneas demais para adotarem uma moeda única e alertavam para o fato de esta ter sido introduzida sem a existência de um poder central. Os chamados "eurocéticos" custos relacionados ao projeto: a introdução do euro exigiu, por exemplo, a conversão de milhões de máquinas automáticas do continente e a eliminação de toneladas de notas e moedas antigas, que, em parte, acabaram como sucata ${ }^{300}$.

Por fim, a opinião pública européia sentiu-se alheia às decisões que levaram à introdução do euro, alegando, em várias pesquisas, desconhecimento sobre a nova moeda única e suas conseqüências.

A despeito das dificuldades anteriormente expostas, cumpre defender que o euro não é uma moeda sem alma, mas simplesmente jovem ${ }^{301}$.

\footnotetext{
298 EICHENGREEN, Barry. Are there parallels between EMU and similar historical experiences? 14 January 2008. Disponível em: $<$ http://www.voxeu.org/index.php?q=node/869>. Acesso em: 2 dez. 2008.

299 Encontra-se "eurocéticos", por exemplo, tanto em deputados "de direita" quanto "de esquerda" do Parlamento Europeu.

300 "Saiba por que o Euro foi criado e como foi a maior troca monetária da história". Folha de São Paulo. 14 de setembro de 2008. Disponível em: <http://www1.folha.uol.com.br/folha/publifolha/ ult10037u351840.shtml>. Acesso em: 4 dez. 2008.

${ }^{301}$ Cf. declarações tiradas de uma coletânea de textos de escritores europeus, na qual eles se despedem de
} 
Visando enfrentar as dificuldades surgidas e contribuir para a harmonização e plena implementação do euro, é que foram fixados os requisitos de convergência macroeconômica (abordado, anteriormente, no subcapítulo 4.2) e decidida a "carta de navegação" da moeda única tecnicamente. Já em relação à sustentabilidade ou permanência no tempo dos compromissos de convergência e coordenação econômica adquiridos pelos Estados-Membros, o Conselho Europeu de Amsterdã, em junho de 1997, adotou o "Pacto de Estabilidade e Crescimento", obrigando juridicamente os EstadosMembros a manter, perenemente, os mesmos requisitos de convergência contidos no Tratado de Maastricht, fixando penas pecuniárias em relação àqueles que não cumprissem o acordado.

Sobre o Tratado de Amsterdã, assinado em 2 de outubro de 1997 e que entrou em vigor em $1^{\text {o }}$ de maio de 1999 , assim resume o órgão oficial da União Européia:

(...) permite alargar as competências da União mediante a criação de uma política comunitária de emprego, a comunitarização de uma parte das matérias que eram anteriormente da competência da cooperação no domínio da justiça e dos assuntos internos, as medidas destinadas a aproximar a União dos seus cidadãos e a possibilidade de formas de cooperação mais estreitas entre alguns Estados-Membros (cooperações reforçadas). Alarga, por outro lado, o procedimento de co-decisão, bem como a votação por maioria qualificada, e procede à simplificação e a uma nova numeração dos artigos dos Tratados ${ }^{302}$.

O Pacto de Estabilidade e Crescimento daí surgido assenta-se em dois aspectos essenciais: um sistema preventivo para identificar e corrigir as derrapagens orçamentais antes de se atingir o limiar de 3\% do PIB previsto no Tratado da UE, e um conjunto de normas de dissuasão para pressionar os Estados-Membros a evitar os déficits excessivos e a adotar as medidas necessárias para a sua rápida correção.

O Pacto contém três elementos juridicamente vinculativos:

$\checkmark$ uma resolução do Conselho Europeu ${ }^{303}$ consagrando o compromisso dos Estados-Membros, da Comissão e do Conselho de pôr em prática o pacto,

suas antigas moedas nacionais: Uwe Wittstock (Hrg.), Ade, Ihr Schönen Scheine - Europäische Schriftsteller Nehmen Abschied von Ihren Währungen. München: Deutscher Taschenbuch Verlag, 2001, p. 23 e 57.

${ }^{302}$ Actividades da União Européia: síntese da lesgislação. A construção européia através dos tratados:

Tratado que institui a Comunidade Económica Europeia ou CEE. Disponível em: < http://europa.eu/scadplus/treaties/eec pt.htm>. Acesso em: 19 jan. 2008.

${ }^{303}$ RESOLUÇÃO DO CONSELHO EUROPEU sobre o Pacto de Estabilidade e Crescimento Amsterdã, 17 de Junho de 1997 (97/C 236/01). 
bem como o compromisso dos Estados-Membros com o objetivo de conseguir orçamentos equilibrados, ou mesmo excedentários;

$\checkmark$ um regulamento do Conselho sobre o reforço do controle da situação orçamental e do controle e coordenação das políticas econômicas, que implica que os Estados-Membros participantes transmitirão os respectivos planos de estabilização, com objetivos orçamentais nacionais a médio prazo e outras informações pertinentes;

$\checkmark$ um regulamento do Conselho ${ }^{304}$ relativo à aceleração e transparência da aplicação do procedimento relativo aos déficits excessivos que prevê, em última instância a imposição de sanções.

As sanções a que um Estado-Membro está sujeito caso não corrija o déficit excessivo tal como recomendado pelo Conselho são:

- efetuar um depósito, com limite máximo para o montante anual de $0,5 \%$ do PIB do Estado-Membro, sem juros (provavelmente associado a outras sanções não pecuniárias previstas no Tratado);

- transformação do depósito em multa.

Nesse sentido, é interessante transcrever os arts. $7^{\circ}, 11,12$ e 13 do Regulamento (CE) n ${ }^{o} 1467 / 97$ do Conselho:

Artigo $7^{\mathbf{0}}$ Se os Estados-membros participantes não cumprirem as
sucessivas decisões do Conselho nos termos dos $\mathrm{n}^{\text {os }} 7$ e 9 do artigo $104^{\circ}$ -
$\mathrm{C}$, a decisão do Conselho de impor sanções, nos termos do $\mathrm{n}^{\circ} 11$ do
artigo $104^{\circ}-\mathrm{C}$, será tomada no prazo de dez meses a contar das datas de
notificação previstas no Regulamento $(\mathrm{CE}) \mathrm{n}^{\circ} 3605 / 93$, tal como referido
no $\mathrm{n}^{\mathrm{o}} 3$ do artigo $3^{\circ}$ do presente regulamento. Recorrer-se-á a um
procedimento acelerado no caso de um défice programado de forma
deliberada e que o Conselho decida ser excessivo.

Artigo $\mathbf{1 1}^{\circ}$ - Sempre que o Conselho decidir aplicar sanções a um Estado-membro participante por força do $\mathrm{n}^{\circ} 11$ do artigo $104^{\circ}-\mathrm{C}$, será exigida, regra geral, a constituição de um depósito não remunerado.

O Conselho pode decidir complementar este depósito através das medidas previstas nos primeiro e segundo travessões do $\mathrm{n}^{\circ} 11$ do artigo $104^{\circ} \mathrm{C}$.

\section{Artigo 12}

${ }^{304}$ Regulamento (CE) no 1467/97 do Conselho de 7 de Julho de 1997 relativo à aceleração e clarificação da aplicação do procedimento relativo aos défices excessivos. Jornal Oficial n 1, L 209 de 02/08/1997, p. 6-11. 
1. Quando o défice excessivo resultar do não cumprimento do critério relativo à relação do défice orçamental referida no $n^{\circ} 2$, alínea a), do artigo $104^{\circ}-\mathrm{C}$, o montante do primeiro depósito incluirá uma componente fixa, correspondente a $0,2 \%$ do PIB, e uma componente variável correspondente a um décimo da diferença entre o défice expresso em percentagem do PIB no ano anterior e os $3 \%$ do valor de referência do PIB.

2. Em cada um dos anos seguintes, e até que a decisão sobre a existência de um défice excessivo seja revogada, o Conselho avaliará se o Estadomembro participante em causa tomou medidas efectivas em resposta à notificação do Conselho nos termos do $\mathrm{n}^{0} 9$ do artigo 104-C. Nessa avaliação anual, o Conselho decidirá, nos termos do ${ }^{\circ} 11$ do artigo $104^{\circ}$ $\mathrm{C}$ e sem prejuízo do disposto no artigo $13^{\circ}$ do presente regulamento, intensificar as sanções, a não ser que o Estado membro participante em causa tenha cumprido o estabelecido na notificação do Conselho. $\mathrm{O}$ montante do depósito adicional deverá ser igual a um décimo da diferença entre o déficit expresso como percentagem do PIB no ano anterior e os $3 \%$ do valor de referência do PIB.

3. Qualquer dos depósitos a que se referem os $n^{\text {os }} 1$ e 2 não deverá exceder o limite máximo de $0,5 \%$ do PIB.

Artigo $1^{\mathbf{0}}$ - O depósito será, regra geral, convertido numa multa pelo Conselho, nos termos do $\mathrm{n}^{\circ} 11$ do artigo $104^{\circ}-\mathrm{C}$, se, dois anos após a data da decisão de impor ao Estado-membro participante a constituição de um depósito, o Conselho considerar que o défice excessivo não foi corrigido.

Os novos Estados-Membros da União Européia que ainda não aderiram ao Euro encontram-se sob um regime "probatório" de estabilização das taxas de câmbio.

Muita polêmica na literatura foi criada no que tange à taxa de câmbio no período de transição, de sua fixação irrevogável em relação ao Euro e na substituição das moedas nacionais $^{305}$. Parte da doutrina ${ }^{306}$ afirmou que o sistema de taxa de câmbio, baseado no compromisso de paridade central multilateral ou bilateral, tornava-se vulnerável a ataques especulativos, devido à liberalização plena do fluxo de capitais. Além disso, choques assimétricos de demanda em alguns Estados não poderiam ser ajustados sem a utilização de desvalorização cambial como instrumento de política econômica para estimular as

\footnotetext{
${ }^{305}$ Vale destacar os seguintes nomes e respectivas obras: GOODHART, Charles. The approach to EMU. Making EMU happen problems and proposals: a symposium. New Jersey: International Finance Sector, Princeton University, p. 30-39, Aug. 1996 (Essay in International Finance no 199); GROS, Daniel. Linking the ins and outs. Making EMU happen problems and proposals: a symposium. New Jersey: International Finance Section, (Essay in International Finance $n^{\circ}$ 199), Princeton University, p. 40-49. Aug. 1996.; SPAVENTA, Luigi. Coexisting with the euro: prospects and risks after Verona. Making EMU happen problems and proposals: a symposium. New Jersey: International Finance Section, (Essay in International Finance $\mathrm{n}^{\circ}$ 199), Princeton University, p. 50-63. Aug. 1996; WYPLOSZ, Charles. EMU: Why and how it might happen. Journal of Economic Perspectives, Nashville: American Economic Association, vol. 11, $\mathrm{n}^{\mathrm{o}}$ 04, p. 03-22, fall 1997.

${ }^{306}$ Nesse sentido: SPAVENTA, Luigi. Op. cit., e SALVATORE, Dominick. The common unresolved problem with the EMS and EMU. American Economic Review Nashville: American Economic Association, vol. 86, $\mathrm{n}^{\circ}$ 02, may 1997, p. 224-226. (Papers and Proceedings).
} 
exportações, nem reduzir as taxas de juros para estimular a demanda doméstica. Tais situações poderiam levar a uma crise do sistema monetário. Ainda com as eventuais dificuldades que possam surgir durante o período de transição cambial, os EstadosMembros ainda não adeptos do Euro em sua plenitude, e interessados nisso, tentam adequar-se e superar as dificuldades do período de transição.

Dos dez novos Estados-Membros que aderiram à UE em $1^{\circ}$ de maio de 2004, a Eslovênia foi o primeiro a conseguir sua adesão à moeda única. Este país participou, desde 28 de junho de 2004, no mecanismo de taxas de câmbio europeu (MTC II), percebendo-se que o dólar esloveno ${ }^{307}$ não sofreu tensões graves até $1^{\circ}$ de janeiro de 2007 , data em que o Estado aderiu completamente ao euro ${ }^{308}$.

Ainda que existam dificuldades na implementação e adoção do euro, os progressos em matéria de convergência macroeconômica têm sido notáveis. Exemplo disso é que a média dos déficits fiscais do setor público dos Estados-Membros havia caído de 6,1\% em 1993, para 2,4\% em 1997 e a média da inflação tinha baixado substancialmente para menos de $2 \%$ naquele último ano.

Os resultados positivos no seio da União Européia contribuíram para o avanço em direção à moeda única na data prevista, bem como no fomento do comércio e da inversão de investimentos em patamar global, num ambiente de maior estabilidade macroeconômica, maior crescimento e menor inflação. Constatamos, em face do exposto, que a implementação do "euro" está intimamente relacionada com a coesão que deve existir entre os países constitutivos da União Européia.

A área do euro ${ }^{309}$ ainda não pode ser considerada uma "área monetária ótima"310, em razão da limitada mobilidade da mão-de-obra; rigidez nos mercados de trabalho;

\footnotetext{
307 O Tolar foi a moeda oficial da Eslovênia entre Outubro de 1991 e Dezembro de $\underline{2006}$, tendo sido substituído pelo Euro. O tolar era dividido em cem stotins.

${ }^{308}$ Adesão da Eslovênia ao Euro (2007). Disponível em: < $<$ http://europa.eu/scadplus/leg/pt/lvb/125085.htm>. Acesso em: 2 dez. 2008.

309 "A expressão 'área do euro' designa o conjunto dos países que possuem a moeda única. O termo "Eurolândia" ou qualquer outro termo não deve ser utilizado em português." Código de Redação

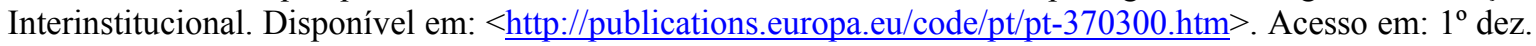
2008.

310 "As áreas monetárias ótimas têm sido caracterizadas como um grupo de regiões ou países com uma relativa homogeneidade econômica, em que ocorre uma perfeita ou quase perfeita mobilidade de bens e serviços e de fatores produtivos. A migração de mão-de-obra dentro da área deve ser suficientemente alta. Essa é uma condição para que seja mantido o pleno emprego, o que, em última análise, significa tornar os choques assimétricos entre regiões sem efeito maior. Os fluxos de capital também devem ter elevada mobilidade entre os países, fluindo para as regiões mais atrativas economicamente, até que a taxa de retorno seja equalizada. Dentro desse ponto de vista, as áreas monetárias ótimas constituem-se numa integração total dos mercados de bens e serviços, e dos mercados de capitais ou financeiros (...)." TRICHES, Divanildo. $O p$. cit., p. 41-42.
} 
diferenças institucionais; e inexistência de um sistema federal de transferências de renda entre países. A união monetária determinou a esses a perda dos instrumentos da taxa de câmbio e juros (um custo limitado pela falta de eficácia da política monetária para corrigir qualquer problema estrutural). Ainda hoje, constata-se nos países certa assimetria dos ciclos econômicos. 


\section{CAPÍTULO V}

ANÁLISE DA POSSIBILIDADE DE ADOÇÃO DE UMA MOEDA ÚNICA NO MERCOSUL

\section{1 - Histórico}

A “integração monetária” é objetivo antigo dos Estados atualmente integrantes do Mercosul, mas atualmente tem sido pauta política no Brasil, inclusive e no Mercosul, em particular. As raízes da abordagem do tema remontam aos acordos firmados no âmbito da Associação Latino Americana de Livre Comércio (ALALC). Apesar das décadas de prática dessa abordagem do tema (a partir da década de 1960, com maior ou menor intensidade, dependendo do momento em especial a ser focado no passado), na prática pouco se avançou. No entanto, a recorrência do debate torna imperiosa uma análise mais acurada do assunto, a partir do histórico já traçado. As medidas até agora tomadas restringem-se a meras "trocas de informações" e tentativas de administração de crises e o próprio Mercosul, como se sabe, parece imerso em permanente crise sistêmica.

O tema da coordenação de políticas macroeconômicas entre os atuais Estados Partes do Mercosul tem estado presente nas reuniões dos negociadores de tais entidades políticas desde a origem do processo de integração (na época, apenas entre Brasil e Argentina). Nesse sentido assinou-se em 1985 a Ata de Iguaçu, que formalizou o Programa de Integração e Cooperação Econômica Brasil-Argentina, bem como o Tratado Bilateral de Integração e Cooperação Econômica de 1988. A temática em análise foi, inclusive, objeto de um dos primeiros protocolos assinados pelos presidentes Sarney e Alfonsín.

Em 1986, no Protocolo n ${ }^{\mathrm{o}} 10$ de Estudos Econômicos ${ }^{311}$, objetivou-se facilitar medidas que tendessem a harmonizar as políticas econômicas dos dois países. Posteriormente, em 1987, através do Protocolo $n^{\circ} 20^{312}$, definiu-se a necessidade de se iniciar um processo visando à criação de uma unidade monetária comum (o gaúcho) que deveria ser emitida e respaldada por um Fundo de Reserva Binacional. Tal fundo estaria

\footnotetext{
${ }^{311}$ Buenos Aires, 29 jul. 1986.

${ }^{312}$ Viedma, 17 jul. 1987.
} 
ancorado nos recursos derivados do Convênio de Pagamentos e Créditos Recíprocos (CCR), por meio da ampliação gradual dos prazos de compensação das transações comerciais. Todavia, tal proposta, elaborada pela comissão brasileira não teve apoio e foi descartada.

É interessante destacar que Brasil e Argentina sofreram durante todo o processo integracionista desenvolvido no século passado com problemas de inflação ${ }^{313}$, em maior ou menor medida, dependendo da época, fator que, por si só, já solaparia o projeto em questão. Tal problema de controle de inflação, associado à notória dificuldade de entendimento entre os dois maiores países partes do Mercosul, resultou em que as iniciativas em favor da coordenação monetária não prosperassem devido à ausência de incentivos de cada país para um entendimento em torno de uma agenda bastante vaga. A unificação monetária, para ser implementada, envolveria compromissos maiores do que aqueles até então assumidos, ou com possibilidade iminente de serem assumidos por Brasil e Argentina, visando à intensificação dos esforços pró-coordenação.

Além dos protocolos $n^{\text {os }} 10$ e 20 supramencionados, merece destaque o Acordo de Cooperação Mútua entre os Bancos Nacionais dos países integrantes do Mercosul - o BANASUR, firmado em 11 de novembro de 1994 entre o Banco da República Oriental do Uruguai, Banco Nacional de Fomento (Paraguai), Banco do Brasil e o Banco da Nação Argentina, tendo como objetivos a concessão de financiamentos que facilitassem o incremento das relações de câmbio e de comércio exterior; promoção de intercâmbio de empregados ligados à área de processamento de dados e comércio exterior; promoção do comércio dentro do Mercosul, entre outros ${ }^{314}$.

Posteriormente, em 15 de dezembro de 1995, no desenrolar do processo integracionista, a partir do Protocolo de Ouro Preto (POP), o Mercosul passou a ter personalidade jurídica de direito internacional, podendo negociar como bloco com outros países e outros blocos ou organismos internacionais. Logo a seguir, em 1998, na mesma esteira, os presidentes da Argentina, Brasil, Paraguai, Uruguai, e dos membros associados do Mercosul, durante a XIV Reunião do Conselho do Mercado Comum, assinaram, em Ushuaia, na Argentina, documento que prevê a criação da moeda única do Mercosul, não definindo data para implantação de tal medida, dada sua natureza política.

\footnotetext{
${ }^{313} \mathrm{O}$ caso brasileiro é melhor explicitado no capítulo III do presente estudo, ao abordar os planos econômicos brasileiros.

314 MONTEIRO, Rogério. O Sistema Financeiro do Mercosul: Mercosur - Lições do período de transitoriedade. São Paulo: Celso Bastos, 1998, p. 157.
} 
Paralelamente a esse evento, conforme aponta RIBEIRO ${ }^{315}$, os ministros de Economia e presidentes do Banco Central de cada Estado Parte concordaram em se reunir periodicamente para coordenação de políticas macroeconômicas entre os países do bloco. Alguns entraves aí surgidos, no entanto, ainda se encontram pendentes de negociação, entre eles a definição dos critérios de convergência macroeconômica, a moeda a ser escolhida, a sede e a direção do Banco Central unificado e, ainda, a forma como a nova instituição tomará as decisões.

A inspiração para o aprofundamento da integração monetária entre os Estados da região do Cone Sul é, mais uma vez, proveniente do exemplo integracionista ocorrido em território europeu. A inspiração é anterior ao euro, sendo decorrente da implementação da União Européia de Pagamentos (UEP) ${ }^{316}$.

A UEP funcionou como âncora de desenvolvimento comercial intenso entre os países europeus ocidentais no pós-guerra, entre 1950 e 1958. A UEP viabilizou o comércio regional numa ampla escala, favorecendo o sistema produtivo e abrindo caminho para o projeto de integração regional que seguiu até a atualidade.

Merece atenção, ainda anterior à União Européia, a experiência européia do Acordo Monetário Europeu. Trata-se do trabalho de vários Estados, a partir de 1958, em prol de uma política de valorização de suas moedas. Tal empenho resultou no Acordo Monetário Europeu, criado em fins de 1958, para facilitar a liquidação dos balanços mensais dos bancos centrais dos Estados-Membros, com a possibilidade de concessão de crédito $^{317}$.

Deve-se mencionar, ainda, o êxito, em especial, da própria União Européia, exemplo maior do sucesso e realização de uma união monetária, através da União Econômica e Monetária que lhe é parte. Nesse sentido, as disposições do Tratado de Maastricht e seus Protocolos Anexos (particularmente aqueles relacionados com a moeda única, a exemplo dos já anteriormente mencionados protocolos $n^{\text {os }} 25$ e $26^{318}$ ) são a grande

\footnotetext{
${ }^{315}$ RIBEIRO, Maria de Fátima. Op. cit., p. 18.

316 "A UEP nasceu de um tratado assinado a 19 de setembro de 1950 , com efeitos retroativos até ao dia $1^{\circ}$ de julho anterior. No início, estava prevista para durar apenas dois anos, tendo sido prorrogada ano após ano." BARROS, José Fernando. Negociações para a criação de uma moeda única na união européia. In: MEDEIROS, Antonio (Org). O Ensino Jurídico no Limiar do Novo Século. Porto Alegre: EDIPUCRS, 1997, p. 260 .

317 BAUDHUIN, Fernando. Princípios de economia contemporânea. São Paulo: Difusão Européia do Livro, 1966, p. 270-272.

${ }^{318}$ Para maiores detalhes, ver o subcapítulo 4.2 do Capítulo IV do presente estudo.
} 
instrumentalidade jurídica que sustenta o movimento integracionista implementado até a atualidade.

As etapas sugeridas para a integração no âmbito do Mercosul se espelham, particularmente, na vitoriosa experiência da Europa Ocidental (alhures abordada no que tange à UEP). Nesse caso, primeiro houve o acordo de pagamentos, com a moeda contábil comum; depois, a integração da indústria básica, sobretudo carvão e aço; paralelamente, a especialização industrial, pela qual a Alemanha se tornou o grande supridor de bens de capital para o resto do bloco, ao mesmo tempo em que abria seu mercado para a produção de bens de consumo de seus parceiros; finalmente, como condição fundamental para o Tratado de Roma, que instituiu o mercado comum, ficou consagrado o princípio da uniformização das políticas sociais "por cima" - isto é, quem estivesse à frente estabeleceria o padrão para os demais. Dessa forma, o projeto de integração, que poderia ter-se confinado às elites econômicas e políticas européias, tornou-se efetivamente em integração em benefício dos povos da Europa Ocidental.

Existem, hoje, quatro áreas monetárias regionais no mundo, entendidas como blocos onde três ou mais países utilizam uma moeda comum: União Monetária Européia; Área Monetária do Leste do Caribe; União Monetária e Econômica do Oeste da África e Comunidade Econômica e Monetária Centro-Africana. Neste particular, HAWKINS e MASSON $^{319}$ assinalam as áreas monetárias regionais que existem ou já existiram no mundo.

Analisando as já existentes, os citados autores ${ }^{320}$ listam treze propostas, políticas e/ou acadêmicas, de áreas monetárias regionais e citam estudo de BAYOUMI e EICHENGREEN $^{321}$ que conclui pela inexistência de uma área monetária ótima nas Américas, segundo os critérios tradicionais da teoria de áreas monetárias ótimas. Por outro lado, ALESINA e BARRO ${ }^{322}$ dizem haver uma área para o dólar que vai do Canadá até partes da América do Sul.

Diante disso, entendemos que a adoção de uma moeda única pelos países do Mercosul é, a menos que se façam mudanças substanciais de ordem política, econômica e jurídica, uma impossibilidade real, o que se pode auferir de conjunto diversificado de

${ }^{319}$ HAWKINS, J.; MASSON, P. Regional Currency Areas and the use of Foreign Currencies. BIS paper, $\mathrm{n}^{\mathrm{o}}$ 17, maio 2003.

${ }^{320}$ Idem.

${ }^{321}$ BAYOUMI, T.; EICHENGREEN, B. One money or many? Analysing the prospects for monetary unification in various parts of the world. Princeton Studies in International Finance, $\mathrm{n}^{\mathrm{O}}$ 76, set. 1994.

${ }_{322}$ ALESINA, A.; BARRO, R.J. Dollarization. American Economic Review, vol. 91, no 2, maio 2001, p. 381-385. 
fatores e das condições que o bloco político-econômico apresenta atualmente. É devido a essa constatação que, antes mesmo de se pensar em união monetária, a integração monetária e financeira está de volta à agenda no Mercosul, sendo nesse sentido criados novos mecanismos de cooperação, tais como o Fundo Estrutural de Convergência (2006), o Banco do Sul (2007) e, principalmente, a possibilidade da utilização de pesos argentinos e reais brasileiros para a liquidação de transações internacionais, experiência esta que já está sendo adotada, via plano piloto, desde outubro de 2008, por meio do Sistema de Pagamentos em Moeda Local (SML), mas cujo volume é, pelos comentários disponíveis no mercado, muito incipientes e com grande probabilidade de vir a fracassar, a menos que medidas corretivas de grande magnitude venham a ser adotadas por Brasil e Argentina.

O histórico dos movimentos de integração no âmbito do Mercosul servem de base para que a o aprofundamento da integração no bloco seja pensado e eventualmente viabilizado mais do que por constrangimento externo (a exemplo do entendimento que se tinha da união monetária na união européia ser decorrente de constrangimento externo, tal como explicitado por TORRES ${ }^{323}$ ), por decisão autônoma e consistente visando à "maior integração" daqueles países que compõem o Mercosul.

É levando isso em conta que Fábio Giambiagi, do Banco Nacional de Desenvolvimento Econômico e Social (BNDES), recomenda que, para se alcançar uma convergência econômica nos países do Mercosul, seria interessante estabelecer metas mais rígidas do que as fixadas no caso dos países europeus. Ele sugeriu para 2006, por exemplo, que todos os países do Mercosul teriam de ter um déficit nominal máximo de 2,5\% do Produto Interno Bruto e a dívida pública não poderia representar mais de $40 \%$ do PIB. Paralelamente, para reforçar o compromisso com a unificação, haveria um teto inflacionário de $4 \%$, antes que a moeda se tornasse única, o qual ficaria reduzido para $3 \%$ depois $^{324}$, metas que não se cumpriram, como sabemos.

Mostra-se, pois, possível, na visão de Giambiagi, a implantação de moeda única no Mercosul a partir da adoção de conjunto de medidas rígidas que, para serem aplicadas, exigem compromisso sério com a integração por parte dos Estados envolvidos no processo.

No entanto, não se pode perder de foco que a unificação monetária apenas seria interessante de acordo com as relações buscadas entre os países, entre outros aspectos, no

323 TORRES, Francisco. Portugal towards economic and monetary union: a political economy perspective. In: JONES, Erik; FRIEDEN, Jeffry; TORRES, Francico. Joing Europe's Monetary Club: the challenges for Smaller member state. Nova Iorque: St. Martin's Press. 1998, p. 171-202.

${ }^{324}$ GIAMBIAGI, Fábio. Mercosul. O Estado de São Paulo, São Paulo, 2 de junho de 1997, p. B-12. 
que toca ao grau de integração comercial, à simetria dos ciclos econômicos, ao grau de mobilidade do trabalho e à convergência da inflação.

Outra discussão diz respeito à possibilidade jurídica, inclusive, hoje, de adoção da moeda única no Mercosul, à luz do sistema brasileiro. Já não se trata de aquilatar meras conveniências, mas de avaliar o próprio sistema normativo vigente e as potencialidades reais para implantação da moeda única, o que é objeto central da tese. No entanto, subjacente à linguagem normativa está a linguagem econômica, institucional e política, daí porque pensamos ser relevante abordar aspectos que dizem respeito à funcionalidade do sistema normativo brasileiro no tratamento da matéria.

\section{2 - A Possibilidade de uma Moeda Âncora e a Influência do Brasil no Mercosul}

Pode-se indagar se o Brasil poderia representar, no Mercosul, um papel semelhante ao desempenhado pela Alemanha na União Européia, e essa seria uma questão complexa e ao mesmo tempo extremamente relevante, do ponto de vista político, para avaliar a viabilidade da construção econômica e jurídica de uma moeda única no Mercosul.

No que concerne à Alemanha, há que se destacar que a sua moeda nacional, tal como adotada no passado, o marco alemão, constituiu-se em referencial para as outras moedas e âncora para o movimento integrador em território europeu, inclusive desde muito antes da implementação da União Européia. Nessa esteira, é interessante destacar que a moeda virtual criada pelo Sistema Monetário Europeu em 1971, a "Unidade Monetária Européia" (ECU, sigla em inglês ${ }^{325}$ ), composta por várias moedas européias, possuía como principal moeda integrante, o marco alemão. Todos os Estados-Membros deveriam manter suas taxas de câmbio fixas em relação à ECU, com a possibilidade de ajustes ao longo do tempo.

Levando em consideração que a Alemanha era a segunda economia do mundo na década de 1970, que a sua moeda era muito usada nas transações internacionais e que o Banco Central alemão tinha muita credibilidade em seu combate à inflação e por manter taxas de câmbio relativamente constantes, é fácil entender o motivo para o marco alemão ter sido considerado a moeda principal dentre as moedas então relacionadas pela ECU.

325 "European Currency Unit”. 
Avançando um pouco no tempo, ainda dentro do contexto da ancoragem do marco alemão em relação às demais moedas européias, é interessante mencionar que a ECU ${ }^{326}$ é uma espécie de "caldeirão", composta por porcentagens específicas das moedas nacionais de todos os Estados membros, sendo o marco alemão a que detém maior porcentagem.

A porcentagem prevista em $1992^{327}$ para cada moeda era a seguinte: coroa dinamarquesa, 2,52\%; marco alemão, 30,36\%; franco belga 7,78\%; franco francês, 19,32\%; escudo, 0,78\%; florim holandês, 9,49\%; peseta, 5,15\%; franco luxemburgês, $0,31 \%$; lira italiana, 9,87\%; pound irlandês, $1,111 \%$; dracma, $0,7 \%$; libra esterlina, $12,60 \%$.

Levando em consideração a porcentagem de cada moeda em 1992, tal como supramencionado percebe-se, mais uma vez, a força do marco alemão em relação às demais moedas visando à maior integração das mesmas, ainda que, na época, não se pudesse falar em moeda única implementada, já que o euro, efetivamente, só passou a vigorar em 1999.

Contudo, deve-se entender que, ainda que a ancoragem do marco alemão seja um referencial para a possibilidade de implementação da ancoragem das moedas dos Estados Partes do Mercosul no real, a experiência de ancoragem já aplicada em território latinoamericano e a implementada em território europeu (por intermédio do marco alemão) possuem sensíveis diferenças que, se insuperáveis, podem redundar em fracasso de tal medida com vistas à adoção da moeda única no Mercosul.

Abordando as diferenças existentes entre a ancoragem cambial implementada no território latino-americano e no território europeu, BATISTA JÚNIOR ${ }^{328}$ esclarece o seguinte:

\footnotetext{
Nesse particular, as âncoras cambiais latino-americanas diferem de modo fundamental da ancoragem no marco alemão, que constituía a essência do mecanismo cambial europeu. Na Europa Ocidental, o sistema de taxas fixas ou quase fixas resultava de um entendimento multilateral e contava, portanto, não apenas com o respaldo dos governos e bancos centrais das moedas historicamente mais fracas, mas também com o compromisso da Alemanha e do Bundesbank de atuarem no sentido de dar sustentação ao sistema, inclusive intervindo de forma coordenada com os outros

326 “O ECU (...) foi introduzido no primeiro dia do mês de janeiro de 1979 e seu nome lembra uma antiga moeda, o écu, cunhado em França entre 1266 e 1270, quando da introdução de um sistema monetário uniforme." BARROS. Op. cit., p. 265.

${ }^{327}$ BARROS. Op. cit., p. 266.

${ }^{328}$ BATISTA JUNIOR, Paulo Nogueira. Dolarização: significado e conseqüências. Econômica, $\mathrm{n}^{\circ}$ 3, jun. 2000, p. 37-62, p.47
} 
governos e bancos centrais para manter as taxas cambiais dentro das faixas acordadas ${ }^{329}$.

Paralelamente ao exemplo da Alemanha na Europa, pode-se pensar na possibilidade do Brasil tornar-se, formalmente, referência, com a definição de sua moeda como moeda âncora para as demais moedas pertencentes aos outros Estados Partes do Mercosul, visando à superação de dificuldades e complexidades para a implementação de uma moeda única no Mercosul.

O Brasil pela sua dimensão, pelas potencialidades de sua economia, poderia representar papel idêntico no Mercosul, sendo seu desempenho fundamental nessa evolução futura?

Nesse particular, uma análise um tanto precipitada poderia levar a uma resposta positiva. Entretanto, parece-nos, s.m.j., que a comparação é insustentável. Há que se levar em conta que Brasil e Alemanha têm pesos absolutamente distintos, numa e noutra época histórica, pois os fatores de supremacia, força e liderança geopolítica são completamente diferentes. No caso do Brasil, da mesma forma como aconteceu com a Alemanha, o peso político dos demais parceiros tenderia, com muito maior intensidade, a nivelar essa influência, fazendo com que se atingisse um nivelamento por baixo a médio ou até curto prazo.

\section{3 - A Flexibilização da Soberania com a Adoção de uma Moeda Única}

A soberania, em conformidade com o pensamento de $\operatorname{JELLINEK}^{330}$, é uma concepção política que só mais tarde se converteu em uma concepção de índole jurídica. Sobre a evolução do conceito, segue LOBO:

Começa sendo um fundamento político-filosófico que procura legitimar o poder concentrado, seguindo-se como uma categoria político-jurídica para fundar, legitimando-a, a concentração do poder nos Estados nacionais e se apresenta mais tarde como perseguindo considerações de seguridade, de desenvolvimento econômico e de bem-estar para permitir aos Estados ligarem-se mais estreitamente com outros, complementando-

${ }^{329}$ BATISTA JUNIOR, Paulo Nogueira. Dolarização: significado e conseqüências. Econômica, $\mathrm{n}^{\circ}$ 3. jun. 2000 , p. 47.

330 JELLINEK, Georg. Teoria General Del Estado. Cidade do México. Fundo de Cultura Econômica. 2002, p. 401. 
se, sem confundirem-se, para alcançar resultados que o avanço da civilização tornava impossíveis no campo da soberania clássica ${ }^{331}$.

A despeito da concepção original atribuída à soberania, segundo a qual em um território determinado não se pode exercer senão uma soberania, fato é que, atualmente, questiona-se sobre a possibilidade de extinção da soberania em face do incremento de movimentos de integração implementados pelos Estados. Nesse sentido, a integração poderia cercear ou limitar a soberania dos Estados envolvidos em um dado processo de integração sem que tal atitude resultasse na extinção da soberania dessas entidades políticas.

Conforme MALISKA ${ }^{332}$, uma das dúvidas com a qual se deparam aqueles que pensam sobre o aprofundamento do processo de integração é acerca do melhor caminho a seguir: o da supranacionalidade ou o da intergovernabilidade. O mencionado autor aproveita, então, para formular um questionamento: "Será que é possível avançar significativamente na integração mantendo o seu caráter intergovernamental, o respeito irrestrito à soberania dos países-membros traduzido, basicamente, na tomada de decisões por unanimidade com necessidade de ratificação interna pelos parlamentos nacionais?”.

Respondendo positivamente à pergunta, posicionam-se aqueles que temem, justamente, entre outros pontos, pela extinção da soberania, já que a tomam em sua concepção tradicional. No entanto a doutrina aponta majoritariamente em sentido diverso, visto que o conceito vem adquirindo outra significação em face da realidade atual ${ }^{333}$.

Contemporaneamente à globalização ${ }^{334}$, e muito em conseqüência dela, produziuse uma relativização do conceito de soberania. Essa relativização deu-se em relação à sua partilha. Nessa concepção, segundo LOBO, "são os Estados, no pleno uso das suas faculdades soberanas, que transferem o exercício de parcelas de suas competências. $\mathrm{O}$ Estado não desaparece, mas o seu papel já não é o mesmo”335.

\footnotetext{
${ }^{331}$ LOBO, Maria Teresa de C. O direito da integração nas constituições dos Estados-partes do Mercosul. a Constituição do Brasil. Revista de Derecho del Mercosur, nº 2, abril de 1999, p. 20.

332 MALISKA, Marcos Augusto. A supranacionalidade no Mercosul: a transferência de direitos de soberania e o problema da legitimidade democrática. Cadernos da Escola de Direito e Relações Internacionais da UniBrasil, vol. 5, jan./dez. 2005, p. 107.

333 Idem.

334 "A globalização é um fenômeno social, consistente na aproximação de distâncias geográficas e na homogeneização das expectativas de consumo, de práticas políticas decorrentes da globalização econômica". RIBEIRO, Maria de Fátima. Op. cit., p. 10.

${ }^{335}$ LOBO. Op. cit., p. 19.
} 
Em reforço, está o entendimento de CAMINHA, ao afirmar que a flexibilização da noção de soberania, não significa a sua perda ${ }^{336}$, o que está de acordo com as assertivas de SUTHERLAND ${ }^{337}$. Ainda nesse sentido, MELLO assevera que a soberania pode ser limitada ou dividida sem que, para isso seja perdida. O Estado dotado de soberania continua a existir, e o que ele delega aos organismos internacionais são apenas algumas de suas competências ${ }^{338}$.

Ainda sobre o tema, MARTINS FARIA acrescenta que, já a partir do período pós $2^{a}$ Guerra Mundial, a internacionalização da vida econômica, social e cultural dos países ensejou a tendência de relativa perda de substância da soberania estatal em favor do Direito Internacional, por intermédio da sistematização normativa, efetuada por meio de tratados internacionais, que "estabelece normas de conduta obrigatórias para seus signatários, tendo por fundamento a regra pacta sunt servanda, posto que assim são estabelecidas normas gerais de direito internacional criadoras de direitos e obrigações para disciplinar as relações entre os Estados singulares"339.

Assim, a realidade contemporânea de integração de mercados, levando os Estados a basear suas políticas numa análise objetiva das relações econômicas internacionais determinou uma nova conceituação de soberania, correspondente à sua divisibilidade, no sentido de que a substância do poder continua pertencendo ao Estado enquanto o exercício de determinadas competências é conferido a uma entidade nova da qual o Estado faz parte.

Explicando as causas do processo de relativização do conceito soberania, ROCHA afirma:

No momento presente, em que a soberania é do povo e não das nações e em que as idéias e as ideologias podem irmanar mais que a identidade do solo que constitui a pátria; no momento histórico em que a terra se converte em pátria da totalidade dos homens, em que o meio ambiente atinge a vida de todos os seres do planeta, qualquer que seja o local que se tome por referência, há que se pensar (...) que a soberania repensada, relativizada e centrada na participação política livre e permanente do povo pode servir ao resguardo da identidade de cada grupo cultural sem

\footnotetext{
${ }^{336}$ CAMINHA, Maria do Carmo P. A questão da soberania e da supranacionalidade na comunidade européia e no Mercosul. Revista de Derecho del Mercosur / Doctrina Internacional y Comparada. $\mathrm{n}^{\text {o }}$ 6, dic. 1999, p. $88-95$, p. 89.

${ }^{337}$ SUTHERLAND, Peter. Em defesa da união monetária européia. Foreign Affairs, edição brasileira, jan. 1997 , p. 19-22.

${ }^{338}$ MELLO, Celso D. Albuquerque. Direito Internacional da Integração. Rio de Janeiro, Renovar, 1996, p. 123.

${ }^{339}$ FARIA, Fábio Martins. A Defesa Comercial: Origens e Regulamentação das Medidas Antidumping, Compensatórias e de Salvaguardas. São Paulo: Aduaneiras, 2003, p. 13.
} 
perda da dimensão universal da convivência política. Mas parece indubitável que a soberania não pode persistir como conceito que se ponha como bloqueio para que venham as modificações que a nova ordem internacional, as novas formas de solidariedade entre os homens nos diversos Estados e a experiência de universalização e mundialização dos direitos fundamentais do homem propõem e põem. Por isso é que se tem enfatizado a desmaterialização cada vez maior da soberania e a sua aceitação sempre mais como conceito formal, que não embaraça nem impede a internacionalização dos contatos e relações entre os Estados e, principalmente, entre os sistemas garantidores dos direitos humanos ${ }^{340}$.

A integração no Continente Europeu surge mais uma vez vem como exemplo paradigmático: os Estados europeus, com forte sentimento nacionalista, limitaram e relativizaram alguns de seus poderes soberanos visando ao interesse comunitário, mantendo, porém, plena identidade e independência. Não foram absorvidos uns pelos outros. Assim, a flexibilização da noção clássica de soberania propiciou a melhora do nível de aproximações entre os Estados-Membros, tornando-os, pelo conjunto, mais prósperos e fortalecidos como potência mundial ${ }^{341}$.

A propósito, MEDINA OSÓRIO ${ }^{342}$ refere que, “em verdade, são muitas as dificuldades para unificação institucional de poderes em alguma entidade supranacional, tanto que o próprio fenômeno da unificação européia passa, historicamente, pelo consenso dos Estados-Membros, que ratificam os Tratados, ajustando suas respectivas Constituições e leis aos novos paradigmas. E assim será, também, em outros cenários de possível unificação ou organização de blocos econômicos".

Todavia, a atuação em bloco não pressupõe necessariamente a adoção de moeda única. A implementação dessa ferramenta, altamente impactante no conceito de soberania, pressupõe um conjunto de fatores históricos, políticos e geográficos muito específicos.

A combinação de moeda única com o respeito aos critérios macroeconômicos de convergência pode diminuir a capacidade de ação dos governos, afetando, desse modo, a soberania nacional e os espaços de manobras políticas diante das peculiaridades locais. A adoção de uma moeda única representa uma renúncia ao uso de instrumentos clássicos de política econômica, em particular da política cambial, o que coloca em um plano subalterno a nacionalidade da moeda. De um lado, os governos perdem a possibilidade de usar a política cambial como instrumento de ajuste e, de outro, a necessidade de respeitar

340 ROCHA, Carmen Lúcia Antunes. Constituição, soberania e Mercosul. Revista de Informação Legislativa, $\mathrm{n}^{\circ}$ 139, jul./set. 1998, p. 297.

${ }^{341}$ CAMINHA. Op. cit., p. 95.

342 MEDINA OSÓRIO, Fábio. Direito Administrativo Sancionador. 2. edição. São Paulo: Revista dos Tribunais, 2006, p. 130. 
certos parâmetros macroeconômicos limita a possibilidade de incorrer em políticas expansionistas, geradoras de déficits e/ou inflação.

Além dos supramencionados problemas relacionados à adoção de moeda única, estágio ao qual só é possível chegar através da flexibilização da soberania, um Estado que não aderir à unificação monetária do bloco, tendo essa faculdade, poderá extrair benefícios dessa estratégia se, não se amarrando aos compromissos da unificação, não tiver modificado o seu status quo, no caso, por exemplo, desta integração ser um fracasso.

Ainda que na prática não se possa evitar algum tipo de relacionamento e flexibilização da soberania em relação às decisões de terceiros, ainda mais no que toca à moeda, já que não existe sistema monetário isolado dos demais sistemas monetários do mundo, a unificação monetária envolve uma perda maior, ainda que parcial, de soberania para a gestão de certas políticas públicas.

É de se questionar se a instrumentalidade jurídica atualmente existente no seio do Mercosul pode ser eficaz frente às necessidades de uma união monetária. Questiona-se, especialmente, a capacidade da previsão legal sobre incorporação legislativa das normas do Mercosul de cada um dos Estados Partes para regular as relações decorrentes de uma união monetária. Nesse sentido, surge especial interesse pelas disposições dos arts. 40 e 42 do Protocolo de Ouro Preto (POP), in verbis:

Artigo 40 - A fim de garantir a vigência simultânea nos Estados Partes das normas emanadas dos órgãos do Mercosul previstos no Artigo $2^{\circ}$ deste Protocolo, deverá ser observado o seguinte procedimento:

i) Uma vez aprovada a norma, os Estados Partes adotarão as medidas necessárias para a sua incorporação ao ordenamento jurídico nacional e comunicarão as mesmas à Secretaria Administrativa do Mercosul;

ii) Quando todos os Estados Partes tiverem informado sua incorporação aos respectivos ordenamentos jurídicos internos, a Secretaria Administrativa do Mercosul comunicará o fato a cada Estado Parte;

iii) As normas entrarão em vigor simultaneamente nos Estados Partes 30 dias após a data da comunicação efetuada pela Secretaria Administrativa do Mercosul, nos termos do item anterior. Com esse objetivo, os Estados Partes, dentro do prazo acima, darão publicidade do início da vigência das referidas normas por intermédio de seus respectivos diários oficiais.

Artigo 42 - As normas emanadas dos órgãos do Mercosul previstos no Artigo $2^{\circ}$ deste Protocolo terão caráter obrigatório e deverão, quando necessário, ser incorporadas aos ordenamentos jurídicos nacionais mediante os procedimentos previstos pela legislação de cada país. 
Pela simples aplicação dos artigos 40 c/c 42 do POP, poder-se-ia pensar na possibilidade de não ser necessária a alteração do grau de soberania despendido em favor da união monetária visto que os ordenamentos jurídicos internos absorveriam, de acordo com o que dispõe cada ordenamento constitucional dos Estados Partes, o ordenamento do bloco.

Contudo, notadamente em face do exemplo supranacional da União Européia, parece distante a possibilidade de que tais dispositivos (40 e 42) possam, por si só, regular com eficácia a relação jurídica de integração que se pretende implementar.

Na Europa, a questão da soberania foi colocada em menor patamar se comparada ao grande projeto da construção européia e dos objetivos traçados para a introdução do euro, principalmente com relação à estabilidade dos preços e ao crescimento econômico sustentado. Acontece que, em relação ao Mercosul, não é apenas essa problemática da perda de soberania que entrava a adoção de uma moeda única, mas para muito além dela, outras precondições que dificilmente serão superadas, dentre elas a própria integração regional.

Por outro lado, há que se reconhecer que os resultados demonstrados pelo Grupo de Trabalho $\mathrm{n}^{\mathrm{o}}$ 4, do Mercosul, são os primeiros sinais de integração dos mercados financeiros, que certamente seriam mais fortalecidos com um poder monetário central, o que pode ser pensado como medida de médio prazo. Daí, então, outros passos para a implantação da moeda comum poderão ser engatilhados, no que, nesse aspecto, estamos de acordo RIBEIRO ${ }^{343}$.

${ }^{343}$ RIBEIRO. Op. cit., p. 24. 


\section{CAPÍTULO VI}

\section{A BUSCA DA INTEGRAÇÃO NO MERCOSUL}

A busca da integração no Mercosul é analisada levando em consideração a realidade do bloco, apresentando, por meio da exposição de "dificuldades e incertezas", "tentativa de integração" e "dificuldades jurídicas a superar", a base contextual do Mercosul sobre a qual expomos nossa posição no que tange à impossibilidade de implementação da moeda única na dimensão sócio-política e jurídica atual.

\section{1 - Dificuldades e Incertezas}

O estudo das dificuldades e incertezas do Mercosul leva em consideração aspectos como a situação estrutural do bloco; o grau de integração até então consolidado; o relacionamento entre os dois principais membros do bloco e a constatação de que o fluxo comercial ainda é o principal componente do balanço de pagamentos intrabloco, especialmente centrado em determinantes da balança comercial Brasil / Mercosul.

\subsubsection{A Estrutura Institucional Minimalista do Mercosul e a Metodologia de Integração}

O Mercosul foi criado frente a grandes expectativas e elevados anseios dos representantes dos Estados Partes. Contudo, uma vez constituído o Mercosul ${ }^{344}$ pelo Tratado de Assunção (TAs) ${ }^{345}$, assinado em 26 de março de 1991, o que se percebeu foi a existência de uma profunda assimetria interna entre o propósito constitutivo ambicioso (constituição de um mercado comum, nos termos do art. $1^{\circ}$ do TAs) e a fragilidade dos

\footnotetext{
344 "O ato constitutivo de uma organização internacional distingue-se de outras convenções multilaterais por ser o ato - fundação da organização, ao qual ela estará ligada ao longo de toda a sua existência. Ele vai gerar uma vida própria da instituição que ultrapassa o contexto no qual ela inicialmente foi concebida.” BETTATI, Mario. Le droit des organizations internationales. Paris: PUF, 1987, p. 38

${ }^{345}$ Tratado para a Constituição de um mercado comum entre a República Argentina, a República Federativa do Brasil, a República do Paraguai e a República Oriental do Uruguai, disponível em $<$ http://www.mercosur.int>. Acesso em: 21 nov. 2008.
} 
meios colocados à sua disposição pelos Estados Partes (nos termos dos arts. $9^{\circ}$ e 15 do TAs $)^{346}$. Nessa linha de argumentação, interessante a exposição integral do conteúdo dos artigos mencionados:

Artigo $1^{\mathbf{0}}$ - Os Estados Partes decidem constituir um Mercado Comum, que deverá estar estabelecido a 31 de dezembro de 1994, e que se denominará "Mercado Comum do Sul" (Mercosul).

Este Mercado Comum implica:

A livre circulação de bens serviços e fatores produtivos entre os países, através, entre outros, da eliminação dos direitos alfandegários, restrições não tarifárias à circulação de mercado de qualquer outra medida de efeito equivalente;

O estabelecimento de uma tarifa externa comum e a adoção de uma política comercial comum em relação a terceiros Estados ou agrupamentos de Estados e a coordenação de posições em foros econômico-comerciais regionais e internacionais;

A coordenação de políticas macroeconômicas e setoriais entre os Estados Partes - de comércio exterior, agrícola, industrial, fiscal, monetária, cambial e de capitais, de serviços, alfandegária, de transportes e comunicações e outras que se acordem -, a fim de assegurar condições adequadas de concorrência entre os Estados Partes; e

O compromisso dos Estados Partes de harmonizar suas legislações, nas áreas pertinentes, para lograr o fortalecimento do processo de integração.

Artigo $9^{\circ}$ - A administração e execução do presente Tratado e dos Acordos específicos e decisões que se adotem no quadro jurídico que o mesmo estabelece durante o período de transição estarão a cargo dos seguintes órgãos:
a) Conselho do Mercado Comum;
b) Grupo do Mercado Comum.

Artigo 15 - O Grupo Mercado Comum contará com uma Secretaria Administrativa cujas principais funções consistirão na guarda de documentos e comunicações de atividades do mesmo. Terá sua sede na cidade de Montevidéu.

Com o Protocolo de Ouro Preto (POP) $)^{347}$, de 1994, houve um fortalecimento jurídico do bloco uma vez que passou a ter personalidade jurídica de direito internacional. Além disso, houve um reforço do entendimento de quais órgãos faziam parte do Mercosul, através da precisão constante do art. $1^{\circ}$ do referido protocolo. Segue a integralidade do artigo mencionado:

\footnotetext{
346 “(...) Daí resulta que o TAs associa uma surpreendente firmeza na escolha de seu destino a uma singular leveza na escolha dos meios que lhe permitirão atingir seus objetivos". VENTURA, Deisy. As Assimetrias entre o Mercosul e a União Européia: os desafios de uma associação inter-regional. São Paulo: Manole, 2003, p. 41.

${ }^{347}$ Protocolo de Ouro Preto - Protocolo Adicional ao Tratado de Assunção sobre a Estrutura Institucional do Mercosul. Disponível em: <http:www.mercosur.int>. Acesso em: 23 nov. 2008.
} 
Artigo $1^{\circ}$.

A estrutura institucional do Mercosul contará com os seguintes órgãos:

I - O Conselho do Mercado Comum (CMC)

II - O Grupo Mercado Comum (GMC)

III - A Comissão de Comércio do Mercosul (CCM)

IV - A Comissão Parlamentar Conjunta (CPC)

V - O Foro Consultivo Econômico-Social (FCES)

VI - A Secretaria Administrativa do Mercosul (SAM)

Parágrafo Único - Poderão ser criados, nos termos do presente Protocolo, os órgãos auxiliares que se fizerem necessários à consecução dos objetivos do processo de integração.

Analisando-se a legislação supracitada, pode-se afirmar que o Mercosul adota uma estrutura típica das organizações internacionais de caráter regional, paradoxalmente movida por uma dinâmica institucional que se assemelha ao funcionamento de um simples entendimento intergovernamental.

Adentrando na metodologia adotada para relacionar os Estados, têm-se duas opções metodológicas: a integração e a cooperação.

A “integração" refere-se à interpenetração, enquanto que a cooperação refere-se a "trabalhar com". Na integração, os parceiros se fundem, perdendo a individualidade. Já na cooperação, deve existir duas ou mais soberanias que tomam decisões por unanimidade (não há um órgão superior, apenas organismos com representação ministerial e diplomática).

Trazendo o estudo metodológico para o Mercosul, percebe-se que nele adota-se a metodologia da “cooperação". Neste diapasão, é o que ensina GOMES:

No Mercosul (...) o mecanismo de funcionamento é pautado por princípios de Direito Internacional Público e, neste sentido, cada EstadoParte atua na defesa de seus próprios interesses, com vistas a resguardar sua própria soberania, pois as deliberações acerca dos objetivos do bloco econômico não predominam em relação àquelas dos seus integrantes. É a chamada coordenação de soberanias, pois as deliberações acerca dos objetivos do bloco econômico não predominam em relação àquelas dos seus integrantes ${ }^{348}$. (grifamos)

O Conselho do Mercado Comum (um dos órgãos do Mercosul - tal como previsto no anteriormente mencionado art. $9^{\circ}$ do POP) é exemplo a ser destacado, tendo em vista

\footnotetext{
${ }^{348}$ GOMES, Eduardo Biacchi. A adoção do instituto da supranacionalidade no Mercosul. Revista da Faculdade de Direito da UFPR, vol. 35, Curitiba, 2001, p. 278.
} 
ser um órgão de coordenação interministerial. Nesse sentido, interessante a leitura do artigo $2^{\circ}$ e $7^{\circ}$ do POP:

Artigo $2^{\circ}$ - São órgãos com capacidade decisória, de natureza intergovernamental, o Conselho do Mercado Comum, o Grupo Mercado Comum e a Comissão de Comércio do Mercosul.

Artigo $7^{\circ}$ - As reuniões do Conselho do Mercado Comum serão coordenadas pelos Ministérios das Relações Exteriores e poderão ser convidados a delas participar outros Ministros ou autoridades de nível ministerial.

Levando-se em consideração que a implantação de uma moeda única no seio de um bloco econômico demanda um fortalecimento dos laços entre os Estados envolvidos, é pertinente pensar que a moeda única poderá ser melhor assimilada e desenvolvida em um ambiente de integração e supranacionalidade (tal como o exemplo europeu, através da União Européia, deixa transparecer) do que em um ambiente de cooperação e intergovernabilidade (tal como o atual ambiente existente no seio do Mercosul, a despeito das metas e pretensões expostos no já mencionado art. $1^{\circ}$ do TAs).

A estrutura institucional existente no Mercosul, bem como a metodologia de cooperação seguida no mesmo não se equipara àquela percebida no grande bloco referencial que se vale da moeda única (a União Européia), levando a sérios questionamentos acerca da capacidade de se implementar uma moeda única valendo-se de uma estrutura institucional minimalista e de uma metodologia cooperativa, questionamento este especialmente lançado sobre o Mercosul.

De acordo está ALMEIDA, seu entendimento é que "um dos grandes problemas da evolução política futura do Mercosul é, precisamente, o salto para a adoção integral de instituições comunitárias de tipo supranacional, transição que ocorrerá, mais cedo ou mais tarde, nos Países-Partes, considerando-se que o Mercosul constitui, efetivamente, o embrião de etapas superiores de integração"349.

Do mesmo modo, e como complemento, D’ANGELIS sustenta que "sem órgão jurisdicional independente e instituições decisórias supranacionais, sem harmonização legislativa e macroeconômica, sem órgãos autônomos e distintos dos respectivos governos

\footnotetext{
${ }^{349}$ ALMEIDA, Paulo Roberto. O Mercosul no contexto global. BASTOS, Celso Ribeiro; FINKELSTEIN, Cláudio (orgs.). Mercosul: lições do período de transitoriedade. São Paulo: Instituto Brasileiro de Direito Constitucional, 1998, p. 127.
} 
nacionais, dentre outros aspectos, não estamos diante de real integração e muito menos somos uma Comunidade de Nações" 350 .

Tais falhas metodológicas e institucionais podiam ser consideradas naturais na etapa fundacional ou mesmo nos primeiros anos de desenvolvimento do Mercosul. Entretanto, tais falhas devem ser agora consideradas visando o incremento da integração regional $^{351}$.

\title{
6.1.2 O Mercosul ainda é meramente uma União Aduaneira Imperfeita
}

A despeito de denominar-se Mercado Comum, o Mercosul é, na prática, uma União Aduaneira imperfeita. Com a assinatura do TAs, criou-se uma zona de livre comércio entre os quatro Estados Partes. A propósito, BARRAL 352 observa que "o arroubo inicial pela consecução do mercado comum teve de arrefecer diante das difículdades institucionais encontradas durante a fase de transição (1991-1994)".

Em um segundo momento, em 1995, a União Aduaneira teve início e, embora ainda imperfeita, e com todos os percalços inerentes à formação desse modelo de integração, segue assim sendo.

De acordo, e em acréscimo, dissertando acerca da imperfeição da união aduaneira constituída pelo Mercosul, segue GOMES:

\begin{abstract}
Considerando que no Mercosul a TEC não vigora para todos os produtos dos Estados-partes - pois é permitida a elaboração de uma lista de regime de adequação para os produtos que não têm livre circulação no bloco econômico e sobre os quais incidem tarifas diferenciadas, e de uma lista de exceções para os produtos oriundos de terceiros países e importados pelos Estados do Mercosul que não se utilizam da TEC -, torna-se atualmente inviável a consolidação da união aduaneira, e difícil, ao menos teoricamente, a sua passagem para o outro estágio do processo integracionista: o mercado comum ${ }^{353}$.
\end{abstract}

Ainda sobre o estágio atual do Mercosul, ROCHA preleciona no seguinte sentido:

350 D'ANGELIS, Wagner Rocha. Mercosul. Da intergovernabilidade à supranacionalidade? Perspectivas jurídicas para a efetivação do mercado comum. Curitiba: Juruá, 2000, p. 21 e 226.

351 PEÑA, Félix. Direito e instituições no Mercosul: um balanço de conquistas e insuficiências. In: AMBOS, Kai; PEREIRA, Ana Cristina.(Coord.) Mercosul e união européia: perspectivas da integração regional. Rio de Janeiro: Lumen Juris, 2006, p. 102-103.

${ }^{352}$ BARRAL, Welber. Defesa Comercial no Mercosul. In BASSO, Maristela (org.). Mercosul - Mercosur: Estudos em homenagem a Fernando Henrique Cardoso. São Paulo: Atlas, 2007, p. 467.

${ }^{353}$ GOMES, Eduardo Biacchi. Blocos econômicos e solução de controvérsias. 2. ed. Curitiba: Juruá, 2008, p. 54. 
O Mercosul ainda não pode ser considerado uma união aduaneira dita perfeita, pois estão em vigor, atualmente, vários institutos típicos de uma fase de implementação. Poderia ser caracterizada como uma união aduaneira imperfeita, ou ainda flexível, pois representa uma área em que estão presentes características de uma zona de livre-comércio com uma Tarifa Externa Comum que abrange uma determinada parcela de mercadorias ${ }^{354}$.

Tais assertivas se justificam. O Mercosul, depois de cumprida a fase de transição entre 1991 e 1994, passou a possuir, a partir de 1995, uma tarifa externa comum (TEC) ${ }^{355}$ cuja plena vigência estava prevista para 2006, meta não atingida. Além disso, os Estados Partes têm, por vezes, tomado iniciativas que "passam por cima" da TEC, baseados em argumentos macroeconômicos.

A aprovação de uma TEC, com as exceções conhecidas e com escala de redução gradativa até a uniformização, deveria impedir que interesses locais pressionassem os governos domésticos para que aplicassem medidas protecionistas. Contudo, a desconsideração “ad hoc” pelos Estados Partes do Mercosul em relação à TEC, baseados em argumentos macroeconômicos tem sido aprovada por seus parceiros, os quais têm referendado a maioria dos pleitos nesse sentido. Em resumo, a união aduaneira imperfeita passou a funcionar como uma zona de livre-comércio, também imperfeita, proporcionando aos Estados Partes as mudanças temporárias necessárias nas tarifas aduaneiras para atenderem a objetivos de política macroeconômica.

Constatada a realidade do bloco, faz-se necessário compreendê-la. A fím de atingir tal objetivo, segue transcrição e posterior análise do art. $1^{\circ}$ do Tratado de Assunção:

Artigo $1^{\circ}$ - Os Estados Partes decidem constituir um Mercado Comum, que deverá estar estabelecido a 31 de dezembro de 1994, e que se denominará "Mercado Comum do Sul" (Mercosul).

Este Mercado Comum implica:

A livre circulação de bens serviços e fatores produtivos entre os países, através, entre outros, da eliminação dos direitos alfandegários restrições não tarifárias à circulação de mercado de qualquer outra medida de efeito equivalente;

\footnotetext{
354 ROCHA, Maria da Conceição Ramos. Mercosul - alcances da união aduaneira no ordenamento jurídico brasileiro. Rio de Janeiro: Lúmen Júris, 1999, p. 24.

355 “A Tarifa Externa Comum (TEC) foi criada em 1994, pela Decisão 22/94 do Conselho Mercado Comum (CMC). Está composta pela Nomenclatura Comum do Mercosul (doravante NCM) e pela alíquota correspondente no nível de item (8 dígitos). A NCM baseia-se no Sistema Harmonizado da Organização Mundial de Alfândegas, sendo idêntico a este até o nível da subposição tarifária (seis dígitos). No âmbito do Mercosul são utilizados 8 dígitos, enquanto outros países utilizam uma clasificação com maiores níveis de desagregação (nono ao décimo segundo dígitos)." Sítio oficial do Mercosul. Disponível em: $<$ http://www.mercosur.int>. Acesso em: 24 nov. 2008.
} 
O estabelecimento de uma tarifa externa comum e a adoção de uma política comercial comum em relação a terceiros Estados ou agrupamentos de Estados e a coordenação de posições em foros econômico-comerciais regionais e internacionais;

A coordenação de políticas macroeconômicas e setoriais entre os Estados Partes - de comércio exterior, agrícola, industrial, fiscal, monetária, cambial e de capitais, de serviços, alfandegária, de transportes e comunicações e outras que se acordem -, a fim de assegurar condições adequadas de concorrência entre os Estados Partes; e

O compromisso dos Estados Partes de harmonizar suas legislações, nas áreas pertinentes, para lograr o fortalecimento do processo de integração.

Ora, dissecando o transcrito artigo, não se encontra um desenho claro de qual seja a forma prevista para o modelo de mercado comum objetivado. Isso se explica, segundo BAPTISTA, porque "não se sabia ou quis determinar qual o desenho do mercado comum a que se aspira chegar. É conseqüência, possivelmente, da característica de pragmatismo que impõe flexibilidade e razoabilidade - e do caráter evolutivo do Mercosul”356.

FONTOURA vai além, ao defender que a estrutura transitória que caracteriza o Mercosul, explicada nos parágrafos anteriores, é a mais adequada ao modelo atual do bloco, uma vez que, em face das divergências comerciais entre os parceiros, a existência de qualquer entidade com poderes supranacionais levaria ao fracasso do bloco econômico, posto que os Estados Partes têm ainda muito arraigado o conceito de soberania ${ }^{357}$.

Em um bloco onde existem desigualdades econômicas entre os parceiros, a existência de mecanismos rígidos de funcionamento poderia contribuir para o seu insucesso, no que está de acordo GOMES ${ }^{358}$. Tendo o Mercosul tal característica, torna-se compreensível a flexibilidade de seus instrumentos normativos e a conseqüente peculiaridade da situação em que se encontra hoje, fruto de adaptação a desafios de integração únicos que o ambiente político-econômico sul-americano suscita.

\subsubsection{A Irrealística Divisão Igualitária de Poder entre os Estados Partes do Mercosul}

Há uma clara diluição de poder no seio do Mercosul que prejudica interesses individuais de Estados como o Brasil, que possui atuação bem mais relevante que a dos

\footnotetext{
${ }^{356}$ BAPTISTA, Luiz Olavo. O Mercosul, suas instituições e ordenamento jurídico. São Paulo: LTr, 1998, p. 52.

357 FONTOURA, Jorge. Solução de controvérsias e efetividade jurídica: as perspectivas do Mercosul. Revista do Senado Federal. Brasília, a. 33, n 130, 1998, p. 67 e ss. Importante acrescentar que, pelo fato desse bloco pretender ir além de uma mera zona de livre comércio e já estar dentro de uma união aduaneira, que pressupõe uma tarifa externa comum e uma política comercial comum, a cessão de soberania por parte dos Estados Partes é sensivelmente maior do que em uma mera zona de livre comércio, mas bem inferior à necessária para a consolidação de um mercado comum.

${ }^{358}$ GOMES. Op. cit., p. 55.
} 
demais Estados Partes do bloco no plano internacional, assim como do próprio Mercosul frente à fragilidade com que as negociações desenvolvidas por este são implementadas.

O Mercosul, por exemplo, não possui nenhum mecanismo decisório que seja ponderado em função do peso relativo dos seus membros, cabendo a todos eles um poder igualitário de veto sobre toda e qualquer decisão ou resolução ${ }^{359}$. Apontando as características institucionais do bloco, KNOLL DE BERTOLOTTI justamente indica que no Mercosul há um sistema de tomada de decisões que ocorre somente por consenso e com a presença de todos os membros ${ }^{360}$. O Parlamento do Mercosul, da mesma forma, foi constituído com base numa representação igualitária, não proporcional.

Nesse sentido, também, FLOH ${ }^{361}$ quando constata "a opção dos membros do Mercosul pela cooperação, sem qualquer referência a um eventual processo de integração, tal como proposto pelo Regionalismo Clássico. Exemplo desta situação é a inexistência de instituições, ou órgãos, de caráter supranacional, prevalecendo sempre durante o processo decisório a regra do consenso".

Tal situação é compreensível pelo fato de que, ao contrário do processo do direito comunitário europeu, a integração no Mercosul é pautada pelos princípios gerais do Direito Internacional Público, já que, como exposto em momento anterior, não existem instituições supranacionais no bloco. Exercita-se nele a intergovernabilidade tão-somente.

No que toca ao Mercosul, o mecanismo de tomada de decisões está regulamentado pelo art. 37 do Protocolo de Ouro Preto:

Art. 37. As decisões dos órgãos do Mercosul serão tomadas por consenso e com a presença de todos os Estados Partes.

Assim, há inexistência de vinculação direta dos Estados às decisões e normas de direito derivado emanadas dos órgãos do Mercosul, por faltar a elas efetiva coercibilidade

\footnotetext{
359 "No Mercosul, a intergovernamentabilidade adotada pelo processo de integração, tem como característica manter atrelada as decisões do bloco econômico à vontade política dos Estados-membros. As decisões resultam exclusivamente do consenso, sua estrutura institucional e seus funcionários dependentes exclusivamente dos interesses dos Estados Parte7. Daí, o que se pode chamar de limitações ao avanço do bloco.” ARAÚJO, Luis; MARTINEZ, Mônica. Análise Comparada da Integração no Mercosul e na União Européia. Revista dos Alunos do Programa de Pós-Graduação em Integração Latino-Americana, Florianópolis, UFSM, vol. 2, nº 1, 2005, p. 12.

${ }^{360}$ KNOLL DE BERTOLOTTI, Silvina Barón. Órganos de administración y gobierno del Mercosur. Buenos Aires: Depalma, 1997, p. 145.

${ }^{361}$ FLOH, Fabio. Direito Derivado do Mercosul: Natureza Jurídica e Integração aos Ordenamentos Jurídicos Internos. In: BASSO, Maristela (org.). Mercosul - Mercosur: Estudos em homenagem a Fernando Henrique Cardoso. São Paulo: Atlas, 2007, p. 258.
} 
e sanção. As decisões são tomadas por consenso e com a presença de todos os membros, e a vigência das normas emanadas de seus órgãos é precedida da respectiva internalização na ordem jurídica dos Estados. Portanto, vigem os princípios da reciprocidade e pacta sunt servanda e, consoante ao já afirmado, todos os Estados Partes têm o mesmo poder de decisão dentro do bloco.

Com a conformação de uma ordem mundial de mercados abertos e globais e a emergência progressiva de novos atores no plano internacional, o Brasil vem experimentando, igualmente, mudanças sensíveis em seu papel regional e como ator global, ocupando posição singular, não necessariamente única, mas específica, a seu modo, no sistema de relações internacionais contemporâneas. Trata-se certamente de um país continente que, em análises exploratórias, já pôde ser enquadrado na categoria de "paísesbaleia”, ${ }^{362}$, como os EUA, a Rússia e a China.

A estruturação do poder entre os Estados Partes do Mercosul, ao invés de ser um grande ponto positivo no intuito de inserção internacional concomitante ao reforço de poder dos Estados Partes, analisando-se sob o prisma brasileiro, reflete, pelo contrário, uma perda significativa de poder, apesar de seu papel internacional notoriamente diferenciado em relação aos demais Estados que participam do Mercosul. Nesse sentido, os próprios desacordos entre os Estados Partes quanto às suas prioridades respectivas e a desconfiança histórica em relação ao peso específico do Brasil vêm dificultando o exercício da potencial "liderança natural" do Brasil numa região ainda pouco integrada fisicamente - os obstáculos geográficos são respeitáveis - e com grandes disparidades econômicas e sociais - as chamadas "assimetrias".

Levando em consideração que o Brasil exerce liderança relativa em alguns tópicos da agenda multilateral (como nas negociações comerciais multilaterais, por exemplo) e tem sido considerado um ator relevante, como um dos BRICs ${ }^{363}$, na evolução futura da economia mundial, é de se sopesar seu real interesse em um envolvimento mais profundo em relação ao Mercosul, diante da deficitária inserção internacional do bloco conjuntamente ou, ao menos, na diminuição da autonomia do Brasil ao compor o Mercosul, analisada a em relação à que lhe é possibilitada por uma inserção independente no cenário internacional.

\footnotetext{
362 Também podendo ser definido como "monster-country” ou país âncora.

${ }^{363}$ BRIC é um acrônimo criado em novembro de 2001 pelo economista Jim O’Neill, do grupo Goldman Sachs, para designar os quatro principais Estados emergentes do mundo, a saber: Brasil, Rússia, Índia e China, no relatório "Building Better Global Economic Brics".
} 
Por fim, cabe destacar que a política externa de muitos Estados, a exemplo do Brasil, é chamada a desempenhar um papel auxiliar no processo de desenvolvimento. Daí a importância avaliar o interesse e as vantagens, de manter-se uma estrutura decisória destoante da real capacidade de cada um dos Estados Partes, uma vez esse coloca em risco o exercício da plena potencialidade de cada um dos Estados na dinâmica de inserção e atuação em plano internacional.

\subsubsection{A Relação entre os Dois Principais Parceiros do Mercosul}

A História dos laços bilaterais revela que as relações entre Brasil e Argentina se iniciam sob o signo da instabilidade estrutural no século $\mathrm{XIX}^{364}$ e avançam rumo à estabilidade estrutural pela integração no século XXI. Nesse percurso, passam pelas fases de instabilidade conjuntural e busca de cooperação (1898-1961), instabilidade conjuntural com rivalidade (1962-1979), construção da estabilidade estrutural pela cooperação (19791987) e pela integração (desde 1988).

A construção da estabilidade estrutural pela cooperação pode ser exemplificada através da assinatura das Atas de Iguaçu, em 1985, pelos presidentes Sarney ${ }^{365}$ e Alfonsín $^{366}$, encerrando uma era de desconfianças entre Brasil e Argentina. Já a construção da estabilidade por meio da integração pode ser verificada com a celebração em 1988 do Tratado de Integração, Cooperação e Desenvolvimento entre Brasil e Argentina, consolidando o processo de aproximação bilateral e estabelecendo mecanismos para a criação de um espaço econômico comum no prazo máximo de dez anos ${ }^{367}$.

É preferível analisar a relação entre Brasil e Argentina calcando-se especialmente nos dois Estados, a despeito da influência de terceiros, pois tal relação sempre demonstrou ter uma dinâmica própria que resulta do desequilíbrio de poder entre os dois Estados. Constatado esse desequilíbrio, abrem-se historicamente dois caminhos: a busca do

\footnotetext{
364 “As divergências entre os Estados - partes do Mercosul não são recentes, podendo-se perceber conflitos de interesses entre as populações da região desde o início do povoamento desta. (...) Desde à época em que a região era Colônia de Portugal e Espanha, percebe-se a existência de conflitos políticos, econômicos e militares." LECH, Marcelo; MOREIRA, Luiz Carlos. Associação entre Mercosul e união européia: realidade ou utopia? Canoas: Editora da ULBRA, 2006, p. 20.

${ }^{365}$ Presidente do Brasil de 1985 até 1990, eleito pelo Congresso Nacional como Vice - presidente de Tancredo Neves, que morreu antes de assumir o cargo. Primeiro presidente civil depois de 1964. O período de seu mandato é conhecido como "transição democrática" ou "Nova República".

${ }^{366}$ Presidente da Argentina entre 1983 e 1989, foi o primeiro a ser eleito por sufrágio universal desde 1974. Não conseguiu completar o mandato. O país tornou-se ingovernável devido à crise econômica provocada pelo processo conhecido como "hiperinflação".

${ }^{367}$ LECH e MOREIRA. Op. cit., p. 24.
} 
reequilíbrio ou da contenção (jogo de soma zero) ${ }^{368}$ ou a construção de poder compartilhado diante do mundo (jogo de soma positiva) ${ }^{369}$.

O Brasil e a Argentina seguiram institucionalidades e políticas cambiais opostas e excludentes. Nos primeiros anos do Plano Real ${ }^{370}$, a política cambial do Brasil camuflou estas diferenças e o problema ficou escondido. Contudo, a partir da efetiva flutuação do real e, após a fase terminal da crise argentina e da desvalorização do real ao longo do ano de 2002, a crise estourou com vigor.

É verdade que o Brasil e a Argentina tomaram iniciativas visando tentar fortalecer o Mercosul. Inclusive, ambos concordaram em criar mecanismos temporários de salvaguarda no comércio recíproco. O objetivo alegado foi o de permitir que o Mercosul ultrapassasse as dificuldades criadas pela crise argentina.

As discussões sobre salvaguardas compensatórias e uma enorme lista de exceções foram o alto preço pago pelo Brasil para manter a âncora da TEC. As justificativas para esses acontecimentos no Mercosul fundamentaram-se na crise internacional que se presenciava, à época, e que, agora se agrava com a atual mais recente crise mundial que a todos afeta.

Os governos brasileiro e argentino procuram destacar que as salvaguardas mostram que há flexibilidade no Mercosul, bem como reiteram o caráter crucial da TEC, no sentido de reafirmar o objetivo de constituir, a médio prazo, uma moeda comum para o bloco.

Apesar das convergências existentes e das aproximações ocorridas, é fato que as agendas dos dois governos nem sempre coincidem, gerando rivalidades e desconfianças que determinam visões distintas de curto e médio prazo, seja do ponto de vista político, seja comercial $^{371}$. A título de ilustração, basta visualizar os laudos arbitrais até hoje proferidos pelo Tribunal Arbitral do Mercosul para se ter uma idéia acerca de como entram

\footnotetext{
${ }^{368}$ Entre dois jogadores, um necessariamente ganha na mesma proporção em que o outro perde. Assim sendo, se um nada ganha, também o outro nada perde. Normalmente, o jogo de soma zero simboliza para as relações internacionais aquelas manobras que não alteram o equilíbrio de forças no sistema internacional.

${ }^{369}$ Quando ao final do jogo, a relação original (de paridade ou disparidade) entre os jogadores é alterada.

370 “O Plano Real, implementado na sua forma definitiva em julho de 1994, foi a tentativa que melhor obteve êxito, a exemplo do Plano de Conversibilidade argentino para a estabilização inflacionária da economia brasileira." TRICHES, Divanildo. Op. cit., p. 156.

371 "Todavia, essas questões e questionamentos são ainda mais importantes se levarmos em conta a assimetria econômica que há entre os parceiros; o baixo nível relativo de interdependência econômica existente; algumas questões relevantes ainda não resolvidas (...) e as múltiplas alternativas de inserção internacional apresentadas pelos parceiros, o que envolve a articulação de uma estratégia complexa de negociações comerciais conjuntas com os demais países e com os outros blocos econômicos.” PEÑA. Op Cit, p. 98.
} 
em conflito Argentina e Brasil no âmbito do bloco. Dos quatro primeiros, todos são relacionados a casos em que os dois países são partes.

\subsection{5 - O Fluxo Comercial no Mercosul Especialmente Centrado em Determinantes da Balança Comercial Brasil/Mercosul}

A integração regional, entendida como um mecanismo de alavancagem das atividades econômicas, baseada na eliminação de obstáculos ao comércio e à mobilidade de fatores, permite a ampliação da escala de produção, da competitividade e o aumento do fluxo de comércio intrabloco. Entretanto, provoca, ao mesmo tempo, desequilíbrios comerciais e de fluxo de capitais que podem ser entendidos como um elemento restritivo à mobilidade de bens e capitais, pois tendem a gerar insatisfação entre os sócios "prejudicados" e corroborar para entravar as discussões e o aprofundamento do processo integrador $^{372}$.

Especificamente, no Mercosul, como o movimento de capitais é ainda pouco significativo, o fluxo comercial é o principal componente do Balanço de Pagamentos intrabloco. Por isso, as discussões ficaram centralizadas nos determinantes do saldo da balança comercial demonstrando que o saldo comercial Brasil/Mercosul responde às mudanças no nível de renda interna e externa, aos termos de troca e à taxa de câmbio, de forma defasada.

Nesse aspecto, os termos de troca são apresentados de forma exógena, ou seja, não há um efetivo controle das autoridades econômicas, sendo pouco realista supor que os "formuladores de políticas" ${ }^{373}$ vão implementar políticas para controlar o nível de renda visando o equilíbrio comercial intrabloco.

Por sua vez, a integração no Mercosul gira em torno do comércio intra-regional, superdimensionando a importância que os fluxos de comércio têm nas relações entre os parceiros $^{374}$. Assim, os desequilíbrios gerados no comércio recíproco constituem um

\footnotetext{
372 “O período desde a assinatura do Tratado de Assunção corresponde a uma aceleração do processo de abertura comercial unilateral em relação a todos os países (em paralelo às concessões entre os parceiros), a momentos de internação de diversas crises no cenário internacional, a desequilíbrios nos preços relativos, a influxos extraordinários de investimento externo direto, à superposição entre as negociações sub-regionais e negociações ao nível hemisférico e multilateral, entre outros tantos determinantes." BAUMANN, Renato; MUSSI, Carlos. Mercosul: então e agora? LC/BRS/R.159, maio 2006, p. 2. Disponível em: <http://www. ciu.com.uy>. Acesso em: 24 nov. 2008.

373 "Policy makers".

374 “A extraordinária expansão do comércio entre os países do Mercosul, desde 1991, está muito mais ligada às preferências tarifárias acordadas do que à maior competitividade de suas empresas. Isso já pode ser observado nas comparações entre exportações/importações intra e extra-Mercosul.” MARTINS. Op. cit.
} 
obstáculo para o avanço do processo integrador, devido às medidas de correção que podem ser adotadas a curto prazo. Nesse sentido, serve de exemplo a obtenção pela Argentina, frente ao Brasil, em 2001, da permissão para zerar suas tarifas de bens de capital para nações de fora do bloco, prejudicando a indústria brasileira. É inútil saldar a flexibilidade do bloco e ao mesmo tempo ressaltar o caráter crucial da TEC. Torna-se mais distante o estabelecimento a médio prazo de uma moeda comum para o Mercosul quando cada país reafirma seu regime cambial ${ }^{375}$.

Nesse contexto, os arranjos cambiais e monetários adotados pelos países partes do Mercosul podem ser caracterizados como uma das assimetrias mais importantes de políticas macroeconômicas ${ }^{376}$. A manutenção das políticas cambiais do Brasil e da Argentina, ao afetarem a balança comercial, retarda o aprofundamento do processo de integração, pois levam os Estados Partes do Mercosul a buscarem alternativas para corrigirem os desequilíbrios, sendo que as medidas adotadas durante a vigência do Mercosul, em sua maioria, criaram mecanismos protecionistas, entravando relevantes discussões no sentido de se liberalizar o comércio entre eles.

No Mercosul existem enormes restrições ao avanço do processo de coordenação de políticas, em particular, à adoção da moeda única, demonstrando que, no curto prazo, não se pode esperar medidas significativas nessa direção. Observamos que a coordenação de políticas macroeconômicas deve fazer parte de um projeto de médio e longo prazo e a implementação de medidas visando equilibrar a balança comercial em função de desequilíbrios macroeconômicos, devem ocorrer de forma negociada, a fim de evitar choques, retaliações ou recuos na integração por parte dos demais parceiros.

A ironia é que se atualmente os principais instrumentos macroeconômicos estão sendo aplicados de forma similar nos Estados Partes (como taxa de câmbio livre, taxas de juros reais positivas para estimular a poupança interna e compromisso com a estabilidade dos preços por intermédio de metas de inflação), a convergência macroeconômica é agora mais dependente de como futuras reformas econômicas venham a ser implementadas nos Estados. O processo de integração pode contribuir de forma ativa para esse processo, seja como guia de padrões comuns ou pelo intercâmbio de experiências no processo de implementação ${ }^{377}$.

\footnotetext{
${ }^{375}$ Editoriais: Mercosul Congelado. Folha de São Paulo, São Paulo, 11 de outubro de 2001, Caderno A2.

${ }^{376}$ TRICHES. Op. cit., p. 162.

${ }^{377}$ BAUMANN e MUSSI. Op. cit, p. 6.
} 


\section{2 - A Tentativa de Integração}

A integração pode ser encarada como um laço de interdependência bastante expandido, no quadro de uma comunidade fortemente pluralista, ou como um laço muito estreito de interdependência, no quadro de uma comunidade que tende para a unificação ${ }^{378}$. De qualquer forma, segundo afirma GOMES, "é fruto do querer político dos Estados, em buscarem juntos, adotar políticas em conjunto, para enfrentarem os desafios do mundo globalizado",379.

Especificando, PEÑA assim escreve sobre a experiência de integração acumulada na construção do Mercosul:

Es una experiencia incipiente de un esfuerzo multinacional y multidimensional, que tiene como una de sus finalidades principales mejorar las condiciones de participación internacional real de sus países miembros en el escenario global y regional y, de tal forma, facilitar sus procesos de consolidación de la democracia, de cohesión y de transformación productiva ${ }^{380}$.

O Mercosul é a conseqüência de anos de tentativas bem intencionadas, mas pouco eficazes para conformar um espaço econômico integrado na região (pode-se afirmar, inclusive, que é resultado de uma fase de sub-regionalização). Afastadas as linhas mais rígidas dos grandes projetos do passado, os Estados Partes do Mercosul voltaram-se para um esquema mais gradual e flexível, com uma abordagem setorial e mais equilibrada dos principais eixos da integração.

Os cerca de dezoito anos do Mercosul representaram para os Estados Partes um período de transformações e volatilidade macroeconômica, com resultados relativamente decepcionantes face à expectativa de retomada do crescimento.

No entanto, ainda que se leve em consideração a abordagem setorial e flexível com que se deu a integração no Mercosul, bem como o atual estágio de integração do bloco ser menor do que o esperado para o presente momento quando da assinatura do

\footnotetext{
${ }^{378}$ BRAILLARD, Philippe. Teoria das Relações Internacionais. Lisboa: Fundação Calouste Gulbenkian, 1990 , p. 191.

379 GOMES. Op. cit., p. 57.

380 PEÑA, Félix. Instituciones y concertación de intereses nacionales: algunas reflexiones em torno a la experiência de los primeros quince años del Mercosur. In BASSO, Maristela (org.). Mercosul - Mercosur: estudos em homenagem a Fernando Henrique Cardoso. São Paulo: Atlas, 2007, p. 9.
} 
Tratado de Assunção, ainda assim, tem-se a possibilidade de incremento da integração existente através da agregação de novos elementos e estágios de interação entre os Estados Partes.

Visando a aprofundar os laços de integração que perfazem o Mercosul, especialmente no que concerne à moeda única, é interessante a observância do exemplo de integração européia e a tentativa de implemento de tal integração devidamente moldada às peculiaridades dos Estados Partes do Mercosul.

De acordo está PEÑA, ao justificar sua metodologia comparativa entre blocos para a abordagem do sul-americano, o que faz através, entre outros, do trecho a seguir transcrito, que expõe alguns dos pontos comuns a todo processo integracionista:

(...) se trata de procesos incrementales en los que participan países com diferencias - a veces pronunciadas - de poder relativo, de dimensión económica y de grados de desarrollo. Son procesos que solo pueden ser sustentables en el tiempo, precisamente si tienen éxito en desarrollar metodologias de trabajo conjunto, que permitan una administración razonable de fuerzas e intereses contradictorios entre sus países miembros y entre los diferentes sectores sociales que operan en su interior.

Nesse sentido, HEIKO WACKER ${ }^{381}$ afirma que a experiência européia pode servir de modelo para outras tentativas de integração em outras regiões, como na do Mercosul, uma vez adaptada à nova realidade. Ele ainda afirma ainda que, a partir de uma firme vontade política, baseada nos objetivos de integração e estabilidade, a decisão de criação de uma união monetária poderia gerar uma dinâmica por força da qual os países do bloco se aproximariam cada vez mais de uma "área monetária ótima".

Por fim, destaca o citado mestre, também, que, com $11,8 \%$ de participação no comércio global (ante $50,8 \%$ dos países da área do euro e $67,2 \%$ dos países da União Européia), os países do Mercosul (Argentina, Brasil, Paraguai e Uruguai), para a criação de uma moeda única, precisariam começar a formular uma agenda de medidas, dentre as quais dentre as quais estariam: o aprofundamento da integração comercial; a harmonização dos sistemas tributários; a finalização da união alfandegária; a criação de um verdadeiro mercado comum com livre circulação de bens, serviços e fatores produtivos; a

381 Resumo da palestra proferida, sob o título "Integração monetária: teoria e prática", pelo Dr. Heiko Wacker, no Centro Cultural Oboé, Fortaleza, em 5 de julho de 2005. Convidado pela Escola de Administração Fazendária (ESAF), órgão do Ministério da Fazenda, o Dr. Heiko Wacker é professor da Universidade de Colônia, Alemanha. 
convergência nominal; a cooperação macroeconômica; a credibilidade; e o alargamento do Mercosul para dar mais peso econômico ao bloco.

\section{3 - As Dificuldades Jurídicas a Superar}

A atual situação do Mercosul, com uma integração precária frente aos ideais inicialmente congregados quando da assinatura do TAs, tal como alhures exposto, decorre, além dos motivos já expostos, das dificuldades jurídicas, particularmente verificadas na não homogeneização das legislações constituições dos Estados-Membros.

Todo e qualquer avanço que se pretenda no processo de integração dos países do Mercosul deverá superar, manifestamente, os seguintes obstáculos: harmonia entre as leis; imprevisão constitucional da supranacionalidade; necessária manutenção da segurança jurídica. Em seguida, far-se-á uma análise mais pormenorizada de cada uma dessas barreiras.

\subsubsection{Harmonia entre as Leis}

A criação e desenvolvimento de um ambiente de integração e a inserção de um Estado e seu ordenamento jurídico nesse meio exigem adaptações que vão desde as constituições à legislação ordinária, até a divisão das competências legislativas e atribuição dos tribunais ${ }^{382}$.

O termo "harmonização legislativa" é encontrado no art. $1^{\circ}$, do TAs e no art. 25 do POP, in verbis:

Artigo $1^{\circ}$ do Tas - Os Estados Partes decidem constituir um Mercado Comum, que deverá estar estabelecido a 31 de dezembro de 1994, e que se denominará "Mercado Comum do Sul" (Mercosul).

Este Mercado Comum implica:

(...)

O compromisso dos Estados Partes de harmonizar suas legislações, nas áreas pertinentes, para lograr o fortalecimento do processo de integração.

Artigo 25 do POP - A Comissão Parlamentar Conjunta procurará acelerar os procedimentos internos correspondentes nos Estados Partes para a pronta entrada em vigor das normas emanadas dos órgãos do Mercosul previstos no Artigo $2^{\circ}$ deste Protocolo. Da mesma forma, coadjuvará na harmonização de legislações, tal como requerido pelo avanço do processo

${ }^{382}$ CASELLA, Paulo Borba. A integração econômica e seu tratado constitucional. In: Mercosul: desafios a vencer, vários autores. São Paulo: CBRI, 1994, p. 95. 
de integração. Quando necessário, o Conselho do Mercado Comum solicitará à Comissão Parlamentar Conjunta o exame de temas prioritários.

A harmonização legislativa a ser implementada é aquela que adapte as legislações internas a uma diretriz comum tomada externamente, podendo-se manter certas diferenças a despeito da atenuação e até eliminação de outras diferenças. O grande foco com a harmonização é propiciar uma aproximação das legislações de tal modo que realça suas similitudes e atenue suas diferenças.

Nesse sentido, apesar da previsão legal, ao utilizar as expressões "harmonizar suas legislações" e "harmonização de legislações", conforme consta, respectivamente, nos dispositivos legais expostos acima expostos, que impõe aos Estados |Partes a sua obrigatoriedade, tem-se que a harmonização legislativa presente no Mercosul destoa daquela existente em processos de integração mais complexos, tal como o verificado na União Européia.

A propósito, NEWTON DE LUCCA refere que "seria necessário que o Mercosul tivesse poderes normativos, vale dizer, poderes para legislar a respeito das matérias a ele afetos, com a edição de 'leis-modelo"” 383 .

No mesmo sentido, assevera que "mais do que mero acordo no plano das relações exteriores dos quatro países, capaz tão-somente de comprometer os respectivos governantes com a edição das normas de direito interno, o que efetivamente está em debate, de forma bastante concreta, é a possibilidade da edificação de um sistema de normas supranacional, voltado para a tutela legal do correspondente universo populacional. E a perspectiva de solidificação de tal sistema jurídico supranacional envolve, indiscutivelmente, explícita e implicitamente, a superação da competência normativa dos Estados Nacionais com relação às matérias que foram objeto de pactuação no âmbito do Mercosul” ${ }^{134}$.

Ao contrário da União Européia, em que as normas são dotadas de imperatividade sem necessidade de qualquer intermediação para a sua incorporação no ordenamento interno dos Estados-Membros, as normas emanadas do Mercosul não são dotadas de

\footnotetext{
${ }^{383}$ DE LUCCA, Newton. Processos comunitários de integração econômica e a proteção dos consumidores. Revista de Direito do Consumidor. São Paulo: Revista dos Tribunais, n 6, out./dez. 1995, p. 35.

${ }^{384}$ DALLARI, Pedro Bohomoletz de Abreu. O Mercosul perante o Sistema Constitucional Brasileiro. In: BASSO, Maristela (org.). Mercosul - Mercosur: Estudos em Homenagem a Fernando Henrique Cardoso. São Paulo: Ed. Atlas, 2007, p. 39.
} 
imperatividade e requerem determinados processos para sua obrigatoriedade no plano interno dos Estados Partes.

A unificação é entendida como o nível mais profundo de harmonização das legislações, através do estabelecimento de diretrizes equânimes para os Estados, com a sistematização normativa igualitária. A integração que objetive a unificação, por exemplo, monetária, exige a observância pormenorizada da possibilidade da harmonização como elemento de aproximação das legislações, adaptando-as a fatos e demandas concretas.

Podem-se destacar três princípios sobre a harmonização legislativa:

- definição de diretrizes comuns pelas legislações internas (nacionais);

- manutenção das peculiaridades de cada Estado;

- aperfeiçoamento constante dos instrumentos para minorar as diferenças existentes.

O caminho que se apresenta para a harmonização das leis é a operacionalização da harmonização jurídica básica, com a construção de um direito harmonizado aos processos de integração econômica, harmonia requerida para viabilizar a integração pensada para os Estados Partes do Mercosul. Com a harmonização legislativa suprimir-se-á ou atenuar-se-á as assimetrias entre as disposições legislativas internas na medida que se exija o funcionamento do mercado comum. Diante disso, o processo de harmonização legislativa do Mercosul, deve ser reavaliado, visando uma nova processualística que seja mais ágil e que atenda aos anseios e interesses de aprimoramento da integração entre os Estados Partes.

\subsubsection{A Imprevisão Constitucional da Supranacionalidade}

$\mathrm{Na}$ medida em que os Estados assumem compromissos mútuos por força de convenções internacionais, ocorre a diminuição paulatina do âmbito de competência discricionária de cada contratante ${ }^{385}$.

A supranacionalidade não é percebida no Mercosul ${ }^{386}$. Além disso, percebe-se que a constituição dos Estados Partes do bloco, tal como se encontram atualmente, dificultam a implementação da supranacionalidade em seu seio.

\footnotetext{
${ }^{385}$ RANGEL, Vicente Marotta. Os sujeitos de Direito Internacional. In: Direito Internacional Público. Rio de Janeiro: Escola de Guerra Naval, 1974, p. 12.

386 "No caso do Mercosul (...) não se pretende que as partes se integrem em uma nova soberania ou unidade autônoma de poder dentro do sistema internacional - ao menos não no atual estágio do respectivo processo nem num horizonte previsível. O panorama comum coexiste, portanto, com os diferentes panoramas nacionais, para o alcance de objetivos que são compartilhados. Todavia, diferente de uma união
} 
A Constituição da República Federativa do Brasil de 1988 (CF/88), por exemplo, não acolheu qualquer previsão quanto à supranacionalidade das normas do Mercosul. Além dessa omissão, há ainda certos entraves à sua instituição. Vale destacar e citar, no intuito de expor as dificuldades presentes na $\mathrm{CF} / 88$ à supranacionalidade, os art. $1^{\circ}$, I; art. $4^{\circ}, \mathrm{I}$; art. 49, I; e art. 102, III, b, tal como seguem:

Art. $1^{\circ}$ A República Federativa do Brasil, formada pela união indissolúvel dos Estados e Municípios e do Distrito Federal, constitui-se em Estado Democrático de Direito e tem como fundamentos:

I - a soberania;

Art. $4^{\circ}$ A República Federativa do Brasil rege-se nas suas relações internacionais pelos seguintes princípios:

I - independência nacional;

Art. 49. É da competência exclusiva do Congresso Nacional:

I - resolver definitivamente sobre tratados, acordos ou atos internacionais que acarretem encargos ou compromissos gravosos ao patrimônio nacional;

Art. 102. Compete ao Supremo Tribunal Federal, precipuamente, a guarda da Constituição, cabendo-lhe:

III - julgar, mediante recurso extraordinário, as causas decididas em única ou última instância, quando a decisão recorrida:

(...)

b) declarar a inconstitucionalidade de tratado ou lei federal;

Outro exemplo a ser destacado é o da Constituição da República Oriental do Uruguai que, em seu art. $6^{0387}$, refere-se apenas a uma integração social e econômica dos Estados latino-americanos relativos à defesa comum de seus produtos e matérias-primas ou para uma efetiva complementação de seus serviços públicos sem, destarte, fazer referência à supranacionalidade.

circunstancial perseguindo um objetivo comum, mas eventualmente transitório, a essência do fenômeno consiste em sua permanência, em sua vocação para ser uma parceria irreversível". PEÑA. Op. cit., p. 92.

387 “Artículo $6^{\circ}$.- En los tratados internacionales que celebre la República propondrá la cláusula de que todas las diferencias que surjan entre las partes contratantes, serán decididas por el arbitraje u otros medios pacíficos. La República procurará la integración social y económica de los Estados Latinoamericanos, especialmente en lo que se refiere a la defensa común de sus productos y materias primas. Asimismo, propenderá a la efectiva complementación de sus servicios públicos.” CONSTITUCIÓN DE LA REPÚBLICA. Disponível em: <http://www.parlamento.gub.uy/constituciones/const004.htm>. Acesso em: 25 nov. 2008. 
O Mercosul tem a sua produção normativa calcada no tradicional direito internacional. Diferença existente entre os Estados Partes do Mercosul e que merece ser apontada nesse momento a referente à dualidade ${ }^{388}$ nas relações Direito Interno — Direito Externo. Apesar de tanto o Brasil quanto a Argentina (esta última adota a dualidade de modo atenuado), por exemplo, serem adeptos do dualismo (que implica total distinção e independência entre o direito interno e o direito internacional), diferem no que tange ao tratamento conferido aos acordos internacionais. Enquanto na Argentina, o alcance e características das regras do Mercosul tomam uma importância maior à luz da reforma constitucional de $1994^{389}$, sendo que estas prevalecem em relação à norma interna ${ }^{390}$, no Brasil as normas internacionais têm vigência somente, após a devida processualística de nacionalização da norma, sendo então equiparadas, sob o aspecto da hierarquia das normas jurídicas, às leis internas ${ }^{391}$.

Frente ao que foi acima exposto, passa ao largo da atual realidade dos Estados Partes do Mercosul a possibilidade de implementação da supranacionalidade, no seio do bloco, tendo em vista as dificuldades jurídicas propiciadas pela imprevisão constitucional da supranacionalidade (tal como os exemplos citados transparecem) e mesmo de dispositivos implicitamente contrários a ela tal como exemplificado através de certos dispositivos da Constituição Federal do Brasil e da Constituição do Uruguai.

\footnotetext{
388 Para maior aprofundamento, com respeito a este assunto, inclusive a abordagem das teorias monista e dualista, veja-se YAMAMOTO, Toru. Direito Internacional e Direito Interno. São Paulo: Editora Sérgio Antônio Fabbris (SAFE), 2000.

389 "No plano jurídico, a reforma constitucional argentina de 1994, que positivou a supremacia do tratado em relação ao ordenamento jurídico interno, nos termos do inovador artigo 75 , incisos 22 e 24 , constitui formidável exemplo de superação dogmática, em que a hegemonia das idéias e a necessidade de abertura e inserção internacionais prevaleceram diante do anacrônico e insustentável isolamento jurídico." FONTOURA, Jorge. O Avanço Constitucional Argentino e o Mercosul. Revista de Informação Legislativa, Brasília, a. $37 \quad \mathrm{n}^{\circ} 146$ abr./jun. 2000, p. 56. Disponível em: $<$ http://www.senado.gov.br/web/cegraf/ril/Pdf/pdf_146/r146-04.pdf>. Acesso em: 24 nov. 2008.

390 "Ao Congresso também é conferida competência para aprovar os tratados de integração que deleguem competência e jurisdição a organizações supra-estatais em condições de reciprocidade e igualdade e que respeitem a ordem democrática e os direitos humanos (art. 75, 24). As normas destes tratados possuem hierarquia superior às leis. Assevere-se que a aprovação desses tratados de integração com países da América Latina necessita da maioria absoluta da totalidade dos membros de cada câmara legislativa; com as demais nações exige-se a maioria absoluta dos membros presentes de cada câmara para que, inicialmente, seja declarada a conveniência de aprovação do tratado e, depois de 120 dias, possa ser aprovado com o voto da maioria absoluta da totalidade de membros de cada câmara legislativa. A denúncia dos tratados objeto do citado art. 75,24 , também exige a maioria absoluta da totalidade dos membros de cada casa legislativa." BARBOSA, Salomão Almeida. As Relações Internacionais na Constituição da Argentina, Revista de Doutrina TRF $4^{a}$ Região, agosto de 2004. Disponível em: <http://www.revistadoutrina.trf4.jus.br >. Acesso em: 24 nov. 2008.

${ }^{391}$ DALLARI, Pedro Bohomoletz de Abreu. Op. cit., p. 43.
} 


\subsection{3 - A Necessária Continuidade da Segurança jurídica}

O princípio da segurança jurídica é geralmente classificado entre os princípios comuns aos direitos dos Estados, encontrando-se, inclusive, na própria base do Estado de Direito, ao lado do princípio da legalidade ${ }^{392}$.

A necessidade de certeza jurídica e de previsão não se limita ao interesse dos Estados Partes do Mercosul, incluindo também toda a comunidade, relacionada com os negócios, e que tem uma expectativa legítima sobre o relacionamento integrativo em apreço $^{393}$.

A segurança jurídica dos utilizadores de moeda constitui uma das prioridades fundamentais a serem trabalhadas ao pensar-se na possibilidade de implementação de uma moeda única no Mercosul.

A continuidade dos compromissos jurídicos, com a estabilidade das situações jurídicas passa pela existência de um aparato de medidas legais necessárias para garantir que as regras sejam cumpridas. Regras que se cumprem, por refletir uma negociação dinâmica de interesses recíprocos, contribuem para traduzir a relação integrativa em algo digno de crédito por parte dos cidadãos, investidores e demais Estados. Só assim um processo de integração pode ter eficácia política e econômica. É o que permite garantir um horizonte de previsibilidade para as decisões daqueles que operam no espaço integrado ${ }^{394}$.

A inexistência de uma adequada harmonização legislativa no Mercosul, somada a precária estrutura institucional e demais peculiaridades apresentadas no presente capítulo lançam dúvidas sobre a possibilidade de implementação de uma efetiva segurança jurídica caso o Mercosul adote a união monetária, valendo-se de seus atuais predicados, predominantemente marcados por deficiências e fragilidades, a despeito das inovações e tentativa de consolidação do princípio da segurança jurídica visado especialmente pelo Protocolo de Olivos ${ }^{395}$.

A união monetária, bem como toda e qualquer dinâmica de integração a ser implementada, deve ser efetivada garantindo-se a segurança jurídica, princípio tão valioso e de fundamental existência para a continuidade da caracterização dos Estados Partes do Mercosul como Estados de Direito.

\footnotetext{
${ }^{392}$ VENTURA, Deisy. Op.cit., p. 313.

${ }^{393}$ III H $3,3^{\circ}$ laudo arbitral.

${ }^{394}$ PEÑA. Op. cit., p.96.

${ }^{395}$ Protocolo de Olivos para a Solução de Controvérsias no Mercosul. Disponível em: $<$ http://www.mercosur.int >. Acesso em: 24 nov. 2008.
} 


\section{CAPÍTULO VII}

\section{PRESSUPOSTOS E CRITÉRIOS PARA A ADOÇÃO DE UMA MOEDA ÚNICA NO MERCOSUL}

Fenômeno recente, a globalização suscita novos desafios às ordens constituídas, gerando a necessidade de reverem-se alguns valores supremos tutelados pelo Direito, como se dá no caso da Soberania. RIBEIRO define globalização como "um fenômeno social, consistente na aproximação de distâncias geográficas e na homogeneização das expectativas de consumo, de práticas políticas decorrentes da globalização econômica"396 ${ }^{\text {. }}$

FREITAS JUNIOR, ao conceituar globalização econômica, complementa que essa “consiste na progressiva internacionalização dos mercados de bens, serviços e créditos, induzida pela redução de tarifas de exportação, de obstáculos aduaneiros e pela padronização das operações mercantis" ${ }^{\text {"397 }}$. Provocada pela competitividade internacional, entre outros fatores, leva à integração de países, acelerando o processo econômico no contexto mundial. Dentre essas integrações regionais encontram-se o Mercosul e a União Européia.

O Mercosul, entendido como processo complexo de construção progressiva de um espaço integrado de Estados, transcende as realizações políticas, econômicas e diplomáticas realizadas ao longo de seus aproximados dezoito anos de existência ${ }^{398}$. Tratase de uma realidade fortemente embasada no contexto histórico e político do subcontinente sul-americano, extravasando o simples conceito econômico de união aduaneira ou de mercado comum.

Em vista da amplitude de anseios e expectativas depositadas com a criação e desenvolvimento do Mercosul, bem como pela influência do exemplo europeu de ampla integração conquistada através da União Européia, a adoção de uma moeda única e o

\footnotetext{
${ }^{396}$ RIBEIRO, Maria de Fátima. Op. cit., p. 9-26.

${ }^{397}$ FREITAS JUNIOR, Antonio Rodrigues. Globalização, Mercosul e crise do Estado-Nação: perspectivas para o direito numa sociedade em mudança. São Paulo: LTr, 1997, p. 64.

${ }^{398}$ Vale lembrar que o Tratado de Assunção, tratado constitutivo do Mercosul, foi assinado em 26 de março de 1991.
} 
aprimoramento da integração atualmente existente entre os Estados Partes é temática atual e de grande repercussão nos mais diversos meios, a exemplo dos acadêmico e diplomático.

Segundo GIAMBIAGI e RIGOLON ${ }^{399}$, o Mercosul removeu barreiras que limitavam o comércio intra-regional, mas o aprofundamento do processo de integração parece requerer uma maior coordenação macroeconômica, sendo que a unificação monetária é uma alternativa de longo prazo para esse objetivo. Esse caminho proporcionaria uma maior credibilidade da política monetária, graças à criação de um banco central independente, a eliminação da incerteza cambial no interior da região e a redução dos custos de transação, o que incentivaria o crescimento do comércio e aumentaria a eficiência microeconômica.

Nesse aspecto, GAMBIAGI ${ }^{400}$ ainda destaca que "as condições para a vigência de uma moeda única deveria estar associada a um mercado único lato sensu, o que significa, entre outras coisas, que o mercado de trabalho composto pelo conjunto de áreas geográficas que tem a mesma moeda seja caracterizado pela mobilidade de fatores, de modo a evitar uma heterogeneidade das taxas de desemprego".

Um mercado fortalecido e em crescente integração requer, naturalmente, uma moeda única, pois que não faz sentido continuar com "barreiras" monetárias e cambiais em face da total liberalização de todos os demais tipos de fluxos de bens e serviços transfronteiriços e de intercâmbios transnacionais. Ainda que o grau de integração presente no Mercosul não seja suficiente para demandar de pronto uma moeda única, vale adentrar no estudo dos requisitos e critérios necessários para que uma moeda única realmente venha a ser implementada, a despeito da atual realidade do bloco.

A análise quanto à viabilidade de uma moeda única pelo Mercosul, ao longo desta pesquisa e, com maior profundidade, no presente capítulo, é fundamentada nos mesmos pressupostos e critérios que culminaram com a adoção da moeda única na União Européia. Contudo, eles não são, e nem podem ser, idênticos aos europeus, tendo em vista as particularidades e singularidades que a integração do Mercosul encerra.

Abordando a aplicabilidade da experiência européia à integração via Mercosul, LINS entende que:

${ }^{399}$ GIAMBIAGI, F.; RIGOLON, F. Áreas Monetárias Ótimas: Teoria, Unificação Monetária Européia e Aplicação para o Mercosul. BNDES, Ensaio BNDES, nº 8, 1998.

${ }_{400}$ GIAMBIAGI, Fábio. Mercosul: a unificação monetária faz sentido? Política Externa, Revista Paz e Terra, São Paulo, vol. 8, n 3, dez.jjan./fev. 2000, p. 34-35. 
Embora grande número de ressalvas quanto à aplicabilidade da experiência de integração monetária européia a outros grupos de países possa ser feito, o processo de preparação para a moeda única tem características específicas e uma trajetória de relativo sucesso que fazem da análise dos interesses para regiões que não a União Européia (UE), com características distintas e com diferente grau de maturidade econômica um tema relevante. A transposição desta experiência para grupos de países latino-americanos, como é evidente, não pode ser direta. No entanto, é possível, partindo de um estudo sobre a criação do Euro e da observação das instabilidades financeiras vividas pelos países emergentes nos últimos anos, refletir sobre a hipótese de que aspectos do processo de unificação monetária possam dar origem a uma proposta de orientação política e de política econômica passível de ser adaptada a outras realidades ${ }^{401}$.

A moeda única, cujo conceito foi criado e desenvolvido com a publicação de um artigo de MUNDELL ${ }^{402}$, em 1961, poderá vir a ser uma possibilidade real para o Mercosul, mas cujos pressupostos, critérios, vantagens e desvantagens devem ser sensivelmente ponderados quando da tomada de posição definitiva sobre sua adoção no seio do bloco.

\section{1 - Condições para a Implementação de uma Zona Monetária Ótima}

A análise dos processos de integração monetária toma por referência inicial a "teoria das áreas monetárias ótimas", desenvolvida a partir dos trabalhos pioneiros de MUNDELL ${ }^{403}$ (1961), MCKINNON (1963) ${ }^{404}$ e KENEN (1969) ${ }^{405}$.

Na década de 1960, MUNDELL formulou uma estrutura teórica de arranjo cambial ótimo que se tornou referência mundial. Ele rejeitou a idéia de flexibilidade da taxa de câmbio como instrumento eficiente para estabilizar os desequilíbrios de uma economia e centralizou as atenções em um regime cambial no qual dois (ou mais) Estados

401 LINS, Maria Antonieta. Ganhos de Estabilidade Financeira como Resultado de Coordenação Macroeconômica e Cooperação Monetária: pensando no Mercosul à Luz da Experiência Européia. Anais do XXXI Encontro Nacional de Economia. $<$ http://www.anpec.org.br/encontro2003/artigos/C51.pdf >. Acesso em: 14 dez. 2008, p. 2.

${ }^{402}$ MUNDELL, R. A Theory of Optimum Currency Areas. American Economic Review, set. 1961, p. 657665.

403 Robert Mundell Prêmio Nobel de Economia em 1999, devido à "Teoria das Zonas Monetárias Ótimas", que estabelece as condições para a adoção de uma moeda comum para uma zona geográfica, o professor Mundell é considerado o "pai do euro". Defensor do conceito de moeda única, ele vai além, e sugere a criação e adoção de uma única moeda para todo o planeta.

${ }^{404}$ MCKINNON, R. Optimum Currency Areas. American Economic Review, set. 1963, p. 717-725.

${ }^{405}$ KENEN, P. The Theory of Optimum Currency Areas: An Ecletic View. Mundell \& Swoboda, Monetary Problems of the International Evidence, Discussion Paper 2295. Londres: Centre for Economic Policy Research, 1969, p. 41-60. 
fixam a taxa de câmbio entre eles como condição para manter a estabilidade dos preços relativos e promover a integração da região ${ }^{406}$.

MUNDELL escreve que um país teria, dentre outros, os seguintes motivos para não participar da união monetária: (i) a inflação preferida pelo país é diferente da inflação da área monetária; (ii) o país prefere usar a taxa de câmbio como instrumento para afetar o emprego, os salários reais e o balanço de pagamentos; e (iii) o país deseja usar a expansão monetária ou o imposto inflacionário para financiar os gastos públicos. E acrescenta que, simultaneamente, o mesmo país teria os seguintes motivos para participar de uma união monetária: (a) a inflação da união monetária será mais baixa; (b) os custos de transação serão reduzidos; (c) a paridade do poder de compra com os parceiros da união monetária será mantido; (d) o poder discricionário das autoridades monetárias e fiscais será acentuado; (e) a incerteza cambial será reduzida; (f) os efeitos de choques serão distribuídos pelos participantes da união monetária; (g) a integração regional será intensificada; (h) o poder político, econômico e estratégico da região aumentará; e (i) as políticas monetária e fiscal domésticas serão disciplinadas pela política monetária da união $^{407}$.

Uma área monetária é entendida como um conjunto de Estados ou regiões dentro do qual as taxas de câmbio são fixas. Há uma dependência da cooperação entre vários bancos centrais ou da existência de um único banco central, cuja ação deve levar em conta a evolução do lado real da economia dos países e regiões que compõem a área monetária $^{408}$. Já a área monetária ótima é a região definida por uma grande mobilidade interna de fatores e uma pequena mobilidade externa dos mesmos e, também, por espaço geográfico apropriado para a existência de uma moeda única.

Partindo do entendimento de uma área monetária, em especial do que vem a ser tal área "ótima", deve-se entender que essa, para ser implementada com uma moeda única requer o cumprimento de algumas condições.

$\mathrm{Na}$ experiência européia de integração, a doutrina elenca algumas condições requeridas para a implementação da moeda única e a criação de uma área monetária ótima, sendo exemplos ${ }^{409}$ : o aprofundamento dos vínculos comerciais e financeiros dos países que

\footnotetext{
${ }^{406}$ LINS, Maria Antonieta. Op. cit., p. 8.

${ }^{407}$ MUNDELL, R. A. Op. cit., p. 657-665.

${ }^{408}$ LINS, Maria Antonieta. Op. cit., p. 2.

${ }^{409}$ Para maiores informações sobre os condicionantes no âmbito de integração européia, consultar: ROSE, A.; ENGEL, Charles. Currency unions and international integration", Journal of Money, Credit and Banking, vol. 34, nº 4, nov. 2002, p. 1.067-1.089.
} 
compõem o "bloco" a ser unificado; a mobilidade de fatores entre as economias; o grau de convergência entre o ciclo econômico desses países; a construção de uma base institucional adequada, com uniformização das políticas fiscal, monetária etc., e ambiente negocial com distorções minimizadas; a existência de "lideranças regionais" aptas e dispostas a pagar o preço da "unificação". Nesse sentido, Frankel e Rose argumentam que a "as estruturas das economias mudam substancialmente com seu ingresso numa união monetária" ${ }^{410}$. As nações altamente integradas no comércio internacional são as que apresentariam melhores características para constituir uma área monetária ótima.

Para KRUGMAN e OBSTFELD, os ganhos de uma eficiência monetária, obtidos através da área monetária ótima, estariam diretamente relacionados com o grau de integração: "quanto maior o grau de integração entre os países (quanto mais alto for o percentual do PIB transacionado externamente) com taxa de câmbio fixa, maiores serão os ganhos de eficiência monetária" ${ }^{\text {,411. }}$.

Na União Européia ${ }^{412}$, entendem-se como critérios de convergência para a união monetária: convergência da taxa de juros; convergência fiscal e orçamentária; estabilidade de preços; convergência da variação cambial.

Ao tomar o exemplo europeu como referência, deve-se lembrar que a integração, especialmente no que se refere à criação de uma moeda única, é um imperativo político que transcende ao preenchimento estrito de critérios econômicos previamente alcançados, como sugere a teoria das áreas monetárias ótimas. Ainda assim, tem-se que, quanto mais um grupo de economias se afasta dos critérios "ótimos", mais difícil tende a ser o esforço de aprofundamento da integração ${ }^{413}$.

Notório é, a partir do exemplo europeu, que a união monetária é um estágio superior ao do mercado comum, somente implementável quando exista a consolidação de um conjunto de fatores no bloco capazes de viabilizar, com maturidade, o desenvolvimento da integração de seus Estados-Membros. Assim, adotar pressupostos para a união monetária, mais que mera formalização do processo de aprofundamento da integração

\footnotetext{
${ }^{410}$ TRICHES, Divanildo. Op. cit., p. 45.

411 TRICHES. Op. cit., p. 47.

412 Os critérios estão especificados no Protocolo $\left(n^{\circ} 21\right)$ relativo aos critérios de convergência a que se refere o artigo 121 do Tratado que institui a União Européia.

${ }^{413}$ Neste sentido, para maiores informações sobre a dinâmica de coordenação de políticas, especialmente no âmbito macroeconômico, consultar COOPER, Richard N. Economic interdependence and coordination of economic policies. R. W. Jones \& P. B. Kenen (ed.) Handbook of International Economics, , chapter 23, 1985, p. 1.195-1.234; e CURRIE, David, and others. International cooperation and reputation in an empirical two-bloc model. Ralph C. Bryant and Richard Portes, eds., Global Macroeconomics: policy conflict and cooperation. London: Macmillan, 1987.
} 
entre os Estados, caracteriza-se como requisito fundamental para que tal integração tenha condições de ser implementada e possua estabilidade e harmonia para ser duradoura.

No âmbito do Mercosul, a adoção de uma moeda única está condicionada às seguintes condições, dentre outras ${ }^{414}$ : harmonização das políticas macroeconômicas; não desvalorização pelos Estados de suas taxas de câmbio, que devem ser mantidas dentro de uma margem normal determinada; manutenção da taxa anual de inflação dos Estados em nível inferior a 3,0\%; inexistência de excessivos déficits fiscais nos Estados Partes; a dívida líquida pública de um Estado Parte não exceder 40,0\% do PIB; os Estados não apresentarem uma relação transações correntes/PIB acima de 3,0\%. Analisando especificamente o documento pertinente aos critérios de convergência macroeconômica, aprovado em dezembro de 2000 pelos presidentes do Mercosul durante o encontro regional anual do Mercosul, percebe-se que esse enfatiza que se os países, em um determinado ano, incorrerem em desvios em relação aos critérios pré-estabelecidos, então eles terão que adotar medidas corretivas para alcançar os critérios de convergência macroeconômica.

No que concerne à tomada de decisão sobre a implementação de uma moeda única no Mercosul, se faz de suma importância relevar-se a influência das relações comerciais nacionais e internacionais, atualmente consolidadas em grandes espaços econômicos. Ambas as formas básicas ${ }^{415}$ de teoria de área monetária ótima (tanto a que enfatiza ajustes automáticos de equilíbrio interno e externo, quanto a que defende o ajuste através da intervenção governamental por meio das políticas monetárias) têm como objetivo reduzir incertezas e instabilidades com relação à variabilidade que abrange as relações comerciais, estabelecendo uma margem segura para expectativas e reduzindo os custos de transação.

Assim, a ampliação das dimensões dos mercados nacionais é requisito fundamental para êxito do desenvolvimento econômico de cada Estado.

Os resultados dos estudos empíricos ${ }^{416}$ realizados sobre a integração econômica mostram que há efeitos positivos nas expectativas do setor real das economias envolvidas no processo. De acordo com as pesquisas, as relações comerciais influenciam a integração econômica quando reagem significativamente à eliminação do risco cambial - que dá maior previsibilidade para o acesso do mercado mundial - e ao aumento do volume de recursos financeiros - que proporciona melhores métodos para produção em grande escala

\footnotetext{
${ }^{414}$ GIAMBIAGI, Fábio. A Moeda Comum como Base do Crescimento do Brasil e da Argentina. Revista do Bndes, Rio de Janeiro, vol. 8, no 16, p. 119-166, dez. 2001, p. 129-130.

${ }^{415}$ TRICHES, Divanildo. Op. cit., p. 42.

416 TRICHES, Divanildo. Op. cit., p. 49.
} 
e, conseqüentemente, a redução dos custos dos bens finais ${ }^{417}$. A competitividade e a maior participação no mercado externo, resultados dos dois fatores anteriormente relacionados, tornam possível a expansão da economia e do bem-estar social.

As relações comerciais que caracterizam o mercado comum se estabelecem por tipos de liberdade: a livre circulação de mercadorias, a liberdade de estabelecimentos, a livre circulação de trabalhadores, a livre circulação de capitais e a liberdade de concorrência - todas essas liberdades, por exemplo, estão asseguradas no Direito Comunitário europeu $^{418}$. Considerando a moeda única como uma ferramenta para que essas liberdades possam atuar aliadas a melhor dinâmica e surgimento de novas oportunidades, pode-se concluir que as relações comerciais influenciam positivamente na unificação monetária no intento de efetivá-las, como pretendido no mercado comum.

Contudo, como já comentado anteriormente, para que haja a adoção da moeda única é preciso o cumprimento de diversas condições, cuja ausência faz com que ela, ao invés de fortalecer o bloco econômico, conduza-o à fragilidade e ao insucesso. É nesse sentido que GOMES argumenta que a união monetária não iria necessariamente conferir estabilidade econômica perante a comunidade internacional:

\begin{abstract}
A união monetária num mercado comum consolidado traz inquestionavelmente benefícios aos Estados, possibilitando maior estabilidade econômica e a livre circulação dos fatores de produção. Todavia, o exemplo europeu, em que os Estados-membros têm maior desenvolvimento que os países do Mercosul, não lhe serve como referencial e certeza de sucesso, posto que as realidades são distintas. Ali, o processo iniciou-se a concretizar-se em fins de 1992, com a instituição do Tratado de Maastrich, e somente iria consolidar-se dez anos depois; mesmo assim, está sendo marcado por dúvidas entre os paises associados quanto ao sucesso da união monetária, não obstante o sucesso da integração econômica estar presente em relação à valorização da moeda européia frente ao dólar ${ }^{419}$.
\end{abstract}

Para o autor supracitado, o Mercosul encontra-se em fase intermediária de integração, visto não existirem condições para a implantação de moeda única no bloco ação essa que caracterizaria etapa final do processo de integração. Luis Felipe Lampreia, ex-Ministro das Relações Exteriores do Brasil, expõem o mesmo entendimento ao afirmar

\footnotetext{
${ }^{417}$ TRICHES, Divanildo. Op. cit., p. 49.

418 SABBATO, Luiz Roberto. O Mercosul e o Direito comunitário. Revista de Derecho del Mercosur, n²Buenos Aires : La Ley, 1999.

${ }^{419}$ GOMES, Eduardo Biacchi. Blocos econômicos e a solução de controvérsias. 2. ed. 4. reimp. Curitiba: Juruá, 2008, p. 59-60.
} 
que "Não se pode colocar temas como a moeda única ou integração da legislação trabalhista, sem que hajam outras etapas anteriormente" ${ }^{420}$.

Vale ressaltar ainda as assertivas de GIAMBIAGI, que também escreve sobre a questão. Entre as várias críticas que faz à criação de uma moeda única no Mercosul, uma é quanto a este não ser momento adequado para sua implantação. Conforme seus estudos, a moeda única deve ser entendida como uma meta a ser alcançada somente após a concretização de uma maior integração dos países, com a extinção das listas de exceção no que tange à Tarifa Externa Comum; a harmonização das leis trabalhistas, tributárias e referentes ao mercado de capitais, bem como a integração dos sistemas financeiros dos membros do bloco ${ }^{421}$.

Sobre os mecanismos de convergência macroeconômica no Mercosul, os Presidentes dos Estados Partes do Mercosul, Bolívia e Chile reunidos em Florianópolis em 15 de dezembro de $2000^{422}$. Com tal intenção, explicitaram metas comuns e mecanismos de convergência, sendo eles: a definição da variável de fluxo fiscal; a definição da variável fiscal de estoque; o controle da inflação. Além disso, definiram medidas corretivas que incluíam os seguintes pontos: projeção macroeconômica para o período de retorno às metas; medidas de política macroeconômica; medidas estruturais, quando for o caso.

Visando o preenchimento das condições anteriormente mencionadas, há que se dar especial atenção à existência dos seguintes pontos: harmonização das legislações nacionais; exercício temporário de um sistema de taxas cambiais com limites de oscilação; criação de um banco central único.

\subsubsection{Harmonização das Legislações Nacionais - Direito Comparado no Mercosul}

Com efeito, cumpre referir que o Mercado Comum deve ditar a legislação que ordenará as relações dentro de seus domínios. Deve-se ter em conta, para efeito da legislação do Mercosul, que ela deve constituir uma legislação autônoma, valendo por si mesma para regular as relações jurídicas no seio do bloco. Além disso, e passo importante

\footnotetext{
${ }^{420}$ LAMPREIA, Luis Felipe apud ALISKI, Ayr. É cedo para o Mercosul ter moeda única. Zero Hora. Porto Alegre, 31 ago. 1998, p. 20.

${ }^{421}$ GIAMBIAGI, Fabio. Moeda única do Mercosul. Revista Brasileira de Política Internacional. Brasília: Instituto Brasileiro de Relações Internacionais, 41 (1), 1998, p. 25.

422 Disponível em: <http://gmm.mecon.gov.ar/pdf/declaracion_presidencial_metas-dic2000(por).pdf $>$. Acesso em: 14 dez. 2008.
} 
para que as normas do Mercosul tenham fortalecimento de sua aplicabilidade, faz-se necessária a harmonização das legislações nacionais, em especial no que se refere aos aspectos econômicos e monetários.

A harmonização é, pois, o "instrumento apto para a realização da integração no mercado" 423 - em comparação com o conceito da uniformização, o qual sugere uma forma distinta para a integração, discussão essa já superada em relação aos debates dos anos 60 e 70. No que diz respeito ao Direito Público, a harmonização das legislações deve ser desenvolvida depois da implementação das provisões legislativas formadas nos demais tratados entre os Estados Partes, a fim de que se possam observar, no âmbito do Direito Público, e manifestamente no Direito Constitucional, toda a carga política e a marca de valores nacionais inerentes às peculiaridades de cada um dos países ${ }^{424}$.

Observam SILVA NETO e MELO que "uma das conseqüências diretas e inevitáveis, decorrente desse processo de integração, é o aumento das relações jurídicas, e, por conseqüência, o aumento dos conflitos de interesses entre entes dos diferentes países", de modo que esse aumento "demanda soluções novas e rápidas, pois a complexidade das relações internacionais não se presta a soluções morosas" ${ }^{, 425}$.

Aqui, mais que a mera dedução da necessidade de existência de uma regulação e um órgão de solução de conflitos no seio do Mercosul (o que já existe), pretende-se especificamente apontar a necessidade de que os conflitos sejam prevenidos, sempre que possível, em momentos anteriores à ocorrência do conflito em si, particularmente através da harmonização legislativa dos Estados Partes do Mercosul, harmonização esta tão necessária e que pode, sensivelmente, dinamizar as relações intrablocos pela maior perfectibilidade do desenvolvimento das mesmas em face de um ordenamento jurídico "melhor estruturado".

Vale trazer para o âmbito das normas do Mercosul o pensamento de PEROTTI a respeito da autonomia das normas comunitárias, em que o referido autor manifesta que é exatamente a autonomia destas que vai levar a diferenciação em relação ao direito interno dos Estados. E que nisso, o principal problema legislativo está na coordenação da

${ }^{423}$ FRADERA, Véra M. Jacob. Harmonização do Direito Público (constitucional) no Âmbito do Mercosul. Revista da Escola Superior da Magistratura do Estado de Santa Catarina, 1998, p. 248.

${ }^{424}$ Ibidem, p. 248-247.

425 SILVA NETO, O.C; MELO, S.S. Solução de Controvérsias do Mercosul. RODRIGUES, Horácio Wanderlei ( Coord.) , Cap. IV - "considerações sobre a cooperação jurisdicional no âmbito do Mercosul", 1997 , p. 82. 
legislação interna com a normativa comunitária, bem como a forma como se dá a recepção da legislação comunitária pelas legislações internas ${ }^{426}$.

Levando-se em consideração que a harmonização da legislação dos Estados Partes do Mercosul visa o aumento da efetividade e legitimidade das leis emanadas pelas instituições que o compõe, faz-se importante estar sensível às palavras de PEÑA no que concerne à efetividade e legitimidade das normas em um processo de integração entre Estados:

O grande desafio deste tipo de processo é, precisamente, manter ao longo do tempo o quadro de "ganha-ganha" que sustenta o vínculo associativo. Não há espaço para jogos do tipo "soma-zero". E a experiência histórica - bastante incipiente neste tipo de fenômeno - revela que para tanto é fundamental que todo o processo seja orientado por regras e por instituições jurisdicionais que assegurem sua vigência. Trata-se, seguindo a conhecida distinção apresentada dentre outros, pelo professor John Jackson, do princípio de relações "rule-oriented", isto é, de relações de integração - comerciais internacionais multilaterais, no caso da OMC -, orientadas por regras efetivas - que penetram na realidade - e legítimas com esteio social nos respectivos países -, oposto ao princípio "poweroriented", ou seja, de relações orientadas pelo poder do mais forte. A diferença é essencial na ora de dirimir conflitos entre os parceiros.

Só assim, um processo de integração pode ter eficácia política e econômica, ou seja, só assim, pode alcançar os objetivos que conduziram ao vínculo associativo ${ }^{427}$.

Relativamente à interface do Tratado de Assunção e do Mercosul com o sistema constitucional brasileiro, DALLARI ${ }^{428}$ afirma o seguinte:

a) o Tratado de Assunção, bem como os Protocolos que lhe são adicionais, em que pese a diretriz constitucional de estímulo à integração latino-americana, se equiparam, do ponto de vista jurídico, à generalidade dos tratados internacionais, tendo seu conteúdo, por decorrência de entendimento jurisprudencial, força equivalente à das leis, por elas podendo ser modificado;

b) não há equacionamento constitucional claro para a definição acerca da cogência, inclusive face à eventual oposição no âmbito do ordenamento jurídico interno, das decisões emanadas das instâncias deliberativas componentes da estrutura do Mercosul.

\footnotetext{
${ }^{426}$ PEROTTI, Alejandro D. La Supranacionalidad desde la óptica del Derecho Constitucional de los Estados Partes del Mercosur: el caso Brasil. Revista de Derecho del MERCOSUR, nº 6, dic. 1998, p. 59

${ }^{427}$ PEÑA, Félix. Direito e Instituições no Mercosul: um balanço de conquistas e insuficiências. In: Mercosul e União Européia: perspectivas da integração regional. Rio de Janeiro: Lumen Juris, 2006, p. 95-96.

${ }^{428}$ DALLARI, Pedro Bohomoletz de Abreu. Op. cit., p. 36.
} 
E conclui DALLARI ${ }^{429}$ aduzindo que "tal situação, certamente causadora de frustração para os adeptos de um processo integracionista mais acelerado, deriva de características próprias do desenvolvimento histórico das instituições políticas brasileiras, o qual tendeu sempre para a consagração de um cenário eminentemente autárquico e formalmente pouco permeável a veleidades internacionalistas".

Analisando-se o sistema constitucional dos países integrantes e em fase de integração ao Mercosul, verificam-se algumas inconsistências e incompatibilidades com o processo de integração, o que demandaria imprescindível reforma constitucional nesse aspecto.

No caso do Brasil, conquanto a Constituição da República Federativa do Brasil não delimite expressamente o processo de internalização dos tratados internacionais, a norma aponta para uma prática reiterada, condicionando-a à declaração positiva de duas vontades: (i) a do Presidente da República para celebrar o tratado, nos termos do artigo 84, incisos VII e VIII; e (ii) a do Congresso Nacional para resolver definitivamente em relação aos tratados, consoante dispõe o artigo 49 , inciso I.

Por outro lado, é possível afirmar que a incorporação das normas de Direito Derivado deve-se dar automaticamente, uma vez que o artigo $4^{\circ}$, parágrafo único, da Constituição Federal, estabelece o seguinte:

Parágrafo único. A República Federativa do Brasil buscará a integração econômica, política, social e cultural dos povos da América Latina, visando à formação de uma comunidade latino-americana de nações.

Nesse sentido, poder-se-ia firmar o entendimento de que quando da constituição do Mercosul, ocorreu a transferência das competências mínimas necessárias à implementação de um processo de integração, bem como para a concretização da descrita “comunidade latino-americana de nações".

Dentre as competências transferidas ao processo de integração regional responsável pelo estabelecimento pelo Mercosul, estaria a capacidade de criar normas obrigatórias para os Estados Partes, porquanto o entrave burocrático para sua aprovação, como é promovido para as normas de Direito Internacional Público Clássico, acabaria por inviabilizar o processo de integração do bloco.

${ }^{429}$ DALLARI, Pedro Bohomoletz de Abreu. Op. cit., p. 37. 
Ademais, não existe qualquer norma no ordenamento jurídico brasileiro apontando qual órgão, ou Poder, é responsável por executar um procedimento de internalização das normas de Direito Internacional do Mercosul, nem a descrição de um procedimento propriamente dito, contrariando qualquer esforço ou incentivo à formação da desejada comunidade.

Por sua vez, o Uruguai tem o mesmo entrave legislativo-constitucional que o Brasil, conforme aponta $\mathrm{FLOH}^{430}$, nos termos do disposto no art. $6^{\circ}$ da sua Constituição Federal:

Artículo $6^{\circ}$.- En los tratados internacionales que celebre la República propondrá la cláusula de que todas las diferencias que surjan entre las partes contratantes, serán decididas por el arbitraje u otros medios pacíficos. La República procurará la integración social y económica de los Estados Latinoamericanos, especialmente en lo que se refiere a la defensa común de sus productos y matérias primas. Asimismo, propenderá a la efectiva complementación de sus servicios públicos.

Diversamente, na Argentina o processo regional de integração recebe, por delegação, a capacidade de editar normas com hierarquia superior às leis ordinárias, apresentando apenas condições para a aprovação do tratado constitutivo, sem qualquer óbice ao desenvolvimento do Direito Derivado, conforme estabelece os art. 75, item 24, da Carta Constitucional Argentina:

Artículo 75 - Corresponde al Congreso:

(...)

24. Aprobar tratados de integración que deleguen competencia y jurisdicción a organizaciones supraestatales en condiciones de reciprocidad e igualdad, y que respeten el orden democrático y los derechos humanos. Las normas dictadas en su consecuencia tienen jerarquía superior a las leyes.

La aprobación de estos tratados con estados de Latinoamérica requerirá la mayoría absoluta de la totalidad de los miembros de cada Cámara. En el caso de tratados con otros estados, el Congreso de la Nación, con la mayoría absoluta de los miembros de cada Cámara, declarará la conveniencia de la aprobación del tratado y sólo podrá ser aprobado con el voto de la mayoría absoluta de la totalidad de los miembros de cada Cámara, después de ciento veinte días del acto declarativo.

La denuncia de los tratados referidos a este inciso, exigirá la previa aprobación de la mayoría absoluta de la totalidad de los miembros de cada Cámara.

${ }^{430}$ FLOH, Fabio. Op. cit., p. 263. 
Cumpre observar que conquanto a Carta Constitucional argentina tenha sido promulgada em 1853, as normas que se encontram em vigor resultam de reforma constitucional realizada em 1994. Essa reforma visou também a inserção de “"institutos para la integración y jerarquía de los tratados internacionales', que viriam a ser previstos por meio da incorporação de novos incisos ao artigo da Constituição voltado ao arrolamento das atribuições do Congresso" ${ }^{431}$.

Na linha do sistema constitucional argentino, a Constituição do Paraguai de 1992 reflete a tendência a uma maior integração internacional "acentuada regionalmente com o advento do Mercosul, cujo tratado inaugural foi assinado em março do ano anterior a promulgação do novo texto constitucional justamente na capital guarani" ${ }^{432}$, estabelecendo no artigo 145 da Carta Constitucional o seguinte:

Artículo 145. Del Orden Jurídico Supranacional. La República del Paraguay, en condiciones de igualdad con otros Estados, admite un orden jurídico supranacional que garantice la vigencia de los derechos humanos, de la paz, de la justicia, de la cooperación y del desarrollo, en los político, económico, social y cultural.

Dichas decisiones sólo podrán adoptarse por mayoría absoluta de cada Cámara del Congreso.

Finalmente, a Venezuela, que está em processo de integração ao bloco comum, a partir do Protocolo de Adesão da República Bolivariana da Venezuela ao Mercosul, prevê no art. 153 da sua Carta Magna, uma flexibilização no processo de internalização das normas do Direito Derivado que visam à integração e união entre os países da América Latina e do Caribe, nos termos que seguem:

"Artículo 153. La República promoverá y favorecerá la integración
latinoamericana y caribeña, en áreas de avanzar hacia la creación de una
comunidad de naciones, defendiendo los intereses económicos, sociales,
culturales, políticos y ambientales de la región.
(...)
Para estos fines, la República podrá atribuir a organizaciones
supranacionales, mediante tratados, el ejercicio de las competencias
necesarias para llevar a cabo estos procesos de integración. Dentro de las
políticas de integración y unión con Latinoamérica y el Caribe, la

${ }^{431}$ DALLARI, Pedro Bohomoletz de Abreu.. Constituição e tratados internacionais. São Paulo: Saraiva, 2003, p. 35-36.

${ }^{432}$ Ibidem, p. 38. 
República privilegiará relaciones con Iberoamérica, procurando sea una política común de toda nuestra América Latina. Las normas que se adopten en el marco de los acuerdos de integración serán consideradas parte integrante del ordenamiento legal vigente y de aplicación directa y preferente a la legislación interna."

Nesse aspecto, constata-se a autorização formal para a transferência de competência legislativa do Estado da Venezuela para uma organização regional latinoamericana, havendo a transposição do elemento internacional para o elemento supranacional.

Ainda que se possam interpretar as obscuridades verificadas nas Constituições Federais brasileira e uruguaia como autorização implícita para a construção de um ordenamento jurídico comunitário no Mercosul, suas disposições não delegam expressamente poderes legislativos a uma organização internacional de integração, instituindo normas e procedimentos comumente utilizados para a elaboração do Direito Internacional Público Clássico.

Desse modo, diante das normas constitucionais dos países componentes do Mercosul e da Venezuela, anteriormente transcritas, constata-se que ainda se reputa imprescindível o estabelecimento de um procedimento claro de internalização das normas de Direito Derivado relativas ao processo de integração dos Estados-Partes do Mercosul, a fim de se evitar entraves e questionamentos jurídicos que inviabilizariam o processo de harmonização legislativa, fim último do Direito Derivado do Mercosul.

Portanto, resta evidenciado que o fortalecimento jurídico do Mercosul, principalmente no que concerne à imprescindível harmonização das legislações dos Estados Partes, é questão prioritária que deve ser necessariamente sanada e adaptada, a fim de que se possa cogitar na implementação de uma união monetária eficaz.

\subsubsection{Exercício Temporário de um Sistema de Taxas Cambiais com Limites de Oscilação}

O exercício temporário de um sistema de taxas cambiais com limite de oscilação apresenta-se como condição prévia necessária e constitui indispensável instrumento se for admitida como possível a implementação da União monetária no Mercosul. 
Os resultados e a eficácia de uma regra cambial dependem do contexto político e econômico em que tal regra é inserida. Nas experiências díspares de diferentes Estados, a regra é respeitada quando concomitante a condições específicas, internas e internacionais, adequadas. Nesse sentido, a maturidade econômica e o desenvolvimento propiciaram o suporte necessário para a efetividade do regramento cambial a ser estabelecido, ao criarem um círculo de interesses que beneficiam a estabilidade monetária ${ }^{433}$.

O histórico da integração monetária européia é exemplo significativo para considerar-se antes de uma tomada de decisão definitiva sobre a possibilidade de exercício temporário de um sistema de taxas cambiais com limite de oscilação. O exemplo a ser destacado, que remonta ao início da década de 1970, notoriamente bem antes da constituição da União Européia, é interessante porque expõe como tal medida, quando adotada por um conjunto de Estados, pode resultar em fracasso, ainda que tenha sido criada com fim maior, tal como a preparação para a implementação de uma união monetária.

O exemplo europeu aqui em comento é o da criação da "serpente do túnel" em março de 1972. O contexto da adoção de tal iniciativa foi que o colapso do sistema de Bretton Woods e a decisão americana de permitir a flutuação do dólar em agosto de 1971 provocaram uma onda de instabilidade nos mercados cambiais que pôs profundamente em causa as paridades entre as moedas européias ${ }^{434}$.

A Alemanha, a Bélgica, a França, a Itália, o Luxemburgo e a Holanda (em conjunto denominados de "os Seis"), buscando "dar um passo a frente" nos esforços visando à integração monetária, criaram a "serpente no túnel", mecanismo de flutuação concertada das moedas (a serpente) no interior de margens de flutuação estreitas em relação ao dólar (o túnel). O exemplo é considerado interessante de ser trazido para efeito de influenciar a tomada de iniciativa semelhante no âmbito do Mercosul, pois, apesar de a iniciativa ser dotada de interesse integracionista louvável, em menos de dois anos após sua criação, a "serpente", desestabilizada pelas crises petrolíferas, pela debilidade do dólar e pelas divergências entre as políticas econômicas, perdeu a maior parte dos seus membros para finalmente ficar reduzida a uma zona do "marco" reagrupando a Alemanha, o Benelux e a Dinamarca.

A despeito do fracasso da referida medida, tem-se que a possibilidade de tal implementação no seio do Mercosul é plausível frente à realidade de seus Estados Partes.

\footnotetext{
${ }^{433}$ MACEDO, Jorge. Portugal e a união monetária européia. Análise Social, vol. XXXI, (138), 1996, p. 901.

${ }^{434}$ EUROPA. Rumo à moeda única: síntese histórica da UEM. 22 fev. .2007. Disponível em: $<$ http://europa.eu/scadplus/leg/pt/lvb/125007.htm>. Acesso em: 12 dez. 2008.
} 
Os arranjos cambiais e monetários atuais dos Estados Partes do Mercosul são uma das assimetrias mais relevantes no âmbito de política macroeconômica. Nesse sentido, TRICHES adverte:

\begin{abstract}
Observou-se que, ao longo das últimas décadas, houve uma forte concentração de esforços, pelo menos por parte dos dois principais parceiros do Mercosul, em estabilizar os níveis de preços. A escolha dessa prioridade impôs às economias um contínuo processo de divergência na trajetória das variáveis macroeconômicas fundamentais. Um exemplo disso diz respeito às distorções verificadas nos preços relativos das economias, os quais estão intimamente associados à taxa de câmbio real ${ }^{435}$.
\end{abstract}

Pode-se verificar, também, que, quanto maior o nível de coordenação, torna-se cada vez mais necessário que os países tenham uma política comum no âmbito cambial. A taxa de câmbio é o principal determinante e instrumento para a coordenação econômica, já que é a variável que une diretamente as economias dos países interdependentes. Além disso, também é necessário um nível crescente de credibilidade conforme maior a coordenação, pois diminui as incertezas e os movimentos especulativos.

Diante do que foi exposto, conclui-se que há a possibilidade de um regime de câmbio flexível. É possível que a zona monetária estabelecida possua um regime de câmbio flexível em relação às divisas não comunitárias. Só assim o banco central estaria em condições de conduzir uma política monetária autônoma e controlar o crescimento da massa monetária.

\title{
7.1.3 - Criação de um Banco Central Único: O Banco Central do Mercosul
}

A implementação de uma união monetária no seio do Mercosul subentende a constituição de um Banco Central integrado que viabilize tal união. Por tal razao, o exemplo da União Européia, especialmente no que concerne à criação de seu banco central europeu e do sistema de bancos centrais europeus, torna-se o grande exemplo e referencial para que movimento integracionista semelhante, ou ao menos aproximado, seja desenvolvido no seio do Mercosul.

O esforço combinado de bancos centrais dos Estados Partes do Mercosul visando à estabilização e a abertura de caminho para a constituição de um banco central único é

${ }^{435}$ TRICHES, Divanildo. Op. cit., p. 162. 
"pedra de toque" das ações a serem adotadas visando a integração almejada. Versando sobre a adoção de esforços combinados de bancos centrais nacionais, MACEDO explicita que:

O esforço combinado dos bancos centrais e dos ministérios das finanças nacionais está no centro dos procedimentos multilaterais de supervisão que a União Europeia adoptou para assegurar a convergência das economias nacionais para a estabilidade de preços e para finanças públicas sãs. As origens desses procedimentos reportam-se à cooperação entre bancos centrais durante o padrão-ouro e aos esforços globais para manter alguma estabilidade das taxas de câmbio no princípio da década de 70, depois do colapso do padrão-dólar ${ }^{436}$.

A propósito da imprescindibilidade da criação do Banco Central Único do Mercosul em caso de unificação monetária, VERÇOSA ${ }^{437}$ pondera o seguinte:

Em um contexto de tão grande amplitude, os bancos centrais nacio $\neg$ nais encontram-se despreparados para enfrentar os graves problemas de ocorrência não somente possível, mas certamente vindoura em alguma data ignorada no futuro. Do ponto de vista financeiro internacional, portanto, torna-se necessário um concerto no sentido da criação de mecanismos capazes de prevenirem ou minorarem os efeitos das crises que vierem a se verificar.

A criação de blocos econômicos regionais tem procurado, no campo financeiro, harmonizar os interesses dos Estados participantes e, até mes $\neg$ mo, criar uma única moeda interna. Ainda não há experiência suficiente nessa área para se poder indicar os caminhos mais aceitáveis, dependendo o tema da elaboração de estudos permanentes, buscando as melhores soluções para o problema, de forma a que se estabeleça um desejável equilíbrio das vontades supranacional e individuais de cada membro da comunidade.

(...)

Caso venha a se instituir em futuro ainda indefinido um Banco Central do Mercosul (o Mercosulbanco), ele terá por finalidade regular a moeda desse mercado, que poderá ser para tanto especialmente criada, ou estar referenciada a alguma outra moeda, como o caso do dólar.

Versando sobre o exemplo europeu, tem-se que o Tratado de Maastricht criou uma estrutura designada por Sistema Europeu de Bancos Centrais (SEBC), constituída pelo

\footnotetext{
${ }^{436}$ MACEDO, Jorge. Op. cit., p. 902.

${ }^{437}$ VERÇOSA, Haroldo Malheiros Duclerc. Op. cit., p. 453.
} 
Banco Central Europeu (BCE) e pelos bancos centrais nacionais $(\mathrm{BCN})^{438}$. Os estatutos do SEBC e do BCE constam de um protocolo anexo ao mencionado tratado ${ }^{439}$.

$\mathrm{O}$ BCE é o núcleo do sistema, cabendo-lhe as competências correspondentes à responsabilidade de garantir o cumprimento, pela sua própria atuação ou por meio da ação dos bancos centrais nacionais, das atribuições cometidas ao sistema de integração.

A autorização para a emissão de notas cabe ao BCE, podendo a emissão ser feita por ele próprio ou pelos bancos centrais nacionais. Já a emissão de moeda metálica é feita pelos Estados-Membros, com a aprovação do BCE (art. 105-A).

O BCE é uma instância supranacional. Por si só, é uma experiência única. Sobre sua singularidade, NUNES afirma que:

Caso único na história dos bancos centrais em todo o mundo, o estatuto do BCE não consta de lei ordinária, não é objeto de um instrumento de direito comunitário nem sequer está plasmado no texto de uma Constituição; antes, é parte integrante de um tratado internacional que envolve quinze países (o próprio BCE fala de um "tratado com estatuto constitucional"). A alteração desse estatuto, se vier a revelar-se necessária, pode constituir um problema de difícil solução ${ }^{440}$.

A independência financeira do BCE constitui um sinal claro da sua independência institucional: o orçamento do BCE não integra o orçamento geral da UE nem ele está sujeito à fiscalização do Tribunal de Contas da $\mathrm{CE}$, mas a de um auditor independente. $\mathrm{O}$ estatuto do BCE acompanha de perto o estatuto do Deutsche Bundesbank antes da entrada da Alemanha para a UEM. Com uma diferença relevante: o estatuto do banco central alemão podia ser alterado pelo Parlamento da Alemanha, mas o estatuto não pode ser alterado por ação soberana de nenhum governo ou parlamento nacional, tampouco pelo Parlamento Europeu ${ }^{441}$.

ASSIS entende que o banco central a ser criado em território latino-americano, ao qual denomina "Banco Central da América do Sul”, possuiria um caráter

438 “O SEBC é composto pelo Banco Central Europeu e pelos bancos centrais nacionais dos EstadosMembros, independentemente de terem ou não adoptado o Euro. O seu objectivo principal consiste em manter a estabilidade dos preços. Para o efeito, as missões do SEBC consistem em: definir e executar a política monetária da "zona do euro"; realizar as operações cambiais; deter e gerir as reservas oficiais de divisas dos países da "zona do euro"; promover o bom funcionamento dos sistemas de pagamentos." Banco Central Europeu (BCE). 23 maio 2007. Disponível em: <http://europa.eu/scadplus/leg/pt/lvb/o10001.htm>. Acesso em: 11 dez. 2008.

${ }^{439}$ SILVA, Aníbal Cavaco. Portugal e a moeda única. Lisboa: Verbo, 1998, p. 45.

${ }^{440}$ NUNES, Antônio. Algumas Incidências Constitucionais da Institucionalização da União Econômica e Monetária. Revista da Faculdade de Direito da UFPR, América do Sul, vol. 40, 2004, p. 31.

${ }^{441}$ NUNES, Antônio. Op. cit., p. 32. 
desenvolvimentista $^{442}$. Tal caráter seria derivado de suas relações com os tesouros dos Estados Partes, preparando para a conversão da moeda contábil em moeda plena. Seria estabelecido, progressivamente, um orçamento comum de investimentos em infra-estrutura e indústria básica, financiado por receitas tributárias dos países membros e empréstimos dentro do bloco ${ }^{443}$.

\section{2 - Análise Crítica das Vantagens e Desvantagens da Adoção de uma Moeda Única}

\subsubsection{Vantagens}

Ao abordar as vantagens da adoção de uma moeda única no Mercosul, pode-se destacar:

- maior estabilidade a partir da elaboração conjunta de políticas econômicas;

- ganho de credibilidade e reputação para os Estados Partes e para o Mercosul;

- menor exposição a choques externos;

- maior poder de negociação frente a credores externos e organismos multilaterais;

- ganhos de escala na produção e investimentos;

- possibilidade de inserção de políticas de diminuição das disparidades entre membros.

\subsubsection{Maior Estabilidade a Partir da Elaboração Conjunta de Políticas Econômicas}

Os termos da unificação, com os compromissos que isso implicaria, funcionariam como um propulsor de maior estabilidade.

Em relação ao setor externo, os problemas de balanço de pagamentos de cada país individualmente tenderiam a perder relevância, em caso de unificação monetária. O que seria relevante seria o balanço de pagamentos global do conjunto formado pelos países com moeda única, já que isso determinaria a relação de preço entre essa moeda e o resto do mundo.

Ademais, as vulnerabilidades financeiras, evidenciadas pelo desempenho dos mercados na América Latina nos últimos anos, levam à conclusão de que esses países

$442 \mathrm{O}$ autor entende por "banco central desenvolvimentista" um banco central que opera num padrão muito próximo do Sistema de Reserva Federal (FED) dos Estados Unidos.

${ }^{443}$ ASSIS, José. Moeda, soberania e trabalho - uma proposta crítica para o desenvolvimento integrado da América do Sul. Comunicação \& Política, vol. 24, nº 1, jan./abr. 2006, p. 179. 
estariam, provavelmente, bem menos expostos às turbulências financeiras se optassem por algum esquema de coordenação macroeconômica, em especial no âmbito da escolha de um regime de câmbio.

Por outro lado, a experiência da União Européia deixa transparecer um ganho significativo de segurança financeira a partir da coordenação macroeconômica, particularmente no que se refere a termos de uniformização de regras para as atividades financeiras e segurança para as autoridades monetárias nacionais pelo fato de haver um credor de última instância, supranacional, capaz de equilibrar as necessidades de liquidez nos diversos mercados ${ }^{444}$.

Abordando em especial a relação Brasil - Argentina, tem-se que o grande benefício que a unificação monetária acarretaria para a Argentina seria o fím da incerteza quanto à política cambial brasileira, diminuindo a importância da chamada "Brasildependência". Isso porque, embora uma parcela da ordem de $30 \%$ ou mais das exportações continuasse sendo exportada para o país vizinho, ela não mais correria o risco de sofrer problemas internos decorrentes de uma desvalorização unilateral deste, já que, a partir da unificação, a paridade bilateral, por definição, ficaria congelada ao desaparecerem as respectivas moedas nacionais ${ }^{445}$.

Adicionalmente, outros benefícios decorreriam da centralização das políticas monetária e cambial e também seriam vantajosos na medida em que garantem maior estabilidade aos estados partícipes. SILVA, analisando o processo de implantação do euro na Europa, aponta que:

Esta centralização das políticas monetária e cambial, justaposta ao mercado interno (...) constitui uma pressão poderosa no sentido do reforço da coordenação das políticas não monetárias dos EstadosMembros, da convergência dos respectivos sistemas fiscais e do aprofundamento da união política européia ${ }^{446}$.

Nesse aspecto RIBEIRO ${ }^{447}$ também destaca que "os principais benefícios da união monetária podem ser destacados com o aumento da credibilidade da política monetária e redução da inflação interna, eliminando a incerteza cambial; com isso, diminuirão as

\footnotetext{
${ }^{444}$ LINS, Maria Antonieta. Op. cit., p. 7.

445 GIAMBIAGI, Fábio. Mercosul: Por Que a Unificação Monetária faz Sentido a Longo Prazo? Ensaios BNDES, nº 12, Rio de Janeiro, dez. 1999, p. 26.

${ }^{446}$ SILVA, Aníbal Cavaco. Op. cit., p. 22.

${ }^{447}$ RIBEIRO, Maria de Fátima. Op. cit., p. 11.
} 
resistências das indústrias domésticas a integração nacional e a redução dos custos de transação e de conversão de moedas”.

Tais conclusões, sem dúvida, servem de lição prática aos Estados Partes do Mercosul, pois esses já vêm constituindo um mercado comum, passo preliminar para adoção de uma moeda única. A experiência européia demonstrou que a centralização monetária e cambial produz a integração dos mercados, a globalização dos mercados financeiros e o reforço da interdependência econômica entre os países membros, conduzindo à estabilidade macroeconômica e resultando em um forte aumento da coordenação de políticas econômicas visando criar uma zona de estabilidade efetiva no bloco. Dessa forma, se elimina a incerteza cambial, promove-se a eficiência econômica e o desenvolvimento do comércio intracomunitário e se estimula o investimento e o crescimento econômico.

\subsubsection{Ganho de Credibilidade e Reputação para os Estados Partes e para o Mercosul}

Tendo em vista que a adoção de uma moeda única passa pela redução dos coeficientes de endividamento público na região, pela definição de parâmetros realistas dentre a gama de medidas necessária para a adoção e manutenção da união monetária, temse que os Estados Partes ganharão credibilidade, melhora da sua reputação, em face dos acertos políticos e resultados positivos das medidas implementadas no seio do bloco. Portanto, dentre outras coisas, a superação do crônico problema das inflações de Argentina e Brasil levariam a um ganho de respeitabilidade e assimilação do entendimento de maior maturidade dos referidos Estados através do movimento de integração ${ }^{448}$.

\subsubsection{Menor Exposição a Choques Externos}

A adoção de uma moeda única levaria a uma redução da incerteza cambial. Com isso, ter-se-ia a possibilidade de cálculos econômicos mais precisos para projetos envolvendo intercâmbio de produtos dentro da região monetária e diminuiria a variância da expectativa de flutuação da moeda em relação ao mundo como um todo, já que a

\footnotetext{
${ }^{448}$ GIAMBIAGI, Fábio. Uma proposta de unificação monetária dos países do Mercosul. Ensaios BNDES, ${ }^{\circ}$ 4, Rio de Janeiro, p. 10.
} 
variabilidade de uma moeda comum em relação ao resto do mundo tende a ser menor do que a da moeda de um país específico ${ }^{449}$.

O compromisso com certos requisitos mínimos de estabilidade macroeconômica contribuiria, per se, para diminuir o "risco-país"; à medida que o conjunto dos Estados Partes assumisse o mesmo tipo de compromissos, ele tenderia a se diferenciar do caráter ainda negativo da "marca" América Latina na memória dos investidores, diminuindo o "risco-região" do Mercosul ${ }^{450}$.

No caso do Brasil, aspecto relevante para a adoção da moeda única está justamente na superação das vulnerabilidades do real, resolvendo problemas antigos com o fortalecimento de uma moeda única regional ${ }^{451}$.

Sobre a redução da inflação interna, e conseqüente eliminação da incerteza cambial, importante ressaltar que há ganho em eficiência monetária se adotada uma taxa de câmbio fixa entre os países que integrarão a área monetária ${ }^{452}$. Esse ganho está associado à redução de incertezas, à eliminação de expectativas (em relação à variabilidade e ao risco cambial) e à redução dos custos de transação ${ }^{453}$.

Resumindo, conforme SILVA, a adoção de uma união monetária, com uma moeda única, é "uma solução que elimina o problema de credibilidade associado à possibilidade de realinhamento nas taxas de câmbio das moedas nacionais, elimina os custos de conversão de umas moedas nas outras e atenua as tensões entre os Estados membros quanto à política monetária apropriada" ${ }^{, 454}$.

\subsubsection{Maior Poder de Negociação frente a Credores Externos e Organismos Multilaterais}

A formação de um bloco econômico mais coeso proporcionado por uma moeda única permitiria ao Mercosul aumentar e fortalecer sua posição nas negociações em plano internacional, especialmente no que concerne às negociações do Fundo Monetário Internacional - FMI, do Banco Mundial, da Organização Mundial do Comércio e das Nações Unidas. A conseqüência prática seria que os Estados Partes teriam uma

\footnotetext{
${ }^{449}$ GIAMBIAGI. Op. cit.p. 15.

${ }^{450}$ GIAMBIAGI. Op. cit., p. 25.

${ }^{451}$ JANSEN, Letácio. A retórica do Mercosul e a moeda única regional. Revista Forense, vol. 354, p. 384.

${ }^{452}$ TRICHES, Divanildo. Op. cit., p. 47.

${ }^{453}$ Idem.

${ }^{454}$ SILVA, Aníbal Cavaco. Op. cit., p. 160.
} 
possibilidade maior de verem seus pleitos atendidos comparativamente ao que seria observado caso negociassem fora do bloco, em face da maior unidade que o bloco em si representaria. A possibilidade de expressão de "uma única voz" no Mercosul seria fortalecida e melhor creditada tendo em vista o incremento da integração dos Estados Partes, manifestando ganho de maturidade em relação, por exemplo, ao momento de criação do Mercosul, no início da década de 1990.

O fortalecimento da influência internacional do bloco, com papel mais relevante nos desdobramentos internacionais é exemplificado, no âmbito de integração européia, pela conclusão do Relatório Delors ${ }^{455}$, que considerou que "a realização de uma União Econômica e Monetária conferirá à Comunidade um papel mais importante nas negociações internacionais e aumentará a sua capacidade de influenciar as relações econômicas entre os países industrializados e países em desenvolvimento”. Ora, quanto maior o peso relativo de determinado bloco na produção e comércio mundiais, maior sua influência na cooperação monetária e financeira internacional. A moeda única é um contributo decisivo para que, na cena internacional, um bloco regional passe de espaço econômico a potência geopolítica ${ }^{456}$.

\subsubsection{Ganhos de Escala de Produção e Investimentos}

A instabilidade econômica tem sido uma das principais causas inibidoras do investimento na região. Nesse sentido, um acordo de unificação monetária entre os países do Mercosul seria um poderoso reforço para a estabilidade de cada um dos EstadosMembros do acordo e funcionaria como um fator de estímulo para o investimento nessa região, tanto estrangeiro como privado em geral.

A estabilidade de preços e o compromisso com metas fiscais apropriadas diminuiriam a resistência dos empresários dos Estados Partes e dos demais investidores estrangeiros em assumir compromissos de longo prazo, imobilizando capital em projetos de investimento.

O Mercosul transformar-se-á em uma plataforma de exportação para terceiros países, tendo em vista que o aumento da integração entre os Estados Partes, somando as

\footnotetext{
${ }^{455}$ Em junho de 1988, o Conselho Europeu confirmou o objetivo da realização progressiva da União Económica e Monetária (UEM). Atribuiu a um comitê presidido por Jacques Delors, que, na altura, era o presidente da Comissão Européia, o mandato de estudar e propor um plano concreto para levar a efeito a união.

${ }^{456}$ SILVA, Aníbal Cavaco. Op. cit., p. 169.
} 
quatro economias da região, representaria um ativo extremamente importante como fator decisivo na escolha da localização de novos empreendimentos de grandes grupos empresariais a fim de abastecer a demanda mundial ${ }^{457}$.

Exemplo de aumento da produção na adoção de moeda única pode ser depreendido do processo de implantação do euro, onde, por meio da publicação de todos os preços de bens e serviços em todo o território coberto pela moeda, houve o aumento da transparência e da concorrência no mercado europeu.

Além do aumento da concorrência, fator direto para o aumento da produção, a exigência de uma conduta econômica rígida, por parte dos Estados e em relação aos participantes, levou à impulsão do comércio interno, já que se assegurou, com isso, uma melhor alocação de recursos e o favorecimento dos investimentos e da poupança, promovendo o crescimento e o emprego.

\subsubsection{Possibilidade de Inserção de Políticas de Diminuição das Disparidades entre}

\section{Membros}

HAWKINS e MASSON ${ }^{458}$ entendem que a moeda única, se adotada por um conjunto de Estados, possibilitaria uma maior cooperação política e, ao mesmo tempo, também, poderia tornar mais fácil a implantação de reformas estruturais.

A moeda única pode vir a ser um instrumento central de integração e de desenvolvimento no Mercosul. A moeda única funcionaria, inicialmente, como moeda contábil, estimulando o comércio e o financiamento do desenvolvimento da infra-estrutura comum. O arranjo monetário deveria ser de tal ordem que os investimentos de infraestrutura na região poderiam ser financiados por emissão da moeda comum, na proporção dos gastos em moeda local.

Ademais, a unificação monetária refletiria na diminuição das disparidades no nível de desenvolvimento socioeconômico dos países integrantes, bem como, segundo GONZALEZ CRAVINO ${ }^{459}$, seria uma resposta aos problemas gerados pela globalização na medida em que se expressar em maior coesão social.

\footnotetext{
${ }^{457}$ GIAMBIAGI. Op. cit., p. 24-25.

${ }^{458}$ HAWKINS, J.; MASSON, P. Op. cit.

${ }^{459}$ GONZÁLEZ CRAVINO, S. Globalización, integración y cohesión social: el caso Mercosur. Revista de Derecho del Mercosur, $\mathrm{n}^{\circ}$ 1, fev., 2000, p. 79-80.
} 


\subsubsection{Desvantagens}

\subsubsection{Perda de Parte da Soberania e Conseqüente Autonomia sobre Certas Políticas Governamentais}

A perda de soberania é uma das desvantagens mais evidentes ao falar-se em união monetária. A adoção de uma moeda única representa uma renúncia ao uso de instrumentos clássicos de política econômica, em particular a política cambial, o que coloca em um plano subalterno a nacionalidade da moeda.

Como informa FONSECA, "a moeda sempre foi expressão do poder de um soberano sobre determinado e limitado espaço territorial. Através dela o soberano vinculava os povos a seu poder, simbolizando assim o domínio político e econômico sobre eles exercido" $" 460$.

Tal situação modifica-se na medida em que a combinação de moeda única com o respeito aos critérios macroeconômicos de convergência diminui a capacidade de ação dos governos, afetando, desse modo, a soberania nacional. Com a implementação de uma moeda única haverá perda, por parte dos governos envolvidos na união monetária, da possibilidade de usar a política cambial como instrumento de ajuste. Além disso, haverá a necessidade de respeitar certos parâmetros macroeconômicos que limitarão a possibilidade de incorrer em políticas expansionistas, geradoras de déficits e/ou inflação ${ }^{461}$.

Com a adoção do euro, por exemplo, requer-se das nações que compõem a União Européia e que aderem à implantação da nova moeda a renúncia ao poder de emitir moeda e de decidir unilateralmente sobre suas relações exteriores e sua segurança. Dentre as exigências presentes em regulamentação específica do Tratado de Maastricht, está, também, a de que os países adotantes do euro têm de reduzir seu déficit público a menos de $3 \%$ do Produto Interno Bruto.

Por intermédio do Pacto de Estabilidade e Crescimento, não integrante do Tratado de Maastricht e que tem por objetivo dar ao euro status de moeda forte, esses mesmos países se comprometem com a estabilidade econômica, através do respeito pelos limites de flutuação do Sistema Monetário Europeu durante, pelo menos, dois anos (mais ou menos 2,25\%); da manutenção da taxa de inflação em valor não superior a 1,5\% à média das taxas dos três Estados-Membros com melhores resultados nessa matéria; manutenção do

\footnotetext{
${ }^{460}$ FONSECA, João Bosco L. Direito econômico. 2. ed. Rio de Janeiro: Forense, 1997, p. 127.

${ }^{461}$ GIAMBIAGI. Op. cit., p. 09.
} 
endividamento público em nível inferior a $60 \%$ do PIB; e da manutenção da taxa de juro a longo prazo em valor que não supere em mais de $2 \%$ a taxa dos países com a mais baixa inflação. Percebe-se, pois, nitidamente, a perda de poder do Estado-Nação a fim de ambientar-se às regras do bloco do qual faz parte.

No caso do Mercosul, ocorre similar perda:

Para a implementação do Mercado Comum na América Latina é imprescindível a concretização do Direito Comunitário ou Direito da Integração. Só por meio dele os Estados conseguirão transformar mercados nacionais num único e compartilhado mercado. Graças à característica de supranacionalidade, o Direito da Integração implica primazia sobre os direitos internos - nacionais e na uniformidade de interpretação e aplicação das normas gerais que regerão o bloco econômico. (...) para a viabilidade do mercado comum impõe-se a flexibilização da noção tradicional de soberania ${ }^{462}$.

No Brasil, em especial, o receio maior em relação ao Mercosul é o de perda de capacidade de reação diante de uma situação externa adversa, o que é claramente valorizado pelo país após a bem-sucedida desvalorização de $1999^{463}$.

\subsubsection{2 - Altos Custos para a Transição Monetária}

Os críticos da integração a partir da adoção de uma moeda única apontam que podem existir altos custos de transição da moeda nacional para a comum, o que ocorre porque, com a coexistência de moedas, poderá deflacionar a mais valiosa. Pode ocorrer a flutuação da taxa de câmbio, o que induziria à supervalorização de algumas moedas e ao rebaixamento de outras. Tal foi o motivo para a Inglaterra e os países escandinavos, que possuíam as economias mais fortes e mais estáveis dentre as integrantes da União Européia, não desejarem ingressar na união monetária européia, sem, no entanto, aderirem ao euro, até o presente.

É preciso, ainda, atentar-se a outro detalhe: no período de transição haverá a necessidade de manter dupla contabilidade e de existirem dois sistemas financeiros. Em uma de suas críticas à unificação monetária no Mercosul, GIAMBIAGI, justamente, afirma

\footnotetext{
462 RANZANI, Katia Maria. As barreiras constitucionais do Brasil para a harmonização da legislação tributária no Mercosul. Revista Jurídica da Universidade de Franca, Franca, vol. 3, nº 4, maio 2000 , p. 80.

${ }^{463}$ GIAMBIAGI, Fábio. A Moeda Comum como Base do Crescimento do Brasil e da Argentina. Ensaios BNDES, nº 13, Rio de Janeiro, nov. 2001, p. 10.
} 
que além dos países não preencherem, por ora, os requisitos de uma área monetária ótima (AMOs), a renúncia às políticas monetária e cambial domésticas teria custos elevados ${ }^{464}$.

Entre as causas para tais custos também está a de que a moeda única teria de substituir a nacional no planejamento a médio e longo prazo, no faturamento, nos pagamentos e gestão de tesouraria, na afixação de preços, nos catálogos, nas folhas salariais, na contabilidade, nos contratos, nas obrigações fiscais. Milhares de programas informáticos teriam de ser alterados e as máquinas registradoras e de venda automática ajustadas. A vida do cidadão seria profundamente afetada, pois os salários, as pensões, os depósitos, os empréstimos e os impostos passam a ser denominados na moeda única, em substituição à nacional. As pessoas perderiam a referência dos preços, exigindo-se delas que se habituassem a receber, pagar e a raciocinar a partir da nova medida de valor. Até mesmo as administrações públicas teriam de se adaptar com certa dificuldade, visto que passariam a fazer na nova moeda os pagamentos de despesas e prestações sociais, a cobrança de impostos, contribuições, taxas e a emissão de dívidas públicas. Entretanto, neste particular, a experiência européia com o euro, veio a demonstrar que esse problema foi resolvido sem maiores inconveniências.

\subsubsection{Sacrifícios Sociais Consideráveis}

Levando em consideração a necessária adequação cambial que ocorreria nos Estados Partes da integração monetária, poderia decorrer prejuízo à competitividade das exportações e limitação da capacidade de crescimento, pelo impacto da taxa de câmbio sobre a demanda de importações.

Além disso, há que se destacar que os custos relacionados com os ajustes fiscais poderiam acarretar aumento da carga tributária, pela incidência de cortes orçamentários caso o ajuste se desse sobre a despesa.

\subsubsection{Precária Flexibilização da Legislação Trabalhista Resultando em Aumento da Inflação e Diminuição dos Empregos}

A promoção dos ajustes requeridos pela necessidade de aumentar a competitividade e os preços relativos de um Estado será transferida para o mercado de trabalho, o que exigiria a imediata adaptação e flexibilização da legislação trabalhista

${ }^{464}$ GIAMBIAGI, Fabio; RIGOLON, Francisco José Zagari. A Economia Brasileira: Panorama Geral. BNDES, Estudos BNDES, nº. 8, 1999, p. 12. 
nacional, sob pena o ajuste ocorrer através do aumento da inflação, que reduziria, de todo modo, o valor do salário real, em virtude do aumento dos preços (perda do poder de compra) ou da perda de produção, que causaria o mesmo efeito nefasto, deflacionando os salários nominais. 


\section{CONCLUSÕES}

Diante de tudo que foi exposto, cumpre ratificar a nossa posição, já anunciada na parte introdutória do presente trabalho, no sentido da impossibilidade da adoção de uma moeda única no âmbito do Mercosul.

Com efeito, impende frisar que não discordamos que a implantação de uma moeda única por parte de blocos econômicos em formação, como é o caso do Mercosul, seja uma tendência mundial, a partir, sobretudo, do aparente sucesso alcançado pelo euro na União Européia.

Fazemos questão de enfatizar a expressão "aparente sucesso", pois, a nosso ver, ainda é muito prematuro para se falar em união monetária bem-sucedida, haja vista que, consoante observamos cotidianamente, o euro, que pretendia fazer frente ao dólar dos Estados Unidos - moeda ainda dominante no mundo até hoje -, foi incapaz de resistir à primeira crise mundial ocorrida desde sua existência. Pelo que se tem notado, essa crise certamente continuará afetando, e de maneira bem drástica, a área do euro por mais alguns pares de anos.

Ora, com toda a pujança com que surgiu o euro, especialmente pelo fato de ser adotado por países de uma região considerada a segunda maior potência em termos econômicos, superada até então apenas pelos Estados Unidos da América, era de se esperar que a sua moeda única resistisse, com todo o vigor, diante de um dólar representativo de uma economia em declínio, em razão da crise dos chamados créditos "subprime", gerada, essencialmente, pela falta de prudência de várias instituições norte-americanas e pela ausência de controles adequados por parte das autoridades supervisoras, que se deixaram seduzir pela capciosa idéia de que o mercado poderia se manter forte e sustentável por vias da auto-regulação.

Nesse diapasão, o que, de fato, refutamos em relação àqueles que, com todo o respeito, posicionam-se no sentido da possibilidade de adoção de uma moeda única no âmbito do Mercosul, são os argumentos baseados essencialmente no plano institucional desenvolvido a partir do paradigmático modelo europeu.

Em primeiro lugar, como afirmamos alhures, pensamos ser prematuro concluir pelo sucesso do euro como moeda única, porquanto se trata de uma experiência que ainda 
não se consolidou e que está enfrentando amplas dificuldades para superar a crise econômica atual, que, embora originada nos Estados Unidos da América, vem causando imensos prejuízos à economia da área do euro, como é público e notório. Esse fato fez transparecer, inclusive, a imensa volatilidade que aquela moeda única vem sofrendo, em que pesem todas as medidas financeiras e de ajuste fiscal que têm sido adotadas pelas autoridades monetárias, a fim de tentar manter sua estabilidade. Constata-se que, em questão de poucas semanas, a cotação do euro chegou a variar cerca de 30\%, o que, certamente, afetou um grande número de agentes econômicos que perderam totalmente a noção de preços de referência nos seus negócios internacionais, o que afeta negativamente a construção européia.

Em segundo lugar, a implantação do euro seguiu um sistema autocrático, ou seja, de cima para baixo, sem consulta às populações diretamente atingidas pela sua imposição, que, aliás, se sentiu surpreendida, e, por isso, manifestaram sua desaprovação em relação ao novo padrão monetário introduzido na União Européia. Em razão disso, inclusive, no início da implantação da nova moeda, noticiou-se, na Alemanha, que as pessoas ainda guardavam, em seus cofres, uma razoável quantidade de notas e moedas nacionais, na expectativa de que o euro viesse a sucumbir e aquele dinheiro valioso de outrora voltasse a circular com poder de compra superior ao da moeda comum utilizada somente por parte dos países da União Européia. Não sabemos, no plano empírico, se tal realidade ainda se confirma. Isso demonstra, inequivocamente, que toda a engenharia para a implantação do euro foi feita "intra-muros", promovida pelos governantes de plantão dos vários paísesmembros, desprovida do efetivo envolvimento e anuência da população, dado que a desconfiança inicial foi sintomática.

Em terceiro lugar, ainda que, no futuro, quiçá distante, o euro venha efetivamente a se confirmar, de fato, um sucesso em termos de padrão monetário para o mundo, no nosso entendimento, é impossível que outro bloco econômico possa copiar com eficácia esse modelo, que se revela irrepetível por todas suas circunstâncias. Apenas à guisa de exemplo, basta observar que a área do euro foi composta originariamente, em sua arrancada política e econômica, apenas por países desenvolvidos, enquanto no Mercosul os Estados Partes são considerados países "em desenvolvimento" - expressão mais branda para evitar termos negativos e vexatórios como "subdesenvolvido" ou "menos desenvolvido" -, o que, por si só, já demonstra a incompatibilidade entre o Mercosul e a União Européia e, por conseguinte, a impossibilidade de adoção da mesma sistemática de 
implantação do euro como moeda única na União Européia. Porém, fatores geopolíticos, históricos e econômicos mais profundos dão conta das diferenças estruturais entre essas sociedades e seus respectivos modelos institucionais.

Em quarto, as razões que levaram ao projeto de integração da Europa são completamente distintas das que culminaram com a constituição do Mercosul. Lá o intuito primordial foi o de criar um projeto que evitasse novos conflitos bélicos entre as nações da Europa, pois o continente tinha acabado de emergir de duas devastadoras Guerras Mundiais, após uma série de outros conflitos de menores proporções. Ao mesmo tempo, a implementação do euro como moeda única estava intimamente relacionada à coesão entre os países constitutivos da União Européia, o que, indubitavelmente, não é o caso do Mercosul.

Em quinto lugar, diferentemente do que o ocorre na União Européia, há fragilidade na manutenção do cumprimento da cláusula democrática estabelecida no Protocolo de Ushuaia, por parte não apenas dos atuais membros do Mercosul, especialmente o Paraguai, como também dos que vierem a integrá-lo futuramente (notadamente a Venezuela, que procura ingressar no bloco até março próximo), em razão das disputas e conflitos políticos que se travam constantemente entre os governantes dos países do Mercosul. Isso já constitui, por si só, uma dificuldade no aprofundamento da integração regional, o que, a nosso ver, trata-se de insuperável obstáculo na tentativa de adoção de uma moeda única para o bloco.

Em sexto lugar, a adoção de moeda única causaria inevitável perda de soberania dos países do bloco, questão inaceitável para os seus governantes atuais, que, além do arraigado conceito de soberania, lamentavelmente, só tratam das questões envolvendo o Mercosul visando a promoção política individualizada, em detrimento do interesse comum dos membros do bloco.

Impende lembrar que ainda falta maturidade política e consistência jurídica ao Mercosul para se cogitar da união monetária. Observando o modelo europeu, verifica-se que aquele continente levou quase cinqüenta anos para chegar à união monetária e econômica atual, além de ter, ao longo desse período, harmonizado suas legislações internas a fim de viabilizar a imediata internalização do Direito Derivado relativo à União Européia. Já o Mercosul, com cerca de dezoito anos de existência, sequer alcançou o objetivo inicial do bloco, concernente à integração regional adequada aos anseios políticos e econômicos dos seus Estados-Membros, tampouco conseguiu criar qualquer entidade 
com poderes supranacionais, o que, a nosso sentir, inviabiliza por completo qualquer pretensão de implantação de moeda única no bloco.

Ademais, consoante apontado no decorrer dessa pesquisa, nem o Tratado de Assunção, nem as normas constitucionais dos Estados-Membros do Mercosul estabelecem qualquer menção relativamente à possibilidade de implementação de uma união monetária no âmbito do Mercosul. Note-se, ainda, que nos casos das Cartas Constitucionais brasileira e uruguaia sequer houve a flexibilização das normas para internalização dos tratados internacionais relativos ao Mercosul, que acabam passando por processo idêntico a qualquer norma de Direito Derivado.

Como se isso não bastasse, não se pode cogitar da implantação de uma moeda única para diferentes países sem que haja, inexoravelmente, a adoção de regime cambial e política monetária única. O problema, quanto aos países que compõem o Mercosul, é que há, atualmente, dois países com câmbio flutuante - Brasil e Uruguai -, dois com câmbio administrado - Argentina e Paraguai. Em relação à política monetária, o Brasil é o único país do bloco a adotar o Regime de Metas de Inflação (Inflation Target). No mercado comum europeu a meta inflacionária dos países do bloco é de $2 \%$ ao ano. A convergência para a moeda única demandaria, ainda, a identidade de outros fatores, como políticas de abertura comercial (barreiras tarifárias). Não menos importante é a existência de instituições oficiais que regulem o mercado financeiro, a exemplo de Bancos Centrais independentes, institutos de estatística, como o IGBE. Outro fator relevante é a existência de marcos regulatórios compatíveis entre os países, que devem funcionar em harmonia regulatória. Na situação atual, parece impossível a convergência dos países componentes do Mercosul para a mesma meta de inflação através da mesma taxa de juros, quando, por exemplo, os atuais níveis do primeiro Brasil são de 6 a 7\% ao ano, enquanto a Argentina convive com mais de $20 \%$ ao ano. Além disso, a normativa e o marco regulatório para o mercado financeiro dos países do Mercosul, à exceção do Brasil, não possibilita que os mercados funcionem dentro das mesmas regras e no mesmo nível de segurança.

No tocante aos supostos óbices ao comércio internacional causados pela relutância na adoção de uma moeda única no âmbito do Mercosul, o nosso ponto de vista, contrariando certamente aqueles que defendem a união monetária, é no sentido de que esse fator não seja tão importante e significativo.

Pela nossa experiência pessoal, na atuação por quase 40 anos nos mercado de câmbio, em que acompanhamos a evolução dos negócios comerciais e financeiros 
envolvendo a troca de moedas, a questão do risco cambial, que, segundo alguns, inibiria o incremento de negócios no comércio internacional, está longe de ter um grande impacto negativo, considerando-se que existem mecanismos de proteção ("hedge") que, bem administrados, neutralizam esse suposto inconveniente, e, por outro lado, podem trazer até vantagens adicionais aos agentes econômicos.

Da mesma forma e pelas mesmas razões, entendemos que a redução dos custos de transação decorrentes da adoção de uma moeda única, acaba sendo desprezível em comparação com a atual quantidade de moedas, relativa ao número de países que compõem o bloco.

Por outro lado, é evidente que, conquanto de forma defasada, o saldo da Balança Comercial Brasil/Mercosul é fortemente afetado pelas mudanças nas taxas de câmbio, porém é influenciado ainda por mudanças em outras variáveis como o nível de renda interna e externa e os termos de troca, sendo certo, também, que os desequilíbrios comerciais gerados pelas políticas cambiais retardam o aprofundamento do processo de integração, na medida em que as políticas econômicas adotadas para corrigi-los inviabilizam a cooperação regional, pois geram reações protecionistas devido à falta de coordenação das políticas macroeconômicas dos países do bloco.

Assim, a manutenção do incremento dos volumes no comércio internacional está muito mais relacionada com a estabilidade da moeda nacional, que deve evitar oscilações bruscas, inesperadas e imprevistas da taxa de câmbio, que inibe o fluxo de negócios. Exemplo disso é que, recentemente, os exportadores de calçados do Rio Grande do Sul tiveram uma queda nas suas operações, mesmo com o aumento da taxa de câmbio de R\$ 1,70 para R\$ 2,55, por dólar dos Estados Unidos, ou seja, mais de 50\% de variação em menos de um mês. A razão dessa queda deve-se à pressão dos compradores no exterior pela redução proporcional à variação cambial nos preços em dólar. Contudo, os exportadores calçadistas brasileiros deixaram de fazer as vendas com o desconto pleiteado pelo receio fundado - dada a volatilidade da taxa de câmbio - de terem prejuízo irrecuperável no momento da realização da operação de câmbio. Assim, as vendas no comércio internacional restaram temporariamente suspensas, o que acarreta a possibilidade de que os compradores busquem outros fornecedores, de modo que os exportadores correm sério risco de perderem o seu mercado.

Por conseguinte, a introdução da moeda única no âmbito do Mercosul é questão recorrente e atual, não só porque está na pauta de discussões recentes de vários governos 
dos países do bloco, especialmente no Brasil e na Argentina, mas, também, pelo fato de que se imaginarmos que, num determinado momento no futuro, tivermos uma única moeda adotada por todos as nações da comunidade mundial, assistiremos, então, ao fim inexorável e definitivo de todos os mercados de câmbio atualmente existentes. Não haverá mais moedas para trocar. Entretanto, entendemos que tal possibilidade, isto é, a adoção uma moeda única, também em termos universais, está muito distante de um dia ser alcançada. Se fosse, de fato, a solução ideal, a comunidade internacional já teria adotado essa medida.

A comprovar esta afirmação, basta observar que o dólar dos Estados Unidos (fazemos esta distinção tendo em vista que há mais de uma dezena de outros países que adotam a denominação dólar para suas moedas nacionais, como por exemplo, o Canadá, a Austrália etc.), apesar de considerada, até o momento, como uma moeda universal, já que é aceita, na prática, por quase todos os países e indivíduos, anda que proibido o seu curso legal pelos governos, jamais logrou em se tornar candidata a desempenhar o papel de uma moeda única. O máximo que se adotou foi o fenômeno da "dolarização", ou seja, o atrelamento de moedas nacionais ao dólar dos Estados Unidos.

Todas as questões que acabamos de suscitar são e naturalmente devem ser tomadas em linha de consideração pelos poderes políticos e pelos legisladores, porque o Direito tem uma linguagem metajurídica que lhe é subjacente e determinante, um verdadeiro significante jurídico. Como é cediço, o sistema normativo orienta-se não às cegas, mas por fatores políticos, institucionais, econômicos, históricos, que não raro são desprezados pelos juristas em suas investigações científicas. Aqui, ao contrário, investigamos os fatores subjacentes ao sistema normativo brasileiro, para mostrar não apenas as razões do Direito, mas também aquelas pelas quais o legislador optou pela impossibilidade de uma moeda única no âmbito do Mercosul, ao deixar, consciente ou inconscientemente, de estabelecer esta previsão.

Nesse contexto, no que tange aos aspectos jurídicos, ressaltamos que sem a harmonização ${ }^{465}$ das legislações internas dos respectivos países partes, torna-se impossível cogitar-se da adoção de uma moeda única, não só no âmbito do Mercosul, mas em qualquer outro bloco econômico. A propósito, são as palavras do ilustre mestre LUIZ

\footnotetext{
465 "Harmonização das leis significa adotar normas comuns: cada um dos Estados adotaria as mesmas normas para aplicar aos mesmos fenômenos". MAGALHÃES. José Carlos de. Guichê único europeu como referencial. In DEBATES: A defesa da concorrência no Mercosul. Seminário realizado em 2 de agosto de 1996, na sede da FIESP. São Paulo: Master's Gráfica e Editora Ltda., 1997, p. 47.
} 
CARLOS DE AZEVEDO: "E de todo este revolver dos novos quadros jurídicos, o direito comum e universal ganhará tempo e lugar nos países que o adotam, constituindo a origem e marca do direito continental, cujo regime acompanhamos"466. 


\section{BIBLIOGRAFIA}

AGUILLAR, Fernando Herren. Direito econômico: do Direito Nacional ao Direito Supranacional. São Paulo: Atlas, 2006.

ALESINA, A.; BARRO, R.J. Dollarization. American Economic Review, vol. 91, nº 2 , maio 2001.

ALMEIDA, Paulo Roberto. O Mercosul no contexto global. BASTOS, Celso Ribeiro; FINKELSTEIN, Cláudio (orgs.). Mercosul: lições do período de transitoriedade. São Paulo: Instituto Brasileiro de Direito Constitucional, 1998.

AMBOS, Kai; PEREIRA, Ana Cristina. Mercosul e união européia: perspectivas da integração regional. Rio de Janeiro: Lúmen Juris, 2004.

ANDRADA, Antonio Carlos Ribeiro de. Bancos de emissão no Brasil. Rio de Janeiro: Livraria Leite Ribeiro, 1923.

ANDREZO, Andréa Fernandes; LIMA, Iran Siqueira. Mercado financeiro: aspectos históricos e conceituais. São Paulo: Thomson Learning, 2006.

ARAÚJO, Luis; MARTINEZ, Mônica. Análise Comparada da Integração no Mercosul e na União Européia. Revista dos Alunos do Programa de Pós-Graduação em Integração Latino-Americana, Florianópolis, UFSM, vol. 2, nº 1, 2005.

ASCARELLI, Tullio. Obbligazioni pecuniarie. Roma e Bolonha: Nicola Zanichelli, 1959.

ASSIS, José. Moeda, soberania e trabalho - uma proposta crítica para o desenvolvimento integrado da América do Sul. Comunicação \& Política, vol. 24, nº 1, jan./abr. 2006.

AZEVEDO, Luiz Carlos de. Introdução à História do Direito. São Paulo: Revista dos Tribunais, 2005.

AZEVEDO, Thales de.; LINS, Edilberto Quintela Vieira. História do banco da Bahia 1858-1958. Rio de Janeiro: José Olympio, 1969. 
BACHA, Carlos José. Macroeconomia aplicada à análise da economia. São Paulo: EDUSP, 2004.

BAPTISTA, Luiz Olavo. O Mercosul, suas instituições e ordenamento jurídico. São Paulo: LTr, 1998.

BARRAL, Welber. Defesa Comercial no Mercosul. In: BASSO, Maristela (org.). Mercosul - Mercosur: Estudos em homenagem a Fernando Henrique Cardoso. São Paulo: Atlas, 2007.

BARROS, José Fernando. Negociações para a criação de uma moeda única na união européia. In: MEDEIROS, Antonio (Org). O Ensino Jurídico no Limiar do Novo Século. Porto Alegre: EDIPUCRS, 1997.

BATISTA JUNIOR, Paulo Nogueira. Dolarização: significado e conseqüências. Econômica, nº 3, jun. 2000.

BAUDHUIN, Fernando. Princípios de economia contemporânea. São Paulo: Difusão Européia do Livro, 1966.

BAYOUMI, T.; EICHENGREEN, B. One money or many? Analysing the prospects for monetary unification in various parts of the world. Princeton Studies in International Finance, no 76, Sept. 1994.

BERGER, Pierre. La monnaie et ses mécanismes. Presses Universitaires de France. 6. ed., Presses Univesitaires de France, 1975.

BETTATI, Mario. Le droit des organizations internationales. Paris: PUF, 1987.

BITTENCOURT, Silvia. O Euro. São Paulo: Publifolha, 2002.

BLAUG, Mark. Classical Economics. The New Palgrave: A Dictionary of Economics, vol. $1,1987$.

BRAILLARD, Philippe. Teoria das Relações Internacionais. Lisboa: Fundação Calouste Gulbenkian, 1990. 
BRASIL. Leis etc. Colecção das leis do Brazil de 1808. Rio de Janeiro: Imprensa Nacional, 1891.

BRESSER-PEREIRA, Luiz Carlos. As Incertezas do Plano Collor. Revista Brasileira de Economia, no 45 (especial), jan. 1991.

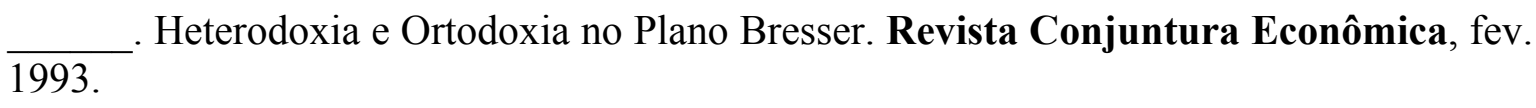

. Os Dois Congelamentos de Preços no Brasil. Revista de economia política, vol.

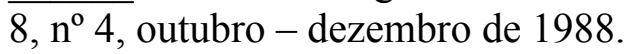

BUITONI, Ademir. Moeda, Inflação e Planos de Estabilização Econômica no Brasil. Revista dos Tribunais, vol. 713, ano 84, mar. 1995.

CALDEIRA, Jorge. Mauá. Empresário do império. São Paulo: Companhia das Letras, 1995.

CAMINHA, Maria do Carmo P. A questão da soberania e da supranacionalidade na comunidade européia e no Mercosul. Revista de Derecho del Mercosur / Doctrina Internacional y Comparada. no 6, dic. 1999.

CARVALHO, Carlos Eduardo F. As origens e a gênese do Plano Collor. Nova economia. Belo Horizonte, vol. 1, n 16, jan./abr. 2006.

Bloqueio da liquidez e estabilização: o fracasso do plano Collor. Tese de doutorado, Campinas, Unicamp, Instituto de Economia, 1996.

. O fracasso do plano Collor: erros de execução ou de concepção? Economia.

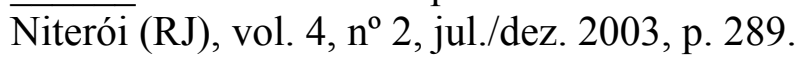
$\overline{n^{\circ} 1(17), 2000 .}$

O plano Collor no debate econômico brasileiro. Pesquisa \& Debate, volume 11, CASELLA, Paulo Borba. A integração econômica e seu tratado constitucional. In: Mercosul: desafios a vencer, vários autores. São Paulo: CBRI, 1994.

CHELALA, Charles. Política cambial e mercado de moedas na virada do século. Movendo Idéias, Belém, vol. 5, n . 8, dez. 2000. 
CONCEIÇÃO, Octavio Augusto Camargo (Coord). Reavaliando os objetivos e os resultados do plano real. Análise, Porto Alegre, vol. 16, no 2, p. 285-300, ago./dez. 2005.

COOPER, Richard N. Economic interdependence and coordination of economic policies. R. W. Jones \& P. B. Kenen (ed.) Handbook of International Economics, , chapter 23, 1985.

CORAZZA, Gentil. O banco central do Brasil: evolução histórica e institucional. São Leopoldo: Revista Perspectiva Econômica. vol. 2, nº 1, jan.-jun. 2006.

CORTEZ, Tiago Machado. Moeda, Estado e Direito. O papel do Estado na ordem monetária e seu controle. São Paulo: EDUSP, 2004. Tese (Doutorado) - Programa de PósGraduação em Direito Econômico e Financeiro, Faculdade de Direito da Universidade de São Paulo, São Paulo, 2004.

COSTA NETO, Yttrio Corrêa. Bancos oficiais no Brasil: origem e aspectos de seu desenvolvimento. Brasília: Banco Central do Brasil, 2004.

CUNHA, Paulo de Pitta e. Monetary Union and Differentiation. The External Dimension. In: Revista da Faculdade de Direito da Universidade de Lisboa, Coimbra Editora, Coimbra, 1997.

CURRIE, David, and others. International cooperation and reputation in an empirical two-bloc model. Ralph C. Bryant and Richard Portes, eds., Global Macroeconomics: policy conflict and cooperation. London: Macmillan, 1987.

CURRO, Raul Jorge de Pinho. O Mercosul e o mercado de câmbio. Dissertação de mestrado, Faculdade de Direito da Universidade de São Paulo, 2004.

D'ANGELIS, Wagner Rocha. Mercosul. Da intergovernabilidade à supranacionalidade? - Perspectivas jurídicas para a efetivação do mercado comum. Curitiba: Juruá, 2000.

DALLARI, Pedro Bohomoletz de Abreu. Constituição e tratados internacionais. São Paulo: Saraiva, 2003.

O Mercosul perante o Sistema Constitucional Brasileiro. In: BASSO, Maristela (org.). Mercosul - Mercosur: Estudos em Homenagem a Fernando Henrique Cardoso. São Paulo: Ed. Atlas, 2007. 
DE CHIARA, José Tadeu. Moeda e ordem jurídica. Tese de doutorado apresentada à Faculdade de Direito da Universidade de São Paulo, São Paulo, 1986.

DE LUCCA, Newton. Processos comunitários de integração econômica e a proteção dos consumidores. Revista de Direito do Consumidor. São Paulo: Revista dos Tribunais, $\mathrm{n}^{\circ}$ 6, out./dez. 1995.

DINH, Nguyen Quoc; DAILLIER, Patrick; PELLET, Alain. Direito internacional público. Tradução do original intitulado Droit international public. 7. édition. Lisboa: Fundação Calouste Gulbenkian, 2003.

Editoriais: Mercosul Congelado. Folha de São Paulo, São Paulo, 11 de outubro de 2001, Caderno A2.

EU Watch. A Short History of Single Currencies. A Publication of The Independence/Democracy Group. Issue 3, Oct./Nov. 2006.

FARIA, Fábio Martins. A Defesa Comercial: Origens e Regulamentação das Medidas Antidumping, Compensatórias e de Salvaguardas. São Paulo: Aduaneiras, 2003.

FAUSTO, Boris. História do Brasil. 12. edição. São Paulo: Universidade de São Paulo, 2004.

FAVARETTO, Isolde. Releitura do intervencionismo estatal no sistema financeiro nacional. In: Direito \& Justiça, ano XXVII, vol. 31, nº 2, p. 109-153, 2005.

FERRARI FILHO, Fernando. O legado do Plano Real: uma estabilização sem crescimento econômico? Revista Análise Econômica da Faculdade de Ciências Econômicas. 35. ed., Porto Alegre, ano 19, mar. 2001.

FERRAZ JÚNIOR, Tercio Sampaio; MAGLIANO FILHO, Raymundo. A bolsa de valores como sistema de poder. Revista de Direito Econômico, nº 14, maio/agos. 1980.

FIGUEIREDO FILHO, João. Políticas Monetária, Cambial e Bancária no Brasil sob a gestão do Conselho da Sumoc de 1945 a 1955. Dissertação de Mestrado em Economia. Niterói: Universidade Federal Fluminense, 2005.

FLOH, Fabio. Direito Derivado do Mercosul: Natureza Jurídica e Integração aos Ordenamentos Jurídicos Internos. In: BASSO, Maristela (org.). Mercosul - Mercosur: Estudos em homenagem a Fernando Henrique Cardoso. São Paulo: Atlas, 2007. 
FONSECA, João Bosco L. Direito econômico. 2. ed. Rio de Janeiro: Forense, 1997.

FONTOURA, Jorge. Solução de controvérsias e efetividade jurídica: as perspectivas do Mercosul. Revista do Senado Federal. Brasília, a. 33, nº 130, 1998.

FRADERA, Véra M. Jacob. Harmonização do Direito Público (constitucional) no Âmbito do Mercosul. Revista da Escola Superior da Magistratura do Estado de Santa Catarina, 1998.

FRANCO, Bernardo de Souza. Os bancos do Brasil. (primeira edição de 1848). Brasília: Editora da Universidade de Brasília.

FREITAS JUNIOR, Antonio Rodrigues. Globalização, Mercosul e crise do EstadoNação: perspectivas para o direito numa sociedade em mudança. São Paulo: LTr, 1997.

FRIEDMAN, Milton. Capitalism and Freedom. Chicago: University of Chicago Press. 2002.

GAROFALO FILHO, Emilio. Dicionário de comércio exterior e câmbio. São Paulo: Saraiva, 2004.

GIAMBIAGI, Fábio. A Moeda Comum como Base do Crescimento do Brasil e da Argentina. Ensaios BNDES, n ${ }^{\circ}$ 13, Rio de Janeiro, nov. 2001.

A Moeda Comum como Base do Crescimento do Brasil e da Argentina. Revista do Bndes, Rio de Janeiro, vol. 8, nº 16, p. 119-166, dez. 2001.

. Mercosul. O Estado de São Paulo, São Paulo, 2 de junho de 1997, p. B-12.

Mercosul: a unificação monetária faz sentido? Política Externa, Revista Paz e Terra, São Paulo, vol. 8, n 3, dez./jan./fev. 2000.

. Mercosul: Por Que a Unificação Monetária faz Sentido a Longo Prazo? Ensaios BNDES, no 12, Rio de Janeiro, dez. 1999.

- Moeda única do Mercosul. Revista Brasileira de Política Internacional. Brasília: Instituto Brasileiro de Relações Internacionais, 1998. 
. Uma proposta de unificação monetária dos países do Mercosul. Ensaios BNDES, $\overline{n^{\circ}} 4$, Rio de Janeiro.

GIAMBIAGI, Fabio; RIGOLON, Francisco José Zagari. A Economia Brasileira: Panorama Geral. BNDES, Estudos BNDES, nº. 8, 1999.

F. Áreas Monetárias Ótimas: Teoria, Unificação Monetária Européia e Aplicação para o Mercosul. BNDES, Ensaio BNDES, nº 8, 1998.

GOMES, Eduardo Biacchi. A adoção do instituto da supranacionalidade no Mercosul. Revista da Faculdade de Direito da UFPR, vol. 35, Curitiba, 2001.

Blocos econômicos e solução de controvérsias. 2. ed. Curitiba: Juruá, 2008.

GONZÁLEZ CRAVINO, S. Globalización, integración y cohesión social: el caso Mercosur. Revista de Derecho del Mercosur, $\mathrm{n}^{\mathrm{o}}$ 1, fev., 2000.

GOODHART, Charles. The approach to EMU. Making EMU happen problems and proposals: a symposium. New Jersey: International Finance Sector, Princeton University, p. 30-39, Aug. 1996 (Essay in International Finance $n^{0} 199$ ).

GREMAUD, Amaury Patrick; VASCONCELLOS, Marco Antonio Sandoval de; TONETO JR., Rudinei. Economia Brasileira Contemporânea. 4. ed. São Paulo: Atlas, 2002 .

GREMAUD, Amaury Patyrick; et al. Manual de economia. 4. edição. São Paulo: Saraiva, 2004.

GROS, Daniel. Linking the ins and outs. Making EMU happen problems and proposals: a symposium. New Jersey: International Finance Section, (Essay in International Finance no 199), Princeton University, p. 40-49. Aug. 1996.

HAWKINS, J.; MASSON, P. Regional Currency Areas and the use of Foreign Currencies. BIS paper, $n^{\circ} 17$, maio 2003.

HELLEINER, E. States and the reemergence of global finance: from Bretton Woods to the 1990's. Ithaca e Londres: Cornell University Press, 1994.

HOLANDA, Sérgio. A época colonial: do descobrimento à expansão territorial. Rio de Janeiro: Bertrand Brasil, 2000. 
HOLANDA, Sérgio Buarque de (Org.). O Brasil monárquico: o processo de emancipação. Rio de Janeiro: Bertrand Brasil, 2001.

HUGON, Paul. A moeda: introdução à análise e às políticas monetárias e à moeda no Brasil. São Paulo: Pioneiras/Edusp, 1967;

Evolução monetária da independência até a reforma monetária de 1846. São Paulo: Pioneiras/Edusp, 1972.

HUISMAN, Denis. Dicionário dos filósofos. São Paulo: Martins Fontes, 2001.

JANSEN, Letácio. A esquizofrenia monetária: Pequena história jurídica do mil réis. Revista Forense, vol. 381, 2005.

384.

A retórica do Mercosul e a moeda única regional. Revista Forense, vol. 354, p.

JELLINEK, Georg. Teoria General Del Estado. Cidade do México. Fundo de Cultura Econômica. 2002.

KENEN, P. The Theory of Optimum Currency Areas: An Ecletic View. Mundell e Swoboda, Monetary Problems of the International Evidence, Discussion Paper 2295. Londres: Centre for Economic Policy Research, 1969.

KEYNES, John Maynard. A treatise on money. Vol. I. Londres: MacMillan and Co., 1950.

. General theory of employment, interest and money. Londres: MacMillan, $\overline{1977 .}$ Original, 1936.

KNOLL DE BERTOLOTTI, Silvina Barón. Órganos de administración y gobierno del Mercosur. Buenos Aires: Depalma, 1997.

LAMPREIA, Luis Felipe apud ALISKI, Ayr. É cedo para o Mercosul ter moeda única. Zero Hora. Porto Alegre, 31 ago. 1998.

LECH, Marcelo; MOREIRA, Luiz Carlos. A Política Externa e de Segurança Comum da União Européia. Canoas: Editora da ULBRA, 2004. 
. Associação entre Mercosul e união européia: realidade ou utopia? Canoas: Editora da ULBRA, 2006.

LISSA, Violo Ídolo. Catálogo do papel - moeda do Brasil 1771- 1986. Brasília: Gráfica Brasiliana Ltda., 1987.

LOBO, Maria Teresa de C. O direito da integração nas constituições dos Estados-partes do Mercosul. a Constituição do Brasil. Revista de Derecho del Mercosur, $n^{\circ}$ 2, abril de 1999.

LOPES, João do Carmo; ROSSETTI, José pascoal. Economia Monetária. 7. ed. São Paulo: Atlas, 1998.

LUZ, Rodrigo. Relações econômicas internacionais. São Paulo: Campus, 2005.

MACEDO, Jorge. Portugal e a união monetária européia. Análise Social, vol. XXXI, (138), 1996.

MACHADO, Maria. Rui Barbosa: pensamento e ação. Rio de Janeiro: Fundação Rui Barbosa, 2002.

MAGALHÃES. José Carlos de. Guichê único europeu como referencial. In DEBATES: A defesa da concorrência no Mercosul. Seminário realizado em 2 de agosto de 1996, na sede da FIESP. São Paulo: Master's Gráfica e Editora Ltda., 1997.

MALISKA, Marcos Augusto. A supranacionalidade no Mercosul: a transferência de direitos de soberania e o problema da legitimidade democrática. Cadernos da Escola de Direito e Relações Internacionais da UniBrasil, vol. 5, jan./dez. 2005.

MALYNES, Gerrard. A treatise of the canker of England's common wealth, London, edição fac-símile, 1601.

MAUÁ, Visconde de. Autobiografia. 3. ed. Rio de Janeiro: Topbooks, 1998.

MCKINNON, R. Optimum Currency Areas. American Economic Review, Sep. 1963.

MCTEER, Bob. David Hume Foundations of the Classical School of Economics. Economic Insights. Federal Reserve Bank of Dallas, vol. 8, $\mathrm{n}^{\circ} 1$. 
MCTEER, Bob. David Ricardo Theory of Free International Trade. Economic Insights. Federal Reserve Bank Of Dallas, vol. 9, $\mathrm{n}^{\circ} 2$.

MEDINA OSÓRIO, Fábio. Direito Administrativo Sancionador. 2. edição. São Paulo: Revista dos Tribunais, 2006.

MELLO, Celso D. Albuquerque. Direito Internacional da Integração. Rio de Janeiro, Renovar, 1996.

MENDES, Antonio; NASCIMENTO, Edson Bueno. Estudo de Direito Monetário: a moeda e suas funções; obrigações monetárias; estipulação e indexação de obrigações monetárias. Revista da Procuradoria Geral do Estado de São Paulo, São Paulo, jun. 1991.

MENDES, Lívia. Do padrão ouro a Bretton Woods: algumas considerações. Brasília: UNB, 2005.

MENGER, Karl. On the origin of money. In: The economic journal, vol. $2, \mathrm{n}^{\mathrm{o}} 6$, June, 1982.

MISHKIN, Frederic S. Moedas, bancos e mercados financeiros. 5. ed. Trad. STUART, Christine Pinto Ferreira. Rio de Janeiro: LTC, 2000.

MISSELDEN, Edward. Free trade or the meanes to make trade flourish, London, edição fac-símile, 1622.

MONTEIRO, Rogério. O Sistema Financeiro do Mercosul: Mercosur - Lições do período de transitoriedade. São Paulo: Celso Bastos, 1998.

MUNDELL, R. A Theory of Optimum Currency Areas. American Economic Review, setembro de 1961.

The international monetary system in the 21st century: could gold make a comeback? Lecture delivered at St. Vincent College, Letrobe, Pennsylvania, March 12, 1997.

NASSER, Rabih Ali. A OMC e os países em desenvolvimento. São Paulo: Aduaneiras, 2002, p. 76 apud WORLD TRADE ORGANISATION. International trade statistics 2000. Geneva, 2000.

NOVELLI, José Marcos Nayme. As teorias sociológicas da inflação e o Plano Real: conflito e coalizão. Revista Política \& Sociedade, nº 6, abr. 2005. 
NUNES, Antônio. Algumas Incidências Constitucionais da Institucionalização da União Econômica e Monetária. Revista da Faculdade de Direito da UFPR, América do Sul, vol. 40, 2004.

NUSDEO, Fábio. Curso de economia. Introdução ao direito econômico. 2. ed. São Paulo: Revista dos Tribunais, 2000.

NUSSBAUM, Arthur. Money in the law national and international. A comparative study in the Borderline of law and economics. Brooklyn: The Foundation Press, 1950.

OLIVEIRA, Marcos. Moeda, juros e instituições financeiras: regime jurídico. Rio de Janeiro: Forense, 2006.

PALLARES, Jacinto. El bimetalismo. Foro de México. nº 30, $1^{\text {o }}$ set. 1955.

PASSARINHO, Jarbas. Governos e choques ideológicos. O Estado de São Paulo, São Paulo, terça- feira, 8 de janeiro de 2008, Espaço Aberto, p. A2.

PASTORE, Affonso Celso e PINOTTI, Maria Cristina. Política Econômica, Vulnerabilidade Externa e Crescimento. O Brasil e o Mundo no Limiar do Novo Século. Rio de Janeiro: José Olympio, 1998.

PEÑA, Félix. Direito e Instituições no Mercosul: um balanço de conquistas e insuficiências. In: Mercosul e União Européia: perspectivas da integração regional. Rio de Janeiro: Lumen Juris, 2006.

. Direito e instituições no Mercosul: um balanço de conquistas e insuficiências. In: AMBOS, Kai; PEREIRA, Ana Cristina.(Coord.) Mercosul e união européia: perspectivas da integração regional. Rio de Janeiro: Lumen Juris, 2006.

. Instituciones y concertación de intereses nacionales: algunas reflexiones em torno a la experiência de los primeros quince años del Mercosur. In BASSO, Maristela (org.). Mercosul - Mercosur: estudos em homenagem a Fernando Henrique Cardoso. São Paulo: Atlas, 2007.

PEROTTI, Alejandro D. La Supranacionalidad desde la óptica del Derecho Constitucional de los Estados Partes del Mercosur: el caso Brasil. Revista de Derecho del MERCOSUR, $\mathrm{n}^{\mathrm{o}}$ 6, dic. 1998. 
PINHO, Diva Benevides. Euro versus Dólar...E o Real? São Paulo: Informações Fipe, 221, 1999.

PRATES, Daniela. As assimetrias do sistema monetário e financeiro internacional. Revista Economia Contemporânea, Rio de Janeiro: maio/ago 2005.

RANGEL, Vicente Marotta. Os sujeitos de Direito Internacional. In: Direito Internacional Público. Rio de Janeiro: Escola de Guerra Naval, 1974.

RANZANI, Katia Maria. As barreiras constitucionais do Brasil para a harmonização da legislação tributária no Mercosul. Revista Jurídica da Universidade de Franca, Franca, vol. $3, \mathrm{n}^{\mathrm{o}} 4$, maio 2000 .

RATTI, Bruno. Comércio internacional e câmbio. São Paulo: Aduaneiras, 2006.

RIBEIRO, Maria de Fátima. O Euro e as perspectivas de implantação de uma moeda única no Mercosul. Revista de Direito Constitucional e Internacional, vol. 31. São Paulo: Revista dos Tribunais, 2000.

ROBERTSON, Sir Dennis. A moeda. 3. ed. Rio de Janeiro: Zahar, 1969.

ROCHA, Carmen Lúcia Antunes. Constituição, soberania e Mercosul. Revista de Informação Legislativa, no 139, jul./set. 1998.

ROCHA, Maria da Conceição Ramos. Mercosul - alcances da união aduaneira no ordenamento jurídico brasileiro. Rio de Janeiro: Lúmen Júris, 1999.

ROMMINGER, Alfredo. O Grupo Banco Mundial: origem, funcionamento e a influência do desenvolvimento sustentável em suas políticas. Universitas - Relações Int., Brasília, vol. 2, no 1, p. 269-288, jan./jun. 2004.

ROSE, A.; ENGEL, Charles. Currency unions and international integration”, Journal of Money, Credit and Banking. Vol. 34, nº 4, Nov. 2002.

SABBATO, Luiz Roberto. O Mercosul e o Direito comunitário. Revista de Derecho del Mercosur, n²Buenos Aires : La Ley, 1999.

SACHS, Jeffrey; ZINI JR., Álvaro. A inflação brasileira e o "plano real". Revista de Economia Política, vol. 15, nº 2 (58), abr./ jun. 1995. 
SALVATORE, Dominick. Economia Internacional. 6. ed. Rio de Janeiro: LTC Editora S.A., 2000.

SALVATORE, Dominick. The common unresolved problem with the EMS and EMU. American Economic Review Nashville: American Economic Association, vol. 86, $\mathrm{n}^{\circ}$ 02, may 1997.

SANDRONI, Paulo. Novíssimo dicionário de economia. 11. ed. São Paulo: Best Seller, 2003.

SANT'ANA, José Antonio. Economia monetária: a moeda em uma economia globalizada. Brasília: Universidade de Brasília, 1997.

SARAIVA, José Hermano. História concisa de Portugal. 20. ed. Portugal: Publicações Europa-Amércia, 1999.

SILVA, Aníbal Cavaco. Portugal e a moeda única. Lisboa: Verbo, 1998.

SILVA NETO, O.C; MELO, S.S. Solução de Controvérsias do Mercosul. RODRIGUES, Horácio Wanderlei ( Coord.), Cap. IV - "considerações sobre a cooperação jurisdicional no âmbito do Mercosul", 1997.

SIMONSEN, Mário Henrique. Inflação: gradualismo x tratamento de choque. Rio de Janeiro: Apec, 1970.

SMITH, Adam. Riqueza das nações. Rio de Janeiro: Ediouro, 1986.

SOUZA, Carlos Inglez. A anarquia monetária e suas conseqüências. São Paulo: Cia. Monteiro Lobato, 1924.

SPAVENTA, Luigi. Coexisting with the euro: prospects and risks after Verona. Making EMU happen problems and proposals: a symposium. New Jersey: International Finance Section, (Essay in International Finance $\mathrm{n}^{\mathrm{o}}$ 199), Princeton University, p. 50-63. Aug. 1996.

SUTHERLAND, Peter. Em defesa da união monetária européia. Foreign Affairs, edição brasileira, jan. 1997.

THÉRET, Bruno. Os três estados da moeda. Abordagem interdisciplinar do fato monetário economia e sociedade, Campinas, vol. 17, $\mathrm{n}^{\mathrm{o}} 1$ (32), abr. 2008. 
TITIEV, Misha. Introdução à antropologia cultural. 8. ed., Fundação Calouste Gulbenkian, p. 134-137 e Reed, Charles in "The Origins of Agriculture".

TONETO JR., Rudinei. Economia Brasileira Contemporânea. 4. ed. São Paulo: Atlas, 2002.

TORRES, Francisco. Portugal towards economic and monetary union: a political economy perspective. In: JONES, Erik; FRIEDEN, Jeffry; TORRES, Francico. Joing Europe's Monetary Club: the challenges for Smaller member state. Nova Iorque: St. Martin's Press. 1998.

TRICHES, Divanildo. Economia Política do Mercosul e aspectos monetários, cambiais e o Euro em perspectiva. Caxias do Sul: Educs, 2003.

TURSI, Antonio D. La idea de representación en la obra política de Nicolas de Oresme. Veritas. Porto Alegre, vol. 43, nº 3, set. 1998.

VENTURA, Deisy. As Assimetrias entre o Mercosul e a União Européia: os desafios de uma associação inter-regional. São Paulo: Manole, 2003.

VERÇOSA, Haroldo Malheiros Duclerc. Bancos Centrais no Direito Comparado - O Sistema Financeiro Nacional e o Banco Central do Brasil (o regime vigente e as propostas de reformulação), São Paulo: Malheiros, 2005.

VIDIGAL, Geraldo de Camargo. Disciplina dos órgãos de direção monetária. São Paulo, 1964.

YAMAMOTO, Toru. Direito Internacional e Direito Interno. São Paulo: Editora Sérgio Antônio Fabbris (SAFE), 2000.

WEATHERFORD, J. McIver. The history of money. New York: Three Rivers Press, 1997.

WEBER, Max. Economía y sociedad. Esbozo de sociologia comprensiva. México: Fondo de Cultura Econômica, 1994.

WYPLOSZ, Charles. EMU: Why and how it might happen. Journal of Economic Perspectives, Nashville: American Economic Association, vol. 11, n 04, p. 03-22, fall 1997. 


\section{Endereços Eletrônicos}

A União Econômica e Monetária (UEM) e o Euro. In: A União Européia em 12 Lições. Disponível em: <http://europa.eu/abc/12lessons/lesson_7/index_pt.htm>. Acesso em: 2 dez. 2008.

Actividades da União Européia: síntese da lesgislação. A construção européia através dos tratados: Tratado que institui a Comunidade Económica Europeia ou CEE. Disponível em: $<$ http://europa.eu/scadplus/treaties/eec_pt.htm>. Acesso em: 19 jan. 2008.

Adesão da Eslovênia ao euro (2007). Disponível em:

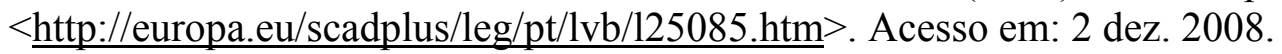

ARAÚJO, Erilton; DONHA, Talita. Discricionariedade na política monetária brasileira após o plano real: um teste baseado na correlação de longo prazo entre inflação e produto. IBMEC WORKING PAPER - WPE - 61 - 2008. Disponível em: $<$ www.ibmecsp.edu.br/pesquisa/download.php?recid=3166>. Acesso em: 26 nov. 2008, p. 2

Aspectos Práticos da Introdução do Euro. Disponível em: $<$ http://europa.eu/scadplus/leg/pt/s01001.htm> . Acesso em: 2 dez. 2008.

AURÉLIO. Dicionário da Língua Portuguesa. Disponível em: $<$ http://houaiss.uol.com.br/busca.jhtm?verbete=encilhamento\&stype $=\mathrm{k}>$. Acesso em: 2 maio 2008.

Banco Central do Brasil. Disponível em: $<$ http://www.bcb.gov.br/?REFSISMON $>$. Acesso em: 2 maio 2007.

Banco Central Europeu (BCE). 23 maio 2007. Disponível em: $<$ http://europa.eu/scadplus/leg/pt/lvb/o10001.htm>. Acesso em: 11 dez. 2008.

BARBOSA, Salomão Almeida. As Relações Internacionais na Constituição da Argentina, Revista de Doutrina TRF 4 ${ }^{\mathrm{a}}$ Região, agosto de 2004. Disponível em: $<$ http://www.revistadoutrina.trf4.jus.br >. Acesso em: 24 nov. 2008.

BAUMANN, Renato; MUSSI, Carlos. Mercosul: então e agora? LC/BRS/R.159, maio 2006, p. 2. Disponível em: <http://www. ciu.com.uy>. Acesso em: 24 nov. 2008. 
BRESSER-PEREIRA, Luiz Carlos. Plano de controle macroeconômico. Brasília, 21 jul. 1987, p. 8. Disponível em: <http://www.bresserpereira.org.br/Documents/MFazenda>. Acesso em: 25 nov. 2008.

CASA DA MOEDA DO BRASIL < http://www.casadamoeda.gov.br>. Acesso em: 22 de nov. 2008.

Código de Redação Interinstitucional. Disponível em: $<$ http://publications.europa.eu/code/pt/pt-370300.htm>. Acesso em: $1^{\mathrm{o}} \mathrm{dez} .2008$.

CONSTITUCIÓN DE LA REPÚBLICA. Disponível em: $<$ http://www.parlamento.gub.uy/constituciones/const004.htm $>$. Acesso em: 25 nov. 2008.

Dinamarca: cláusula de exención de la UEM. 16.8.2006. Disponível em: $<$ http://www.europa.eu $>$. Acesso em: 29 nov. 2008.

EICHENGREEN, Barry. Are there parallels between EMU and similar historical experiences? $\quad 14 \quad$ January 2008.2 Disponível em: <http://www.voxeu.org/index.php?q=node/869>. Acesso em: 2 dez. 2008.

EUROPA. Rumo à moeda única: síntese histórica da UEM. 22 fev. .2007. Disponível em: $<$ http://europa.eu/scadplus/leg/pt/lvb/125007.htm>. Acesso em: 12 dez. 2008.

EU4JOURNALISTS - Direção Geral de Comunicação da Comissão da União Européia. A União Económica e Monetária e o Euro. Disponível em: $<\underline{\mathrm{http}} / / /$ www.eu4journalists.eu/ index.php/dossiers/portuguese/C23>. Acesso em: 3 dez. 2008.

"Fatos e Números Essenciais sobre a Europa e os Europeus". Disponível em: $<$ http://www.europa.eu $>$. Acesso em: 2 dez. 2008.

FONTOURA, Jorge. O Avanço Constitucional Argentino e o Mercosul. Revista de Informação Legislativa, Brasília, a. 37 no 146 abr./jun. 2000, p. 56. Disponível em: $<$ http://www.senado.gov.br/web/cegraf/ril/Pdf/pdf_146/r146-04.pdf $>$. Acesso em: 24 nov. 2008.

GIRON, Alicia. Moneda, poder y sociedad. Disponível em: <http://es.pekea-fr.org/srmx/Giron.pdf>. Acesso em: 5 dez. 2008, p. 9.

GUIMARÃES ROCHA, Recanto das Letras. Disponível em: $<$ http://recantodasletras.uol.com.br/biografias/130166> . Acesso em: 10 jan. 2009 
HAZLITT, Henry. Understanding "Austrian" economics. Ideas on Liberty. October, 2003, p. 33. Disponível em: < http://www.fee.org/pdf/the-freeman/hazlitt1003.pdf>. Acesso em: 6 dez. 2008.

HOUAISS. Dicionário da Língua Portuguesa. Disponível em: $<$ http://houaiss.uol.com.br/busca.jhtm?verbete=encilhamento\&stype=k $>$. Acesso em: $2 \mathrm{de}$ maio de 2008.

Introdução do euro: critérios de convergência. 20/06/2006 Disponível em: $<\underline{\text { http://www.europa.eu }}>$. Acesso em: 29 nov. 2008.

IPEADATA. Disponível em: <http://www.ipeadata.gov.br $>$. Acesso em: 26 de novembro de 2008.

KAMINSKI, N.; MAUCH Palmeira, E.. A política econômica e o sistema monetário. In: Observatorio de la Economía Latinoamericana, $\mathrm{n}^{\circ}$ 85, 2007. Disponível em: $<$ http://www.eumed.net/cursecon/ecolat/br/>. Acesso em: 4 dez. 2008.

KRUGMAN P. Beware of the Euro: you may get what you want. 1998. Disponível em: $<$ http://web.mit.edu/krugman/www $>$. Acesso em: 10 de janeiro de 2007.

LAGO, Luiz Aranha Corrêa do. A moeda metálica em perspectiva histórica: notas em torno de uma exposição. Departamento de Economia - PUC, 2004, p. 6 Disponível em: $<$ http://www.econ.puc-rio.br/pdf/td481.pdf>. Acesso em: 4 dez. 2008.

LAGO, Luiz Aranha Corrêa do. A moeda metálica em perspectiva histórica: notas em torno de uma exposição. Departamento de Economia - PUC, 2004. p. 6. Disponível em: $<$ http://www.econ.puc-rio.br/pdf/td481.pdf $>$. Acesso em: 04 de dezembro de 2008.

LATIN DICTIONARY AND GRAMMAR AID. University of Notre Dame. Disponível em: $<$ http://www.archives.nd.edu/cgi-bin/lookit.pl?latin=pecus $>$. Acesso em: 6 dez. 2008.

MARTINEZ, Francisco. El sistema monetário mexicano, p. 188. Disponível em: $<$ http://www.juridicas.unam.mx/publica/librev/rev/jurid/cont/16/pr/pr13.pdf $>$. Acesso em: 5 dez. 2008.

MENDES, Norma Musco. Império e Romanização: 'Estratégias', Dominação e Colapso. Brathair 7 (1), 2007, p. 30. Disponível em: <http://www.brathair.com>. Acesso em: 2 dez. 2008 . 
MOTTA, João Ricardo da. Trajetória do plano real. Nota Técnica/Câmara dos Deputados, jul. 2008, p. 4. Disponível em: $<$ http://apache.camara.gov.br/portal/arquivos/Camara/internet/publicacoes $>$. Acesso em: 27 nov. 2008.

O Futuro da Europa. Instituto de Estudos Estratégicos e Internacionais, $\mathrm{n}^{\mathrm{o}} 3$, mar./abr. de 2007. p. 4. Disponível em: <http://www.ieei.pt/files/070326_boletim_versao2.pdf $>$. Acesso em: 3 dez. 2008.

Protocolo de Ouro Preto - Protocolo Adicional ao Tratado de Assunção sobre a Estrutura Institucional do Mercosul. Disponível em: <http:www.mercosur.int>. Acesso em: 23 nov. 2008 .

Reino Unido: cláusula de exención de la UEM 30.6.2006. Disponível em:

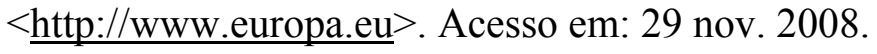

Reunião dos Presidentes dos Estados Partes do Mercosul, em Florianópolis, em 15 dez. 2000. Disponível em: <http://gmm.mecon.gov.ar/pdf/declaracion_presidencial_metasdic2000(por).pdf>. Acesso em: 14 dez. 2008.

Senhoriagem e financiamento do setor público no Brasil. Disponível em: $<$ http://www.tesouro.fazenda.gov.br/

Premio_TN/XIPremio/divida/MHafdpXIPTN/mh_premio_afdp.pdf $>$. Acesso em: 12 nov. 2008.

SCHEINER, Andrei. História da moeda. Textos, Artigos e Análises. Disponível em: $<$ http:// www.bancocentral.gov.br.htm>. Acesso em: 03 de dezembro de 2008.

SILVA, Antonio Carlos da. O (des)ajuste global e os princípios da nova ordem econômica: o Brasil na Era dos Extremos. Revista Gestão \& Planejamento (G\&P). Vol. 1, $\mathrm{n}^{\circ}$ 14, 1999. Disponível em: <http://www.revistas.unifacs.br/index.php/rgb/article/ viewFile/128/128 $>$. Acesso em: 26 de novembro de 2008.

Sítio oficial do Mercosul. Disponível em: <http://www.mercosur.int>. Acesso em: 24 nov. 2008 .

Tratado para a Constituição de um mercado comum entre a República Argentina, a República Federativa do Brasil, a República do Paraguai e a República Oriental do Uruguai, disponível em <http://www.mercosur.int>. Acesso em: 21 nov. 2008. 
VERSIANO, Flávio Rabelo. Inflação e política antiinflacionária no Brasil. Brasília: Unb. Disponível em: < http://www.unb.br/face/eco/inteco/textosnet/2parte/ inflacao_e_pol_inf.pdf $>$. Acesso em: 26 de nov. 2008.

WORLD TRADE ORGANISATION. International trade statistics 2000. Geneva, 2000, p. 28.

WORLD TRADE ORGANISATION. International trade statistics 2000. Geneva, 2000. Disponível em: $<$ http://www.wto.org $>$. Acesso em: 12 de dezembro de 2007. 


\section{RESUMO}

Esta pesquisa busca debater, sob vários ângulos e pontos de vista, mas, essencialmente, enfocando o aspecto jurídico, a possibilidade ou não de se adotar uma moeda única no âmbito do Mercosul, a partir da experiência européia com o euro e das tentativas de integração, incluindo-se a análise de questões como a supranacionalidade, a intergovernabilidade, a soberania, a autonomia e independência dos bancos centrais, bem como a criação de um banco central único naquele bloco eocnômico.

São ressaltados, ainda, os conceitos de moeda única, as suas várias funções e características.

Ao mesmo tempo, é feita uma incursão histórica pelo mundo em geral, e pelo Brasil, em particular, mostrando a evolução da moeda em seus vários estágios, bem como os diversos instrumentos monetários.

Aspectos outros, como o Sistema Monetário Internacional e sua relação com o ouro e outras moedas, também foram objeto de análise.

Destaque especial, contudo, foi dado à moeda no Brasil - em especial, às reformas monetárias e aos planos econômicos -, mostrando-se, principalmente no que tange ao mercado de câmbio, as funções do Banco Central do Brasil.

Abordam-se também as diferenças entre a União Européia e o Mercosul, passando pela apreciação do importante Tratado de Maastricht. Nesse sentido, avaliam-se as dificuldades jurídicas pelas quais o primeiro bloco passou, e as que o segundo irá enfrentar, como, por exemplo, a harmonização das legislações, a imprevisão constitucional da supranacionalidade, a cláusula de compromisso democrático e a necessária segurança jurídica.

E, por fim, lança-se o debate em torno dos pressupostos e critérios para a adoção de uma moeda única no Mercosul, com uma análise crítica mais particularizada das vantagens e desvantagens, e destacando seus reflexos no comércio internacional.

Nas conclusões, refutamos os argumentos favoráveis à adoção de uma moeda única no Mercosul, a partir do entendimento fundamental de que inexistem, nem agora e nem no futuro previsível, as precondições políticas e jurídicas para a sua implantação. 


\begin{abstract}
This research seeks to discuss, under many angles and views, but essentially focusing on the juridical aspects, if there is any possibility to adopt a common currency within Mercosul from the European experience with the euro and the attempts of integration, including the analysis of issues such as the supra-nationalism, the intergovernmentalism, sovereignty, autonomy and independence of central banks, as well as the creation of a common central bank for that economic bloc.

Furthermore, the common currency concepts and its several functions and characteristics are emphasized.

At the same time, an historical incursion all over the world in general, and within Brazil, in particular, is made, by pointing out the evolution of the currency, its several stages and the various monetary instruments.

Other aspects, such as the International Monetary System and its relation with gold and other currencies, have also been subject to analysis.

However, special emphasis is given to Brazil's currency - specially to the monetary reforms and economic plans -, stressing the roles of the Brazilian Central Bank, mainly as regards the foreign exchange market.

The differences between the EU and the Mercosul are also addressed through the analysis of the important Maastricht Treaty. In this connection, it is assessed the legal problems suffered by the first block and the ones the second will still face, as, for instance, the harmonization of laws, the lack of constitutional prevision of supra-nationalism, the democratic commitment clause and the necessary legal certainty.

Finally, the discussion is launched on the prerequisites and criteria for the adoption of a common currency within Mercosul, together with a detailed critical analysis of the advantages and disadvantages, and drawing some consequences on the foreign trade.

Conclusions contest the favorable ideas to the adoption of a common currency within Mercosul, based on the fundamental understanding that no political and legal preconditions exist, either presently or in the foreknowable future, for its implantation.
\end{abstract}




\section{RÉSUMÉ}

Cette perquisition cherche débattre, sous des angles variés et de plusieurs avis, mais, essentiellement sous l'aspect juridique, la possibilité ou non de s'adopter une monnaie unique dans le cadre du Mercosud, à partir de l'expérience européenne avec l'euro et des tentatives d'integration, en ajoutant l'analyse de questions comme la supranationalité, la inter-gouvernabilité, la souveraineté, l'autonomie et l'independance des banques centrales, ainsi que la création d'une banque centrale dans ce bloc économique.

On rehausse, encore, les concepts de monnaie unique, ses plusieurs fonctions et caractéristiques.

En même temps, on fait une incursion historique par le monde en général, et par le Brésil, en particulier, en montrant l'evolution de la monnaie dans ses plusieurs stages et les divers instruments monétaires.

Des aspects autres, comme le Système Monétaire International et sa relation avec l'or et autres monnaies, ont été, également, des objets d'analyse.

Proéminence spéciale, néanmoins, a été donné à la monnaie au Brésil et, spécifiquement, aux reformes monétaires et aux plans économiques, en mettant en relief les rôles de la Banque Centrale du Brésil, surtout en ce qui concerne le marché d'échange,

S'abordent aussi les différences entre 1'Union Européenne e le Mercosud, en passant par l'analyse de l'important Traité de Maastricht. De cette façon, s'évaluent les difficultés juridiques supportées par le premier bloc, et celles-là qui seront affrontées par le second, comme, par example, l'harmonisation des législations, l'imprévision constitutionnelle de la supranationalité, la clause d'engagement démocratique et la securité juridique nécessaire.

Et, finalement, il se lance le débat autour des pré-suppositions et des critères pour l'adoption d'une monnaie unique dans le Mercosud, avec une analyse critique plus détaillée des avantages et des désavantages, et ses conséquences sur le commerce international.

Dans les conclusions, se réfutent les idées favorables à l'adoption d'une monnaie unique dans le Mercosud, à partir de l'entendement fondamental qu'il n'existent pas, ni à présent et ni au prévisible future, les preconditions politiques et juridiques pour leur implantation. 